

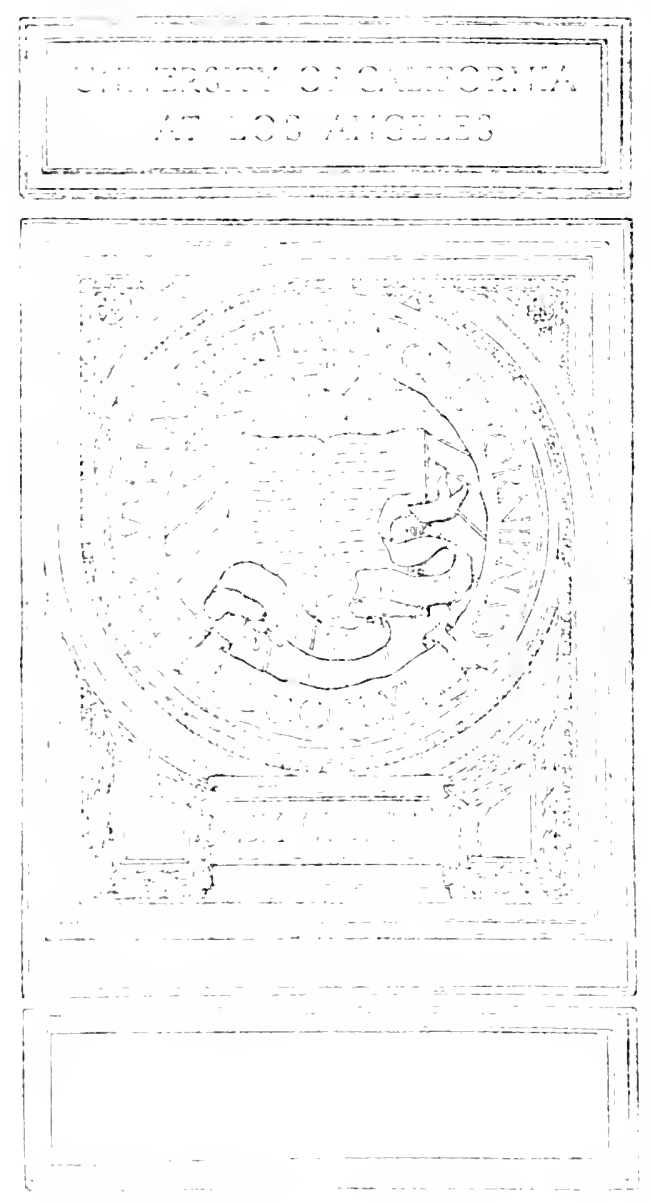




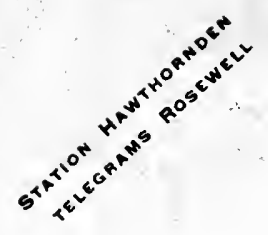

GORTON LASSWADE MIDLOTHIAN

Yo Ins. Hhent

sild bestuistes

ja limas auce it hav Rear.

C. Campóletraser.

Linas 1989. 
Digitized by the Internet Archive in 2007 with funding from Microsoft Corporation 


' 




\title{
PHILOSOPHICAL IVORKS
}

\section{BY \\ PROFESSOR CAMPBELL FRASER.}

\author{
HON. D.C.L. OXON.
}

\section{THE COLLECTEI) WORKS OF BISHOP IERKELEY.}

With Prefaces and Annotations, and an Account of his Life.

Four vols. 8vo. Revised Edition. Clarendon Press. ㄹ. 18:.

"It is highly eretitable to the Delegates of the clarenton Press to have froposerl this edition of Berkeley's Workis, and it is difticult to concelve that ideta better carried out than it has been by Professor Fraser."-Onusterly lieciew.

"At length we have a conrylete erlition of Berkeley's Works, which retherty" creditalike on the University Press of Oxford and on the University of Elintmryls." - Ealinburgh Recieu.

SELECTIONS FROM BERKELEY. With an Introduction and Notes. For the use of students in the Unjversities. One vol. crown sro. Clareudon Press. Ts. 6d.

"Of the Notes, as of the Introduction, we can safely affirm that thry reveal so mueh care and acnteness, so mehe candour and faniliarity with metaphysical speculations, and such a capaleity for presenting the most abstru-e gutestions in language which is never pedantic, hut always directly and luminouly expressive et the subject umber discussion, as to render the present volume a typieal specinem

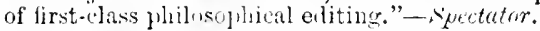

IERKELEY. "Philosophical Classics for English Realer?."

New Edition. W. Blackwood \& Sons. Crown 8vo, 1s.

"If all volumes of philosephical diassies were like this, literature wonly $\mathrm{r}$ eeive a great acouisition, and general readers a great boon." - Scotsmu.

LOCKE'S ESSAY CUNCERNING HLMAN ENIERSTANDIN(r. Annotated: with Prolegomena, biographimal, critical, and historical. Two vols. Sro. Clarendom Press. ti], 12 .

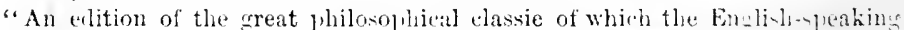
world may well let proud."-(American) Philssophical Re ciew.

LOCKE. "Philosophical Classics for English Readexs." IV. Blackword \& Sons. (Kown 8vo, ls.

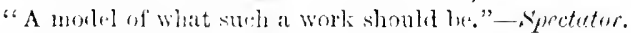

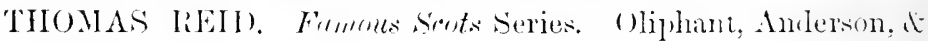
Ferrier. Fealp., 1s. (id.

"An expert's work of the lust linul."-- cincerticen.

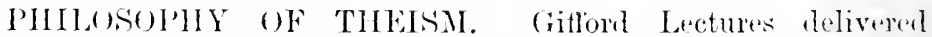
before the Univensity of Edinhmen in 1894-96. A $\mathrm{N}$. w Edition. (One: vol. demy svo. W. Blackwool \& Sons. (in. tir. sert.

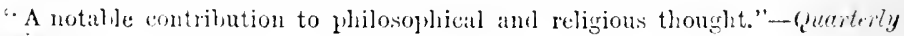
lieview. 


\section{BIOGRAPHIA PHILOSOPHICA}






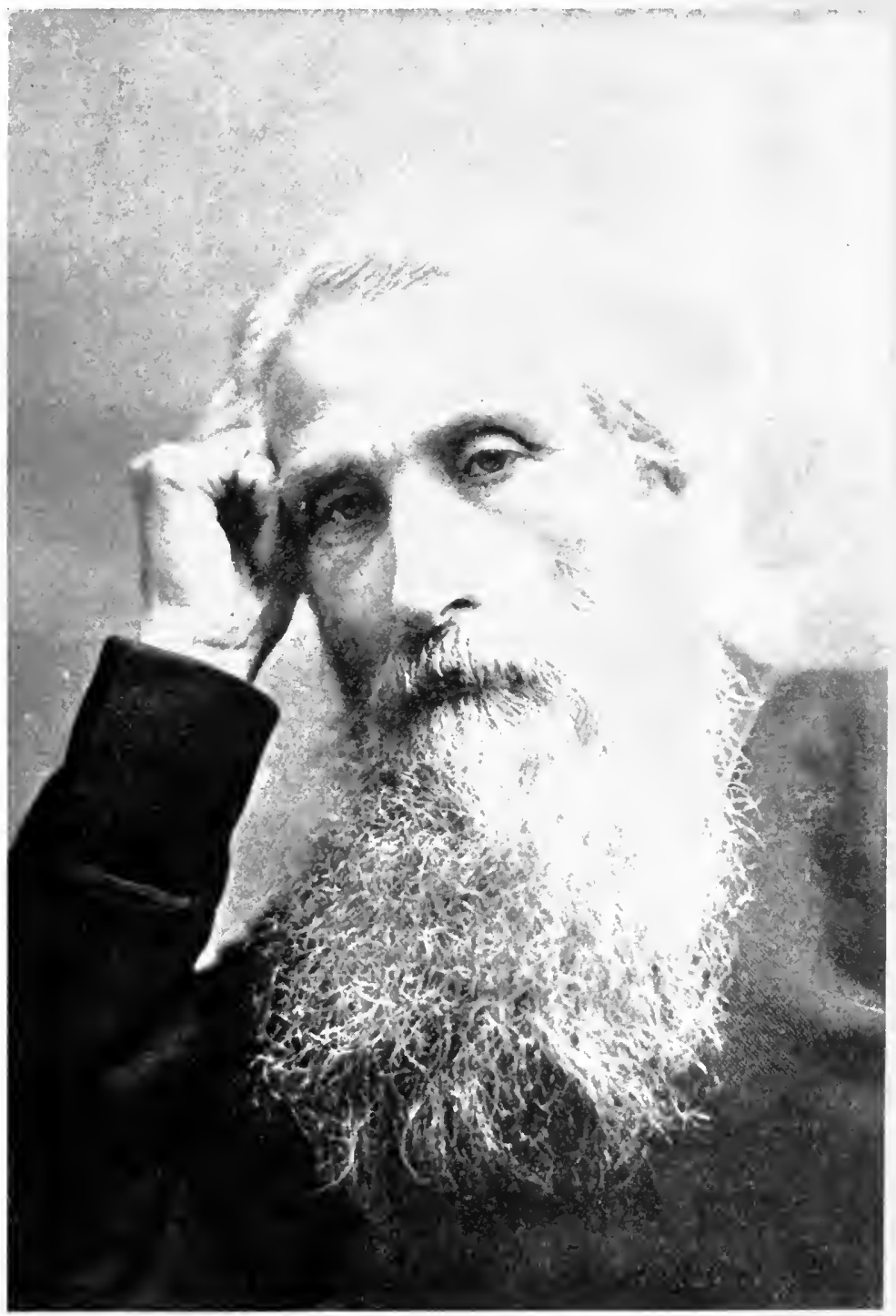

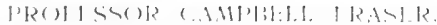




\section{BIOGRAPHIA PHILOSOPHICA}

A RETROSPECT

BY

\section{ALEXANDER CAMPBELL FRASER}

FELLOW OF THE BRITISH ACADEMY ;

HON. D.C.L. (OXFORD),

HON. LL.D. (GLASG, \& EDIN.) LITT.D. (DTBLIN);

PROFESSOR (EMERITTS) OF LOGIC AND METAPHYSICS, AND FORMERLY GIFFORD LECTCRER ON NATURAL THEOLOGY,

IN THE

UNIVERSTTY OF EDINBURGH

UT HORA, SIC VITA

SECOND EDITION

WILLIAM BLACKWOOD AND SONS

EDINBURGH AND LONDON

MCMI V 


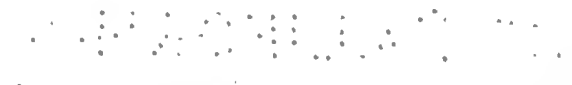

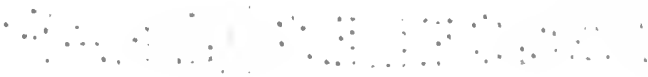




\section{$7:$}

迹

TO

\section{MY WIFE, \\ WY CONSTANT LOITNG SUPPORT}

FOR

FIFTYFOLR YEALS.

$\therefore$

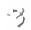

\section{3}





\section{P R E F A C E.}

IT may appear to some that in the following pages the Biographice is too prominent, to others that the Philosophice is in excess, and perhaps a larger number may think that there is too much of both.

When I remembered how the modesty of David Hume confined his narrative of the events of his own really memorable life within about a dozen pages, I was ready to agree with the first of these opinions, and to resolve that this Retrospect should remain unpublished. But I reflected that here the Biographice was introduced for the sake of Philosoplice, so that it was not a story of personal incidents for their own sake. The narrative is intended partly to infuse some familiar human interest into this account of a philosophical endeavour to deal with the riddle of the Unirerse; and partly to show how racial, educational, and social influences, as well as changing phases of thought and national sentiment, in the last eighty years of the nineteenth century, have tended to 
direct the issue of that intellectual endeavomr. Besides, as my former publications have been largely fragmentary, it seemed that their latent unity and general drift might become more apparent through a medium which, I fear after all, is too autobiographical.

The second, fourth, fifth, and eighth chapters are chiefly philosophical: the rationale of theistic faith and hope, in which the preceding chapters converge, is presented in outline in the cighth. The other chapters are more mixed. In the first and serenth I have perhaps unduly indulged in local and personal recollections which might have been multiplied to an indefinite extent. In the third chapter I was led to approach two ceclesiastical revolutions, each of commanding interest in the recent church history of Britain, and which in some respects resemble one another -the Oxford Movement, inspired by Newman, which still agitates the ancient historic Church of England, and the Edinburgh Movement, inspired by Chalmers, which conducted to ecclesiastical disruption in Scotland.

I have to thank Professor Pringle-Pattison, my successor in the Chair of Hamilton, for his kindness in reading the proofs, and for useful suggestions.

Goptos, H.wthorndex, Mreck 1904. 


\section{PREFATORY NOTE TO THE SECOND EDITION.}

I AVAIL myself of a second edition of the 'Biographia' to offer thanks for sympathetic criticism given to the philosophy of theistic faith in which it issues. According to this philosophy, commonsense experience and human science (either consciously or tacitly) presuppose a moral or religious final conception of the universe of things and persons in which we participate-with all that this conception is found by reflection to involve in its development through the ages; so that inevitable theistic faith, instead of contradicting the physical order of things, is really its reasonable foundation. How alien soever man may at present be from his divine ideal, the truth that we have our personal being in a universe eternally rooted in Active Reason or Omnipotent Goodness is thus the lesson at once of religion and philosophy.

March 1905. 



\title{
CONTENTS.
}

\author{
CHAPTER I. \\ IN THE LAND OF LORNE: EARLy MEMORIES.
}

1819-1833.

Some awakening questions in boyhood-In what, and why, am I?-Early environment at Ardchattan-Genealogical - Frasers of Strichen-Croy and Culloden-Campbells of Barcaldine and Glenure-Barcaldine Castle-Murder of my great-granduncle, Colin Campbell of Glenure, in 1752 - 'Allan Breck' and 'Kidnapped' - A metaphysical Colin Campbell of Achnaba-A centenarian at Gallanach -Ardchattan manse family - My mother and Church of England Evangelicalism-Visit to Strathnairn in 1824 -Johnson and Boswell at Cawdor manse-Miss Macaulay and her nephew "Tom"- The "Comet"-The sultry summer of 1826 - Dunollie and the lords of LorneGeneral Campbell of Lochnell-Ardchattan parish school in 1827 and Archibald MacCallum-Bishop Corrie-Sir Colquhoun Grant-My desultory education-'Edinburgh Evening Courant'-Glasgow in 1829 and the Catholic Relief Bill - Parliamentary Reform and Lord John Russell-Favourite books-Sir Walter Scott interdicted -My metaphysical aunt and John Locke-Robert Owen - Sir Guy Campbell-Ardchattan Priory and the Campbells of Ardchattan - Laurence Dundas Campbell and "Junius"-Inverawe and its legends-Bonawe and William Wordsworth - Some Lorne clergymen - John Macleod Campbell-Gaelic language and literature and the GaelThe Land of Lorne in the olden time 


\author{
CHAPTER II. \\ IN EDINBURGH: THE ENIGMA OF TIAE UNIVERSE.
}

1833-1842.

My tutor in 1833-At Glasgow College-Professors William Ramsay, Sir Daniel Sandford, and James Mylne-Edinburgh in 1836 - Professor Pillans - David Ritchie and Philosophy in 1835 - "Christopher North" - Thomas Brown on "Cause and Effect"-What is meant by "a cause"? - David Hume in intellectual perplexityBerkeley, Coleridge, and Kant--Sir William Hamilton in 1838-His select class for young metaphysicians-His reunions at 11 Manor Place-J. W. Semple and J. F. Ferrier-Theories of external Perception and of active Causation-Commencement of theological studies-Hamilton and Chalmers-Theism of Chalmers-Bishop Butler - Jonathan Elwards and Universal Necessity - What is Death? - "Obstinate questionings"_German IdealismEdinburgh College companionship-John Cairns, James Walker, and David Masson-Essay on "Toleration" in 1841 .

\title{
CILAP'TER III.
}

AN ECCLESIASTICAL DIGRESSION,

$1842-1846$.

Church History and Doctor Welsh-The Oxforth Movement and Anglo-Catholicism-The 'Record' newspaper-The Ilistoric Church-Catholic-Studies in Thumas of Aquin, Pascal, anrl Fénelon-Ecclesiastical Infallibility-Biblical Infallibility-Irooker and the Puritans-London visited in 1842-Honse of Commons-Oxford and NewmanBelgium, the Rhine, and lotterlam-Ecclesiastical war in Scotland - "Voluntaries" and national secularisation - Chalmer's on Church Establishment in divided Christ- 
endom-Ecclesiastical freedom in the national Establishment-The "Veto" Act of the Church-Viscount Melbourne-Sir William Hamilton on "Non-Intrusion" -Two Ecclesiastical Ideals in collision in Scotland-Disruption in 1843-Cramond and Arthur Collier-At Steeple Langford in 1903-Essay on "Leibniz" in 1846-Granton House-Notable persons-Patrick MacDougall-Welsh, Candlish, and Guthrie-Sir David Brewster-Hugh Miller -Lord Jeffrey-John Stuart Blackie on "a Free University"-Logic Chair in New College-Tour in France and England in 1846

\section{CHAPTER IV.}

RETURN TO PHILOSOPHY: 'NORTH BRITISH REVIEW.'

$1846-1856$.

My new environment-"A Scottish Pascal"-Jolnn Veitch, Alexander Balmain Bruce, and Alexander NicolsonHamilton's "Reid" in 1846-Chalmers, Morell, and German Pantheism-Death of Chalmers in 1847-Cambridge and Bath in 1848-Hamilton's reunions at 16 Great King Street-Doctor Logan and Lord Acton-Mill's 'Logic'Comte's 'Philosophie Positive' - Essay on Hamilton's "Reid" in 1848-Studies in Aristotle's 'Organon' and the 'Novum Organum' - Editorship of 'North British Review' in 1850-A summer in England-F. D. Maurice, Cliarles Kingsley, and A. P. Stanley-Carlyle and MillOxford and Herstmonceaux - Some North British Reviewers - Essay on Hamilton's 'Discussions' in 1852Theistic causation - Essay on 'The Insoluble Problem' in 1854-Is God in any way knowable by man?-Essay on 'Augustinianism,' or the final Destiny of Men, in 1855 -Essay on Eerrier's 'Metaphysics' in 1855- Principal William Cunningham rersus Isaac Taylor and the 'North British Review'-Scottish ecclesiastical theology in the early and the latter part of the nineteenth century-Death of Sir William Hamilton in 1856-Contest for the vacant Chair . 


\section{CHAPTER V. \\ IN THE CHAIR OF HAMILTON,}

$1856-1891$.

Cousin's advice-New phases of thought in the 'Fifties and 'Sixties-Young Scotland and old Scottish Philosolhy-Hamilton's 'Lectures' and Mansel's 'Bampton Lectures' -Hamilton's ' Cnknowable Reality' - Mansel's two Moralities - Mill cersiss Hamilton - Spencer's adaptation of Hamilton and Mansel-Spinoza, "De Deo," and Essay on Spinoza in 1863-Hegelian Theism-My Philosophical Tic Mediu-Essays on "The Real World of Berkeley" in 1862, and on his 'Divine Language of Vision' in 1864-The ultimate Spirituality and Spinitual Activity of the Universe - An Oxford Edition of Berkeley proposedHoughton Conquest-The Berkeley MSS. referred to ly Southey-Berkelcy's 'Siris' and the immanence of Jeity -Public interest in Berkeley-Logic in the Edinburgh class-room-Inference and Divine Intuition-Psychology in the class-room-Special class for Metaphysics-The young metaphysicians and their" "Philosophical Society"

\section{CHAP'TER VT.}

THE UNIVERSITY OF EDINBURGH.

$1859-1889$.

Scottish University Reform in 1858-The University of Edinburgh reorganised by Inglis-Its Academical Administration-Brougham and Inglis sncessively its ChancellorsGladstone and Carlyle Rectors in succession - Carlyle's Rectorial Address-Death of Principal Lee in 1859-Sir David Brewster, Principal, and his academical inspiration -Principal Sir Alexander Grant in 1868-Extraordinary development of the Iniversity and its resources nuler 
Grant-Some contemporary Professors-The "Symposium Academicum"-Founded by Principal Robertson in 1792 -Portrait of Robertson-Symposiasts and guests at Symposia-Academical Reform in 1889 under Lord Kinnear-Bacon s warning to universities . . . .

\section{CHAPTER VII.}

ACADEMICAL VACATIONS.

$1856-1890$.

Samuel Johnson and Thomas Chalmers on Scottish academical vacations and professors-Professorial authorship-Locomotion-Annual visits to London-Its local associationsHaunted houses-The Atheneum Club and its memories -The "London Metaphysical Society" in 1869-81-Names of members - Questions discussed - My last sight of Herbert Spencer-Parting visits to J. S. Mill and Thomas Carlyle-Lord and Lady Amberley--Little Eife HouseLady Stanley of Alderley-Lord John Russell at Pembroke Lodge-Emerson, the Grotes, J. A. Froude, Browning, \&c. -Isaac Taylor at Stanford Rivers-His dual personality according to Sir James Stephen-The Church and nonconformity-A curious dream-The manor-house of Oates and John Locke-C'ambridge and Whewell-A plurality of inhabited worlds?-Oxford and Lord Palmerston-Stanley, Mansel, Jowett, and Green-Ireland in 1870-In the episcopal palace at Cloyne- The Querist'-Maynooth and Doctor Russell-Butler's 'Analogy' or Locke's 'Essay'? - The Clarendon Press-Butler at Stanbope in 1726-38Locke's early life in Somerset-Nynehead Cour't-Locke and Esther Masham's corlespondence-Locke's library at Horseley Towers - Tennyson at Farringford - The Queen's Jubilee in 1887-Summers at Rydal and Grasmere-Fox How-Summers in the vale of Yarrow-Two benerolent pastors-Doctor' Russell's 'Reminiscences'Scott and Wordsworth in Yarrow-Life in YarrowJolnn Veitch . 


\title{
CHAPTER VIII.
}

\author{
IN TENEBRIS LUX.
}

1591-1904.

In retirement-Hawthornden - 'Locke' in 1890-An annotated Locke's 'Essay' in 1891-94-Locke's criticism of "experience"-Humes Question-The English Philosophical Succession - Kant's criticism of reason in experience - Kant the complement of Locke - Gifford Lectures in 1894-96-Theistic Philosophy - "Natural causes" - Science presupposes God - Spencer's undenominational Religion-Comte's three stages - Theism, Metaphysic, and "Positive Science" in their mutual relations - The constituents of Theistic Faith-Philosophical rationale of Theistic Faith - Development consistent with Theistic Faith-Order in Things and moral disorder in Persons-- Can this be reconciled with Theistic Faith?-How things depend on persons-Supreme significance of persons in the Universe - Natural Onder and personal free agency-Mysteries are not necessarily contradictories-Human interest in Theistic Faith-Must Persons be immortal? - Theistic Hope-Supposed signs of human immortality-Atheistic, Pantheistic, and Theistic Philosophy-Theistic Philosophy the ria Media-Objections to the Via Media-Theistic Philosophy and Christianity-Gospel of Theistic Faith and Hope and the Gospel of Christ respond to one another-A final QuestionVisit to Holland-'Life of 'Thomas Reid' in 1898-Isle of skye-Charles Edward and the '45-Berkeley reedited in 1899-1901-The Land of Lorne revisited . 


\section{BIOGRAPHIA PHILOSOPHICA.}

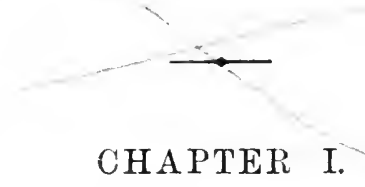

IN THE LAND OF LORNE: EARLY MEMORIES.

1819-1833.

"Those recollected hours that have the charm

Of visionary things, those lovely forms

And sweet sensations that throw back our life,

And almost make remotest infancy

A visible scene, on which the sun is shining."

-WORDSWORTH.

Perplexities of religious thought have been at all times springs of metaphysical reflection. It was by them in crude forms that I was first attracted to inquiries which have engaged my life. The originating Cause of the universe in which I found myself, and how I could know that this Cause was God, were questions that disturbed my boyhood seventy years ago. I had been wont as a child to picture God as a King upon a throne, in remote solitude in the blue sky, yet anon interfer- 
ing, in an arbitrary way and with awful severity, in the affairs of the planet which I had lately entered, and which I was told had been suddenly created by God six thousand years before. I wanted proof that this was so. A book of theological lectures by Dwight, President of Yale College, and son-in-law of Jonathan Edwards, was often consulted for help, in its opening discussions on natural theology. In searching my father's library for some book which might relieve my secret distress, on account of thoughts which seemed to involve deadly sin, I had lighted upon this book, and found that it touched my perplexities. It told me that God was needed to explain the world, because an eternal succession of finite causes was an absurdity; and also that Matter could not be the supreme cause, inasmuch as it must itself have been caused by an antecedent. This somehow aggravated instead of relieving my difficulties. For I failed to see the absurdity of an unbeginning and endless succession of changes; or at any rate why latent powers in Matter might not explain everything. And this arbitrary Governor of the world, living somewhere in the firmament, seemed as much to need a God to explain his own existence as any of 
the persons or things he was supposed to account for. About my thirteenth and fourteenth year all this occasioned anxious thought.

Questions about birth and death followed. If the conscious lives of men continue after their bodies die, why do those who believe this not add the years after death to those before death to determine their present age, and so speak of St Paul or of Cæsar as now almost two thousand years old? And then, in an endless life, how can I, a million times a million years after this, remember anything that happened in the present century, or have interest in, or identity with, the boy now living on this earth? Questions of this sort haunted me in indistinct forms, with restless craving for settlement.

I can hardly tell when or how these thoughts first rose. What am I? What sort of universe is this in which I find myself? What is to be its final upshot and mine? These questions were all working in me in a dim, half-conscious way. Perhaps this is common among the young. I do not find, in my early surroundings, or in family antecedents, how, so early and so long, they came to occupy my thoughts. But influence of place and race must not be overlooked. 
My father was a minister in the Chureh of Seotland. I first saw light in $1819,{ }^{1}$ in the manse of Ardchattan, on the shore of the north side of Loch Etive, in the romantic Land of Lorne in Argyllshire. Lorne is bordered on one side by the Western Sea, and the Grampians guard it on the east-a region mostly of green undulating hills of moderate height. Its northern part consists of two peninsulas-one the country of Appin and of Jacobite and Nonjuror Stewarts, opening to the east through the awful defile of Glencoe; the other the peninsula of Benderloch, possessed by Argyll, Breadalbane, and Cawdor Campbells, separated from Appin by Loch Creran, and from south Lorne by Loch Etive. Oban was the local metropolis, eighty years ago a modest seaside village, now a summer resort of fashion. Cruachan is the mountain monareh of this historic region.

The manse of Ardehattan in Benderloch, isolated from the world on three sides by the sea, and on the east by pathless mountains, was an ideal home for meditative seclusion. It was circled by hills, varied by valleys and elear streams, with luxuriant vegetation like Westmoreland or Wales.

1 On September 3. 
Early impressions of this sublime panorama, unfolded around the manse, are now more vivid in my imagination than any later experience in this world of sense. Benderloch was full of mythical traditions and historic memories. Pictish myths of regal state at Beregonium, the fabled capital of the Picts, and Ossianic dreams of Uisnach and his sons; in more credible history, encounters of Bruce with the Lords of Lorne; later still, tragic incidents in the wars of Montrose; also relics of mediæval faith in the ruined priory of Ardchattan, or of feudal life in the castle of Barcaldine. In its insular isolation Benderloch was seldom visited by travellers, although in September 1803 Wordsworth and his sister passed through it in their Scottish tour; and in 1824 MacCulloch described in glowing language the route from Connel to Loch Creran. "Everything," he says, "is beautiful on the road between the two lochs. It is but five miles, but it is a day's journey to a wise man; and the castle of Barcaldine, with its freshness and its avenue of living trees, carries one back into the past with a startling vividness." ${ }^{1}$ To-day a railway from

1 The old castle is now (1904) in process of restoration by Sir Duncan Campbell of Barcaldine. 
Connel to Glencoe traverses the two peninsulas of Benderloch and Appin, opening to the world some of the grandest scenery in Britain.

My family inheritance was Celtic. My father traced his descent from a branch of the Frasers of Strichen, who in the seventeenth century possessed a small property at Tyrie in Aberdeenshire. Ardent support of the House of Stuart was their ruin. Soon after 1715 , shattered in fortune, they migrated to Stratherrick on Loch Ness, to the lands of their kinsman, Fraser of Foyers; and some years before Culloden they had moved to Croy in Strathnairn, where my great-grandfather and grandfather held land on Kilravock. Culloden is in the parish of Croy, and my great-grandfather, lame at the time through an accident, told how he watched the scene, before the battle began, in a shower of sleet which soaked the ground; how the battle when it came lasted only for a short half hour; then how he saw the tide turn, the Highland army in retreat to Inverness or to the mountains, and the Prince with a few companions in tlight over the moorlands to Stratherrick.

My grandfather, unlike his Jacobite and Nonjuror ancestors, was an evangelical presljyterian, 
although his grandmother was a daughter of John Gordon, the last bishop of Galloway before the Revolution, who was afterwards a convert to Rome, and is still remembered as the subject of the Decision of Pope Clement XI. in 1704, which disallowed Anglican ordination for the Roman communion. The fervid Calvinism of Calder, the good minister of Croy, converted my grandfather to Presbyterianism; and so it was in the Puritan atmosphere which sheds awful solemnity over human life that my father passed his youth in the last two decades of the eighteenth century.

My mother was a daughter of Alexander Campbell, laird of Barcaldine and Glenure, who was descended from the knights of Kilchurn, and was head of one of the families that divided among them the peninsula of Benderloch. Her granduncle, Colin Campbell of Glenure, a younger son of Barcaldine, and of Lucia, daughter of Sir Ewan Cameron of Lochiel, was the victim in the celebrated Appin murder by gunshot in the wood of Lettermore, in May 1752, which inspired Gleig in his novel of 'Allan Breck,' Stevenson in 'Kidnapped,' and Neil Munro in 'Doom Castle.' The mystery of this murder touched my imagination in those early years. The murdered 
Campbell was in 1752 factor of estates in Appin forfeited by the Stewarts after Culloden, and was obnoxious as the agent in evictions. James Stewart at Acharn, in Appin, was condemned as a conspirator, and was hung in chains at Ballachulish; Allan Breck, the reputed actor, escaped to France. In my childhood I knew an aged native who remembered the ghastly spectacle of the skeleton under the moon, on winter nights the terror of her youth. The 'Scots Magazine' tells that it was blown down in a hurricane three years after the execution, and by order of the court in Edinburgh was again suspended. The end of Allan Breck is told by Scott in the Introduction to 'Rob Roy'; but unless Mr Andrew Lang has the key to the mystery, the murder of Glenure is likely to retain a secret for ever.

A more remote maternal relative than Glenure was Colin Campbell, laird of Achnaba, a son of the first laird of Barcaldine, and minister of Ardchattan from 1667 till 1726; in repute among contemporary mathematicians, intimate with the Gregories, and a correspondent in Latin of Sir Isaac Newton. He was a metaphysician too. He produced for his own satisfaction a 'Demonstration of the Existence of God,' before Samuel 
Clarke's 'Demonstration' was given to the world; likewise an 'Essay on the Divine Trinity in Unity.' Both were privately printed a century and a half after his death. They suggest knowledge of Descartes and Spinoza and Locke's 'Essay.' What one of Campbell's correspondents calls his "vicious modesty" has concealed him from fame. I well remember his granddaughter in the summer of 1826, a few months before her death, in the beautiful home of her old age, at Gallanach near Oban. She was then in her hundredth year;--born when George I. was king and Walpole Prime Minister, when Newton and Clarke were still alive, before Berkeley had seen Rhode Island, when Locke and Leibniz were lately dead, and when the romance of the ' 45 was far in the future. A brother of my venerable friend was killed at Culloden.

Campbell's 'Demonstration' is not uninteresting in metaphysical theology. It turns in one part on our conception of Power and in another on our conception of Infinity. That everything which had a beginning must have had a producer, or "that there must be something before everything that began," is one of his postulates. That whatever is limited must at last be limited by a 
Being that is unlimited, is another. And the infinite Being must be uncompounded, for otherwise each part of the compound would limit the other parts and the whole. Finally, whatever is uneompounded must be Spirit. But a human conception of infinity must, he confesses, be inadequate. "The indivisible Infinite or Perfect, who out of nothing made all except Himself, hath not possibly in His own nature this and that, nor now and then in His duration; albeit our weak faculties attribute to Him different faculties and times: these are all in His infinity an indivisible point, whose cireumference is nowhere, and whose centre is everywhere. Therefore we cannot know God in His infinity, albeit we know what finitude can know of Him. Our finite knowledge of God may be true, but cannot be perfect with respect to its infinite object, while both true and perfect with respect to the finite subject; and this not for defect of Gorl's power to reveal, but from defeet in the nature of the subject to whom the revelation is made. I eertainly see that God is, and yet I see that He is infinitely more than I can see. If we intend more in rising to these sublime thoughts than the raising of our derotion to the object of our thoughts, and presume curiously to pry into the 
Divine Majesty, we shall be confounded with the glory, as the eye is blinded by looking on the sun." In the tract on triune Deity Campbell argues that God must be triune from the impossibility of His having existed in solitude prior to the creation of the universe. "Therefore God did eternally beget God; and this eternal Issue could not but reciprocally love and be loved; while this mutual Love, proceeding from the producer and the produced, we may be allowed to call the Eternal Spirit." Hence the need in reason for triune Deity. All this touches the imagination, when we recollect the troubled time and the rude surrounding society. ${ }^{1}$

My mother was the chief early influence in my life. I was devoted to her in childhood with a romantic affection. In my first seven years she was my only teacher. She had been educated in England, and afterwards lived much in the South; for years at Clapham, where she formed lifelong

1 Campbell's courage was shown when he volunteered to declare the parish of Ardnamurchan vacant, after the deposition of the popular "Mhaighstir Alasdair," who refused to conform to presbytery. "Dressed in the kilt, and armed with a sword in one hand and a cocked pistol in the other," Campbell, we are told, "defied the stormy audience and delivered his message." See 'Among the Clanranalds' (p. 140), by the Rev. Charles Macdonald, priest of Moidart (Oban, 1889). 
friendships with Cecils, Elliotts, Venns, and Clarksons of the "Clapham sect" of evangelical churchpeople, commemorated by Sir James Stephen, representatives of the gracious religious philanthropy which transformed English society and the English Church in the early years of the nineteenth century. She inspired my childhood with her own Anglican enthusiasm. Dulwich and Norwood and Balham, Clapham Common, with its lawns and cedars as they were before Greater London had submerged them, also the Thames at Reading, all scemed, when I first saw them in later years, to be part of the familiar experience of childhood. My favourite nurse-maid, Anne M'Coll, who had been with my mother in England, and shared her affection for its life and Church, added her influence. It was encouraged by books given to me-Goldsmith's 'History,' 'Robinson Crusoe,' 'Sandford and Merton,' tales by Hannah More and by Legh Richmond, and the 'Fairchild Family,' with its curious pictures of evangelical life in the Church of England, and of scenery in Worcestershire and Berkshire. The sunny lands of the South were in this way invested with a lasting halo in the fancy of a dreamy child in the Land of Lorne. When the "Tales of a Grand- 
father' appeared in 1827, the Scotland of Scott was a rival inspiration, at a time when faint echoes of Culloden were still reverberating among the Highland mountains.

I was the eldest in a family of twelve. We lived a self-contained home-life of Spartan frugality. The modest income of a parish minister in the Church of Scotland was reduced by my father's generosity to a brother. In consequence the ten sons had a strong motive for testing the law which confers survival in the battle of life. Like the vicar's family described by Goldsmith, "we loved each other tenderly, and our fondness increased as we grew older. We had no revolutions to fear, nor fatigues to undergo; all our adventures were by the fireside, and all our migrations from the blue bed to the brown. And it is needless to attempt describing the characters of young people that had seen but very little of the world."

My own experience was confined within the isolated peninsula of Benderloch during my first fourteen years, except a few weeks in Strathnairn in 1824, and a few days in Glasgow in 1829. I grew up a shy, awkward boy; unobservant of what lay outside some strong individual tastes; 
physically educated by lonely walks, work in the manse garden or oaring in a boat; and with no outside youthful companionship.

My earliest recollections go back to 1822 . In August of that year an English clergyman and his wife visited the manse. I have now a distinct mental picture of their arrival, an uncommon event in that solitary region. They had come from seeing George the Fourth keep Court at Holyrood. Their report of the doings in the Scottish metropolis, prolonged in family talk, as of a great event, exercised my fancy, and Edinburgh was pictured as the New Jerusalem, and King George moving about with a golden crown upon his head. A visit of the Rev. Legh Richmond, author of the 'Dairyman's Daughter,' is a more dimly remembered incident, I think also in 1822.

A memory which belongs to the following year is due to talk at the time about the murder of Weare, a London gentleman, by Thurtell, son of an alderman in Norwich, under singular circumstances of treachery and atrocity, in Gill's Hill lane in Hertfordshire. The particulars so affected me that half a century afterwards I spent a summer day in and around that Hertfordshire 
lane, comparing the localities with the evidence taken in the trial. It was this Gill's Hill lane murder that suggested to Thomas Carlyle a definition of "respectability." At 'Thurtell's trial occurred the following colloquy: "What sort of person was Mr Weare? He was always a respectable person. What do you mean by respectable? He kept a gig." Carlyle long rejoiced in "gigmanity" as a synonym. Thurtell also figures in De Quincey's essay on "Murder considered as one of the Fine Arts."

The visit to Strathnairn in August 1824 is prominent among these relics of childhood. A steamboat was then a novelty in the Highlands. We travelled to and from Inverness in the "Comet," the earliest experiment in Highland steam navigation. The "Comet" was memorable for its tragic fate in the following year, when in a dark October night it was suddenly submerged in collision with another steamer, at the entrance to the Clyde, and more than sixty passengers were drowned. As many of them inhabited Argyll and Inverness, families around us were mourners, and faith in steam as a motive force was for a time suspended in the Highland mind. In Nairnshire we were entertained at the manse 
of Cawdor by Mr Grant, the old minister, who had helped to entertain Johnson and Boswell more than half a century before, when his manse was occupied by a Macaulay. Boswell tells how he had "dreaded a whole evening" at Cawdor manse for Johnson, as likely to be "heary," but that "Mr Grant, an intelligent, well-bred minister in the neighbourhood, was there, and assisted us by his conversation." Their host that evening was Lord Macaulay's unele; and when he died our host Grant sueceeded him. It happened too that early in that summer an aunt of Lord Macaulay visited my father's manse. I remember a picnic on our glebe and various encounters with Miss Macaulay, as well as the tradition of her pride in her young nephew "Tom," then at Cambridge, soon to become famous through his essay on Milton in the 'Edinburgh Review.' The Macaulays are connected by birth with Ardehattan, for the historian's grandmother was a daughter of Campbell of Inveresragan, whose small family property, in the eighteenth century, was within a mile of my birthplace; their home was among the yewtrees of Blarereen, and their tombs are in the chapel of the ruined priory at Ardchattan. 
The summer of 1826 was, I believe, the hottest and driest in the nineteenth century. Almost no rain fell from May till August. I recollect the long-continued sultry haze over the mountains of Lorne, Loch Etive daily a sea of glass, the smoke of kelp-burning ascending from its rocky shores, and the sunsets reflecting the hills of Mull and Morven in purple and crimson and gold. I can picture a sultry Sunday in that year in the quaint, rudely furnished, crowded parish church, then beside the manse, and the welcome given to the sublime imagery of the Apocalypse in the words which formed the text: "These are they which came out of great tribulation, and have washed their robes and made them white in the blood of the Lamb. They shall hunger no more, neither thirst any more; neither shall the sun light on them, nor any heat." That whole summer of 1826 is now the beautiful dream of childhood-

"Heaven lies about us in our infancy."

Dunollie is another memory. It was early in that sultry summer that I was first taken to visit this romantic home of the MacDougalls, once Lords of Lorne. Their ivy-clad castle, which guards the 
entrance to Oban Bay, is the most picturesque ruin among the Hebrides. We were entertained by the mother of the chief; her son was in England on the eve of his marriage. Scott describes a meeting with this distinguished Highland lady when he visited Dunollie, on his way home from the Orkneys in 1814. "She was then in deep mourning for her eldest son, who had fallen bravely in Spain under Wellington, a death well becoming a descendant of so famed a race. The second son was a lieutenant in the navy. Mrs MacDougall spoke with melancholy pride of her eldest son, and with hope of the survivor." That second son was now the laird, later on distinguished as Admiral Sir John MacDougall, for forty years lord of Dunollie, a familiar figure and friend in my early years, a gallant officer, erect, alert, with an air of command, proverbially hospitable, "tenacious of his dignity," not unlike the Lochbuie described by Samuel Johnson, who, when the celebrated Englishman was introduced to him in Mull, condescendingly asked him whether he was a Johnston of Glencoe or a Johnston of Ardnamurchan.

I have a faint remembrance of the parliamentary election in July 1826 . The contest in 
Argyllshire was between Campbell of Islay and General Duncan Campbell of Lochnell. The General was the chief magnate of Benderloch, the patron of the parish, a dignified gentleman, with the ceremonious courtesy of the old school, long a member of Parliament, and nearly related to the House of Argyll. In 1794 he raised the 91st Regiment, soon after served at its head in South Africa, and early in last century held a command in Ireland. The last thirty years of his life were spent at Lochnell, a centre of active benevolence in all those years. His wife was a sister of Sir George Murray, the friend of the Duke of Wellington, and Secretary for the Colonies in the Duke's Cabinet in 1828. An influx of distinguished visitors at Lochnell enlivened the summers at Ardchattan.

In 1827 I began Latin, and during most of that summer I went for an hour or two daily to the parish school. This was all the experience I have ever had of school-life. In autumn typhus fever put an end to it, and almost put an end to my life. In the five following years Latin was administered to me privately at the manse before breakfast, by Archibald M'Callum, our worthy schoolmaster, a man simple and pious, of the 
old-fashioned sort, narrow in his views of life, gratefully remembered for his goodwill. But Cæsar and Virgil, mechanically taught, awoke little human response, and my faculty for languages was not strong. Although Virgil and Lucretius and Tacitus have charmed me in later life, these five years of philological drudgery did little for head or heart. I lounged over Latin lessons, and at the end could construe in a slovenly way classic books through which I had travelled unsympathetically. This waste in the morning of life has been an irreparable loss.

The parish school at Ardehattan in the eighteenth century, like others in Scotland at that time, was resorted to by all ranks - the sons of the laird and the sons of the cottar. In the later years of the century it was taught by $\mathrm{Mr}$ Corrie, afterwards a parish priest in the Anglican Church, whose son Daniel, born in Benderloch, was seventy years ago the first Bishop of Madras, a friend of Henry Martyn and of Heber. One of his father's pupils at Ardchattan was Colquhoun Grant, a son of the minister of the parish, afterwards Sir Colquhoun Grant, and a distinguished figure at Waterloo. He succeeded 
Ernest, Duke of Cumberland, in the command of the 15th Hussars. Asked by his Royal Highness about the place of his nativity, Grant said that his father was "minister at Ardchattan." "Minister at Ardchattan? Ardchattan?-I never heard of that Court," was the Duke's rejoinder. The numerous sons of the laird were among Colquhoun Grant's schoolfellows.

During those five years of Latin under the old schoolmaster I was educated chiefly by influences outside Latin. Eye, imagination, and reason were much in my own keeping; teaching was incoherent and desultory. The 'Edinburgh Evening Courant' was an educating factor. It came to the manse on three days of each week, when it was three days old. I used to meet the runner to anticipate its delivery-the first to get longed-for news about the far-off world beyond the mountains. The struggle of Greece with Turkey in 1827 was, I think, what awoke me to contemporary history, and the battle of Navarino in October was an absorbing interest. In home politics I remember the announcement one morning of the resignation of Lord Liverpool, and interest felt afterwards in the brief rule of Canning, then of Lord Goderich, and in the following winter 
in the formation of the Wellington Cabinet. The war of Russia with Turkey in 1828-29 was an endless excitement, and I could long after recount the successive movements of the armies, with the battles and sieges, in more exact detail than any recent history. The gloomy forebodings of the worthy ministers in Lorne, when the Catholic Relief Bill was passing in 1829, were somehow heard with mixed regard. On the journey to Glasgow with my parents in that year, I well remember our landing at the Broomielaw when the newsboys were announcing that the Bill had passed the House of Lords, and the dismay of a clerical party at the house of our host - their lurid prognostications of bloody persecution, as the lot of the new generation. In 1830 the death of George the Fourth, whom I had been wont to think of as part of the unchanging system of nature, was like the disappearance of the sun out of the heavens. But the cabinet-making of Earl Grey, and the great Reform Bill struggle under Lord John Russell, with predictions of a terrible Revolution, awoke new interests, and I found myself suddenly in a new world. The debates from March 1831 till June 1832, the successive 
general elections, the Bristol riots, withal the invasion of eholera, give a tragic aspect to a vivid retrospeet of the early 'Thirties. Yet the political development was watehed, not in a partisan spirit, but as an absorbing dramatic spectacle; for I do not remember having sided either with Sir Robert or with Lord John.

My mother trained me in the Bible. Old Testament history filled my imagination. Genesis was a coustant delight; and when a child I eould not listen without tears to the story of the death of Absalom, or of David and Jonathan. The eharm of the Gospel biographies and the grand pictures in the Apocalypse softened the rigid ritualism of the Highland Sabbath. Job and Ecclesiastes were attractions of a later day.

Books of history of all sorts were favourites, -Rollin for the aneient world, Walter Scott for Scotland, Hume for England, and Robertson for America. I remember a long summer day in 1830 spent at a public sale of the library of Captain Campbell at Kilmaronaig - one of the numerous captains and majors, as well as soldiers from the ranks, who abounded in Lorne in the generation after the French war. I exhausted my pocket-money in buying three books of 
history - Hume's 'England,' Ferguson's 'Roman Republic,' and the 'General History' by Lord Woodhouselee, all proudly carried home. It was my introduction to the name of David Hume, since more familiar as the sceptical metaphysician than as the old-fashioned Tory historian. Adam Ferguson, too, I have since learned to associate more with philosophy in Edinburgh than with Roman history. And Woodhouselee is a place associated with some of the happiest social experience of later life.

Books of travel were a frequent indulgenee, - the adventures of Parry and Franklin in the Polar regions, pictures of South America by Humboldt, and of India by Bishop Heber, the many volumes of the 'Modern 'Traveller' and of Constable's 'Miscellany.' The 'Arabian Nights' and 'Gulliver' were less easily accessible. Ordinary novels were under interdict, those of "Waverley" being pre-eminent for bad report. My worthy schoolmaster repeatedly warned me against Sir Walter, with an ominous foreboding of his final destiny, on account of the "books of lies which the devil had tempted him to produce." The liberal education implied in intercourse with Scott was thus out of my 
reach, although I got Scottish history from his 'Tales of a Grandfather' in and after 1828.

Popular astronomy above all was enchanted ground. I was strangely moved by the idea of the human family as fellow-passengers on a huge material ball, navigating boundless space, subject to the incalculable possibilities of the crowded hearens, and my own loneliness emerging as a stranger on this revolving globe. Exercise of fancy upon astronomical manuals for children helped, I daresay, to raise those questions about the Power at the heart of the universe, and our destiny in it, which disturbed my boyhood, and relaxed the faith of childhood in a way that the novels of Scott or Bulwer could never liave done.

My aunt, Caroline Campbell of Barcaldine, was, with the starry heavens, an expansive influence in those years. She was less emotional and more argumentative than most women; given to theological argument, a defender of Arminian and Pelagian theories, and fond of criticising Calvinistic orthodoxy at the manse. It was in her hands that I first saw Locke's 'Essay,' too soon to appreciate it, studied afterwards with a sympathetic sense of its healthy realism. My aunt 
was a visitor at the house of Robert Owen, the celebrated socialist of New Lanark, Owen's wife being our cousin. Partly for the pleasure of the argument, she used to plead for the dreams of this benevolent enthusiast, disturbing my childish ideas of the human world, as the books of astronomy disturbed ideas of the material universe. Also her reports of the family of her cousin, Sir Guy Campbell, who married a daughter of Lord Edward Fitzgerald, the famous Irish patriot, added interest to the reports of contemporary Irish agitation, led in the early "Thirties by Daniel O'Connell, and in the affairs of Ireland, to-day administered by the great-grandson of Lord Edward Fitzgerald.

Local history and its educating influence must not be overlooked in a retrospect of those faroff days. On the shore of Loch Etive, a quarter of a mile from the manse, are the picturesrjue ruins of the Priory of Ardchattan. The prior's house was the modern mansion of the laird. The Priory, the charming well-timbered parks which surround it, and the well and chapel of St Modan on the hill, were my favourite haunts. They awakened dreams of bygone centuries, when 
monks, devout and learned, were charitably supposed to occupy this holy ground, with "savage clans and roving barbarians" in all the surrounding country. In 1216 Malvoisin, Bishop of St Andrews, carried into Scotland the Order of Benedictine monks of Vallis Caulium in Burgundy, and establishments of that order were founded at Pluscardine, at Beauly, and at Ardchattan. The early records of Ardchattan Priory were destroyed in the wars of Montrose, and little is known of its history before Alexander Campbell, of the House of Cawdor, the last prior. It was dissolved in 1602, and by royal charter this Alexander Campbell became laird of Ardchattan. His successor in the first forty years of the nineteenth century was Robert Campbell-_. Ardchattan," or "the prior" as he was affectionately called-whose humour and kindness diffused happiness around. He had served in the army of the East India Company in Bengal before Warren Hastings returned to England, and when Sir Philip Francis led the opposition; and his tales of Indian adventure opened a new world to us all. A large family of brothers served their country like himself. One was killed in the battle of Camden in the American war, and another at 
the siege of Pondicherry. Two others fought in different parts of the world, and a third was lord of the manor of Gatcombe, in the Isle of Wight. The youngest of all, Laurence Dundas Campbell, after a short military service, turned to literature. He was editor of the 'Asiatic Register' in the first years of the century, and published books on Indian policy; but my attraction to him was for his 'Life of Hugh Boyd,' intended to vindicate a claim for this wayward Irishman to the authorship of Junius. Accordingly the mystery of Junius later on became one of my hobbies, like the Appin murder; but I reached only the negative conclusion, that it had not been solved by Campbell. He died in middle life in 1809. His wife was a daughter of John Courtenay, member for Appleby, a distinguished parliamentary follower and friend of Fox. The last years of her widowhood were spent at the Priory, and this accomplished lady is another attractive figure in the recollections of my childhood.

Inverawe is a paradise of sylvan beauty on the south side of Loch Etive, on the bank of the river Awe. With its legends it has associations with those years. Then a home of the Campbells 
of Monzie, it was possessed by General Alexander Campbell, and in succession by his son, the chivalrous and accomplished member for Argyll, a leader of the Free Church movement in the 'Thirties and 'Forties. In the eighteenth century Inverawe was held by another Campbell family, of which the last male representative was killed at the siege of Ticonderoga in 1758. The legend of the vision which years before warned Inverawe of his fate, took the fancy of Dean Stanley, and was given by him in 'Fraser's Magazine,' and by Lord Archibald Campbell in his 'Records of Argyll.' Inverawe, it seems, had unwittingly rescued the murderer of his foster-brother, who came to him for protection, hiding him in a cave on Ben Cruachan. The ghost of the murdered man appeared once and again to Inverawe, demanding the murderer, but in vain, for the laird's honour was pledged; the vision finally disappeared, bidding him "beware of Ticonderoga," a fortress in America, then unknown by name in Scotland. Years afterwards Inverawe was ordered to join his regiment in the Franco-American war. There he was engaged in storming a fort, which he was told was Fort St Louis. He was wounded fatally, and before 
he died he diseovered that the name of the fort was Ticonderoga. But my cousin, the late Mrs Campbell of Monzie, is my happiest association with Inverawe.

Bonawe, on the opposite side of the river Awe, was the headquarters of a company which for a century after 1753 imported iron-ore from Ulverston to be transformed into pig-iron at Bonawe, in a furnace supplied with timber from the surrounding forests of Muckairn, redolent of bireh-wood and bog-myrtle. Wordsworth was a visitor at Bonawe House, I think in 1833. It was then that I first heard his name, but without the associations which have since gathered round it. This was his second visit to Bonawe; the first was in 1803.

Life in the manse on the isolated peninsula in Lorne was now and then varied by visits of neighbouring ministers. The Church of Scotland there, as elsewhere, presented, on one side, the religious fervour, sacerdotal temper, and dogmatic severity, and, on the othcr, the tolerant and humane, albeit less other-worldly and more accommodating spirit, which distinguish its two schools -one dominant in the seventeenth, the other in the eighteenth century-contristed as Evangelical 
or High, and Moderate or Broad Church. The one was the complement of the other; each predominating, as religion was regarded chiefly in its divine or chiefly in its human relations. Controversies between the ministerial representatives of each enlivened presbyterial life in Lorne. Ministers of both parties are associated in my retrospect with kindness and goodness in that quaint old-world life.

Alexander Stewart, afterwards minister of Cromarty, is prominent among the ecclesiastical personalities of my childhood. He was then a licentiate of the Church, who had come to Benderloch from the Lowlands to learn Gaelic. The droll unconventionalism of this recluse student, who used to share my childish gambols on winter evenings in the manse, are still vivid in my memory after the lapse of eighty years. I have not met him since. According to Hugh Miller, who was one of his parishioners at Cromarty, Stewart was "one of the most original thinkers and profound theologians," and, "with the exception of Chalmers, the sublimest of Scottish preachers." He died in middle life, too modest for authorship, and indifferent to fame. A posthumous volume of sermons hardly justifies the affectionate eulogy of Miller; and the 
quaint analogies in which they abound have little affinity with modern religious thought.-A picturesque figure in the ecclesiastical life of Lorne was Patrick MacDonald, for almost seventy years minister of Kilmore. He died in 1824 in his ninety-sixth year. His genius lay in music, in which he was an original composer, and he edited a rare collection of "Highland Vocal Airs," of which I think there is a copy in the Bodleian Library at Oxford. More tolerant of religious differences than was common, a "Nathanael in whom there was no guile," this good man married an excellent lady of the Roman communion, who in all their married life never joined in prayer in church or in the family with her husband. He occupied his manse at Kilmore when Johnson and Boswell travelled through the parish on their journey from their "tolerable inn" at Oban over Midmuir to Inveraray, on a tempestuous Saturday in October 1773: the young man who had been their guide was an old man living near us in my youth.-A contemporary of MacDonald was Joseph M'Intyre, for almost sixty years minister of Glenorchy, a friend of Scott, and also of "Christopher North," who was a summer visitor in Lorne in the 'Twenties; also of Zachary Mac- 
aulay, who with his son "Tom" spent part of 1813 at Soroba near Oban. In a letter to Hannah More, he records a pleasing incident of the venerable pastor of Glenorchy and Mansel, Bishop of Bristol.-Another notable among the presbyters was John Stewart, minister of Lismore in the first three decades of the nineteenth century, thus described by one who knew him well : "A curiosity in his way; of the shortest stature; rubicund; his capacious vest bepowdered and embrowned with snuff; his silver snuff-box in one hand, in the other the ready pinch; the shortest arms; nether limbs in proportion, sunk in top-boots which covered almost all of them that was visible; a generous nature; hospitable to a proverb; a lover of peace and laissez faire; yet withal a party man who never failed to answer the ecclesiastical war-cry of his 'Moderate' friends when it arose." Stewart was the successor at Lismore of Donald M'Nicol, a Celtic poet, remembered as the caustic critic, whose 'Remarks,' published in 1779, on Johnson's 'Journey to the Hebrides' helped to relieve the temper of sensitive Gaels who were offended by the free speech of the English traveller.

The Land of Lorne became about that time un- 
wittingly an agent in the expansion of religious thought in Scotland. John MacLeod Campbell, the friend of Thomas Erskine, Alexander Scott, and Frederick Denison Maurice, was a son of the minister of Kilninver. This good man, minister of Row, excommunicated in 1831 as a heretic by both parties in the Church, is now recognised as a forerunner of the larger charity by which the churches of Scotland have been characterised in later years. I remember his sermon on the love of God in the old parish church of Ardchattan, more than seventy years ago.

My faculty of observation was too little exercised in those years upon things and persons. Experience came to me chiefly through books. Natural reserve among strangers was increased by what Celts consider culpable ignorance of Gaelic, the key to the life of the Lorne peasantry. Gaelic is interesting to the philological specialist, and the language is full of the poetry and romantic story of the Scottish Highlands. But with no exceptional linguistic faculty, and no urgent need for exercising it in that way, I grew up almost as ignorant of Gaelic as of Chinese. In later years available strength has necessarily been given to literatures more connected with 
favourite studies. The mystical enthusiasm of the Celt is apt to react against the cold severity of Baconian induction of experience and logical conditions of proof; and intense tribal patriotism is averse to cosmopolitan views of life. Gaelic literature contains little that is directly auxiliary to science, or in affinity with philosophical speculation, unless through the fondness of the Celt for problems of Calvinistic theology and for ecclesiastical differences. The sermons of Jonathan Edwards, Boston's 'Fourfold State,' and books of English Puritans, especially those of Bunyan, were in those days favourites in my native peninsula. 'A Vision of Heaven and Hell,' appended to an old edition of the 'Pilgrim's Progress,' was in demand. The pictures terrified my childish fancy. I have not seen it since. It was there that I first encountered the name of Hobbes, who was found by the seer, in his imaginary journey through the place of torment, expiating his guilt for having written the 'Leviathan.'

It is curious now to recall that dreamy life in the isolated peninsula of Lorne, with its oldworld society, in the days when George IV. 
was king; its Campbell lairds of Lochnell, Ardchattan, and Barealdine; at home with their families for nine months in the year, travelling in winter to Edinburgh to share for three months the social gaieties of the Metropolis-a three days' journey or more in the family coach-all of them long ago travellers in the sable car that carries us all to Hades; uniting Highland pride with much Highland hospitality; still in sympathy with their clansmen, the simple peasants, in whom the grace and chivalry of the Gael then survived, unspoiled by the Saxon stranger, all of them accepting the claims of rank with childlike deference. The circulation of news and the means of locomotion were slow; the packman of Wordsworth's "Excursion" did duty for the loeal newspaper which now enlightens Lorne; an oceasional 'Courant' or' London 'Morning Herald,' with tidings of the world beyond the mountains, passed from the house of the laird to neighbouring houses; visits of the postboy on two and latterly on three days each week were not seldom interrupted by storms; at least a shilling paid by the recipient for a letter from London, and tenpence for one from Edinburgh; the 'Courant,' in size a minialture of one of our halfpenny dailies, cost seven- 
pence; and the window-tax was an impediment to the light and air of heaven in our houses. In summer and in winter the rudely furnished bi-weekly or weekly steamer from Oban was the only public communication with the civilisation of the Lowlands. At home the picturesque garb of the Gael, on the very old and on the young, was a familiar sight; while the coloured coat and embroidered vest, instead of gloomy black, brightened the five-o'clock dinner-parties of the lairds, advancing afterwards to six, according to the fashion of the South. On Sundays the lairds and the peasantry for many miles round gathered, with their families, in the parish church, then happily one visible centre of the whole parochial community; supplemented at summer "Sacraments" by hundreds from other parishes, to be addressed in Gaelic by fervid preachers, in church and in the open air, till the day was far spent. Those who then shared in that remote life are now withdrawn from this world of sense; the social revolution in the reign of Victoria has dissolved the old society; and the wave of democratic equalisation, coming at first from France, has touched the shores of Lorne.

\section{3}




\section{CHAPTER II.}

\section{IN EDINBURGH : THE ENIGMA OF THE UNIVERSE.}

$1833-1842$.

"When I survey the dumb Universe, and find myself as it were lost in this corner, not knowing what has placed me here, what I have come to do, and what will become of me in the end, I feel like one carried in his sleep' into a desert island, who should awake wholly ignorant of his whereabouts," and with no means of escape. Assured that there must be more in the universe of reality than is revealed to sense, I set myself to try to find whether that Something is anyhow revealed to me."-PASCAL.

IN November 1833 I left my isolated peninsula in Lorne to spend the winter at Glasgow College. It was in those days the custom in Scotland to enter the university thus early in life; happily the fashion is different now.

During the preceding summer, in preparation for this change, instead of the good schoolmaster, I was placed along with my brothers under a resident tutor, Mr John Mackail, a man lovable in no ordinary degree, pious and studious, always remembered by me with gratitude: his son, the accomplished biographer of Morris, is widely 
known in the English world of letters. My brothers afterwards followed paths which led some of them to distinction in military or medical service in the army abroad, others to colonial life in Australia; while I followed the strong bent of nature in the home country, with little change of scene or picturesque adventure.

Through my tutor the classics of Rome came to me inspired with human interest, especially when the accustomed monotony of Livy was exchanged for the pregnant sentences of Tacitus. He also encouraged me to read some of Dugald Stewart's philosophy, and spoke about Reid and Berkeley with such effect that Horace and Tacitus declined into a second place; so in the end Stewart was withdrawn as a dangerous companion. But Berkeley had taken hold enough to raise doubt about my childish thought, that matter might explain everything, instead of needing itself to be explained.

The publicity and social collision of a Glasgow classroom came as a shock to a shy, sensitive boy, emerging for the first time from the lonely manse in Lorne. This, along with inadequate Latin and Greek, habits of desultory reading, and indif- 
ferent health in the surroundings of Glasgow, depressed me, and I felt myself a foreigner among my new associates. In May I returned to Loch Etive with the ideal formed in the previous summer clouded. Of my fellow-students I distinctly remember one, Alan Ker, born in Greenock, who indulged me with a speaking acquaintance. He was the most brilliant scholar in the Latin class; in after-years the brother-in-law of Tennyson, and in high office in Jamaica, where he died more than thirty years ago. Another, unknown by me at the time, now an honoured friend, was James Hutchison Stirling, whose 'Secret of Hegel' is a landmark in the history of philosophic thought in Scotland in the second half of the nineteenth century. Educated as I had been in solitude, I was disposed to silence and self-consciousness, and averse from varied intercourse or collision with mankind.

Notwithstanding, I now fondly cherish the memory of college life, on the old High Street of Glasgow, in that far-off winter-in quaint dingy courts, on dark winter mornings, as we gathered soon after seven to the sound of the college bell. Those old courts with their historic charm have 
since been exchanged for the modern splendour of Gilmorehill. I found William Ramsay newly placed in the Latin Chair, which he occupied with distinction for more than thirty years. I see him in his opening career, full of ardour, a gracious and accomplished young graduate from Cambridge. And I still seem to hear the songs of Anacreon, and the martial music of Homer, inspired by the tones of Sir Daniel Sandford, the eloquent Professor of Greek. It was Sandford's last winter of purely academic life. Political ambition carried this distinguished scholar, in March 1834, into the House of Commons as member for Paisley. After an ineffectual attempt to unite parliamentary with college work, the brilliant professor returned to Scotland, where he died in the prime of life. His father was Bishop Sandford of Edinburgh, who was described by Coleridge as " a thorough gentleman, upon the model of St Paul, whose manners were the finest of any man's upon record." But perhaps the professor I looked at with most interest was James Mylne, the successor of Reid in the chair of Moral Philosophy, a venerable personage, with an air of philosophic abstraction. I used to watch him on winter mornings, on his way from his house in the Professors' Court to the lecture-room. 
In 1833 Mylne was probably the most independent thinker in the Scottish philosophical professoriate, although he makes no appearance in histories of philosophy, or even in the philosophical library. He was, I believe, inclined to the school represented by Hartley in England and Condillae in France, rather than to the spiritual realism of Reid. A book of lectures by Professor Young of Belfast, who was one of his pupils, is said to be a recast of the prelections of the Glasgow professor. In polities Mylne was a philosophical Radical, and he offended many by going to a Glasgow public dinner in honour of Daniel O'Connell, when the Irish liberator visited Scotland. Besides watching the movements of Mylne, I sometimes in my solitude contemplated the children of the professors at play. I believe that one of those I used to see is now Lord Kelvin, whose father then filled the chair of Mathematics in Glasgow. In that spring, too, I saw at Paisley Sandford's election under the newly extended franchise of the great Reform Bill; and on another day I travelled in a steam-earriage on the lighroal between Glasgow and Airdrie, this locomotive agency being then and there experimented on, before steam on railways was known in Scotland. 
In November 1834, after a rather aimless summer in Argyllshire, I was transferred to the University of Edinburgh, and first saw the city which was to be the lome of my public life. From Loch Etive to Edinburgh was a three days' journey, in an open cart over rain-swept roads under a sullen October sky to Inveraray; then another night at Glasgow, after a voyage down Loch Goil ; and from Glasgow in a crowded canalboat drawn by horses. In that and the nine following winters I lived in Edinburgh: the intermediate summers were passed in study or relaxation on the island peninsula in Lorne.

The influence of Edinburgh upon a student is surely not confined to its university. Modern, like ancient, Athens is in itself a liberal education, with its extraordinary natural charm, its historic significance, and its literary tradition. For almost a century before 1834 it had been associated with men whose names live in history; raising this remote northern city to an eminence not unlike that of Paris in the time of Voltaire, or Weimar when it was the abode of Goethe. David Hume's 'Treatise of Human Nature' and Adam Smith's 'Wealth of Nations' are among the ever memorable books of the 
modern world. One of them was the spring of the greatest philosophical and theological revolution since Bacon and Luther, and the other is the chief authority in this era of industrial civilisation. Hume and Smith were both citizens of Edinburgh, and both were charming personalities; Hume is now buried on the Calton Hill, and Smith in the Canongate churchyard. Walter Scott had invested Scotland with a halo of medieval and Jacobite romance, and personified Edinburgh to the world. Jeffrey in the 'Edinburgh Review,' and Wilson in 'Blackwood,' had made periodical criticism an important agent in literature and politics. In 1834 the lights were fading. Scott had disappeared two years before, and others still alive were withdrawn by the increasing attraction of London. But Chalmers, the most eloquent of Scottish preachers, was at the head of a revived ecclesiastical life, through which Edinburgh was to become the centre of Church and State conflicts and disruptions, of which the final issues are still remote. The city itself was a bankrupt city, when I first saw it, on a misty afternoon in the end of October. Its population is now multiplied threefold, and in material 
wealth, if not in wealth of reason and imagination, it has increased in a still greater degree.

But the romance of Edinburgh was not at all in my mind when I entered the Latin class-room of its university. James Pillans, the Latin professor, was a graceful writer, the friend of Jeffrey, and an Edinburgh Reviewer who had not been overlooked in the satire of Byron. Pillans made Roman classics an agreeable text for introducing the uncultured youth of Scotland to the classics of English literature, otherwise neglected by the university, and through his humanising inspiration I found new attractions in the literature of Rome. His occasional lectures on the philosophy of grammar encouraged a metaphysical interest that was depressed in the experience of the preceding year. The genial kindness of Pillans, then and always, I recollect with gratitude, and it was a true pleasure, nearly a quarter of a century later, to be welcomed by him as one of his colleagues in the academic Senate. Dunbar, the Professor of Greek, was an industrious pedagogne, who repelled me from Greek literature, so that its inspiration was unfelt, until in later years Eschylus and Plato touched a chord.

I entered the logic class in the following winter. 
It was taught by Doctor David Ritchie, one of the ministers of Edinburgh, and was treated more as an appendage to his ministerial charge than as the professor's supreme interest, after a fashion not uncommon in philosophical professorships in Scotland about that time. The winter of 1835 was Ritchie's last, in a professorial reign of twenty-eight years, during which he had delivered to undergraduates in a diluted form the psychology of Thomas Reid and the logic of Watts and Duncan. Tall and gaunt, a powerful athlete in middle life, he was now the ghost of his former self. I seem to see the pale anxious face of the feeble old man as he made his daily entrance into the riotous classroom. Two volumes of sermons on Romans was, I think, his only contribution to the world's stock of books.

In 1836 philosophy was at a lower ebb in Scotland than at any time since the advent of Francis Hutcheson from Ireland to Glasgow, rather more than a century before, when the country was becoming diverted from ecclesiastical warfare, and turning to literary pursuits. In the seventeenth century Drummond of Hawthornden was almost the solitary representative of its literature, and Leighton of its religious philosophy. In 1836 
Thomas Brown had passed away sixteen years before, Dugald Stewart eight years, and Sir James Mackintosh nearly four. The Scottish chairs of philosophy were no longer occupied by philosophers. Sir William Hamilton was the anonymous author of two essays-afterwards famous, then known only to a few experts-one on man's ignorance of Infinity and the other on man's perception of Matter. It was the year in which James Mill died, and before his son with larger humanity had risen above the horizon. England was mourning the death of Coleridge, who had left no philosophical successor. It was different abroad. Cousin had awakened enthusiasm for metaphysics by his brilliant lectures at the Sorbonne, and was the chief living representative of philosophy in France; and Schelling was sustaining the great tradition of Germany in his chair at Munich. Hegel was lately dead; Schopenhauer in Germany and Comte in France had not yet come into view. Cousin, Schelling, and Hegel were all unknown in the Scottish universities.

I now returned to metaphysics and its ultimate questions. Thomas Brown, not Ritchie, was 
at first my chief teacher. In the previous summer by accident $\mathrm{I}$ found his leetures on mental philosophy in the manse library; they led me to his ingenious book on the relation of Cause and Effect. Brown recalled at a new point of view the enigma of the universe that was so distressing years before. The Power at work in the strange world in which I found myself was what I wanted to be assured about. What I ought to mean by the words "Cause" and "Power" was what I was now led by Brown to consider. It was a preliminary to the other question; and for a year or two after I left the logic class my thought was centred on this more abstract inquiry. I was for a time fascinated by the simplicity of Brown's superficial explanation. I had been wont to suppose that a "cause" meant a mysterious something, also called "power," somehow contained within things, but distinct from the visible things in which it was believed to reside. Abstract power itself was of course incapable of being presented to any of our senses.

Brown's analysis dissolved this coneeption as an illusion. The "powers" of things, he argued, must be the very things themselves which we see and feel; these, howerer, only when looked at 
as the invariable antecedents of changes which, under given conditions, make their appearance, and which we call "effects" of the antecedents. Causation, in short, is a relation of constant sequence, under which one group of phenomena is transformed into another group. All sequence, he of course insisted, is not causal sequence. Many sequences are only coincidences, and occur, as we say, by chance; the supreme purpose of scientific inquiry is to detect those sequences in nature that are really invariable, and to note the marks which separate them from those that are only casual. On its surface nature looks like a chapter of accidents; deeper insight discloses an inherent steady order or cosmos into which the chaos may be resolved. And progress of science consists in gradual resolution of accidentally connected events into their inherent orderly or causal articulation. This deeper conception of the universe is conception of a network of orderly changes, unfolding themselves as it were under laws imposed by a lawgiver, laws which we believe to be steady, and in which we trust. A cause is not an invisible something called power, contained in a visible object. It is simply a relation of priority, which the things 
called causes bear to changes called their effects; a relation not of accidental priority, but of invariable priority. The individual things and persons that exist in the universe are in fact all that really exists; for this aggregate comprehends the Divine Being and all inanimate and living creatures. But in all this the conception of power as active and originative, under teleological motives, was absent.

Brown's conception of the universe, akin to what has now taken the name of Positivism, satisfied me at first. It seemed wonderfully to clarify the aim and meaning of science. To search, by observation or experiment, for sequences that are constant or dependable, so as to distinguish them definitely from all mere coincidences, seemed more intelligible than search for an unpicturable ignis fatuus called "power." But by degrees the prospect clouded. I felt, after all, that something was wanting in this unexplained invariableness, somehow accepted in blind trust. How an I justified by reason, when $I$ believe that a sequence in the universe is inexorably constant? It may have occurred a million times, or a million times a million, in past experience; but no one can have 
experienced what is still future. What assurance, therefore, have I that a sequence will be repeated when the (hitherto constant) antecedent makes its appearance again? Do I, a stranger till lately in the universe, know enough about its sequences to warrant trust that any given sequence will be invariable? So Brown's supposed world of constant orderly antecedence and consequence gradually gave rise to a mood of universal uncertainty. The very tie which makes the universe a universe seemed to be loosed.

About this time I met somewhere Hume's 'Treatise of Human Nature.' Through Brown's dissolving view of causation, I seemed bound to surrender to the total doubt of Hume, and the last chapter of Hume's 'Treatise' described the situation. "I am now ready," he declared, "to reject all belief and reasoning, and can look upon no opinion on any subject as more probable than another. Where am I, or what? From what causes do I derive my existence, or to what conditions shall I return? Whose favour shall I court, and whose anger must I dread? What beings surround me, and on whom have I any influence, or who have any influence on me? I am con- 
founded with these questions, and begin to fancy myself in the most deplorable condition imaginable; environed with the deepest darkness, and utterly deprived of the use of every faculty." Nor did Hume's account of his own way of escape from this mental paralysis satisfy me. He thus describes it: "Fortunately since reason is incapable of dispelling these clouds, nature suffices. I dine, I play a game of backgammon, I am merry with my friends; and when, after three or four hours' amusement, I would return to these speculations they appear so cold, strained, and ridiculous that I cannot find in my heart to enter into them any further." But this blind way of appealing to "nature," with scepticism still latent in the heart of nature, seemed a thin and hollow philosophy.

In this uncertainty, having already made acquaintance with the 'Méthode' of Descartes, I adopted his rule for not remaining paralysed in action, although pure reason only admitted doubt. Like him I thought I could not do better than follow meantime the opinions of those among whom I lived; and prefer, among their discordant opinions, the most moderate, as probably the best, since extremes are commonly erroneous. 
In the circumstances I found help and guidance in this Cartesian maxim.

The summer of 1838 was an era in my life. In the preceding winter I had graduated. The examination for the master's degree had introduced me to Sir William Hamilton. In the spring of the year I read an essay in the Diagnostic Society on "Cause and Effect," the subject which then filled my mind. This was the beginning of university companionship ; for shy reserve had hitherto kept me aloof and silent in college coteries. In that summer, too, I increased my acquaintance with Berkeley, and was introduced to Coleridge, besides listening to echoes of Kant.

Berkeley helped to make living mind instead of dead matter prominent. I began to think of the world as rooted in living mind, with matter subordinate; and also to feel the insufficiency of mere invariableness in sequences of events as the final interpretation of causation. The moral philosophy lectures of Wilson had called attention to free agency of intending will, as involved in moral responsibility; thus showing that something more and other than "invariable sequence" was involved in active causation. This was 
ably reinforced by Coleridge, whose 'Aids to Reflection' was a favourite companion that summer, serving more than any other influence to disenchant the shallow causal conception of Brown. Mere invariable antecedence seemed not enough to realise the ideal of an active or veritable cause; an invariable antecedent is not as such responsible for effects: responsible acts must be independent of the necessitation of nature. We all disclaim responsibility for whatever we cannot help being or doing. If I cannot help my volitions being what they are, because I am not their originating cause, I can neither be praised nor blamed for them, nor for their resulting good or bad consequences. The conception of an originating cause, as essentially efficient and teleological, exemplified only in acts of intending Will, was thus beginning to supersede the mechanical conception due to Brown and Hume.

It was in this summer of 1838 that I discovered the two essays of Sir William Hamilton in the 'Edinburgh Review,' on our negative conception of Infinity, and on Perception of what is external. Hamilton was now in the Logic chair. I had heard his inaugural address in November 1836. 
It was on the scepticism of David Hume, which he took as the origin of the great European conservative reaction, seen in Reid's appeal to common-sense, and in Kant's critical analysis of the rationale of human experience; but I heard this with little intelligence. Kant was an unknown name, and the technical terms of his philosophy were to me empty sounds. As early as 1803, indeed, Thomas Brown had given in the 'Edinburgh Review' a superficial and forgotten exposition of the 'Kritik of Pure Reason,' based not on the German text, but on the French translation of Villiers; Stewart's Dissertation on modern philosophy in 1821 contained an unsympathetic ehapter on Kant; this was followed in a more eclectic spirit by Sir James Mackintosh in his review of Stewart. But Hamilton was the first in Scotland to appreciate the historical magnitude of the German intellectual reformer.

I had now completed the usual course of study in literature and philosophy. It was time to forecast a professional career. Devotion to the theological problems of metaphysical thought attracted me to Chalmers, then in the chair of 
theology at Edinburgh, and the most illustrious of Scottish theological professors. In the same year Hamilton proposed to inaugurate a select class for metaphysical devotees, an attractice novelty in the university. A combination of the metaphysic of Hamilton with the theology of Chalmers seemed exactly to suit my case; so, without foreclosing questions about a future career, it was settled that these two were to be my chief studies in the winter of 1838-39.

This new class for metaphysics was the occasion of a public controversy, characteristic of Hamilton, which lasted during that winter and entertained us all. The Town Council of Edinburgh was then intrusted by law with the superintendence of the university, and this expansion of the new professor's work, prompted by his philosophical zeal, had been undertaken without previous sanction by the civic administrators. The Council, jealous of their authority, threatened the professor with an interdict. A prolonged correspondence followed. Letters full of elaborate definitions, and syllogisms worthy of Scotus or Lombardus, were contemptuously hurled by Hamilton at the municipal authorities; all in curious contrast to the simplicity and brevity of the rejoinders by the 
city clerk, in the name of the Council. In the end, while the professor claimed a logical victory, the magistrates were victorious in fact. Unfortunately for philosophy, that winter was the first and the last of Hamilton's special provision for metaphysicians. The "Correspondence" forms a semi-philosophical brochure of forty-one pages.

Being a graduate, I preferred to attend Hamilton's lectures as a private student; with leave to share in work, while not competing for honours. That winter in this class was the happiest in my student life. The lectures attracted a select audience. Never, I suppose, were the ultimate questions about man and the universe, which constitute metaphysics, approached in a Scottish university in a more disinterested and earnest temper than by the band of students then united through common sympathy in the morning of life; inspired by the directing intelligence of one who unfolded before our wondering eyes the ancient, medieval, and modern world of thought. Intercourse in the classroom by day was followed by frequent reunions in the evening at 11 Manor Place, then the abode of Hamilton, where all were encouraged to express difficulties and to debate doubts. I remember one discussion in 
which Sir William engaged, prolonged far into night, in which his own theory, as well as the causal conceptions of Hume and Brown, were under eriticism. I remember his patient responses to crude objections, the issue, nevertheless, of sincere anxiety. I owe more to Hamilton than to any other intellectual influence. He moved us all to think out questions for ourselves. At the end of that winter he gave me a beautiful edition of the philosophical works of Leibniz, of which I have more to say in the sequel.

Two young Edinburgh philosophers, then rising into fame, made occasional appearance at those evening reunions in Manor Place. One was John William Semple, a member of the Scottish bar, whose translation of Kant's 'Metaphysic of Ethics' opened some German philosophy to English readers. Semple was a Greek and German scholar, a lively humorist, with a monomania for the Königsberg professor, and corresponding contempt for homebred "philosophy of the human mind." His death soon after in the West Indies, where he went to recover health, disappointed sanguine hopes. The other weleome interlocutor was James Frederick Ferricr, the most picturesque personality in the succession of Scottish philo- 
sophers, then becoming known as the author of subtle essays on "Consciousness," which were making their way into the world through 'Blackwood's Magazine.'

That metaphysical winter helped me in many ways. It was the beginning of congenial companionship with students, and of the lifelong friendship of Hamilton. At the end the world of the senses had receded; the world of living mind appeared to reduce it to subordinate reality. Causes independent of physical nature began to take precedence of the caused causes that depend mechanically upon certain antecedent phenomena. A dualism, partly suggested by Kant, was now coming dimly into view. There are two things, as Kant saw, which the oftener and the more steadfastly we consider them, fill the soul with an ever-rising wonder and reverence - the Starry Heaven around us, and the Moral Law with its implicates supreme. The Starry Heaven departs from the spot in space which my body occupies, in the world that is realised in sense, and then expands beyond human conception into the Immensity which cannot have limits. Yet when I try to conceive its illimitableness $I$ become involved in innumerable con- 
tradictions, which as it were punish me for making the attempt. The Moral Law departs from my invisible spiritual Self, and reveals an originating activity that is independent of $\mathrm{my}$ animal system, and of the mechanical causation empirically exemplified in nature; and it issues at last in the mystery of teleological instead of mechanical causation finally in the heart of the universe. It was thus that I was led to reflect upon our conception of the infinity that is latent in all that is real. In being involved as each of us is in space and time, we seemed to be involved in a wonderful dilemma. It was impossible to believe either space or time limited: it was equally impossible to understand their unlimitedness. Unless I can rise into Omniscience I must, in this predicament, be satisfice with incompletable knowledge.

It was now, too, that I began to see in our Common-Sense or Common Reason a reservoir which holds for us in a latent state the rationale upon which human action and knowledge at last depend, and which it is the work of the philosopher to interpret. I found this insisted on by Berkeley as well as by Hamilton, although their philosophical interpretations of what 
is implied in the common-sense perception of the material world might seem to disagree; and at one time I was disposed to regard the difference here between Berkeley and Hamilton as more in words than in the implications of their thought. But it was to this Common-Sense, philosophically criticised, that I now began to look for relief in the ultimate uncertainties about the universe in which I formerly found myself a stranger. At first I was apt to confound uninterpreted with interpreted Common-Sense. I was also inclined to ask for logical proof of the trustworthiness of this offered guide. For inexperience is too ready to assume that propositions drawn forth as conclusions from premisses are alone worthy of being received as knowledge.

Above all, I was thus early haunted by a question which Descartes suggested, although his own answer to it seemed to involve a circular fallacy. Do I know enough about the Power supremely at work to be reasonably assured that my faculties may not deceive me? Have I any guarantee that the universe, notwithstanding its present apparent natural orderliness, may not finally turn out to be a chaos which a deceiving Supreme Power is imposing upon me? Here Descartes 
found relief in the argument that God is no deceiver, and consequently cannot permit error in the foundations of human belief. So he might safely infer the truth of nature's dictates. This was put by Descartes as an inference. It seemed to involve a circular fallacy. Suspected faculties in a suspected universe cannot be trusted to demonstrate the goodness of the Supreme Power. Not seeing my way here, I continued to adhere to the other maxim of Descartes already mentioned. I accepted provisionally inherited convictions, and adjourned the endeavour to justify to reason my faith in the moral trustworthiness of the Power that is universally at work.

In this and the four following years I looked much to Chalmers for light on the foundation of our beliefs, especially those involved in natural theism and Christian theology. Two men more remarkable than Hamilton and Chalmers have never, I suppose, occupied chairs simultaneously in a Scottish university. Hamilton was perhaps the most learned Scot that ever lived; he was also able to resolve abstract principles into their consequences, and to redargue objections, with the elaborating subtlety of a medicval School- 
man. Chalmers atoned for comparative mediocrity of learning by the cloquence and moral fervour with which he delivered magnificent conceptions, and diffused a fresh glow of intellectual light and spiritual life through the frozen orthodoxy of Scotland. The restrained rhetoric and grave eloquence of Hamilton, his rigid economy of well-measured language, delivered in the classroom word for word from manuscript, in defect of easy command of extempore expression, was a contrast to the brilliant effusiveness and fervid, if sometimes superfluous, iteration of his illustrious theological colleague. The theology of Chalmers was coloured by the philosophy of Brown, which had dominated in Scotland in the two decades that preceded and followed his death in 1820; but Brown was the bête noire of Hamilton, who pursued him with relentless logic as a faithless representative of the tradition of Reid.

Notwithstanding moral reverence and personal enthusiasm for the man, I somehow failed to find in the lessons of Chalmers the expected satisfying settlement of perplexities of religious thought. It was so as to several articles of his philosophical theism. To rest belief in the existence of God upon the total absence of historic record of 
the existence of the world prior to the Book of Genesis, was surely a slender basis for the infinite conclusion. It seemed to imply that the fundamental fact or principle of all religion depended upon empirical proof that the world had a beginning; although the inconsistency of theism even with an unbeginning universe seemed not self-evident. On the other hand, the irrationality of dogmatic atheism as the creed of a finite intelligence was curiously illustrated. The attitude of those who are now called agnostics was viewed even with complaisance, as a step towards faith, although not the final position. Yet it was difficult to sympathise with this provisional agnosticism, as a hopeful beginning. Dogmatic atheists were pressed to hold provisionally in suspense their dogmatic conclusion that there is no God-on the empirical ground that although God may not be found on this planet, or even on any of the orbs of our solar system, He may, for aught we can tell, be found on one of the innumerable stars or planets that occupy immensity. One was apt to think that a God thus located could not be the omnipresent and omnipotent Power in whom the universe has its being. Then, too, an inductive inference of the perfect goodness of 
the Supreme Power, on the basis of our experience on this planet of a strange mixture of evil and good, seemed to involve the fallacy of resting an infinite conclusion upon a finite experience involving contradictory facts. When the solitary datum is a suffering and morally disordered world, how can we infer from this an omnipotent and perfectly good God? This paralysed some postulates in the natural theology of Chalmers; nor was full relief got from Bishop Butler, or from Jonathan Edwards, two theological heroes of the professor.

Butler's reverential submission to reality was always refreshing. "Things are what they are; why then should we desire to be deceived?" His constant refrain of Supreme Moral Power in the heart of things was the expression of profound yet troubled faith. But the attempt to release Christianity from the pressure of intellectual and moral difficulties, by arguing that similar difficulties are found in abundance in the universe itself, as presented in our ordinary experience, was apt to aggravate instead of relieving the theistic perplexity. For the fundamental difficulty was, the existence in the universe of 
the very facts to which Butler's analogical argument appealed for relief. He who asks for reasonable justification of faith in the goodness of the Power universally at work, in a world in which sin and suffering abound, is not induced to accept a professed remedial revelation because it multiplies the lurid facts. Such analogies strengthen instead of weakening the position of an agnostic, to whom the universe is "a riddle, an enigma, an inexplicable mystery"; with "doubt, uncertainty, and suspense of judgment" the only result of our scrutiny into the origin, meaning, and destiny of human life.

I found more lasting satisfaction in Butler's deep sense of the inevitable final ignorance of man. This ignorance disables him from rejecting absolutely propositions which (through the demonstrable finitude of his intelligence and experience) can be only incompletely understood; but which, nevertheless, may be sustained in faith by the spirit that is in man. What a finite intelligence can only imperfectly comprehend, must be distinguished from that in which even finite intelligence finds express contradiction. Man may accept the mysteries that are involved in intellectual finitude; but he 
cannot, under any conditions, accept what he clearly perceives to be irrational. This logical maxim opened the way, I thought, to a larger conception of intellectual and moral possibilities in the constitution of the universe. It encouraged a larger conception, too, of the domain of "law" in the universe than either ordinary science or dogmatic theological systems were accustomed to assume. Mysteries, including those involved in Christianity, might disappear under the light of reason, if our intelligence could carry us fully within the "supernatural" order, to which the empirical cosmos discovered by inductive experience of external nature is subordinate. I found Butler himself countenancing this. In a remarkable paragraph of the 'Analogy,' he supposes that "there may be beings in the universe whose capacities and knowledge and views may be so extensive as that the whole Christian dispensation may to them appear natural-as natural as the visible course of things appears to us." Whether the intellectual progress of mankind in this mortal life can ever reach this ideal may be considered by any who anticipate human Omniscience as the possible goal of human progress. 
We were told by Chalmers that Jonathan Edwards was the "prince of modern theologians." Yet the wholly necessitated universe of Edwards seemed to resolve the wicked volitions of persons into necessitated sequences, thus making an evil act an effect for which the apparent agent could not be responsible. Nerertheless this NeoCalvinism was gladly accepted by Chalmers, as relief under theological difficulties. Assuming the necessary universality of mechanical causation, Edwards argued logically enough that all moral and immoral acts, like other events in nature, are produced in us by natural antecedents, and could not originate finally within the individual person to whom they are attributed. On the other hand, one asked how a person could justly be responsible for volitions, whether called good or bad, which he could not help having, because they did not originate in his intending will. Edwards proposed an answer to this question which satisfied Chalmers. The goodness or badness of a volition lies, we were told, not in its origin but in its quality, as felt by us after it has been produced. The taste of an apple or the colour of a rose are what our senses feel them to be; and are what they are, without 
regard to the causes which have made them what they are. In like manner human volitions, Chalmers argued, are good or bad according to our feeling of what they are; with as little regard to their origin as in the case of the apple or the rose. We call a man "wicked" if, by an intending act of will, he has committed murder; but this because the quality of the volition is offensive to our moral sense, and not because the act supernaturally originated in the man: it was the natural issue of his inherited organism. The unhappy subject of the rolition naturally suffers for its badness, and questions about its origin were dismissed as irrelevant or meaningless.

If $I$ accept this, I was apt to ask, Am I not adopting a conception of human activity which empties it of moral character? How can a volition, which I could not help having, be justly attributed to me as personal sin? A person who was the subject of an evil volition might feel regret, but how could he feel remorse? An "agent" who could be justly blamed must surely be more than a passive conductor of causal influence. Moral responsibility for "acts" that were determined independently of the so-called agent 
must disappear; and along with this, by logical necessity, all moral government of the living portion of the universe. It seemed impossible to distinguish the position of Edwards from that of Spinoza, expressed in the language of a different school. But some perhaps see in these objections, strongly felt at the time, only the rash conceit of inexperienced youth.

Sin and guilt inherited on account of the misdeed of another, accordingly, seemed to remain a difficulty, not got rid of at least by this expedient of Edwards. For it appeared to contradict the moral axiom that individuals cannot be responsible for what they did not originate. That the human inhabitants of this planet fail to reach the divine ideal of goodness was a fact of experience; but then this way of accounting for the fact seemed to absolve them of responsibility for it, by making sin a physical disease, naturally transmissible. Also the endless existence of wicked persons, implied in endless punishment, was a mystery which the philosophy of Edwards seemed to aggravate, by making the conversion of a few of them to goodness the issue of arbitrary divine selection, instead of a universal divine lore. Faith in omnipotent good- 
ness seemed (at the Calvinistic point of view at least) to imply faith in restoration to goodness of all persons in the universe who were bad; and this not because the bad deserve happiness, but because the endless existence of wicked persons is inconsistent with hostility to moral evil in the divine determining Agent. The wickeder persons are, whether men or devils, the more certain it seemed that God, who is perfectly good, would make them good-either by sudden conversion or by a gradual process. Indeed the endlessness of wicked persons, not the endlessness of their suffering, as long as they continue wicked, has always been my difficulty.

The mystery involved in Deatl, and in a second endless life for men after their physical death, were much in my thoughts in those years with Chalmers. Emergence at birth as strangers in this world of sense; conscious life on earth conditioned by our bodies; emergence again into self-conscious life unconditioned by conceivable embodiment, when the present body is dissolved, were conceptions fruitful in questions. I remember Chalmers expressing with characteristic vehemence his indifference to speculations of 
this kind, and how he disclaimed sympathy with his "friend" John Foster, the eminent English Nonconformist essay-writer, "for whom distasteful speculations about the dead had a fascination." Somehow the fascination seemed less unnatural, if less healthy, than indifference. I used to put the case to myself in this way. If I knew that in the near future $I$ was to be transported to the most inaccessible spot upon this globe, to remain there till I died, it would surely be natural to me to forecast this prospect. With a more solemn interest I would naturally look forward to being transported, still in the body, to another planet in our solar sphere; or, more mysterious still, to a planet in another solar system. But how insignificant even this last imagined exile from my present home, in comparison with continued self-conscious life and experience, after cessation of sense relation to the material world, in a more than ghostly life of spiritual disembodiment. Was it ummatural to forecast this prospective miracle of finding myself alive after I have died? So I sought for light. Isaac Taylor's 'Physical Theory of Another Life' came in my way, and attracted me to the author; for his "theory" interested 
me by its ingenuity, although it seemed too "physical" in its postulates.

Such were some of the aspects in which the enigma of the universe, and of human life-that gleam of self-consciousness between two eternities - presented itself to me in years that were fruitful in "obstinate questionings of sense and outward things." The questioning was perhaps excessive, and activity of intellectual digestion out of proportion to the amount of food that had been collected in experience. But Bacon says that "the registering of doubts saveth philosophy from errors; the entry of doubts being as so many suckers or sponges to draw increase of knowledge"; and I sometimes found this true.

Hamilton encouraged us to raise questions, as well as to discuss freely with him his own speculations and those of other philosophers. Chalmers, I think, was in this respect hardly so indulgent, and perhaps some of us transgressed the limit of toleration. Our metaphysical studies had brought us into contact with Kant and Fichte, and this led to our adoption of a philosophical dialect, and also of Kantist and Neo-Kantist 
points of view, which were strange to his Scottish philosophy. So years afterwards, in one of his prelections as Principal of the Free Church College, he referred thus to this state of things: "For those who are not inclined to study German philosophy, I do not recommend that they should suspend for it their ordinary readings. Their very ignorance of the German idealism, the very confinement of their mental philosophy to the doctrines and metaphysics of the Scottish school, are guarantees in themselves against the deleterious influence of these outlandish speculations. I do recollect of some students who, beforc our Disruption, were a good deal carried, as if by a sort of fashionable infection, which might have been seen in the phrascology of their discourses; and who, however mortifying to one's self-lore, gave forth the symptom which I am now about to describe, in their obvious inattention to the lessons of the chair, as if they had only been plain Scottish boluses, having vastly too much in them of the homely and the commonplace to be at all suited for these high appetencies which nothing else can satisfy but the more exquisite and recherché articles of a forcign preparation; just as if we had becn serving up milk for babes instead of strong 
meat for men of a full understanding, or were speaking from the outer court to those who had already been initiated in the mysteries of the inner temple. What I want to make out is that the unintelligible does not alway imply the solid or even the profound ; and, far more momentous than this, that the simple verities of the Christian faith rest upon a foundation strong enough to uphold them against the ever-shifting philosophy that now sets in upon us from abroad." This expresses then prevailing Scottish sentiment, especially ecclesiastical, to aspects of philosophical thought which are now welcomed in the ecclesiastical world of Scotland. They also illustrate the attractive simplicity that marked the noble genius of Chalmers.

In the years after 1838 the awkward reserve, that was encouraged by years of seclusion on the isolated peninsula in Lorne, gradually abated, in the society of young men who largely moulded my education. I met them in Societies organised for discussion-then the chief opportunity for familiar intercourse among Edinburgh students, and always a valuable factor in its academical life. My earliest friend outside the manse 
was Robert Couper Black, with whom I was intimate as early as 1835, when we lived in the house of our Edinburgh tutor, Doctor James Gardner. Black was an enthusiastic admirer of Coleridge and Kant. Our discussions in walks in spring in the Meadows did more for my philosophy than Ritchie, or even the discursive eloquence of "Christopher North." Black and I were joint presidents of a Metaphysical Society, which was formed in 1838 by Hamilton's select class for metaphysical devotees. Indifferent health frustrated a philosophical career that was full of promise, and shortened a life that was latterly devoted to God in the Church of England.-Another of my benefactors was John Cairns, a massive and masterly thinker, eminent among all Edinburgh alumni of the nineteenth century, whose speculative power was held in restraint then, and more in after-life, by the superior attraction of philanthropic endeavour to promote divine life among men through the Church - in the end Principal of a Theological College. A purer and nobler character I have never met.-There was also James Walker, abundant in dogmatic vigour and fruitful suggestion, although in after-life ill health, and 
confinement of energy at Carnwath, left the world ignorant of a strong personality. Along with these was William Welsh, later on the genial pastor and laird of Mosfennan; John Nelson, afterwards a doctor of divinity in the Free Church of Scotland; and William Garden Blaikie, one of its professors. To George Wilson, later on professor of Technology in the university, and Samuel Brown,-both chemists of metaphysical genius,-and Daniel Wilson, versed in archæology, afterwards Sir Daniel Wilson, President of Toronto University, I was then gradually approximating; intimacy came afterwards. Death has taken them all away. One remains, long in the front rank: David Masson was the most striking figure among those who then listened to Chalmers; his brilliant career since is known to the world. His friend Alexander Bain, since eminent as an Aberdeen professor and in the history of British psychology, whom the world has lately lost, was at that time in Edinburgh and much in our companionship, though not an alumnus of Edinburgh. All of them I recollect with a romantic interest. Deep questions debated in the morning of life, with the sanguine naïveté of youth and inexperience; ready to return with hope to the encounter after 
each repulse; none of us much alive to utilitarian considerations or to policies of parties.

Most of them worshipped Thomas Carlyle. When the Chair of History was vacant in 1842 there was a movement among the students, led by some of my set, to have it offered to Carlyle; but in the end it was given to Ferrier. I was then untouched by Carlyle: Coleridge, Wordsworth, and Newman had been my heroes; the 'Aids to Reflection' and the 'Excursion' took the place of 'Sartor Resartus' and the 'French Revolution.'

In 1841 "Toleration" was announced as the subject of essay for the year for the University Prize, which the students were in those days annually invited to compete for. The subject suited my state of mind. It was in harmony with my strongly felt revulsion from the lack of charity apparent in the ecclesiastical controversies which then disturbed Scotland; and it was also akin to habitual thoughts about the finitude of human understanding, the very rarious degrees of individual intelligence, and the narrow opportunities for experience, that are within reach of mankind. The summer of that year was accord- 
ingly much given to the society of John Locke and Jeremy Taylor, and to meditations which have left their mark upon my life.

How ought persons differenced as we all are, to behave themselves towards those who profess beliefs contrary to their own? and how ought State and Church to treat members of their respective societies in this regard? Was it their duty to restrain inquiry, or to punish inquiring men, for professing religious beliefs that were perhaps inevitable at their point of view? Would restraint of this sort at all help the victories of truth under the actual conditions of human life? On the contrary, when life is looked at from the individual point of view, does it not appear that duty to truth demands social security for outspoken exercise of each person's share of reason, left to be determined by evidence alone? Is it not in this way that individual errors or half-truths, by correcting one another, gradually extend our knowledge; the one-sidedness of each man giving place to the many-sidedness of authoritative mankind? These were some of the questions I found involved in Toleration. "Justitia, et veritas, sed in omnibus caritas." "We all have 
erred: men may, I find, be honest, though they differ." Lessons like these I was now assimilating.

A difficulty which embarrassed me was, how to reconcile toleration of individual belief and individual conscience with the social cohesion of either Church or State; also the just relation between Church and State. The "religious equality" claimed for individuals seemed charged with elements of social disintegration and anarchy. If States or Churches must be limited in legislative action by the judgments of their individual members; if no law can be justly enacted by the State that is inconsistent with absolute equality in its treatment of all the consciences that are alive in the community-must not this lead to paralysis of government, or at least to the abnegation by the State of all its higher functions? And are elaborate articles of faith consistent with progressive exercise of reason by each member of the Church? A great national $\mathrm{or}^{\circ}$ a great ecclesiastical community must include discordant opinions, - conformist conseiences and nonconformist consciences, - and if the action of the social organism ought to eonform to the moral judgments of all its individual members, little room seems to be left for organic action. 
To maintain religious equality must not the State be wholly neutral or agnostic in its relation to the religions of the world?

The duty of toleration in religion and in politics was an undereloped novelty before the middle of the seventeenth century, although the idea of religious toleration has been traced in germ to the Council of Toledo. Intolerance, whether in theory or practice, is no distinctive peculiarity of the Roman Church, which indeed might maintain its spiritual claims without using this instrument to support them. Scottish presbyterians were later in acknowledging this part of social ethics than conformist and nonconformist Englishmen. The "Larger Catechism" of the Westminster Assembly includes "toleration" among sins forbidden by the second commandment. John Owen, the Independent divine, was a warm advocate of religious toleration, but on grounds different from Chillingworth and Jeremy Taylor, or even from Locke, who "esteemed toleration to be the chief characteristical mark of the true Church, as it is of that faith which works, not by force, but by love."

I am sure that these questions were not treated in an adequate manner in my essay, but the 
favourable award of the judges was an encouragement at the time. The controversy then active about the morality of support given to the Christian Church by a Christian State, followed by actual collision of the Church with the State in Scotland-in which I now found myself as a student of theology in a manner involved-infused reality of life into speculative arguments about religious Toleration. The subject was a fit prelude to the ecclesiastical storm which raged around me during the next stage of my journey. 


\section{CHAPTER III.}

\section{AN ECCLESIASTICAL DIGRESSION.}

\section{$1842-1846$.}

"Nothing doth so much keep men out of the Church, and drive them out of the Church, as breach of unity."-Bacon.

IN 1840 and 1841, contemporaneously with the prelections of Chalmers, I attended the lectures of David Welsh, the Professor of Church History. Welsh was an acute and sagacious analyst of the human mind, inclined to the philosophy of Thomas Brown, in alliance with the phrenological psycho$\log y$ which was then fashionable in Edinburgh. He was neither deeply learned nor much endowed with historical imagination; but he was ecclesiastically candid and inquisitive, liberal in politica] sentiment, and tolerant in religious belief, while firmly established in his own evangelical creed. I was attracted to him as the friend and affectionate biographer of Brown, whose book on causation had been so considerable an influence 
in my early education. I was first introduced to Welsh on one of the evenings at Sir William Hamilton's in Great King Street. Notwithstanding keen controversial hostility to Brown, and other differences, Hamilton and Brown's biographer were close allies. I used to meet them in their walks together in the environs of Edinburgh.

Ecclesiastical interest had been awakened in me before I began to study the history of Christianity and the Church systematically in the academical class-room. The story of the advent and gradual extension through the ages of a revelation of God, that claimed to have entered into human history by ways beyond "nature," in the ordinary meaning of that ambiguous word, and which also promised practical relief under the distressing pressure of the mystery of human life, was congenial to my state of mind. The Church, as the visible organ of an extraordinary operation of God in the history of our planet, promised to provide a muchneeded director in the search for certainty in matters of religion.

The attraction first came to me from the contemporary condition of the Church of England. I had been more or less interested in the "Oxford 
movement" almost from its beginnings in 1833 . The 'Record' newspaper, representative of Anglican evangelicalism, made its way to the manse, in addition to the 'Courant.' Through its hostile criticism I became in some degree familiar with the 'Tracts for the Times.' But in the end the 'Record' repelled me from itself more than from the 'Tracts.' I disliked its dogmatism. Besides, sentiment and fancy were touched by the ideal of Christendom united in the historical continuity of its visible Episcopal developmentRoman, Greek, and Anglican. 'The idea seemed to enlarge and glorify the individualism of Clapham evangelical life, inherited from Moravians and Methodists, that had been favoured in my early training by my mother. Newman, who tells us that he was one of the founders of the 'Record' in 1828, was now the inspired leader of the Anglo-Catholicism which the 'Record' denounced. Gradually I began to see in the Church of England a via media; in continuity with the undivided Church Visible, patristic if not medieval, yet with room for those well affected to the doctrines of Geneva - a Church Catholic yet Protestant-unique in Christendom. It had a sort of fascination. There was risk of disrup- 
tion, no doubt, when the opposed factors were in full spiritual life. Temporary adjustment of the conflicting elements formed the Elizabethan settlement; followed by fresh conflict in the Great Rebellion, and resettlement at the Restoration, with expulsion of "the sectaries" and consequent rise of Anglican Dissent,-all threatened now by demand for "religious equality," in a nation no longer identical with its historic Church. Is disintegration inevitable under the strain, or may Anglo-Catholicism even become the reconciling medium in a united Christendom?

I was revolving questions of this sort in a crude way when I was in the church listory class. Welsh's lectures were hardly in touch with this state of mind. He seemed to disparage unduly the hierarchical historic Church which had conquered Pagan Rome, maintained itself through the rise and fall of empires, and was still standing before the world as the visible guarantee of Christian faith and life. He described its record as one of gradual departure from apostolic purity into spiritual despotism and ecclesiastical corruption, culminating in Hildebrand and medicval Romanism; instead of the gradual evolution of a divine organisation which 
benefited the world. The history of organised Christianity for fifteen centuries was pictured as a history of the growing unfitness of the organism for transforming morally disordered humanity into a spiritual kingdom, in which the tremendous mystery of human life was to receive its practical solution. This disastrous ecclesiastical evolution, we were told, was followed in the sixteenth century by a cataclysm-a revolutionary return to original simplicity and purity, in those parts of Western Europe which then separated from the Roman organisation, and multiplied as independent sects; rival and competing, according to the various interpretations they put upon books of ancient authorship which were accepted as infallible.

This interpretation of the fortunes of the Visible Church throughout the centuries was perplexing. About 1840 Ranke's 'History of the Popes' and Macaulay's brilliant criticism attracted me. The hierarchical Church of Hildebrand, under which pagan Rome was transformed into the more comprehensive empire of Christendom, seemed the most majestic and persistent of human institutions, with its record in a long succession of self-sacrificing saints and 
missionaries, who exemplified and extended the religion which they professed. The ancient universities of Europe were evidence of its zeal for learning, and its members were illustrious in the literature of theology and philosophy. The 'Summa Theologiæ' of Thomas Aquinas took its place beside the 'De Civitate Dei' of St Augustine and the 'Institutes' of Calvin, as magna opera of Christian theology; like those of Aristotle, Spinoza, and Hegel in the library of philosophy. Aquinas, indeed, was one of my favourites at this time, and in the face of opposition I got his works, in some twenty-eight volumes, into the theological library of the University. And in modern philosophy, I had found no books more congenial than those of Malebranche, Arnauld, Fénelon, and, above all, Pascal, representatives at once of spiritual philosophy and of Catholicism in France.

It was during one of those winters that with my friend Walker I went to hear some lectures by Dr Gillis, the Roman Bishop of Edinburgh, given on Sunday evenings in the Catholic Church in Broughton Street, in rejoinder to the strictures of Macaulay on the Papacy in his "Ranke" article in the 'Edinburgh Review.' The lectures 
checked instead of encouraging any disposition to look for the basis of religious certainty in the fallible hypothesis of an infallible ecclesiastical organisation. The promised certainty had to be reached, as it seemed, through an avenue of uncertainties. I ventured to express some of these difficulties in an anonymous letter to the bishop, which he good-naturedly made the subject of criticism at his lecture on the following Sunday.

The spirit of Descartes and Locke, as well as meditation upon the duty of private judgment, as our final resort, - in connection with the essay on "Toleration," - were now dissolving my ecclesiastical dreams in a return to the modern temper, after an aberration chiefly due to the poetry of religion, of which the medieval spirit was full. The former disposition to welcome an ever-at-hand infallible authority in religious controversies, which discordant Christendom seemed so much to need, was checked by reason. It was, indeed, one phase of the craving for certainty, religious or other, in the presence of the awful enigma of the universe, by which I was haunted.

I was now invited to apply reason to another 
claim for infallibility. The essay on Toleration was hardly out of my hands, when the theological professors proposed a vindication of the infallible authority of the Bible, for the subject that year of the Pitt Prize essay, then annually open to competition among theological students. The subject seemed in natural sequence to questions raised by Toleration, and likewise to recent interest in the claim of ecclesiastical organisation to divine inspiration and consequent infallibility. Books produced long ago in Judea had, in the sixteenth century, exclusively taken the place, in the Teutonic and Anglo-Saxon world, of the continuous ecclesiastical inspiration to which Europe had looked, as the basis of religious certainty, in the "ages of faith." What could be said in favour of the infallibility of this collection of revered books, as a substitute for the abandoned infallibility of the living Church? I was attracted by the question, and some of the following summer was devoted to the essay. I did what I could to unfold the rationale of faith in Scripture, as the ultimate ground of certiinty in questions of religion, a dogma that was pressed with emphasis in the lectures of Chalmers, and in books of popular Protestantism within reach in 
my seclusion at the manse in Lorne. My essay, presented in winter, hardly touched the root of the great question involved, and as it obtained the prize, the other competitors must have been slenderly endowed.

The infallibility of a series of books, written long ago, ostensibly by fallible men, taken in these latter days as the ultimate criterion of religious truth, doubtless affords wider room for the interpreting judgment of the individual than that afforded by a living infallible authority, constantly at hand to direct us all; but this with greater risk of erroneous interpretation. The dead book, open per se to innumerable varieties of interpretation, is otherwise provided with an infallible interpreter always ready to correct individual mistakes, and to guide the faithful. The loss of this ever-present resource explains the horror with which the Protestant watchword of "the Bible alone the religion of Protestants," when first proclaimed, was regarded by Catholics, and the tragic aspect of the revolution in the sixteenth century, which seemed to throw mankind hopelessly back upon the final mystery, which the Church had been supposed able to relieve. 
Infallible fundamental assurance, so it seemed in the end, could be secured neither through an inspired Church nor an inspired Book, if it was rested in either case only upon historical evidence. I can be no surer of what I prove than I am of the evidence which is supposed to prove it. Historical evidence gives only probability. Even proved physical miracles are not an absolutely certain foundation, as long as the moral character of the Supreme Power in the universe is uncertain; for then the miracles may be meant to mislead us. Christendom, too, is divided among various sects, and which sect is invested with infallibility? The books of Scripture present an analogous difficulty; the canonicity of each constituent part is open to doubt and criticism. What books in Jewish and Christian literature are infallible? Above all, the inspired Book, and even the dicta of the inspired Church, must be interpreted. That interpreters are apt to err is evident in the innumerable variations of interpretation. It seemed, then, that neither the living Church nor the dead book could be the final and exclusive foundation of religious certainty. Each needs to rest on something deeper and more comprehensive. Hooker, who was one 
of my favourites at this time, seemed to show conclusively, as against the Puritans, that neither Church nor Book could be ultimate, or the sole reservoir of religious knowledge and divine revelation. Either must presuppose the co-operation of other factors of theology. When included in a wider philosophy, both may be of immense practical value; but the reasonableness of faith in either needs vindication, and this carries us back to faith in the perfect goodness of the Power dominant in the universe. "Unto the upright there ariseth light in the darkness." Intercourse with men in the endeavour to make them good, seemed in the meantime my practical way of gaining spiritual light and life.

The essay on Biblical Infallibility had brought me much in contact with Chillingworth, and I found congenial thought and temper in Cudworth and other Cambridge Platonists, as well as direction from Hooker.

In 1842 I spent part of the summer in England, realising early dreams, and enlarging a very provincial experience. One of my brothers had been offered an Indian cadetship, and I went with him and my father to London. After parting from them 
there, I made a solitary pilgrimage to Oxford and then on the Continent. We travelled to London in the steamer from Leith, and I can recall the enthusiasm inspired by the scenery of Kent and Essex in ascending the Thames in the sunshine of an English summer morning, the landing at Blackwall, and the interminable seven miles' journey through crowded streets, under a sultry sky, to Bloomsbury, my headquarters in London, in the house of my mother's early friend, a sister of the late Sir Edward Ryan, whom we had come to visit.

London of that day was still the Old London of the Georgian era, little affected by the social forees which have transformed it during the reign of Queen Vietoria. It was before the era of palatial hotels, and even the omnibus was then a novelty. I remember Sir John MacDougall, a few days before we left the Land of Lorne, describing as a wonder this new means of locomotion, of which he had some experience a few months before in the metropolis. My first ramble in London was on the day we landed. It was from Bloomsbury to St James's Park, through the once famous Seven Dials. As it happened there was eommotion in the Park. It was the after- 
noon on which Francis fired at the Queen, as she and Prince Albert were driving on Constitution Hill.

In London I found chief attraction in Westminster Abbey and in the Houses of Parliament. The Abbey seemed to embody the romance of English history in Church and State to which I had been introduced in old days at the manse, and its mysterious proportions and dim religious light awakened a response that was unfelt when I visited St Paul's.

The existing palace of the Legislature at Westminister was then only a project, and the old historic houses had been destroyed by fire a few years before. Almost my first evening was spent in the House of Commons. It helped to satisfy a desire awakened long before, by reading debates on Catholic Disabilities and the Reform Bill, and by watching in the solitude of Benderloch the fortunes of Lord Grey and Lord Melbourne. The mean appearance of the temporary home of the Legislature was unexpected, but the personalities were an absorbing interest. On that first evening I heard Sir Robert Peel, then Premicr, and Lord John Russell, who led the Opposition. Peel's fluency, dexterity in debate, and command 
of the House were memorable-in his light waistcoat, and watch-chain with its conspicuous bunch of seals, as I now see him in my mind's eye, as well as the moral strength in physical lassitude of Lord John;--umpretentious oratory and utilitarian common-sense in Joseph Hume; voluble argument of Roebuck, the philosophical Radical; and the massive head, genial face, and reckless humour of Daniel O'Connell, the Irish Liberator, - are still rivid memories of this first night in the House of Commons. But of all the speakers my chief interest was in Gladstone. I was already familiar with his book on Church and State, and with Macaulay's certificate, that he was a "young man of unblemished character, the rising hope of the stern and unbending Tories, who follow reluctantly a leader whose experience and eloquence are indispensable to them, but whose cautious temper and moderate opinions they abhor." Gladstone's speech at the Glasgow banquet given to Peel by Scottish Conservatives in 1837 was not forgotten by me, with its condemnation of proposals to dissolve the union with Ireland, or to reduce the Irish Church establishment. His youthful countenance, handsome figure, fervid earnestness, and the music 
of his voice,-are all associated with that memorable evening.

A week of beatitude in Oxford more than realised the Oxford vision of preceding years. It was to me the most notable event in the history of that summer. Less than two hours on the Great Western carried me to Steventon, and another hour by coach to Oxford, on a sultry afternoon in June. This was followed by an evening in Worcester College and its pleasant garden, my Oxford home during this Commemoration week, when I contemplated the city of colleges from day to day, in the radiance of a perfect English summer. The picturesque life of the place was invested with a halo of medieval romance and poetry. For the first and last time I saw Newman. He was standing in a crowd in the old quadrangle of the Schools, on the day of the meeting of Convocation which censured Hampden. The atmosphere of Oxford in 1842 was densely charged with Newmanism, and the 'Tracts' had formerly brought me for a time under this influence. Reverence led me to touch the hem of his academic robe. $\mathrm{He}$ was then living at Littlemore, and three years later he went over to Rome. I always regret that I 
missed an opportunity long years after of visiting him at Birmingham. Pusey, Keble, and Palmer were also among the historie figures seen on that far-off summer day in the Oxford quadrangle. My personal intereourse was confined to undergraduates. Through my Edinburgh friend Black, now resident in Oxford, I was introduced to Burgon, then an undergraduate at Worcester, afterwards the genial and eccentric Dean of Chichester, whose continued friendship was a happiness in later years. Another interesting personality I found in Henry Skeffington, brother of Lord Massareene, a fervid Newmanite, inspired by faith in the supernatural authority and continuous life of the Visible Catholic Chureh, with its saeramental symbolism and regenerating efticacy, as the noblest of social organisations. I was attracted by the beautiful enthusiasm of this young man in our walks around Oxford, and in his correspondence after I left the place, to see him no more. His early death four years later disappointed sanguine hopes.

It was with a heavy heart that on the day following the Enccenia in the Sheldonian Theatre I saw the colleges and towers of Oxford disappear, when I was returning on the coach to London. I 
would gladly have made the fascinating city my home, but I saw no way open; and, indeed, the farewell seemed final. The railway was then a novelty. I remember how my father, accustomed to the quiescent isolation of Argyllshire, had advised me to profit by this experience of England, as it would probably be the only English experience of my life. Yet I have visited England some sixty times in the intervening sixty years; and I could not then foresee the ties which, in ways unexpected, have in later years connected me with the most beautiful academic city in the world.

After leaving Oxford I made a short solitary excursion to Belgium and the Rhine. Sweet Bruges, a summer day in stately Ghent, followed soon after by a Sunday devoted from early morning till late evening to church services in Cologne, are among its lasting pictures. A day at Bonn was devoted to the university; but Bonn was to me under an eclipse caused by pathetic remembrance of the glories of Oxford. I wandered into the church history class, where I heard with imperfect intelligence a German lecture on Hildebrand. It was followed by another on Xenophon, by the venerable Brandis, addressed to an audience of about sixty. The unbroken stillness of the 
students was a novelty to one accustomed to unrestrained demonstrations in an Edinburgh lecture-room. Of the return journey I recall a night on the deck of the steamer between Cologne and Rotterdam. Under the light of a full moon, I watched in solitude the windings of the Rhine, through scenes curiously foreign, which somehow revived strongly that sense of the foreignness of all experience on this strange planet, that had so often haunted me at home. The sight of Holland from the summit of a tower in Rotterdam was tantalising. The country was for me associated with Descartes, and Locke, and tolcration; and this transient outlook was attractive. But my finance was exhausted, and Holland remained unexplored for more than fifty years. The house in which Erasmus was born, and his monument on the Boomjees, was an interest in Rotterdam. In those days I was apt to sympathise with the ecelesiastical policy of Erasmus.

I returned to the land of Lorne when Seotland was in the crisis of an ccclesiastical conflict, which in one form or another had been going on for nearly ten years. None of the parties engaged 
in it were guilty of the sin of Erasmus; the perfervidum ingenium Scotorum was conspicuous in all. Ecclesiastical war had arisen in Scotland contemporaneously with the Anglo-Catholic revival in Oxford in 1833. Each was at first the issue of revived religious life, in reaction against the increasing secularism or religious agnosticism of the State, promoted by ideas of political and religious equality that were born of the French Revolution. After our political Reform in 1832 , these ideas threatened the ecclesiastical establishments of England and Scotland, which were regarded as inconsistent with equality in religion. The eeclesiastical revival came in both cases from the seventeenth century, inspired in England by Andrews and Laud, and in Scotland by Henderson and the Covenanters.

In Oxford Newman had recalled the Church to a sense of its supernatural strength, conveyed through apostolical descent, and consequent community with the one continuous divine organisation in Christendom; while it was nevertheless the religious organ of the English nation in protest against the claims of the Bishop of Rome. In the early Thirties the Church of England seemed to Arnold immediately doomed as an 
establishment. The Oxford ecclesiastical revival falsified the prediction. In Scotland ecclesiastical life under Chalmers was Puritan in spirit, and not yet politically democratic, indeed strongly conservative in temper. Indifferent to the modern theory of religious equality, and its consequent, national religious neutrality, Chalmers regarded the highest welfare of man as the common end of State and Church, and saw in the establishment of a Church by the State, a relation in which the superior religious wisdom attributed to ecclesiastics was sustained by the superior secular resources of the Christian State; but with these two factors of human progress still related as allies, absolutely independent of each other in their spheres; not identified, according to the ideal of Hooker, in which the Church is the Christian State in religious action. But while each was independent in its own department, a religious establishment was with Chalmer's indispensable for making the ministrations of the Church territorially coextensive with the increasing population of the nation, as well as for checking the growing religious neutrality or indifference of the modern State. This raised in Scotland what has been described as "the hardest 
of all human questions "- the right relation of the nation to the aggregate of religions embraced within its domain; a problem ultimately akin to that of body and soul in man, or of nature to spirit in the constitution of the universe.

Against this idea, what was called "Voluntaryism" tended to total secularisation of the State. It was argued that an adequate fulfilment of the national duty of religious toleration forbids national encouragement of any of the competing or conflicting sects into which modern Christendom has transformed itself, as unjust to the others, and to all who are outside Christendom. Friendship to one was hostility to the rest: a perfectly tolerant State must as such be equally friendly to all religions, or, rather agnostically equally indifferent to all. Action by the State, it was argued, cannot be truly spiritual action : national legislation involves physical compulsion, while religion appeals to individual freewill, and ought to rest upon this as the only legitimate motive for sustaining and extending itself. Even if Christendom, united in One Catholic Church, were to include the whole nation, the spiritual motive power of the Church ought to be separate from the secular motive power of the State; but all the 
more when Western Christendom has declined in each nation into an aggregate of conflicting sects.

I seem still to hear the din of this angry polemic, "Voluntaries" at war with the Church Establishment, which sounded during my undergraduate years in Glasgow and in Edinburgh. My first experience of a public meeting was of one to support the Establishment. I was repelled rather than attracted by it. I remember how one reverend orator asked the audience to witness that his opponents were not rightly called "voluntaries"; for instead they were the "vermin" of society, noxious parasites at work for its destruction. Perhaps a claim for national religious establishment was never urged in a more high-handed temper than by its leading advocates in the Church of Scotland at that time. Most of them, among others this speaker, were themselves cast upon the goodwill of the faithful a few years later.

It was in his own philanthropic spirit, but with characteristic one-sided intensity, that ecclesiastical Establishment and its expansion was argued for by Chalmers. The high - water mark was reached in lectures which he gave in London in 1838 , of which we got the substance in the Edinburgh class-room. It is curious to recall his 
position in the light of later ideas. He pressed the duty of the Christian State to "select" one Christian sect out of the national multitude of sects, for its agent in securing that Christianity should be presented to all within the nation, under a parochial arrangement which national legislation alone could command. But how could this be accomplished by a nation divided ecclesiastically into sects? Chalmers saw no difficulty either in England or Scotland. Free trade, or the economical law of supply and demand, applicable to human demand for bodily food, for which the appetite is always active, could not apply to religion, for which human demand is feeble and irregular. Protection, propulsion, by the steady support of the Christian State, and this not in the special interest of the protected sect, but for the sake of the community at large, was the inevitable alternative. For religion, as the highest of human necessities, must not be impeded by any multiplication of sects, or by imagined difficulty in selecting one of them as the religious organ of the State. The State must begin, Chalmers curiously assumed, by summarily excluding the one ecclesiastical organisation which has the allegiance of nearly half of Christendom. The 
question as between "Protestantism and Popery" was one about which, it seemed to him, only "an incompetent and vulgarised Parliament could have any doubt." For him the question was, whether infallible Scripture or fallible men should direct faith and conscience. As between the innumerable sectarian varieties of Protestantism Chalmers saw little room for difficulty. A selection ought to be made because of "the territorial principle." The parochial economy could not be sufficiently secured through the collective action of Protestant sects, each locally overlapping the other. Therefore all ought to agree, on the ground of common patriotism, to permit the territorial establishment of one among the many; with ample toleration for all the others outside. In selecting, the nation would naturally prefer the Church already in possession-Episcopal in England and Presbyterian in Scotland. 'To adrocates of religious equality, who ask why, when the reasons for difference among the Protestant sects are insignificant, they should, nevertheless, be treated thus, the reply of Chalmers was, "Why, when the differences are insignificant, do the sectaries keep aloof, for instance, from the Church of England, on considerations which are insignificant and paltry; caprices or 
whimsical peculiarities in which, through the very wantonness of freedom in this land of toleration, men have chosen to besport themselves? Substantially they are all right; and the State is justified in keeping to the sect already in possession, for the sake of the territorial principle, with its mighty benefits, which can only thus be enjoyed by all."

It was difficult to reconcile this philanthropic ideal of Chalmers with all that is implied in an equal national treatment of the aggregate of religions of which a nation is composed. On the other hand, agnostic religious indifference in all national functions, in a nation which had been converted for ages to a profession of Christianity, seemed a retrograde movement-an ebbtide of religion as the supreme social force-which must arrest national action in promoting the education of the community in any form, if religion is to be recognised as at all an agent in the education of mankind. Indeed mere financial endowment seemed not the most objectionable of the ways in which religion had received, or might receive, national countenance. The dogma of religious equality seemed to forbid national acknowledgment of a divided Christendom in any 
conceivable way. The Coronation Oath, or undenominational religion, as in the Irish national schools of those days, seemed not less, perhaps more, a contradiction to religious equality than a mere endowment given to one of many seets. I was apt to think that the advocates of religious equality had not touched the bottom of a deep question. The State could neither act in religion, nor refrain from acting, without conflicting with a Conformist or a Noneonformist eonseience. The dilemma seemed inextricable. I remember how in our College Debating Society the noneonformist members objected to opening its meetings with prayer, as ineonsistent with the duty of religious neutrality in a national university.

Thus assailed by Noneonformists, the Seottish Establishment, led by Chalmers, sought to popularise itself; and this, in evidence of its ecelesiastical autonomy, through its own independent agency, and without concert with the Legislature. In the generation which passed the Reform Bill appointment of ministers to parishes by unconditional patronage was to many a distasteful anachronism. It seemed also inconsistent with the ecelesiastical duty of guarding the faithful against the "intrusion" of ministers into particular 
parishes, contrary to the "will" of the people, and was, so it was argued, contrary to Scripture. Chalmers claimed for the Church power to forbid the scandal, and this solely in the exercise of its own divinely given autonomy. An ecclesiastical Act had in 1834 embodied this rule of Non-Intrusion. The civil courts, as normal interpreters of the conditions of Establishment, pronounced this ecclesiastical Act illegal. Thereupon the Church was divided about its duty, as between compromise and collision-divided, in short, between two opposite ideals of religious duty.

Tangled negotiations with statesmen when Lord Melbourne was Premier, and then under Sir Robert Peel, an ambiguous bill by Lord Aberdeen, tentative legislation by the House of Argyll, controversial pamphlets without number, the Scottish people in an ecclesiastical fever, sustained by clerical orators and actions in courts of law, all inflamed by the 'Witness' newspaper, the organ of the movement party, are among the memories of those troubled years, at the outlook in the Lorne manse. At first I contemplated the struggle with a sort of dramatic interest; later on with an interest more personal and ethical. 
"In this world," as Bacon says, "God and angels only may be spectators"; at any rate, one who is involved by his surroundings in the actions of a divided society cannot always retain a position of speculative neutrality and criticism.

Among the parliamentary utterances I remember a curious interest I somehow felt in those of Lord Melbourne: his philosophic laissez faire I believe concealed not a little recondite knowledge of theological debates. The fever-heat of the presbyterian ministers now and then ruffled even his placid temper; and on one occasion he expressed a hope, in prospect of an interview with a deputation of negotiators, that "that damned fellow Chalmers was not among them." And when Lord Aberdeen was disappointed by the inflexible tenacity of the ministers, Melbourne was surprised that one who knew Scotland so well as the noble earl, seemed not to know that in ecclesiastical arrogance the Presbyterian ministers were any lay more than a match for the Church of Rome. He was a bête noire of the ministers. One of them told me with horror that in 1831, when the Edinburgh Church History professorship was vacant, and Melbourne, as Home Secretary, had the appointment, his patience tried by friends 
of candidates, - "Hang it," he said to the last clerical interviewer, "let us give it to the Devil. He must know something about Church history." In the end it was given to Welsh.

In the mass of ephemeral tracts produced by this conflict, a few are of more permanent interest. Hugh Miller's 'Letter to Lord Brougham' is memorable for vigorous thought by a homely self-educated Scot, endowed with a mastery of English style seldom reached by his countrymen. And a few days before the Disruption, the ecclesiastical world was surprised by an announcement that Sir William Hamilton was about to address a letter of remonstrance to the recalcitrant ministers, who were preparing to withdraw from the Establishment. Few in Scotland wcre aware of Hamilton's eager interest in problems theological and ecclesiastical, or of his rare learning in this department, which had gained for him a doctorate in theology from the University of Leyden. A leading Scottish ecclesiastic seemed to resent as intrusion the interference of a philosophical layman, notwithstanding his theological doctorate. Indeed it is curious that with us custom confines this academical distinction to those ecclesiastically ordained; as if theological science was the ex- 
clusive perquisite of the clergy, instead of being a truly human pursuit, not less suited for indiscriminate academical encouragement than natural science, or jurisprudence, or philosophy.

Hamilton's "Letter," as he explains, was addressed only to "those not neologically disposed." He had nothing to say to ecclesiastics who regarded the Non-Intrusion legislation of the Church as an innovating reform in its constitution, enacted by the spiritual power without concert with its ally: the righteous course for all such was, he insisted, secession from the Establishment. But for those who desired "to walk in the old paths," he set himself to show that through ignorance they had unconsciously forsaken it, and were about to become "schismatics and martyrs by mistake." In fifty-nine pages of expostulation he offered what professed to be "A demonstration that the principle of Non-Intrusion, so far from being fundamental in the Church of Scotland, is subversive of the principles of that and every other Presbyterian Establishment." The "demonstration" turns mainly upon an alleged ambiguity in the term "will," which, "aceording to a distinetion fundamental in philosophy," is contrasted, instead of being identical, with sentiment and 
desire or aversion. A "unilateral" ecclesiastical rule had made the sentimental aversion of a majority in a congregation a bar to the settlement of a minister who had been nominated by a patron; and this Sir William tried to prove, by a large induction of instances, was in contradiction to the authority of every Presbyterian communion in Europe. The "Non-Intrusion Act" of the Church of Scotland was in short based upon a mistaken assumption, and so its continued maintenance implied rebellion against statutory obligation.

Hamilton's argument seemed scarcely to touch the high position of those to whom it was addressed. Chalmers claimed for the Church of Scotland the full liberty of a voluntary nonconformist society in its discipline, and (by implication) in evolving its theological doctrine, in the light of progressive knowledge;-always, of course, with the risk of the privileges of Establishment being withdrawn by the State; or by spontaneous separation, in whole or in part, of the Church, if its autonomous ecclesiastical action seemed to the Legislature to involve a sufficiently important "neological" departure from its original constitution. "I feel it an injustice to the sacred 
cause of the Headship of Christ," Chalmers said, " to be condescending to deal with the State on the specific question of Non-Intrusion. I would never even ask from the Legislature a recognition of Non-Intrusion. A far greater thing is at stake, even the right of giving effect to this and every other principle of a purely spiritual nature which seemeth to $u s$ a sound one." With national support always contingent, the "selected sect," in short, claimed freedom to modify its discipline and transform its doctrine according to its own free will.

It is strange, even pathetic, now to revive in memory those echoes of stormy controversy in a past generation.

I had now finished the necessary theological studies in the university. Neutrality and criticism were no longer open, with disruption imminent, if I was to make the experiment of an ecclesiastical career. The choice lay between the ideal of the remanent majority, with its modified ecclesiastical autonomy, and the ideal of the minority, about to separate from the Establishment because its unconditional liberty had been disallowed by the British Legislature. Present work for the gool 
of others, instead of continued solitary encounter with "obstinate questionings," might help, one hoped, to practical answers; and although neither of the rival paths was wholly acceptable, perhaps the more obvious self-sacrifice involved, commended one of them to some inherited share of Puritan temper. I remembered too the maxim of Descartes, which enjoined acceptance of one's spiritual inheritance, until some good reason for rejecting or modifying it should appear. The "crede, ut intelligas" of St Augustine was here to be preferred to the "intellige, ut credas" of the rival maxim. Then, as between the disrupt portions of the Church of Scotland, progressive theological science and philanthropic enterprise seemed to juvenile enthusiasm to find their most hopeful home in a religious organism that was self-contained, and independent of the contingencies of national support. Family feeling, too (for the manse family were among the separatists), the personal magnetism of Chalmers, and sympathy with those who made apparently the larger sacrifice, were all, I think, auxiliary motives.

I was at the manse in Lorne during May 1843, contemplating the Disruption at a distance. I 
had a few weeks before been admitted to the ministry. Later in that summer I accepted the invitation of the authorities to work in the beautiful parish of Cramond in Mid-Lothian. My early home at Ardchattan was after this unvisited for more than thirty years, during which I was a stranger, returning to it after this long interval surrounded by another generation, as our family retreat in two successive summers of academical holiday in 1876 and 1877.

Beneath the surface of this Scottish Disruption, obscured by provincial technicalities, argued with scholastic subtlety and fanatical ferrour, one found perplexing questions which underlic political action in all countries, in a Christendom rent by sectarian dirisions, and with its deepened interpretation of the duty of religious toleration. It was the issue of an experiment which tested Chalmers's theory of selection by the State of one out of the aggregate of Protestant sects, as the organ of the nation for its own religious education; the selected sect continuing absolutely self-governing in discipline and doctrine. The excluded rival sects resented the confinement of national countenance to one; and the nation, through its Legislature, claimed a right to re- 
strain the discipline and doctrine of the chosen sect within alleged statutory conditions of support. The remanent Establishment was satisfied with a more modified freedom, in return for the advantage to religion of national support, and in order to arrest the modern tendency to agnostic secularisation of the State.

Thus in England and in Scotland the ideal of the Church as a visible organised society was revived in the nineteenth century, but in each under a different conception. For the Anglican movement the note of the Church was visible in its hierarchical continuity, embracing Catholicism -Roman, Greek, and Anglican-and excluding the protesting sects. Under the Scottish ideal, in its extreme form, unconditional autonomy-absolutely independent of Popes, Kings, or Parliaments - was an essential note of ecclesiastical organisation; logically excluding the Roman communion, and the Greek and Protestant religious establishments of Europe. The Anglican criterion would thus unchurch nearly one-fourth of Christendom; the Scottish test would unchurch threefourths, finding its organised visible Church in the unestablished sects of Europe and America.

In my new home in Mid-Lothian I desired to 
resume farourite studies in union with philanthropic work, not in collision but in friendly relations with the remanent Establishment, which, not without painful sacrifice, had followed its own ideal of Christian duty.

As it happened, I had about this time been pleased by the picture of Arthur Collier, the rector of Steeple Langford in Wiltshire early in the eighteenth century, as he appears in his life by Benson. Collier's 'Clavis Universalis, or Demonstration of the Non-Existence of an External World,' somehow touched my imagination by the romance of its origin and fortunes, while it exercised my understanding by its metaphysical acuteness. Collier was a self-reliant Anglican thinker, an Arian of the school of Clarke, and an Apollinarian, "a ligh churchman on grounds which high ehurchmen could not understand," withal a religiously devoted parish priest. Perhaps the self-contained life of religious thought could be realised in a rural parish in Seotland as well as in Wiltshire. At least I liked to think of him in his intellectual and philanthropic work in the rural English parish which I hoped some day to visit. That hope was fulfilled in the summer of 1903, after the lapse of sixty 
years, when I was taken by Mr and Mrs Edward Tennant to see the church in which Collier officiated, and the rectory with its garden in which he mused, all fitted for meditative purposes, in its beautiful valley, seven miles from the rectory of Bemerton, in Collier's day occupied by John Norris, "the English Malebranche," and not far from the Wiltshire home of Richard Hooker.

I soon found that an Arthur Collier-like life, in a rural parish in Scotland, in the heat of a Scottish ecclesiastical war, was an illusion of one inexperienced in life. The convulsion, with its obscure consequences in the far-off future, touched men too deeply. Even social intercourse was repulsive to both parties. Enthusiasm exults in martyrdom, but to practise charity is less easy. The intense polemical temper dissolved former dreams of the unity of Christendom; and one found that individual liberty might be in inverse ratio to the freedom of the social organism in which the individual is included. Yet there is now romance and pathos in the memories of that troubled year, and the ' 43 opened a new era in the ecclesiastical life of Scotland, as the ' 45 in the previous century did in its social civilisation. 
One has to be one's self in order to be or do anything, whatever the character of the self may be, and my bent was too strong to be turned aside. War about non-intrusion under the shadow of an unsettled final problem seemed like Nero diverting himself when Rome was burning. In the spring of 1845 Berkeley was again in my hand, and with the 'Leibniz,' Hamiltou's gift years before, revived grave interest in the ultimate meaning of life in the strange universe, and this with a practical regard much more than as a speculative adventure.

While thus disposed, an unexpected letter received one morning encouraged this philosophical revival, and became a turning-point in my life. It was a request by the editor of the "North British Review' for an article "on some philosophical subject." The 'North British' was a lately founded literary and scientific quarterly, in design more hospitable to religious interests than the 'Edinburgh' was supposed to be, but professedly independent of sectarian influence. It began its course in the year before, with the countenance largely of Free Churchmen of liberal tendencies. Welsh, the Church historian, was editor in its first year; but the letter was from Edward Maitland, 
afterwards Lord Barcaple, who had succeeded Welsh. Sir David Brewster was a constant contributor for science, and Chalmers for theology and social economy. It appeared that Hamilton had spoken indulgently to Welsh and others of my philosophical inclination, which explained the unexpected proposal. I had been attracted to the 'Review' as a reader, but I had not appeared even in the humblest form in print, nor conceived the possibility of already sharing in this enterprise. At last I ventured to suggest "Berkeley" or "Leibniz," as alternative subjects for an article. Mr Maitland preferred "Leibniz," with prominence given to his personality instead of to abstract philosophy. The eclecticism of the German, his curious learning, not unlike Hamilton's, the optimist conception of the universe in the 'Theodicée,' and his negotiations for a comprehensive union of divided Christendom, were full of interest, and my juvcnile essay, inadequate as it now appears, was received with unmerited consideration. It opened the way to wider social intercourse and other consequences.

Already the months at Cramond had been enlivened by occasional intercourse with Patrick MacDougall, years before a notable in the class- 
room of Chalmers, now a master in the Edinburgh Academy. He had already produced, in the 'Presbyterian Review,' criticisms of Jonathan Edwards and of Samuel Clarke, in an involved style of sombre rhetoric, but with a moral fervour and intellectual promise which justified his appearance in 1836 as a competitor with Hamilton and Isaac Taylor for the Chair of Logic. His powerful personality and Johnsonian tabletalk, sustained by a magnanimous spirit, now added attraction to Edinburgh life. The sensitive organism that is often associated with genius in the end impaired his power. His juvenile essays on freewill and theism, and the memories of students and friends, are the remaining justifieation of the enthusiastic admiration of Chalmers. In later years he was one of my academical colleagues, as Professor of Moral Philosophy.

Granton House, in the neighbourhood, was occupied by Graham Spiers, Sheriff of MidLothian, one of the best and wisest among the leaders of the Free Church, whose hospitality and advice were always open to me when I was at Cramond. There I met persons of note, mostly Free Church clergymen and laymen: Welsh, my old professor, in the last year of his 
life; Candlish, the brilliant and versatile ecclesiastic, next in succession to Chalmers; and the philanthropic Guthrie, along with Chalmers and Caird, one of three illustrious Scottish preachers in the nineteenth century. Among the laymen Sir David Brewster was foremost. He was then Principal at St Andrews, threatened with expulsion from his office as a Free Church seceder-the Church Establishment claiming exclusive possession of the university chairs. Sir Darid was my constant friend in the remaining quarter of a century of his long life. A scientific discoverer and a brilliant expositor of science, whose charm of conversation, single-handed or in the social circle, was curiously arrested when it came to public speech. He exchanged the Principalship at St Andrews for that in Edinburgh in 1859, when he came to us with a reputation for pugnacity belied by nine years of benignant rule. It was, I think, in the course of these two year's at Cramond that I first met Hugh Niller, the creator of the 'Witness' newspaper, in which the severity of sectarian controversy was happily relieved by essays written in the English of Goldsmith. Some of them afterwards formed his 'Schools and Schoolmasters' and his 'First Im- 
pressions of England,' a book delightful in the freshness of its survey of scenes apt to lose their charm by familiarity, charged for him with the imaginative sentiment of a stranger who was familiar with Shakespeare, and Shenstone, and Cowper. The gentle voice and modest demeanour of this remarkable man surprised one who had associated him with the polemical invective of the 'Witness'; and his endless conversational store, gathered by original observation, individually directed reading, and sometimes whimsical inference, made his talk always interesting.

One of my last days at Cramond, partly spent with Lord Jeffrey in his home at Craigcrook. supplies a pleasant reminiscence of a celebrated Scot, whose temper of benignity and sweet reasonableness and warmth of kindness in his old age, was unlike what one looked for in the supercilious editor of the 'Edinburgh Review.'

Not long after the appearance of the "Leibniz" in the 'North British,' an announcement was made which was even more surprising than $\mathrm{Mr}$ Maitland's letter. A professorship of logic in the New College of the Free Church was pro- 
posed to me. It had been offered, I was told, to Isaac Taylor, and when he declined to Henry Rogers, still without acceptance; and then, on the motion of Brewster, the electors turned thus graciously to an untried student of philosophy, whose youthful questionings, it was hoped, might in this capacity awaken thought in other students.

Not without misgiving, in the end I gratefully closed with an offer which might relieve an embarrassment. It suited the state of mind, inquisitive rather than dogmatic, in which I still found myself; and the rigid enforcement of the test which bound the Chairs of Philosophy in the national universities to the Church of Scotland was a bar otherwise to a professorial career. The idea of a liberated university for Scotland had been already suggested by John Stuart Blackic. "With this threatened enforcement of tests," - so he argued, - "I do not see anything to hinder Free Churchmen from erecting a separate literary and scientific College, as they have already done a theological one. I do not wish to see such an issue. Nevertheless, if these proceedings are followed up by the bigoted presbyteries who shall be declared to 
have power over the old universities, then I hesitate not to give this advice to Free Churehmen and all Dissenters:-If these men drive Free Church professors out, take your students along with them, and build a great College for yourselves. You will thus perform an essential service to Scotland, and reap no small glory to yourselves, by ereeting a Free University in this country, founded on the broad and deep principle of humanity and fraternity; a university with religion and with Christianity, but without monopoly and without tests." It was some thought like this that I had in my mind when in 1846 I resumed a philosophical career.

That summer was partly spent in England and in France, for recovery of health and spirit, and in preparation for the future. Paris was interesting for Pascal and Malebranche among the dead, and for Cousin and Rémusat among the living. In England I saw Bedford and Elstow, places associated with Bunyan; Olney and the haunts of Cowper; and Rugby, with its memories of Arnold. 


\section{CHAPTER IV.}

RETURN TO PHILOSOPHY : 'NORTH BRITISH REVIEW.'

$$
1846-1856
$$

"I confess that in philosophy I am a seeker."

-Joseph Glanvile.

Thus unexpectedly I seemed to have escaped from ecclesiastical strife into the tranquil if obscure region of philosophy. In making this transition I was inspired by the idea of a "great free university, founded on the broad and deep principles of humanity in union with Christianity," and I returned with enthusiasm to questions which had been an absorbing interest in earlier years.

In the first winter I was surrounded by ninety students. I tried to provide them with aids to reflection-chiefly by discussing questions proposed by Descartes and Locke and the Scottish philosophers, especially Hume, Reid, and Hamilton. The colleagues by whom I was especi- 
ally incited were Chalmers, who was Principal, still teaching theology, whose gracious words introduced me to the students; John Duncan, eccentric Hebraist and mystical thinker, a good man in pursuit of truth, "Pascal in Scotland," whose pregnant fragments of thought have been fitly preserved by Professor Knight in 'Colloquia Peripatetica'; and, not least among them, Patrick Macdougall, who had invigorated me at Cramond, and was now unfolding ethical philosophy in lectures charged with Celtic fire.

Among the students I was particularly attracted to three. One was John Veitch, afterwards well known as Professor of Logic at St Andrews and at Glasgow, and as a destructive critic alike of transcendental and descendental philosophies, who realised life in the spirit of Wordsworth, my firm friend till death withdrew him half a century later. I found this youth already touched by the secnery and traditions of his native Borderland, which inspired the best work of his later life. Another was Alexander Balmain Bruce, already an intrepid thinker, in the last quarter of the century a theological professor in the College of the Free Church at Glasgow, a notable leader in the listorical criti- 
cism and liberal religious thought, for which his Church has been distinguished in this generation. The creed of Christendom at a future date, more or less remote, was thus summed up in anticipation by Bruce in later life: "Faith in one Supreme Will, good and for ever working for good, at the heart of the universe; man's chief end to serve this Will in filial freedom; life on earth on these terms worth living; life beyond the tomb an object of rational hope, if not of undoubting certainty." This formula of faith is suggested in the closing chapter of his Gifford lectures in 1899. The third in the academical trio was Alexander Nicolson, a Celtic genius, awakened and spiritually nourished by the scenes and historic legends of his native Isle of Skye, full of promise, but whose promise in early life was disappointed by an easy disposition and desultory habits that paralysed his undoubted power of imagination.

A considerable event in the history of philosophy in Scotland occurred in 1846. This was the publication of Hamilton's annotated edition of the works of Thomas Reid, the representative of a method of dealing with ultimate questions 
that is distinctively Scottish. The homely text of Reid was enriched by his editor with an extraordinary accumulation of Greek and medicval as well as German erudition, which, along with Hamilton's own comments, raised questions till then unconceived in the limited psychology of Scotland. In expanding its scope, and thus tending, more or less consciously, to transform inductive science of mind in man into ultimate philosophy of the universe, Hamilton, as I have said, found allies not only in Coleridge and Thomas Carlyle, but in the eminent philosophers who were making Kant and Hegel familiar to students in the Sorbonne. Victor Cousin, their leader, had been adversely criticised by Hamilton in 1829. In the interval Cousin's eclectic temper had more than conciliated his critic, who became one of his warmest eulogists. Through Cousin the thoughts of Kant and Fichte and Schelling were conveyed to Edinburgh students with less intellectual strain than in the severe technical dialect of Hamilton - under a sunny haze, in the expositions of the eloquent Frenchman. Through these channels the new wine of Germany was beginning to find its way into the old bottles of Scottish philosophy. 
To Chalmers, philosophically educated almost exclusively in the school of Reid and Brown, the Germans, and even the Frenchmen, were for him names portending a revolution that somehow menaced the foundations of Christian faith. In 1846, for the first time, he believed he had found a way to face the dreaded evil. Morell's 'History of European Philosophy in the Nineteenth Century' made its appearance, and in luminous English did for English readers partly what Cousin had done for French. In the summer of 1846 Chalmers revelled in the book, and began with juvenile enthusiam, almost in his serentieth year, to study Kant and Hegel through Morell. Thus faced, the dreaded spectre seemed to dissolve before his eyes. Instead of formidable heresies he could see in the German systems only empty abstractions for which high-sounding words did duty. He resolved to make his discovery known in a short course of public lectures, in the winter of 1846. The substance of them was reproduced as a sort of manifesto in the 'North British Review.' The Morell incident is biographically interesting as characteristic reaction of impetuous genius against forces which have since issued in a revolution of our insular philo- 
sophical and religious thought. It was the first half of the nineteenth century in Scotland in a preparatory encounter with the second.

It was impossible to accept this fervid and personally interesting protest as a sufficient critical estimate of the far-reaching conceptions to which Chalmers had been so lately introduced, and now encountered with a beautiful simplicity and enthusiasm. The article in the 'North British' was his last work in authorship: it appeared only a few weeks before his death. "Had there been no perverse metaphysics to bewilder men, there would have been no need for metaphysicians," was its watchword: like the spear of Achilles, the only service of metaphysics was to heal the wounds itself had made. "The child sees an apple on the table, and affirms a real apple to be there. A Berkeleyan philosopher labours to disprove the assertion. A second metaphysician arises and repels the sophistry of the first. But it is not this second metaphysician who gives the law to the child; he but recognises and respects the law already planted in his mental constitution by the hand of nature." Chalmers, in all this, takes for granted that the "Berkeleyan" philosopher, instead of merely in- 
terpreting anew the common-sense that obliges us all to find reality in the data of sense, means to rebel against common-sense, and insanely to deny that the material world has any sort of real existence. Inductive science of mental phenomena in man was the highest conception of metaphysics with Chalmers; not the divine rationale of the universe, which Berkeley alone among British metaphysicians approached, and which German philosophers were labouring to articulate.

This disparagement of metaphysics, in the form of an assault upon what Chalmers called the "nihilism" of Hegel, was rather a discouragement in his first professorial winter to an inexperienced youth, called to awaken metaphysical reflection in other young men. The mental tension of this winter was followed next year by reaction, and it was not till 1848 that I felt at home. I passed some months of that summer in England, with social opportunities less limited than those imposed by existing ecclesiastical restraint in Scotland. I saw Cambridge for the first time, with introductions to Carus and Sedgwick, also from Brewster to Mr Thomson, now Lord Kelvin, and to Stokes, soon after in the chair of Newton, and lately Gifford lecturer on natural theology in Edin- 
burgh. Cambridge interested me by its associations with Bacon and Newton, Cudworth and his allies, and in later years Paley and Simeon. Some weeks at Bath seemed to carry one into the eighteenth century. Coleridge, Wordsworth, and Arnold made me feel already among familiar scenes, in a first visit this year to Westmoreland, which became a summer home in later life.

Hamilton's "Reid" supplied me with a text for an essay in the 'North British.' It was the first of a series of essays suggested by Hamiltonian philosophy. It dealt with Hamilton's account of our direct intercourse, through sense, with reality in the form of matter; this used in refutation of fundamental scepticism. It was an opportunity for illustrating Hamilton's enlargement of Reid's argument against the dogma "that nothing can be perceived but what is within the mind which perceives it," which Reid had assailed as the root of philosophic doubt.

Perception of what is outside the individual percipient is, moreover, correlative to faith in the free agency in which our individual personality is revealed to us. I was thus led to consider Hamilton's way of dealing with the suspected contradiction between free agency and 
natural necessity in the economy of the universe. In regard to this last he wrote to me thus :"If I were to specify any part of your article, it would be your notice of my doctrine, undeveloped as it is, touching the counter schemes of Liberty and Necessity. I am convinced that nothing would more contribute to the furtherance of theological charity than the application of the principle of the Conditioned to this question. If correct, it is an Irenicon of a bitter and undecided controversy, which has always divided theologians and philosophers. It is a doctrine of humility, and also the true biblical doctrine."

Intercourse with Sir William Hamilton in these years was strength and encouragement in my isolation. His library at Great King Street, its shelves richly laden with medieval and foreign books of philosophy and theology, and the social reunions of which it was the scene, are abiding memories of happy hours. Among others whom I then met there was Doctor Logan, a learned priest of the Roman communion, then living in Edinburgh with his pupils, the late Lord Acton, and another, I think afterwards Cardinal Howard. The society of philosophical Catholics is attractive, as it commonly 
unites reverential temper with acute speculative treatment of the awful questions which underlie human life. Dr Hanna, too, then the accomplished head of the Edinburgh Academy, afterwards Archdeacon of Chichester, was often of the party at Sir William's.

In the meantime Comte was gradually superseding Cousin in France, although the 'Philosophie Positive' was treated by Hamilton as unworthy even of contemptuous allusion. When I once mentioned Comte he said he did not know any claim he had to be named among philosophers. An intellectual agent in Britain, akin to Comte, was also at work, for whom Hamilton professed equal indifference. After 1843 J. S. Mill's 'System of Logic' gradually came to play a leading part in the spiritual history of that and the two following decades. Mill's idea of causation and power resembled Brown's and still more Hume's, also Berkeley's on its negative side. And Mill connected logic with pressing social questions, in a way that was acceptable to Anglo-Saxon taste. He dealt chiefly with a part of logic which Hamilton neglected. In Hamiltonian logic the rationale of probable evidence was subordinate. He was 
chiefly concerned with elaborate articulation of abstract logical forms, in obedience to his favourite principle of express and unrestrained quantification of the predicate in propositions, a principle which he claimed to have discovered.

It was in this state of the philosophical atmosphere in Scotland that I was engaged in philosophical work in the 'Forties. I could now reflect at leisure upon the articles of the Hamiltonian creed, comparing them with those of J. S. Mill. Our perception of reality in sense; interpretation of perceived phenomena in the physical sciences; the ultimate foundation of human interpretation of natural phenomena; and the sphere within which our interpretation is inexorably confined, - all this, intrepidly pursued, led at last to the perennial antithesis between empiricism and idealism as ways of thinking about the universe we live in. My old questions about the trustuorthiness of any interpretations of the appearances with which we come into contact in sense again became urgent. This led to more careful study of the 'Novum Organum' and the 'De Augmentis,' and to comparison of both with the 'Organon' of 
Aristotle. The main question of his 'Essay' made Locke a favourite companion, supplemented and corrected by Kant. My inclination was to an English manner of treatment, so far as it keeps firm hold of what is given in concrete experience, under conditions of place and time, and refuses to pursue a unity that is possible for men only in a world of abstractions. I seemed to find that in philosophy things must at last be "left abrupt," as Bacon puts it.

A difficulty much felt by me about this time was how to reconcile the universality implicd in science with the particularity which belongs to its empirical data. I wanted to sce what rational assurance there was for the trustworthiness of inductions from experience. What security have we in arguing from the past to an unknown future, or what reason for indulging in expectation of any sort? I seemed to be face to face with a dilemma between total scepticism and total credulity. Without postulates one cannot move at all intellectually; yet may not the postulates be only illusions of individual imagination? So I was perplexed between the profound need for final faith on the one hand, and the difficulty of vindicating final faith on 
the other. Crede, ut intelligas seemed to contradict instead of being the necessary counterpart to Intellige, ut credas. It was later on that I found more light on these searching questions.

In the winter of 1849-50 an incident occurred which helped to determine my career. I was asked by the proprietors of the 'North British Review' to undertake the editorship of that journal, which Doctor Hanna, a liberal and accomplished Free Churchman, the son-in-law of Chalmers, had conducted successfully for two years. The proposal was adapted to my circumstances. The College had been deprived by death of the magnanimous enthusiasm of Chalmers, and the cosmopolitan conception of a "Free University" was disappearing, in the interest of a Theological College, now out of sympathy with the philosophical temper. Under these conditions the office which I held was out of place; and with the prospect of the removal of tests in the national universities, its raison d'etre might soon be taken away. In the meantime the 'Review,' with its benignant purpose, might afford a counteractive influence. So I accepted the offer, 
and for the next seven years tried to pursue an editorial ideal along with academical work.

The condition of Scotland at that time was unfavourable to a dispassionate treatment of ecclesiastical and theological opinions, in the way with which we are familiar, for instance in the "Nineteenth Century' and the 'Contemporary,' or in the 'Hibbert Journal.' But it was in this spirit that I wanted to guide the 'North British.' So I had to look for articles concerned with religion and ecclesiastical sects, not exclusively to Scottish ecclesiastics, with most of whom criticism and interpretation of Scripture were dogmatically taken as stereotyped for all time in the sixteenth century. Then for national politics, Edinburgh was less in touch with public affairs than when the centripetal action of London upon the provinces was less powerful.

Moved by these ideas, I spent part of the summer of 1850 in England, happily uniting with my marriage tour literary negotiation on behalf of the 'North British Review.'

In London I found a sympathetic friend in Frederick Denison Maurice. He was inspired by 
a noble philanthropy, and was then intent upon his experiments in Christian Socialism. Chalmers was gone, and I found in him a larger humanity than in the abstract theology and ecclesiastical polemic of Scotland. $\mathrm{He}$ introduced me to Charles Kingsley and Arthur Stanley, and to J. W. Ludlow, who all afterwards co-operated. Kingsley and Ludlow were steady contributors. Bunsen, the Prussian ambassador, was a cordial friend.

Two figures are prominent in the London memories of that year. My first meeting with Thomas Carlyle was at his house in Chelsea, where I spent an evening in company with David Masson, then settled in the metropolis. I seem to see, in a lurid firelit chamber, the weird-like figure of the sage, now and again replenishing the fire, while discharging merciless denunciation of the political and religious vices of his generation, and the unreality of its literatureall for the benefit of a young and inexperienced editor; the turgid monologue now and then relieved by occasional coruscations of Mrs Carlyle's ready wit.-On another day I saw J. S. Mill for the first time. He was in his room at the India Office in Leadenhall Street. Mill was at the oppo- 
site pole to Carlyle. He was calm and luminous in discourse; an easy flow of well-fitted words and compact sentences; reasoned opinions, all ready and freely expressed on many interesting subjects incidentally suggested; sweetness of temper and philosophic modesty; a disposition to see good in religious and philosophical ideas different from his own,-all attracted one to this typical representative in the middle of the nineteenth century of English method in philosophy.

A fortnight at Oxford in that summer made no abatement in the Oxford enthusiasm of 1842 . Days at Pembroke College with the Jeunes, the hospitalities of Stanley and Conington at University College, and of Thompson, afterwards Archbishop of York, at Queen's, where Edward Freeman was also met, Mansel at St John's and Sewell at Exeter, as well as breakfasts with Church, Burgon, Marriott, Poste, Earle, and Chase at Oriel, on bright mornings in June, are among the unfading pictures of Oxford in those days. Oxford was still medieval Oxford; the quaint old college life was undisturbed by the changes which began in 1854, then only heralded by the voice of reformers like Jeune and Stanley. But the omnipresent Newmanism of 1842 had disip- 
peared, superseded for many by J. S. Mill and the 'Philosophie Positive.'

Another experience in that summer was at Herstmonceaux Rectory in Sussex, the beautiful home of Archdeacon Hare, where we passed days of much enjoyment, amongst literary treasures and works of art, while the ardent conversation of our host opened surprising vistas of thought and literary enterprise. It was a charming rural parsonage in the woodlands of Sussex; an uncommon homelife within; outside was expanse of English landscape, the ruined Castle of Herstmonceaux, with Pevensey Level in the foreground, and the English Channel in the distance. Well remembered by two persons still living are "the late breakfast in the sunny book-built room, with the scent of the orange-trees and geraniums wafted through open doors of the conservatory, the vehement declamation over the newspaper, the frequent interpolations of a reading from Wordsworth, or Coleridge, or Goethe." Five years later this ideal family life was dissolved by death.

I returned to Scotland desiring to inspire the 'North British Review' with some of this spirit. Other coadjutors gathered round as 
time went on. Bonamy Price, the favourite colleague of Arnold at Rugby, was spending the winter of 1850 in Edinburgh, my warm friend in the forty years that followed till his death. His ardent spirit helped me in many ways. Through Price I secured the political insight of W. R. Greg, after visiting him at his villa on Windermere,-a host in himself and a constant contributor on domestic and French politics, in the years of coalition Cabinets (when he earned the name of the "Cabinet-maker"), Napoleonic rule, and Crimean war. Archbishop Whately was another intimacy due to Price, fruitful in characteristic letters and otherwise helpful by articles. The genial hospitality of Nassau Senior in his house at South Kensington, and the social interest of his contributions to the 'Review,' must not be forgotten. Then there was Abraham Hayward, redolent of London life at Lady Palmerston's reunions and at breakfasts with Monckton Milnes; Madame Blaze de Bury, with her Parisian experience and ready pen; J. W. Kaye, versed alike in Indian politics and the morals and manners of English rural life; Whewell of Cambridge, an occasional contributor, long familiar as a philosophical analyst 
of science in rivalry to J. S. Mill, now as the ingenious author of 'The Plurality of Worlds'; Isaac Taylor, the admired author of the 'Natural History of Enthusiasm'; Herbert Spencer,' then emerging into public view, since a conspicuous figure in the philosophical world; greatly valued among them all David Masson, my early friend, now a potent literary ally. In Scotland the incomparable "Rab" was always a wise and warm supporter. I gained the help of John Tulloch, after a visit to his manse of Kettins in 1854, a few months before Lord Palmerston placed him in the Principal's chair at St Andrews; and the powerful literary influence of the Duke of Argyll. Each number had an article by Brewster.

My own writing in the 'Review' was confined to a few philosophical essays-outlets for thought that happened to be dominant at the time.

1 Herbert Spencer contributed a characteristic essay on "The Art of Education" in May 1854, which evoked remonstrance from some, as at variance with their canons of educational orthodoxy, but it seemed to express ideas likely to encourage thought. The same number of the 'Review' contains articles by Brewster', Greg, Masson, Tait (afterwards Archbishop of Canterbury), and Coventry Patmore. 
Hamilton's 'Philosophical Discussions' led me in 1852 to reconsider the meaning of Causation, and the origin of our mental determination to refund all changes into causes. This Hamilton explained as the consequence of finite intelligence holding necessarily inadequate intercourse with infinite Reality. This implies, he argued, our inability to eonceive change as added reality, or as more than a new phase of eternally identical Being. The determination to refund a change into its cause is thus virtually a refusal to regard it as something contributed to the already infinite aggregate of existence. This negative view of Causation secmed unduly to attenuate the conception, and to take no account of what is implied in active originating Power. So I ventured to dissent in favour of a conception of which I was not then fully master. I was begimning to think that the mental demand for the physical cause of an event is a consequence of the inability of the human mind to suppose that nature is firally unintelligible, and therefore uninterpretable. Are we not, as intelligent beings, I asked myself, somehow inspired by the faith that we are living and having our being in an ever-evolving cosmos, not in eternally changing chaos? And 
does not this mean that we are all having our being in Mind; that the Universe in which we participate through our experience is in its heart Universal Mind? The inexorable demand for a cause when we see change was thus ultimately our recognition of the immanence of Omnipotent Mind. How we have this faith, and also faith in the Goodness of the Universal Mind, I did not then fully see. But a connected question here arose.

Is this Omniscient Agent, this background of the Universe, intelligible to finite human mind? Is God knowable by man? Can Mind that is Universal have anything in common with, or analogous to, the mind we find in ourselves? This question, which seemed to grow out of the foregoing idea of the Active Reason with which the Universe is always charged, was expressly suggested by Calderwood's 'Philosophy of the Infinite,' in the following year. That Infinite Quantity, in the form of infinite space, infinite time, or infinite causal succession, must be inconceivable, under the conditions by which intelligence is limited in man, had been the last word of Hamilton; with its corollary, that God, because infinite, must be ultimately inconceivable; so that it is blasphemy 
to suppose that we can fully realise God in our thought. Calderwood's argument was apparently directed against this.

In an essay on "The Insoluble Problem," in the 'North British,' I pondered over this supreme part of Hamilton's philosophy. While the language in which it was expressed was paradoxical, I believed that it was in intention only an expansion of what is involved in the question in the Bible- "Who by searching can find out God, who can find out the Almighty unto perfection?" An exhaustive explanation of the mysteries in the Divine Reality seemed possible only in Omniscience; but man is not and eannot become omniscient. Yet this intellectual helplessness was not inconsistent with a progressive human knowledge of the Active Reason that is (so far) revealed in all the facts and laws of the physical and spiritual universe. Nor would Hamilton, I daresay, have denied this; although his point of view led him to lay an emphasis upon the ultimate incomprehensibility, not upon this practical revelation of the Universal Mind or Will. Thus God was in one sense revealable and actually revealed; yet in the highest sense concealed in a reality deeper 
than human knowledge ean go, yet enough known to sustain human hope and eharity.

I found, too, that "the unknowableness of God" was an old doctrine among thinking men, aggravated in discussion by the ambiguity of language. It underlay the philosophy of Plotinus and Scotus Erigena, and in the modern world it was debated between Bishop Berkeley and Bishop Browne. May we not regard the ever-changing universe as an embodiment of God; in analogy to the finite bodily organisms through which mind in our fellow-men is revealed to our senses? Or is this analogy forbidden by its human limitations, so that man is for ever excluded from knowledge of the ineffable Divine mystery? Is all this only a controversy about the meaning of the word "knowledge"? If real "knowledge" must exclude all mysteries, the term is inapplicable to an intelligence that in the end must become faith, or incomplete knowledge. On the other hand, if the term is confined in its application, as it is by those who recognise no other "knowledge" than physical, should we not, with the mystics, speak of our divine experience as ecstatic vision, or else as theistic faith? Questions like these were now rising in my thought. 
In a letter regarding this article Hamilton explained his meaning thus: "I cannot acquiesce in the statement that I hold an extreme view in regard to 'The Insoluble Problem.' I maintain that man is cognisant of God inasmuch, and in as far, as God is revealed to the limited human faculties; and I further anxiously maintain that Belief is the organ by which man specially and appropriately compasses what he is unable adequately to comprehend. I am anxious to see the work of Bishop Browne to which you refer. I have his 'Procedure and Limits of Human Understanding,' and also his 'Answer to Toland,' but not his 'Divine Analogy.'" Hamilton, I am convinced, would have been the last to say that total religious nescience or agnosticism, on the part of man, was the logical issue of the "unknowableness," or rather the incomprehensibility, of God.

If the universe of reality, given in physical and in spiritual experience,-experience non-Christian as well as Christian, - is our revelation of God, what are we to say about the contents of this revelation? What especially about the moral character of the universe thus unfolded? In 
this divine revelation of the Supreme Power evil is strangely intermingled with good. With a revelation like this of the Power that ultimately animates and regulates the universe, how dare we assert that that Power is omnipotent and omniscient Goodness impersonate? But if God is not perfectly good, there is practically no God at all. Mozley's book on 'Augustinian Predestination,' published in 1855, fell in with this train of thought. I made it the subject of a few pages in the 'Review.' It went to connect the suffering and moral evil presented in our experience of God with the two ultimate mysteries which Kant loved to ponder-the Starry Heaven and the Moral Law. The first departs from the spot where I stand on earth, expands beyond the bounds of imagination, worlds rising beyond worlds, and systems blending with systems, into illimitable Space. The other departs from my responsible personality in its invisible unity, in which Moral Law reveals a spiritual life that must be independent of animal nature, and of the whole material world, conceding no compromise to any external necessitation. This raises the question of the correlation of these two opposites - the faith that we are personally 
responsible for our evil acts, so far as they are our own, and so not due to Nature, or rather to God, by whom Nature is animated; and, in seeming contradiction to all this, our faith in the universality of physical order. In theological language we have here to show the possibility of independent will in persons being consistent with universal predestination in God. Are these opposites necessarily contradictories? Can man know enough of either to justify the assertion that they must be absolutely inconsistent? Does the moral judgment destroy the judgment of physical causality, or vice versa, when both are rightly interpreted? I wanted to show that each of these principles must at last retire into an incomprehensible mystery-the one into the mystery of an infinite causal regress, and the other into the mystery of unconditioned origination. They may be harmonious in Omniscience, as they are in human life. Therefore if there is otherwise evidence for each, we are bound to believe both; although their consistency cannot be fully articulated in a human understanding. So the suffering and sin contained in the universe may be finally due, not to Nature, which universally obeys God, but to man, by his independent im- 
moral agency, which introduces evil-at least for a time. Unless the existence of a moral agent is, so to speak, an unrighteous Divine experiment, evil may enter the universe, and still God be omnipotent and perfectly good. I have since followed this line of thought further.

Ferrier's 'Theory of Knowing and Being' made its appearance in the same year. In the 'Review' I tried to do justice to its artistic charm and subtle reasoning, as well as to its paradoxical conclusions and perverse criticism of "commonsense" philosophy. The proper function of the metaphysician, according to Ferrier, is to maintain a perennial war with the common-sense of mankind, which is only an original dowry of error. It was the office of the true philosopher to substitute for this misleading guide an awakened consciousness of the Absolute Reason that appears in the necessities of thought. Reason thus identified with real existence had a superficial resemblance to the Berkeleyan conception of Divine Reality. This disappeared after consideration. With Ferrier philosophy was logical development of abstract conclusions involved in abstract principles; the contingent world of change was 
irrelevant. Berkeley, on the other hand, in the spirit of Bacon and English philosophy, kept hold of the concrete and ever-changing universe, in its experienced relation to human life and to God. Ferrier moreover seemed illegitimately to identify the critically interpreted common-sense of the true philosopher with the crude commonsense of philosophically uneducated persons. I was now beginning to see in the "commonsense" which the philosopher has to interpret nothing less than the inspiration of God, who gives man a share of the Universal Reason. God was truly immanent in the spirit of man: Universal Reason was present in human experience, under finite conditions; sub-consciously or semi-consciously, in all human beings-with more or less articulate consciousness in those who reflect. To interpret this Divine Revelation by reflection seemed to be the raison d'ctre of metaphysical philosophy.

I was glad to be confirmed in my estimate of Ferrier's speculation by Hamilton, who wrote to me as follows: "I presume that I am not wrong in attributing the article on Ferrier in the 'North British Review' to yourself. It strikes me as by far the ablest review of that work which I 
have seen. It does justice both to the author's ingenuity and to his baseless paradoxes. I was particularly pleased with what you say as to the far wider compass of our Belief than of our Knowledge. It seems to me that through Belief we lay hold of many of the most important objects which we are unable to know, or even to conceive. And certainly if we were reduced to admit only what we are able to cognise-directly or through a contradiction-we should be compelled to surrender much, indeed the most, of what it is principally important for us rationally to acknowledge. I am convinced that what you say of the 'counterpropositions' is punctually correct. As far as I know, they are merely imaginary absurdities, gratuitously attributed to previous psychologists."

That "Belief is wider than Knowledge" need not, I thought, imply that Belief is mere sentiment, empty of intelligence. I began to see that faith is inseparable from finite intelligence, and that some degree of intelligence is inseparable from faith. Intellige, ut credas is not inconsistent with Crede, ut intelligas. They must coexist in finite mind and expcrience; they actually coexist in various proportions in individuals, or in the same individual, according 
to the objects with which intelligenee is engaged. This correlation is chiefly striking when God is the object to which a human understanding is directed. And so-ealled human knowledge, being at last necessarily incomplete and ineompletable, may be called knowledge or ignoranee, according to the way in which it is looked at, and the meaning associated with these two terms.

These Essays in Philosophy, contributed to the "Review," were republished in a small volume in 1856, as juvenile aids to reflection on our pereeption of, causal interpretation of, and moral faith in the Universe in which we find ourselves.

About this time the "North British Review' eneountered antagonism of a sort which remarkably illustrates the difference between the state of religious thought and ecelesiastical toleration in Seotland now and in the earlier half of the nineteenth century. Then Christianity was supposed to depend upon the verbal infallibility of the Bible, and the Bible had then to be interpreted in oberlience to intellectual formulas of the seventeenth century. Historical eritieism is now modifying this conception of the Bible; seience, 
conceiving Nature as ultimately under evolutionary law, is correcting the old conception of the physical universe; metaphysic is introducing the idea of immanent and omnipresent Deity, instead of the remote occasionally interposing Governor; and a more deeply ethical religion sees the perfect goodness as well as the judicial severity of the universally operative Power-inspiring man with faith and hope, and nourishing charity. The middle of the nineteenth century was a transition time. I had hoped that the 'North British' might serve religious thought in a degree, as the 'Edinburgh Review' had served in politics in two preceding generations. Theology, as far as it is a human interpretation of divine revelation, must be subject to change and development, although the revelation which it interprets is constant. Theological formulas depend upon prevalent philosophical conceptions. When these change the formulas become anachronisms. Explanations which satisfy at one stage in the intellectual progress of mankind, become unintelligible in the thought of a later time.

The disposition of the 'Review' to recognise this, and to give expression to reasoned advocacy of progressive as well as of conservative religious 
thought, had already called forth hostile strictures from those who looked upon the traditional form of theology as superior to change. Articles which encouraged progressive thought, or which recommended to missionaries in non-Christian countries sympathy with what is good in non-Christian religions, had raised remonstrances. A crisis came when, in 1856, the appearance of the Life and Posthumous Works of Chalmers suggested an independent estimate of his place as a philanthropist and religious thinker, for the subject of an essay in the 'Review.' In the still prevailing ecclesiastical heat in Scotland, it seemed impossible to find north of the Tweed an informed critic who was likely to preserve judicial impartiality. So I turned to Isaac Taylor, the recluse of Stanford Rivers. He had been educated in English Nonconformity; he was now a devout member of the Chureh of England; he had been long studying the morbid and healthy phenomena of religious life. So I asked him to express freely his thought about Chalmers. He did this in a critical essay which filled more than seventy pages of the 'North British.'

Very soon this performance encountered the uncompromising hostility of the chief Scottish repre- 
sentative of traditional theology. Dr William Cunningham was the successor of Chalmers, as Principal of the Free Church College. In this capacity he published an address to the students, warning them against the reviewer and the 'Review.' Taylor's criticism was described as " most erroneous and injurious in its whole spirit and tendency; there being few things," so he added, "which I should regard as worse for you and for the Free Church than that you should be influenced by the views set forth in that article; and upon all grounds I feel it to be an imperative duty publicly to testify and solemnly to warn you against it."

The justification offered for this judgment is interesting, because it shows the condition of ecclesiastical thought in Scotland in the middle of last century.

One fault alleged was, that the article put a higher estimate on Chalmers as a magnetic living influence than as a theological thinker. It predicted that his books would undergo "a sifting, which at no distant date must consign to oblivion most of what he had produced"; and this notwithstanding the stimulus which they had administered in Scotland to the generation in which 
they appeared. This opinion has been more than confirmed, by what I cannot but regard as their undue neglect and disparagement in this generation. For they have already almost disappeared, in the ever-widening torrent of printed matter, which makes literary fame more and more ephemeral in each new generation.

The suggestion that Chalmers had misgivings about aspects of Calvinism that seemed inconsistent with perfect goodness in God was another offence. Perhaps Taylor would have found more support for misgiving in the adoption by Chalmers of the Neo-Calvinism of Jonathan Edwards, than in the expressions on which he rests; for the universal necessity of Edwards seems inconsistent with the moral agency verbally recognised in the Westminster Confession.-Opinions in the article on "the infallibility of the Bible" were also among those which were pronounced "utterly unworthy of respect and confidence." The Scriptures, Cunningham said, assert their own inspiration and infallibility, and we may reasonably receive this upon their testimony. The proposed alternative of " a doctrine of inspiration which, while it should save the authority of Scripture, should allow scope for or invite the freest methods 
of historical criticism," was dismissed as "crude, inadmissible, unintelligible." - But censure fell chiefly on Taylor's hopeful anticipation of a "biblical theology" ready to recognise in an open spirit the mysterious facts in divine revelation, liberated from "superannuated logical or deductive theology." This theology, Taylor might have said, was apt to forget Bacon's warning that "perfection or completeness in divinity is not to be sought," inasmuch as in a human interpretation of divine revelation "many things must be left abrupt." Cunningham's rejoinder is an assertion that the deductive theology of the Reformation, "in its whole substance and leading features, is far too firmly rooted in the Word of God, and has been far too conclusively established, to be ever again seriously endangered."

Although Scotland has been, I daresay, the most theologically disposed country in the world, it has in the last three centuries contributed almost nothing to theological science, in consequence of the aversion of its ecclesiastical rulers to development of religious thought, and the restraints which till lately they have put upon criticism. Its range, too, in what is ambiguously called "natural theology" has been 
narrow. And it has tried to assimilate Augustinian conceptions, dominant in the Westerm Church, while it has been indifferent to Origen and the Greek thinkers. Deductive arguments, founded on ideas of limited sacrificial atonement, and limited divine predestination to final goodness, with unlimited moral impotence in man, have largely superseded thought about Trime Deity and Divine Incarnation, which engaged the early and medieval Church, as well as modern Protestant communions. That Chalmers had not risen enough above those restraints is implied in Taylor's belief in his ephemeral place in the history of religious opinion. Christianity presented in its full spiritual integrity, not artificially adapted to human assumptions,-rather with due acknowledgment of its intrinsic superiority to all finite forms of thought, - was 'Taylor's proposed way of escape from the fetters by which it had been confined, through dogmatic assumption of book infallibility instead of reliance on spiritual self-evidence. Half a century has seen a change. That is now received even as evidence of spiritual wisdom, which accepted ecclesiastical guides then consigned to a Scottish Index Expurgatorius. 
As the proprietors of the 'North British Reriew' adopted the literary policy of Cunningham, I withdrew from an editorship which could be retained only by acknowledging the sin of having invited free expression of the thought of one religious genius about another; and by a promise to exclude free treatment of the intellectual expression that was given to Christian faith in the seventeenth century. The attainment of my ideal required, in the circumstances, a more versatile and warlike editor, not confined to philosophical articles. New duties forbade me to entertain a proposal, by the most influential writers in the 'North British,' to inaugurate a Scottish Quarterly which should be independent of the obstructive influence.

Some years after this curious incident in its history the 'Review' changed its proprietors, and I returned to its service as an occasional contributor, on the invitation of Doctor Blaikie and Mr Douglas, its enlightened editors in succession in the 'Sixties. In the end, under the able editorship of Mr Wetherall, and with the co-operation of Lord Acton, it represented liberal and learned Catholicism in the Roman Church, thus ending a checkered life in 1875. 
This collision with Scottish conservative ecclesiasticism was nearly contemporaneous with the change which has since determined my career. In Nay 1856 Sir William Hamilton died. The abolition, a few year's before, of the ecclesiastical test which retained the Chairs of Philosophy exclusively for the Established Church of Scotland had deprived my office of its justification. The project of "a Free University" had precipitated this change. It was my duty to appear as a candidate for the vacant chair of Logic and Metaphysics; not without misgiving when I thought of its recent illustrious history, and when I compared myself with competitors, among whom Ferrier and Scott of Manchester were chief. But I was encouraged by the support of Cousin and Rémusat in France, Brandis at Bonn, and high philosophical authorities in England and America. A contest of uncxampled severity ensued, in the end without alienation of friendship. I enjoyed cordial intercourse with Ferrier and Scott while they lived, and afterwards with Ferrier's family, in some of the lapppiest experience of later life. 


\section{CHAPTER V.}

\section{IN THE CHAIR OF HAMILTON.}

$$
\text { 1856-1891. }
$$

"On earth there is nothing great but Man :

In man there is nothing great but Mind."

-Class-room Motto.

"Our little Systems have their day;

They have their day, and cease to be ;

They are but broken lights of Thee, And Thou, O Lord, art more than they."

-Tennyson.

I HAVE now traced the unlikely path which led to what for thirty-five years was my academic home, a welcome haven amidst Scottish ecclesiastical war, the sound of which I heard in that winter in Glasgow College, when I first looked out on life, and which had lasted since with increasing violence. I was apt to think of Locke's expression of relief after the Restoration from the troubles in which his Puritan heritage had involved him : "I had no sooner found myself in the world than I found myself in a storm; and therefore cannot 
but entertain the approaches of a calm with the greatest satisfaction. I find that a general freedom is but a general bondage, and that the assertor's of liberty may be the greatest engrossers of it too." I had at last found my work, and could pursue it under favourable conditions in the emancipated university.

In the reaction that followed the struggle of the election, and with the appalling sense of responsibility involved in the succession to Hamilton, I was encouraged by the counsel of Victor Cousin, the eloquent French advocate of spiritual philosophy, and then its most distinguished living representative in Europe. The intellectual influence of Germany had inspired Cousin in his early struggle against a dominant sensuous philosophy and materialism. Schelling and Hegel, viewed in an eclectic spirit, had led him to claim for the true philosopher an intuition of the Infinite Reality in an impersonal exercise of Reason ; and this claim, a quarter of a century before, had exposed him to the trenchant criticism of Hamilton. In later years Cousin had become less enamoured of transcendental speculation, and now looked to the Scottish philosophers, and their introspective recognition of the common-sense of humanity, for 
security against total scepticism. He seemed to find in human nature a more modest and appropriate pathway to reality than he had discovered in Germany. In the preface to the third edition of his lectures on the Philosophie Écossaise, published in 1857, Cousin referred thus to the philosophieal position in Scotland:-

"La morte toute récente de M. Hamilton est une calamité qui ne s'arrête pas aux bornes de sa patrie : elle sera longtemps et vivement ressentie par tous ceux qui d'un bout du monde à l'autre ont eonsaeré leur vie ì l'étude cie la philosophie et de son histoire. L'université à Edinburgh vient de leur donner une consolation et une espérance, en confiant la Chaire de M. Hamilton à un de ses disciples préférés, qui se fera sans doute un pieux devoir de suivre la tradition de l'illustre maitre, et de maintenir l'ir tégr: té de la Philosophie Écossaise devant le public Européen. Ce qui distingue cette philosophie, et lui donne un earactère et un intérêt particulier, c'est le bon sens; et ce qui y nourrit et y renouvelle sans cesse le bon sens, c'est l'étude assidue de la nature humaine - le haut rang attribué à la Psychologie parmi toutes les autres branches de la science philosophique. Quand la psychologie déchoira à Aberdeen, à Glasgow, à 
Edinburgh, ce jour-là, nous n'hesitons pas à le prédire, c'en sera fait de la Philosophie Écossaise: elle n'aura plus qu'ì céder la place à quelque importation de la mauvaise métaphysique de l'Allemagne dégénérée. Puissent la sagesse et la constance de M. Fraser prévenir un pareil malheur, et répondre à ce $v œ u$ public d'un vieil ami de M. Hamilton et de l'Écosse."

Without an undue surrender of liberty to tradition, I could respond gratefully to this counsel and benediction of Cousin. I resumed thought on the lines I had followed in the preceding decade, in essays already described; which, as I have said, dealt chiefly with the rationale of our causal interpretation of the universe that was at first presented to us in transitory phenomena of sense-perception, externalised for us in self-consciousness. The discussion of the ultimate foundation of our belicfs and knowledge, set agoing in Scotland by David Hume in 1738, in which Reid, Stewart, Brown, Sir James Mackintosh, and Sir William Hamilton had been leading interlocutors, had to be reconsidered by me now, at the novel point of view of the rising scientific Agnosticism, which proposed to substitute a wholly naturalistic basis of life and experience 
for the metaphysical and religious one. I had also to deal, on the opposite side, with the allcomprehensive constructive Idealism-"mauvaise métaphysique de l'Allemagne dégénérée," according to Cousin - which in some minds was displacing the native Baconian philosophy. Young Scotland seemed disposed to reverse the counsel and example of Cousin, who had turned in later life from Germany to Scotland for weapons in the encounter with agnosticism. The rising generation were attracted, some by the negations of the sensuous philosophy which Cousin had at first combated in alliance with Germany; others by the "metaphysique de l'Allemagne," from which Cousin had turned to the Scottish tradition that the young Scot was now learning to despise.

But "Philosophic Écossaise" itself, some were beginning to say, had lately spoken with a sceptical voice. Hamilton, its last and most illustrious representative, was claimed by leaders of agnostic science as a patron of agnosticism. Had he not announced an "unknown and unknowable God" as the last word of philosophy and religion? Professing relative knowledge, he was "confessing 
absolute ignorance"; and, like David Hume, he seemed in the end to leave life, and the universe in which we live, " a riddle, an enigma, an inexplicable mystery."

The publication of Hamilton's lectures on metaphysics and logic, soon after I was admitted to his Chair, was a fresh motive to a retrospect of his position. These lectures were supplemented in 1859 by Mansel's "Limits of Religious Thought," which was an elaborate application, by the most logical metaphysician in England, of Hamilton's final nescience to the defence of religion and the Christian faith.

Hamilton's "lectures on metaphysics" turned out to be those which I had listened to twenty years before, in the select class of metaphysics which startled the civic rulers of the university. After 1838 they were read to students in alternate years with those on logic, and the alternate courses formed Hamilton's official report of the contents of mind in man, delivered while he was professor. "In man there is nothing great but Mind." This was the motto of the class-room, "mind" being a synonym for spirit or soul. But what of Nind in the Universe? Ought we to say that nothing is great in the Universe but Mind? May 
we take "Mens agitat Molem" either as the fundamental postulate, or the chief conclusion, of philosophy? And does metaphysic involve reasoned belief in the immortality of man? In 1838 Hamilton had tempted us by the prospect of his lectures in metaphysics culminating in a discussion of these questions. A tripartite division of philosophy was then proposed. One part was to deal empirically with the phenomena of mind in man; and this was meantime represented by the lectures on introspective psychology, delivered under the name of metaphysics. In another course on logic he evolved the laws of thought. But the whole was to converge in "metaphysic proper;" concerned with "our ultimate inferences about unknown Being," especially the rationale of our conclusions, that God exists, and that men are immortal. The expected discussions made no appearance in the published lectures, and the proposed triplieity was even withdrawn in favour of dual courses - one on psychology, or the phenomena of mind in man, and the other on logie, or the absolute laws of thought. The final question of philosophy,whether Matter, or Mind, or Something different from either, is at the root of All, and the allied 
one regarding man's ultimate destiny, were only alluded to in occasional digressions.

By this failure of articulate metaphysical derelopment Hamilton came, I think, to be misinterpreted in the collision of agnosticism. His denial of infinite knowledge to man-a modification of the teaching of Kant-was taken as denial of all knowledge of God, under the conditions of human belief; and he was, in the sequel, accepted by Herbert Spencer and others as the parent of the science which totally disclaimed religious knowledge.

The nescience of Hamilton was emphasised by Mansel. The Oxford metaphysician argued for the possibility of religious faith by showing the finitude of human knowledge. He concluded that intellectual objections to religion come, not from superior knowledge, but from a defective conception of what human knowledge must be even at its highest. The preface to the first edition of his lectures on the 'Limits of Religious Thought' opened with the following quotation from one of my 'Essays': "The theological struggle of this age, in all its most important phases, turns upon the philosophical problem of the limits of knowledge and the true theory of human ignorance." "The present lectures," he adds, "may be regarder 
as an attempt to obtain an answer to this problem, in one at least of its aspects, by showing what limitations to the construction of a philosophical theology necessarily exist in the constitution and laws of the human mind."

But Mansel seemed to go beyond Hamilton, and to make morality in God something different in kind from morality in man. Instead of showing that, notwithstanding its mysteries, the Christian system is intellectually possible, this argument seemed to make it impossible for man ever to receive any revelation of omnipotent Goodness. If the ethics of Divine providence and grace differ totally from our ethics, how could man trust either natural or supernatural signs of a divine revelation? Does not this subvert science and morality and even the beliefs of common experience? I seemed to be living in a morally untrustworthy universe, animated by a Power whose morality may be our immorality. The Christian "revelation" itself may be intended to deceive. What we call sin may be goodness in God. Total scepticism instead of Christian faith would be the logical outcome of a philosophy which thinks of the Power universally at work as outside all the implicates of the moral reason and righteousness 
that for our conscience are supreme. How can one know anything, or believe anything, it was asked, if the Power at the heart of the universe is "good" only in a transcendental scnse,- a sense in which all our ethical conceptions may be reversed? But this was an interpretation of Mansel's teaching which he emphatically disarowed. Soon after its publication he stayed with us in Edinburgh, to receive an honorary degree from the University, and I remember how he complained of the curious determination of popular critics to overlook the conservative elements in human nature that were presupposed in his argument. Yet Mansel's language about the difference between divine morality and human morality is sometimes open to misunderstanding. It is apt to suggest that what is called dirine action may be diabolic, putting conscience and reason in man to final confusion. Faith in science and in miracle are alike impossible in a possibly untrustworthy universe.

The appearance of J. S. Mill's ' Examination of Hamilton's Philosophy' in 1865, brought to the surface the controversy between the followers of Nill and the followers of the Scottish philo- 
sopher, which was latent in the 'Fifties of last century. In an essay in the 'North British Review' I tried my hand in a sort of Eirenicon, as between Mill and Hamilton; also between Berkeley and Hamilton, in their common doctrine of an immediate perception of phenomena practically external to each percipient person. Neither attempt, I now think, was satisfactory. In the preface to the next edition of his book Mill treated my conciliatory criticism as advocacy: "The review of this work in the "North British," he said, "is attributed to Professor Fraser, and bears the strongest internal marks of that origin. This able thinker, though he considers me to have often misunderstood Sir W. Hamilton, is, on the substantial philosophic doctrines principally concerned, a most valuable ally, to whom I might almost have left the defence of our common opinions." My sympathy with the prominence given to our concrete experience by Nill, and in the English philosophical tradition from Bacon and Locke, had, I think, made me stretch conciliation too far; and the same perhaps in regard to the "immediate perception" theories of Berkeley and Hamilton. This part of my essay was the 
subject of an interesting eriticism by Doctor Hutchison Stirling in a review article.

Mill's account of the ultimate foundation of man's inductive interpretation of the world, taken as an argument, seemed unsatisfactory. It appealed finally to presupposed "uniformity of nature," while he derived the conclusion that nature is orderly from a preceding induction. I was now coming to regard the assumption of the inductive interpretability of nature as virtually an assumption that Active Reason is the ultimate motive principle of the world in which we have our being, and of which we have immediate perception in sense. Mens divina animat Molem. In all percipient exercise of the senses I seemed to find myself in intelligent intereourse with all-pervading Mind. But was this fundamental faith in Nind immanent in nature an issue of logical proof? Was it not a presupposition that is necessary to any intelligent intercour'se with the ever-evolving universe? It might well be that there was no scientific proof of this theistic presupposition: the presupposition itself seemed to be the primary postulate of all proof of any absent fact. And this growing unwillingness to accept anything without physically scicntific proof was 
unphilosophical, if all proof must rest at last on the theistic postulate. Take for granted the existence of God; assume that interpretable nature is virtually significant language in which the Universal Mind is addressing man. Do we not find the physical universe in harmony with this postulate that Divine Order is innate in its evolution? To argue scientifically for the inevitable presupposition of all inductive science is to reason in a circle: but the theistic postulate, on the other hand, I thought, might be logically vindicated, as the alternative to a reductio ad absurdum in the form of total nescience or mental paralysis.

Before Mill's 'Examination of Hamilton' appeared in 1865, other influences were inclining in a like direction. Comte's 'Philosophie Positive' had, as I have said, been recommending the physically scientific conception of the universe as the only one suited to the manhood of the human race. It was certain, we were told, to take the place of the metaphysical categories, which engaged the race in its youth, and, above all, of theology which was the philosophy of the infancy of mankind. In the progress of the ages man had outgrown explanation of the universe by metaphysical categories of thought, and could 
still less return to second childhood, by referring the phenomena of the world to the arbitrary agency of a Being external to the whole phenomenal universe. True science was inevitably confined to facts given in sense, and their sensible relations; all beyond this must be illusion. Religion and metaphysics were anachronisms. Progress in the future was to be found through suppression of ultimate questions about the "Why" or the "Whither."

The negation alike of absolute and infinite knowledge, argued for by Hamilton and Mansel, was adopted (but without their inadequately explained substitute called "belief") in the "First Principles' of Herbert Spencer, which made its appearance in 1862. This was an introduction to the elaborate 'Synthetic Philosophy' that followed, in volumes that have played a significant part in Blitain and America in the latter part of the nineteenth century. The atmosphere was charged with Spencer's synthetical exposition of the universe as an evolutionary manifestation of Unknowable Power, integrating and disintegrating in endless change. The evolving phenomena were blindly assumed to be interpretable, so that their 
sciences could be articulated in a concrete philosophy; but the Power itself, supposed to be behind the whole, we were told, must be for ever "unknown" - an occasion, it might be, of ignorant sentiment, but not of intelligent faith. The attempt to think about it must issue in intellectual confusion. We cannot suppose it to be Matter with the atheist; nor Mind with the theist; nor Substance transcending both Matter and Mind with the pantheist. Our true wisdom is not to think about it at all. It is utterly inscrutable. Yet, I was apt to say, how can this be, if I can have so much science of its manifestations? And how can the "Unknowable" be known to be a "Power"?

Thus forms of philosophy, agnostic in religion, which, in combination with the evolutionary conception of the universe, were favoured by the temper of the age, seemed ultimately absurd, because they led to universal uncertainty.

They were met in Britain and America, in the second half of the nineteenth century, by a constructive Idealism, which professed to articulate the rational constitution of the universe according to its divine ideal. The more sublime efforts of human reason in the past had tended to this. 
The spiritual impulse of Plato led to the architectonie work of Aristotle. Augustinian metaphysic was followed after a long interval by the 'Summa Theologiæ,' in which St Thomas dereloped philosophieally the Christian conception of the universe. The introspection of Descartes was the antecedent of the mathematically reasoned gnosticism of Spinoza. And in 1865 Doctor' Hutchison Stirling disclosed the 'Secret of Hegel' to the Anglo-Saxon world, while Absolute Idealism was expounded in new forms, with eloquenee and moral fervour, at Oxford and Glasgow.

Constructive philosophies engaged me in the early 'Sixties, as in contrast with the agnostic empirieism of Comte and Mill and Spencer. I made Spinoza the subject of an essay in the 'North British' in 1863, when I was beginning to make his acquaintance, before the expositions of Pollock and Caird and Martineau had reinterpreted his philosophy. The intellectual atmosphere had become charged with Spinozism,-for' the first time in Britain, unless the 'Pantheisticon' of Toland in 1720 was a sort of exception. Spinozism is elastie-interpreted by some as a gospel of pantheism; by others as the 
rationale of scientific agnosticism. Its central idea seemed to be consubstantiality of all finite things in One Infinite Substance, with mathematical deduction of finite relations, in space extended and thought, under this supreme principle. The true happiness of man was looked for in the contemplation of the infinite variety in the all-including unity of God; neither rejecting the one consubstantiating substance like the atheists, nor admitting in its geometrically necessary universe any independent agency of persons, as the theistic conception does. Sensuous imagination and discursive thought could not satisfy Spinoza. Tranquillity was to be found only in an intuition of reality, in which all was seen sub specie eternitatis, above the misleading limitations of time, in God and as God, God the only reality.

De Deo was in words the key-note of Spinoza's conception of the universe. But I pleaded that, according to his report, it was a statical and mathematically necessitated, not a dynamical and morally constituted, universe that I was living in. Finite persons disappeared in the unity of impersonal, undifferentiated Substance. When I tried to realise the Spinozistic Unity, either the infinitude of the Divine Reality or the reality 
of the manifold finite was lost. His consubstantiating conception seemed to be either empty abstraction, or subversive of postulates of moral reason on which all human experience must depend. Either all finite persons and personal responsibility vanish, or else the philosophical unity of Spinoza is an incoherent incomprehensible unity. It seemed, on one alternative, to be rightly likened to a lion's den, to which roads may lead, but from which none return; or, as by Hegel, to a formless abyss, in which actual human experience is swallowed up. On the other alternative, God was so identified with the finite universe that every act of every person must be divine-the actions attributed to the thief or the murderer equally with those of the philanthropist and the saint. To work out our own salvation, and to work out our own sin, was alike God working in us.

So, not without admiration, I turned from the vast intellectual construction of Spinoza to the all-comprehensive idealism of Hegel, which in the nineteenth century dealt with Spinoza's problem at the point of view partly opened by Kant. Did Hegel's articulation of the Universal 
Reason, innate in the universe of reality, relieve the darkness which I found in the consubstantiating unity of Spinoza, as well as in agnostic natural science with its background of total nescience. Was the Hegelian dialectic able to explain the mysteries which seemed necessarily to arise in any finite intelligence of the infinite universe? Was the rational necessity involved in abstract "categories" to be taken as the adequate intellectual interpretation of all things and persons in the concrete contingently presented universe?

So I was led to consider whether our philosophical conception of the universe into which we enter at birth, as into an unbeginning and endless stream of events, must not become at last a moral venture in faith. Must it not deal with the infinite reality as visible by us only at the side-point of a finite intelligence, not at the divine centre with the perfect vision of God? A professed intellectual articulation of the real universe incompletely revealed to us in time, emptied by philosophy of all mysteries, seemed open to like criticism with Spinoza's cruder attenıt to consubstantiate the finite and the Infinite-the many and the One-individual things or persons and 
God, who is through them "in part" revealed. A final human interpretation of experience surely could not, even at its best, be infinite science of the origin and destiny of the universe that is now evolving in time, and in which I am inrolved. Human systems can reflect God and the universe only in "broken lights," and the highest lesson and issue of philosophy must be the transformation of pure reason at last into intelligent faith.

During the thirty-five years in which I was in the Chair of Hamilton, I had to steer my course through the conflicting phases of thought which I have now described. On the one hand there was scientific Naturalism, with its dogmatic assumption of progressive and regressive evolution as final synthesis, - all beyond this, the darkness of the Unknowable. On the other side was the new gnostic Idealism, bound by its profession to eliminate all mysteries, and at last to reach infinite science of Reality.

Through defect of speculative genius, or for some other reason, I was unable to follow these guides. "Mens infinita, in ordine molem infinitam et nos agentes in mole, semper agitans," might express the causal conception of my carly Essays. But 
unless morally trustworthy "Mens agitans" was presupposed as the root of all, I was left in a totally uninterpretable universe, and the philosophy which thus proclaimed unknowableness was suicidal. If agnosticism went so far as to assume its own scientific postulates, it seemed bound to go further in vindication of those postulates: ethical or religious faith in the Universal Power seemed to be involved by implication. If the universe was not moved-animated-by Active Reason, the so-called laws of nature might be untrustworthy, and nature wholly uninterpretable. But if agnostic Naturalism, ignorant of Universal Nind, claimed too little, gnostic Idealism seemed to claim too much-if it meant that man could see the universe from the divine centre as God does; that the attainable ideal of human philosophy is perfect intellectual vision of All from this centre; instead of vision "in part," as it were from a side-point of view, but with a finite perspective absolutely attainable there. I found that I could not say, "ego sum Mens immanens et infinita." But I was perhaps too ready to suppose that all who are called Hegelians mean to identify human agency and intelligence with the infinite agency and intelligence of God. Yet 
many seemed to imply either this, or else that "God" was after all only consciousness as found in each man,-the "Universal Mind" only the aggregate of finite minds.

In this way I found myself on a Vice Medic, repelled alike from an agnostic science wholly ignorant of God, and from a gnostic science which implied Omniscience. But can a human knowledge of existence that is only "in part" be reliable or real, even as far as it professes to go-with its infinite residuum of the Unknowable, and consequent incalculable possibilities? How can I be said truly to know anytling unless I know everytling? Unknowable Power may disturb all my scientific calculations. What if the "Mens agitans molem" should be a Mens diabolica, not Mens divina? What if I have to deal, not with trustworthy but with misleading language of the Supreme Mind, when I venture to proceed upon a trustworthy uniformity of physical sequence, and so treat my perceptions in sense as an interpretable Book of God?

The thought grew upon me that the reasonable human attitude towards the universe, in the 
apparent contingency of the appearances in which it presents itself to us, must have at its root not speculative reason only, but rational faith-venture, -the "faith" composed of the entire complex constitution of man - man emotional, and man morally responsible, as well as man finitely intelligent-the venture involving an assurance that this complex constitution of man need not be finally put to confusion in the universe in which he lives and moves and has his being. This was a reasonable Venture; unless it was found to involve some express contradiction, leading to total nescience and moral paralysis. For vindication of the Venture took the form of a reductio ad absurdum-Nescience or Omniscience-for each of the extremes between which it was a via media. If I must be wholly ignorant of the Universal Mind, because I cannot comprehend infinite reality, I cannot have even the positive science which Naturalism claims; for it rests upon the Venture that the Mind universally at work is perfectly Good, and therefore sure not finally to deceive. On the other hand, the gnostic assumption that infinite reality is comprehensible in finite intelligence - all its mysteries fully resolved - is self-contradictory, 
and leads to the absurdity implied in human Omuiscience. So what is presented in the visible world and in self-consciousness must be taken as a trustworthy discourse, constantly addressed to us by the Eternal Proridence that animates the universe, directing its unbeginning and unending evolution, under perfect intellectual and moral ideals; but in terms which, while progressively interpretable, cannot be infinitely interpreted, either in the generalisations of physical science, or through the final categories of philosophical system.

I think it was Berkeley's unique problem that first sent me in this direction of thought. It was promoted by Locke and Kant and Hegel. I expanded Berkeley's divine language of vision into a universal sense-symbolism, and our moral consciousness of our own free agency into perfect moral agency at the heart of the Whole. Implicates of pure reason, which with Kant make human experience possible, led to implicates of moral reason, which presuppose the universe of reality to be morally constituted reality, although by us incompletely interpretable. I gradually came to think of this theistic faith, not as an 
infinite conclusion empirically found in finite facts, but as the necessary presupposition of all human conclusions about anything.

In 1862 I wrote a few pages for 'Macmillan's Magazine' on "The Real World of Berkeley," intended to present his "idealism" somewhat in this light-as a philosophy of the Active Causation with which the universe is eharged rather than as Immaterialism, which had been misinterpreted and then ridiculed; and this was followed by an article on his "Divine Visual Language," which I gave to the 'North British Review.' I had long before found awakening in Berkeley's juvenile dialogues, but now rather in his 'De Motu,' 'Aleiphron,' and 'Siris,' which seemed to reveal his real drift, freed from the paradoxical language in which it was at first concealed. For more than a eentury the world had in eonsequence hardly taken this theistic philosophy seriously. He had been treated as a sceptie, who refused to trust his senses; an unpractical dreamer, who discarded as unreal all that we see and handle, calling that illusion which every man at every moment of his life is obliged to treat practically as something real. And this caricature was ealled "Berkeley's ideal- 
ism." If "idealism" means this, Berkeley, I saw, was no idealist. I found in his works, taken collectively, germs of theistic philosophy more fruitful than elsewhere in our insular literature ;especially appropriate at a time when the spiritual conception of the universe was under criticism, because in collision with the "advanced" conception that things and persons all appear and disappear in continuous blind evolution, without beginning or end or purpose.

My articles on Berkeley gained more attention than I expected. In the following year the delegates of the Oxford Clarendon Press proposed a Collected Edition of Berkeley's Works, which they asked me to edit. I was at the time considering a proposal by Macmillan of a philosophical text-book; but this, for which on consideration I did not feel ripe, was readily abandoned for the enterprise to which I was now invited. I have never resumed the proposed manual. Increased experience has not encouraged the idea of philosophy being taught dogmatically from a book, instead of being thought out by the student for himself, aided by the intellectual stimulus of the university.

The Oxford 'Berkeley' became my chief liter- 
ary employment in the later 'Sixties and after. At the outset I remembered the following sentences in Southey's 'Omniana,' which appeared in 1812: "Bishop Berkeley. A journal of his travels in Italy and many of his papers remain unpublished. His grandson, George Monck Berkeley, had he lived, would have given them to the world. I know not what is become of them since the family has been extinct, but of such a man not a relick should be lost." To search for those manuscripts was the duty of Berkeley's editor. I found in a volume of 'Poems' by Monck Berkeley, published by his mother after her son's death in 1793, that "several stoneweight of manuscript" had been left to her care; I found that after her death, early in the nineteenth century, the precious documents had been transferred to Grimston Hall, in Yorkshire, to the custody of friends of the family; and that through them they had passed on to Hugh James Rose, the eminent principal of King's College, London. After his death in 1838, it appeared that they had been given by his widow to her brother-in-law, Archdeacon Rose, rector of Houghton Conquest, in Bedfordshire. After some negotiation the collection was kindly placed at my disposal by the 
Archdeacon, for the proposed Oxford edition of Berkeley.

A Christmas week at the rectory of Houghton Conquest made a delightful beginning of my work. My friends Mansel and Burgon were invited to meet me there, the wit of Mansel and the quaint humour of Burgon mingling in the evening with metaphysical discussion in the genial hospitality of that beautiful home. I revelled all day among the manuscripts to which I had been directed by Southey. Among them I found a treasure which Southey had not mentioned, in the form of two closely written volumes, forming a sort of Commonplace Book, in which Berkeley, at Trinity College, Dublin, between his nineteenth and twenty-third year, had entered his oceasional thoughts in metaphysies and ethies, as they rose freshly, and charged with Celtic ardour, on his mind. Here were the fervid speculations concerning the riddle of life of one emerging from boyhood, set down to await mature consideration afterwards, but without a presage that they might be openerl to all in a future generation. As I followed them I traced the rising consciousness of a new spiritual conception of the universe - a brave and enthusiastic genius in the pain of spiritual birth, exulting in 
the discovery of what promised to be a practical interpretation of the riddle. He was beginning to see that "the material world," as perceived by us, is only an interpretable succession of sensepresented signs; in themselves wholly impotent, for "nothing visible or tangible is known to be the active cause of anything"; and God alone as the immediate agent in the changes presented in sense; through which, as intermedia, each person can communicate with other persons, on which pleasures and pains depend, and which science enables us to adapt to our convenience, in obedience to its laws.

This Commonplace-Book, with this revelation of Berkeley's mind in early life, made me turn with renewed intcrest to the revelation of his mind in old age, in 'Siris,' and earlier in the 'De Motu' and 'Alciphron.' I compared them with the Commonplace-Book, and with the three youthful treatises on which the tradition of his philosophy had hitherto rested. In 'Siris' I found a basis of Platonism instead of the cmpiricism of his less guarded youth. In the later works, too, there was a reticence of the Immaterialism, at least in the paradoxical form that "things are only ideas." The things we immediately perceive 
in sense were no longer called ideas. In 'Siris' this misleading name was exchanged for "phenomenon." I also found a spiritual coneeption of power dominant, corresponding with my own habit of thought. The total passivity of the things of sense was contrasted with the voluntary activity of all - pervading Reason, "the only really active agent in existence." So philosophy in Berkeley began to take the form of an answer to the question about the Power at work in the universe, which had perplexed me when I was a child. "I have as much reason," I found Euphranor arguing in Berkeley's 'Alciphron,'- "I have as much reason to think the Universal Agent, or God, speaks to our eyes as you can have for thinking any particular person speaks to your ears." We can as little see the spirit of man-the conscious spirit really is the man-as we can see the Spirit that animates the universe. Both are revealed through significant signs of sense, which are objects to us all in common, immediately presented to each different person, and which all can simultaneously perceive and interpret. 'The world reveals God in the same way as the world reveals the man I see before me. The Mens divina is virtually incarnate in the universe, as the spirit which 
is the man is incarnate in his bodily organism. I pictured the universe as moved or animated by omnipotent and omniscient Mind. It formed a sense-symbolism, which was a sufficient medium of intercourse between finite embodied minds, besides largely forecasting their pains and pleasures in this life. On the ultimate relation between the natural regularity of sequence, which converts appearances presented in sense into reliable signs, -material for scientific physics, and the spiritual freedom for which persons, or moral agents, are justly responsible, I daresay Berkeley was satisfied to think that-

"Our wills are ours, we know not how;

Our wills are ours, to make them Thine."

He sees Divine Active Reason even in what are sometimes called our sub-conscious or semiconscious acts. "We are not conscious of the systole and diastole of the heart, or the motion of the diaphragm. But it must not," he says, "be thence inferred that unknowing nature can act regularly. The true inference is, that the self-thinking individual, or human person, is not the real author of those natural motions. And (as a proof of this) no man blames himself if they are wrong, or values himself if they are 
right. The same may be said of the fingers of a musician, which some object to be moved by habit, which understands not; it being evident that what is done by rule must proceed from Something that understands the rule: therefore, if not from the musician himself, from some other Active Intelligence; the same perhaps which governs bees and spiders, and moves the limbs of those who walk in their sleep." This is the omnipresent or immanent Reason that animates the universe of things and persons, and in which self-conscious persons participate.

Editing Berkeley's Works, with the relative bibliographical and biographical research, and the occasional thoughts embodied in the annotations, engaged my available time during the five years preceding 1871. The success of the attempt to make him an interlocutor in contemporary debate, between the ultimately sensuous conception of the universe and the ultimately moral or religious conception, far exceeded expectation. Berkeley now met with appreciative criticism in the chief British, Continental, and American reviews, and in many books of philosophy. Among others J. S. Mill, Mansel, Huxley, T. H. Green, Sir Alexander Grant, A. J. Balfour, Leslic Ste- 
phen, T. Collyns Simon, Dr Hutchison Stirling, Macguire, Professor T. K. Abbott, Professor Van der Wyck, M. Penjon, Uëberweg, Ulrici, Janitsch, Eugen Meyer, Professor Höffding, Noah Porter, and Kranth, in consequence delivered their thought. In 1874, at the request of the Clarendon Press, I prepared a Students' Berkeley of annotated "Selections" from his philosophical books, for use in colleges, which has gone through five editions, and is used in British and American universities for exercise in reflective thought. It was followed in 1881 by the 'Berkeley' in Blackwood's "Philosophical Classics." Nearly twenty thousand copies of these three publications have found readers. In 1899 I was asked by the Oxford delegates to prepare a fresh edition of the Collected Works. In that and the next year I was recasting the edition of 1871 , in the light of later thought and research. It appeared in four volumes in 1901. So Berkeley pursued me for more than thirty years.

Simultaneously with these operations in metaphysical literature I was delivering"lectures on logic and psychology and metaphysics for those who were learning in the class-room to think for 
themselres. In philosophy I had still to confess myself "a seeker." Perhaps the thought in the leetures and my solitary thought were kept too much apart. Perhaps I ought to have admitted the main eurrent, some of which was finding occasional exit in essays and annotations, more fully into speech. I might in this way have engaged the undergraduates in a greater degree as helpful fellow-thinkers. On the other hand, the final problems which lay in the heart of my literary work seemed hardly appropriate for those who eame to eollege to begin to think. They still needed to have "the mist and veil of words" removed, their sense of logical eonsistency made more acute, and themselves made more awake to the difference between probability and fancy in estimating evidence. One remembered that the path of human life was strewed with fallacies and sophisms, and that these were apt to be multiplied on the part of the path frequented by abstract thinkers.

The duty of the teacher in these circumstances was first of all to prepare the young philosophers to encounter fallacy and sophism, by analysing valid reasoning. Logic formed aecordingly our preamble to psychology and metaphysics. But it was of 
course the elementary logic which proposes scientific forms for the unabridged expression of reasoning, deductive and inductive; lessons in definition and method; and criteria for testing interpretation of nature in daily life and in physical science-not logic, in the high Hegelian or even Kantian meaning, concerned with the ultimate categories of thought. It bore more immediately on opening life than that. All men are daily occupied in drawing conclusions from premisses, by use or abuse of deductive or inductive methods, each concerning the subject of his own particular business. And we have had bequeathed to us a Greek Organon and a Novum Organum, for testing the consistency of our reasonings with their premisses, and also their consistency with order in nature-but without discussing the ultimate premisses of reasoning. Syllogism, whether according to the Aristotelian or the Hamiltonian articulation of its forms, was used as a sort of demonstrator's table, for exposure and dissection of concrete fallacies placed upon it for the purpose. I wanted to employ logic as the vestibule of philosophy, dealing with concrete fallacies, as illustrated in Aristotle's book of sophisms, in the idola of Bacon, or in Whately and Mill. 
Logic studied in this spirit and with this practical aim warns the student of the aptness of men unconsciously to produce fallacies in the guise of valid reasoning; but it does not pretend to satisfy the desire for absolute certainty in our actual reasonings about things. Obedience to its legislative enactments secures non-contradictoriness or self-consistency, as between conclusions and their premisses: it provides no final warrant for the truth of the premisses themselves. Premisses are concluded from preceding premisses, and so on, in an indefinite regress. Where does this chain begin, and on what does it finally hang? As a fact, we all accept most of our premisses on the authority of tradition or of experts. But what claim has tradition or the expert to infallibility? On what must human reasonings all rest at last? Why is the pathway to ultimate reality obstructed by an aceumulation of crror and fallacy?

Lectures and exercises on the practice of reasoning naturally raised those questions. They led us onwards from formulas of syllogism, and methods of inductive trial, to a reflective study of the spiritual constitution of the human reasoner —in a word, from Logic to Psychology; and 
through this to Metaphysics or ultimate philosophy, and analysis of religion.

Here it appeared that although evolution of conclusions from premisses was a characteristic and daily employment of all men, it was a mark of limited intelligence and experience. A mere animal cannot syllogise or generalise. Divine intelligence, comprehensive of the universe of reality, does not need to syllogise and generalise. Intuition of all things and eventspast, distant, and future as well as present, in all their relations-would supersede inferential interpretation of what enters into the narrow experience of each man, or even into the collective experience of mankind. Under our limiting cosmical and intellectual data, we have to employ discursive thinking, in order to reach the significance of the sensuous and spiritual realities that are presented to us in our external and internal perceptions. For these two fountains of concrete experience present only an infinitesimal portion of the universe of reality to each individual, or even to the race of man. Then all this has to be intrusted to a power of mental reproduction and elaboration that is still more limited in its recollections; losing 
much of what is intrusted to it, reviving only in fragments what it reproduces; subject to habits of mental association that are often permitted to take the place of calculated reasonings; this, too, in combination with disturbing passions of the ill-governed soul and resulting unreasoned prejudices. Locke speaks in this connection of " the narrowness that human minds are confined to here, of having their ideas revived only by succession and not all at once; whereas the several degrees of angels may have larger views, and be endowed with capacities to retain together and constantly set before them, as in one picture, all their past knowledge at once, ... wherein no one of their thoughts that they have ever had may slip out of their minds. The Omniscience of God, who knows all things, past, present, and to come, and to whom the thoughts of all men's hearts always lie open, may satisfy us of the possibility of this." Human language is an indispensable, but after all an imperfect, auxiliary in abstract reasoning, and our interpretation of the universal language of God, contained in the signs which make their appearance in our senses. The students found by experience that names did not long re- 
tain their defined meanings, but almost all became ambiguous, often did not stand in their minds for any meaning; so that words which were supposed to reveal realities were the curtain that concealed them.

Introspective psychology thus became a lesson reminding us of our human state-intermediate intellectually between two extremes. We found that man was neither omniscient nor wholly ignorant; although, strictly speaking, unable, as Pascal says, to know the parts without knowing the whole, or to know the whole without knowing the parts. In introspective study of human intelligence, we found that we had to contemplate "human souls in this low situation, in which they bear the weight and see through the dusk of a gross atmosphere, gathered from wrong judgments daily passed, false opinions daily learned, and early habits of an older date than either judgment or opinion. Through such a medium the sharpest eye cannot see clearly. And if by some extraordinary effort the mind should surmount this dusky region, and snatch a glimpse of pure light, she is soon thrown backwards and depressed by the heariness of the animal nature to which she is chained. And 
if again she chanceth, amidst the agitation of strong fancies and wild affections, to spring upwards, a second relapse speedily succeeds into this region of darkness and dreams."

Religion and metaphysics presented themselves as the two ways in which the spirit of man finds satisfaction, in the "region of darkness and dreams" in which it is left by logical understanding, when confined to the meagre data of empirical science. In religion the complex constitution of man-emotional, active, and intelligent -is found in ultimate practical relation to the Power universally at work, the Mens divina agitans molem, the Spirit that animates the universe. In metaphysic, intellect in man tries to express in thought our ultimate relation to the Supreme Rcality. The sceptical negations and ideal constructions which appear in the history of philosophy are the inadequate issucs of this trial.

Exercises in logic and in psychological introspection thus brought us at last into the metaphysical region in which the perplexities of human thought converge. The excrcises were meant to place the student in the attitude that is appropriate to a limited experience and finite intelligenee. Consciously or unconsciously, we must 
all be metaphysicians. Not least those who treat metaphysic as illusion; for if they are reasonable, they must do this for a supposed reason, and this reason is their unconscious metaphysic. But all need not be metaphysical experts, who think out their final intellectual position. Most persons are contented to accept their ultimate premisses on authority. A few desire to test the authority. So in 1865 I opened separate lectures for any so disposed. In the following quarter of a century more than 400 students entered in this class. In those lectures I avoided final system, and unfolded some of the great philosophies of the past, destructive and constructive; in the faith that human thinkers differ, not totally, but in the degree of their approach to the perfect philosophy that is fully reached by none. The history of metaphysics is in much like the history of poetry or art; yet the collisions of metaphysicians represent gradual advancement on the whole. And now the young aspirants, by going into the river, and "moving up and down in its depths and shallows," each bestirring himself as he best could, were able in the end to discover something.

This attempt to educate independent thinkers 
was not unsuceessful. The young metaphysicians of the university soon formed themselves into a Society for weekly diseussions, and the class-room, aided latterly by this "Philosophieal Society," has sent not a few professors and books of philosophy into the world, in the later deeades of the nineteenth eentury. It has given two professors of philosophy to Edinburgh, two to Glasgow, three to Aberdeen, two to St Andrews; one to Oxford, and another to Cambridge; besides a still larger number to American universities, and to colleges in India and Japan and Australia. Others are distinguished in Parliament, or on the judicial bench, and in the Church. The young metaphysicians were oceasionally encouraged and directed by addresses delivered, among others, by Mr Balfour, the present Prime Minister, Sir Alexander Grant, Professors Henry Sidgwick, Knight, Bosanquet, Jones, and the late Professor Wallace of Oxford.

But I must leave the class-room, to look at the University of Edinburgh, as it was in those years. 


\section{CHAPTER VI.}

\section{THE UNIVERSITY OF EDINBURGH.}

$$
1859-1889 \text {. }
$$

"If we were asked for what end endowed Universities exist, we should answer, To keep alive Philosophy. All things in which the public are ade'puate judges of excellence are best supplied when the stimulus of individual interest is most active; and that is where pay is in proportion to exertion. But there is an education of which it cannot be pretended that the public are competent judges, the liberal education by which great minds are formed. To rear up minds with aspirations and faculties above the common lierd, capable of leading their countrymen to greater achievement in virtue, intelligence, and social wellbeing; and likewise so to educate the leisured classes generally that they may participate in the qualities of these superior spirits, and be prepared to appreciate them, and follow their steps-these are purposes that require educational instructions placed above dependence on the immediate pleasure of the very multitude whom they are meant to elevate."-J. S. MILL.

My class for metaphysicians was inaugurated under happier academical conditions than when Hamilton made the experiment in 1838. The 'Sixties and the two following decades of the nineteenth century are memorable in the history of Edinburgh University. They saw the "Town's College," till then a chaotic aggregate of students and professors governed by the Town Council, 
transformed into a self-governed society of graduates, and reconstituted on this foundation. In the middle of the nineteenth century graduation in the fundamental or Arts faculty had been dormant in Edinburgh for more than a hundred years, and graduation in law and divinity was unknown. The European fame of the undeveloped university rested on the eminence of the professors in two preceding centuries, in mathematies, metaphysics, and medicine; and on the occasional emergence of a literary, scientific, or political celebrity from the ranks of its alumni. Monro, Cullen, Black, Bell, Christison, and Simpson were names of European repute among its medical teachers. The Gregories, Colin Maclaurin, Playfair, and Leslie were eelebrated mathematical professors. Ferguson, Dugald Stewart, Brown, and Hamilton were historical figures in psyehology and ethies. The College had enrolled David Hume, Walter Seott, Thomas Carlyle, and Charles Darwin, also Brougham and Palmerston, Lord John Russell and Lord Henry Petty, among its students. Robertson, an eminent representative of historical literature, lad presided over professors and students as Principal. Nevertheless, with the advance of the nineteenth 
century, there were symptoms of decline, aggravated by a chronic war between the professors and the Council of the city; probably, too, by the ecclesiastical war in Scotland which preceded and followed the convulsion of 1843. The influx of students, which was about two thousand annually in the first quarter of the century, had fallen in the second quarter to little more than half this number.

Yet in the end the Disruption of the Church of Scotland served Edinburgh and the other Scottish universities well. The prospect of "a great Free University," supported by the claim of a large portion of the Scottish people now outside the Established Church, as well as the intellectual value of an open field from which to choose professors, produced the Act of Parliament which in 1853 relaxed the tests that had hitherto bound the chairs to the Established Church, and opened them to the intellect of the world. Popular interest in the universities accordingly revived; there was an organised movement for reform, in which James Lorimer was a leader; and the memorable Act of 1858, which made Lord Advocate Inglis the greatest benefactor of the Town's College since 
its foundation in the days of James VI., was brought into operation in the four following years, by the Commission over which Inglis presided.

Neglect of graduation, especially in the faculty of literature, science, and philosophy, was taken as the root of the ailment from which the College was suffering. A self-governing academical Society had to be organised. As baptism is to the visible Church, so is graduation to the university. It is the sign and seal of membership. The few extant Edinburgh graduates in Arts, and (provisionally) all who had been regularly enrolled as Arts students for a term of years, were formed under the new law into a University Council, over whom a Chancellor was to preside. The professorial Senate, or Educational Executive, was in many ways strengthened and developed. A University Court was instituted in place of the Town Council in the administration; and the patronage of the chairs was transferred to a joint Board of Curators. The undergraduates were to be organised and brought into touch with academical life as constituents of a Rector, who was to preside in the University Court. Thus academically constituted for the first time in its 
history, the University of Edinburgh was launched on its new career.

In 1859 the first Chancellor was chosen by the Council, and the first Rector by the undergraduates. Brougham was made Chancellor and Gladstone Rector. Council and Court then began to exercise their functions. We all felt that it was the morning of a new life in the old College, now connected with the great world by this association with an omniscient celebrity of the past generation, and with the chief statesman of the coming age. Brougham's early ties with Edinburgh, by birth, as an old alumnus, and as the grand-nephew of Principal Robertson, were not forgotten.

Another change was coincident. In 1859 Principal Lee died, a learned and eccentric ecclesiastic. The era of lay principals opened. The most eminent man of science in Scotland was made Head of the College. Sir David Brewster, then in his seventy-ninth year, diffused academic spirit and a benign social influence among us, with the added lustre of his name, during nine following years. One of his first public duties was to preside at the inaugural addresses of the Chancellor and the Rector, and over the associ- 
ated festivals, events never to be forgotten by those who witnessed or took part in them. They were followed six years later by the impressive inauguration of Thomas Carlyle, who succeeded Gladstone as Rector, and later still when Lord President Inglis, our great benefactor, succeeded Brougham. Carlyle's discourse was heard with respectful attention by the students, but later experience makes his reception unique in the history of Edinburgh rectorial addresses.

In 1859 my colleagues in the Faculty of Arts made me their Dean, and I continued in this office for thirty-two years. In 1877 I was also sent by the Senate to the University Court, in succession to Sir Robert Christison, who had represented the Senate from the first constitution of the Court, and I retained this office also till I retired from the Chair of Hamilton in 1891. I was now for the first time in my life involved in administrative work, complex and important, especially during a period of rapid and extensive academical evolution. Although, perhaps, non natus rebis agendis, this afforded healthful occasional diversion in a life too exclusively introspective. The policy of the university and its administration alternated in my regard with 
the ultimate mysteries of the Universe. Indeed the University has been almost the only department of public affairs in which I have actively participated. I have always been deeply interested in evolutions in Church and State, yet the isolating influences of early life, meditative habit, lack of invitation or opportunity, and withal mental paralysis in public speech, have kept me, I daresay, too much aloof from the service of society in Edinburgh, in extraacademical ways.

Arrangements for adapting the new constitution to undergraduate studies, and development of graduation, occupied me in the 'Sixties. In this I was especially helped by Professor Aytoun, a congenial comrade in giving life to the new organism, whose kindly humour was combined with strong common-sense and faculty for affairs. The first public graduation in Arts was in the Assembly Hall, on the Castle Hill, in April 1861, when it was my duty to deliver the address.

The life of the university, unprecedentedly active in the thirty years which followcd the legislation of Inglis, owed much of its vigour and eharm to the personality of Sir David Brewster and of Sir Alexander Grant, who successively pre- 
sided as Principals. Brewster breathed the academic temper into the newly organised society; as a scientific ehief he shed lustre on Edinburgh, as Robertson had formerly done in literature, and as Leighton, a remoter predecessor, had done in religious thought.

Brewster was a brilliant converser, and his genial presence was always a social inspiration. But his easy flow of speech deserted him in public oratory. In this regard he might be described as a man of few words and many works. I remember him once for a wonder on his feet at a Senate meeting, his eyes fixed on the table before him, giving utterance to a single, apparently extempore, sentence expressing objection to a proposal to confer a theological decree which he conscientiously disapproved of. On passing his chair after the meeting, I saw on the table in manuscript the few words he had spoken. They were after all read, not extemporised.

When Brewster died in 1868, the rival claims of two eminent members of the medical professoriate to the succession menaced prospective harmony in the University. Either of them would have added dignity to the office, but to appoint either, as it 'seemed, would endanger the 
peace of the College. In the circumstances one was led to look elsewhere for a Principal who might reconcile all. It so happened that when Macdougall died, in the beginning of the winter of 1867 , the moral philosophy class was intrusted to me by the Senate for that session, in addition to my own classes. In defect of full lectures, I made use of books, including Grant's 'Ethics' of Aristotle, attracted by its philosophical learning and many-sided humanity. Inquiry discovered Grant's signal success in directing high education in India. It seemed that if he could be induced to come to Edinburgh as Principal, an embarrassment might be advantageously relieved. The idea grew in my mind, till one evening, on our way home from a meeting of the Royal Society, I suggested it to Lord Neaves, who at once gave it an encouraging response, and advised communication with the Chancellor and others. This led to further inquiry, and to correspondence with Grant, who with some reluctance consented to be nominated, and in the end he was made Principal. The fatigue and anxiety connected with this affair, in which I was unexpectedly involved, along with the extra work among the young moral philoso- 
phers, lectures to an outside class of logic newly instituted for women, and the pressure of the Clarendon Press for the 'Berkeley,' combined to make 1868 and 1869 the busiest years in my life.

Grant was an academical statesman and administrator of a high order, able to direct and inspire the newly organised university. In the nineteenth century he accomplished on a greater scale, and under more auspicious conditions, a work not unlike that attempted in less fortunate circumstances by his predecessors, Carstairs and Robertson, in the preceding century. By him the Act of 1858 was made a signal success. The University Council, which numbered some 1800 members at the outset in 1859, expanded to some 8000 at the close of his reign. Instead of 1200 students the now autonomous University had attracted more than 3000. Almost a million of money was poured into its coffers, from voluntary gifts as well as grants by Parliament. New buildings, which doubled the accommodation for study, fellowships and scholarships to encourage original research, and the new professorships, tutorships, and examinerships, were a magnificent testimony to the place which the University had taken in public regard, and to the wise policy of the 
Principal. His administration fitly culminated in 1884, in the Tercentenary Festival, organised and directed by him, which attracted to Edinburgh scholars and philosophers from the chief seats of learning in the world, in a congregation unprecedented in Britain. A few months later the University was mourning for his death.

I have lived under five British Sovereigns, and $I$ have seen six Principals in the College of Edinburgh. When I was an undergraduate, George Husband Baird was the Head of the College, a philanthropic ecclesiastic, who reigned for nearly half a century. He was a professorial colleague of Robertson, and afterwards his successor in the principalship, thus connecting the Edinburgh of my youth with the Edinburgh of David Hume and Adam Smith. So generations are linked and pass away.

I recall with pathetic regard those now departed to the silent land, who were colleagues when I held the Chair of Hamilton. Their welcome and confidence are remembered with gratitude. In $1856 \mathrm{I}$ found in the Senate Pillans and Forbes, who had guided me as a student in their class-rooms nearly a quarter of a century before; Macdougall, my early associate, who had 
succeeded Wilson in Moral Philosophy; and the genial Kelland, one of my truest friends in middle life. William Gregory, the latest academical representative of a name long famous in British universities, was still in the Chair of Chemistry; Simpson and Goodsir, Christison, Bennett, and Syme (who was followed by Lord Lister), more than sustained the ancient glory of the Medical School; and Playfair (afterwards Lord Playfair), the successor of Gregory, was foremost in academical administration, till he transferred his great gifts to the House of Commons in 1869 . The incisive logical faculty and admirable debating power of Robert Lee were conspicuous in the Council and Senate of the University as in the Assemblies of the Church. The loss of Aytoun in 1865 was repaired by the advent of Masson, my oldest friend, who was for the next thirty years the official representative of literature in Scotland. Then there was Fraser-Tytler, grandson of Lord Woodhouselee, beloved by all, a liaw professor and our legal adviser, and Camplell Swinton, who revived the Symposium of which I have still to speak. In the benignant actirity of Calderwood the University found no unworthy successor of those who had made the chair of 
morals illustrious. Scholarship and philosophy were allied in the many-sided personality and singular personal charm of Sellar. Tait maintained the fame of the chair of Playfair and Forbes, and the versatile genius of Blackie awakened enthusiasm, and rebuked undue regard for convention-followed in the Greek chair in 1882 by Butcher, our academic light in all the intervening years. These are some among many not less worthy of regard. I have shaken hands, I think, with about 90 professors as colleagues, in the years in which I had a place in the Senate.

Then and formerly the professoriate owed not a little of its human amenity to an institution which has not, I believe, been hitherto recognised by historians of the university. In March 1792, the year before he died, Principal Robertson asked Andrew Duncan, a professor of medicine, to call a meeting of their colleagues for forming "a social annual convention of principal and professors for convivial purposes." The meeting was accordingly held, "at the Star and Garter tavern," for the College in those days had no accommodation for convivial entertainments. The senators so summoned resolved themselves into a professorial club. They resolved 
" to dine together annually in March, in a tavern, dinner to be on the table at four o'clock, and to adjourn for tea and coffee at seven." This was the beginning of the "convention" which in the nineteenth century was known as the "Symposium Academicum," at which for a few hours in each year grave professors were transformed into playful symposiasts, by whom "wisdom was worn lightly as a flower," instead of being carried gravely as a burden. A venerable minute-book contains a faithful record of the proceedings at each annual festival. It was an axiom among symposiasts that the prosperity of the Symposium was an infallible index of the prosperity of the university. The record so far verifies the axiom. From 1792 till 1833 the feasts were held with annual regularity, and were well attended; the bill of fare and the bill of costs at each meeting were registered in artistic form, and salient oceurrences were duly chronicled. From 1833 till 1850 the Symposium was in a state of suspended animation, the cause or the effect of the languir academical life in those years. There were signs of returning animation in the 'Fifties, under the genial convenership of Camplyell Swinton the Conditor. 
From 1860 until the Tercentenary in 1884 was the golden age of the Symposium, when Aytoun and Douglas Maclagan were successively "Symposii Conditores."

The minutes yield some interesting gleanings. "At the Star and Garter" in 1792, on the motion of Dugald Stewart, Robertson, the Principal, was asked "to sit to Mr Raeburn, limner, for his portrait, to be hung in the library, in consideration of the great reputation he has obtained by his excellent writings." The portrait now in the Senate hall was the issue. The minute further tells that "thirty guineas were paid by the professors to Mr Raeburn, the limner, for the portrait, and seven guineas to Mr Liddle, carver, for the frame." The names of those who dined at successive meetings are recorded. Dugald Stewart I find was only once absent till his health failed in 1809. Thomas Brown, his successor, appeared only once as a symposiast during his ten years in the Moral chair. David Hume, professor of Scots Law, a nephew of the philosopher, was hardly ever absent during his long professorship. John Playfair was constant, so was Finlayson, professor of Logic, and Ritchie the athlete, his 
successor; but Adam Ferguson was almost always missing. "Christopher North" was pretty constant, Chalmers attended several times, and Hamilton too, when he was in the chair of History, for in the later years both of Chalmers and Hamilton the "Symposium" was dormant. In its later and golden age all professors were symposiasts, and most of them shared in the festival.

In that "golden age" differences were forgotten, and in my memory the story throughout brings back times of joy. The minute for January 1860 records that as "a peculiarly joyous" festival, "being the first which had taken place since the University received an independent constitution; that glorious erent having occurred on the 15th of October 1859, at which date the Ordinances came into operation." In the following April the symposiasts dined in the Physicians' Hall, to entertain "the Right Hon. W. E. Gladstone, Chancellor of the Exchequer, who in the forenoon had been installed as Rector of the University," and "who responded to the toast of his health in an eloquent speech." On the 18th of the next month we again dined in the Hopetoun Rooms, to entertain "Lord Brougham, who was that day in- 
stalled as Chancellor." The minute also telis that "in the course of the evening the Book containing the records of the Symposium Academicum was produced, and was examined by the Chancellor with the deepest interest." It contained the history of an institution which originated with Principal Robertson his granduncle. Later minutes illustrate the growing prosperity of the University, and the return of harmony between "town" and "gown." In 1864 Prince Alfred, then a student in the University, was a guest at our dinner. Mr Gladstone dined again in his second rectorship, and successive Rectors afterwards, including the present Duke of Devonshire. Chancellor Inglis was made an honorary symposiast and was always with us; and latterly the dinners were favoured by successive Lord Provosts and other civic dignitaries, as well as by Sir David Baxter, Doctor John Muir, and other eminent benefactors. The minute-book closes on the eve of the Tercentenary Festival. I fear that the Symposium has since returned to a state of suspended animation, not this time I trust coincident with academical decline. The record of the quarter of a century after 1859 takes up more than half 
of the Book. Bills of good fare and statistics of matriculation are common features in this curious record. Echoes of songs emanating from the muse of Aytoun or Blackie or Maclagan, and of converse in which wisdom was sometimes hid in parables, at a time "when 'twas good to be merry and wise," all seem to reach me, when I turn to this fading minute-book.

Notwithstanding external prosperity in the preceding thirty years, the hand of reform was again applied by Parliament to Edinburgh and the other Scottish universities in 1889. In its educational policy the reform of 1858 had proceeded upon traditional lines in the fundamental faculty of Arts. It retained a curriculum of study that was more adapted to exercise the higher faculties of the student than to encourage modern languages and physical science, subordinating regard for man merely as a productive instrument, and aiming chiefly at increase of intellectual wealth for its own sake-in an industrial age, impatient of ancient learning, and of religion and philosophy. The changes inaugurated in 1889, under Lord Kinnear, have opened a wider field, giving more room to the literatures and sciences of the modern world, 
thus bringing the University into closer sympathy with utilitarian interests and life. My work in the University lay in a period of less radical change, between 1860 and 1890 . It is too soon to forecast the new era. May it be even more prosperous than the last! The University, as the social organ of liberal study and progressive learning, is a constant element in every civilised community; but, like the Church, which ought to be the social organ of spiritual life, it is apt to lose true consciousness of its high ideal, and to decline into worldliness. The warning of Bacon is never irrelevant: "If men judge that learning should be referred to action, they judge well; but in this they may fall into the error described in the ancient fable, in which the other parts of the body did suppose the stomach had been idle, because it neither performed the office of motion, as the limbs do, nor of sense, as the head doth; but yet, notwithstanding, it is the stomach that digesteth and distributeth to all the rest. So that if any man thinks Philosophy and Universality to be idle studies, he doth not consider that all professions are from thence served and supplied." 


\section{CHAPTER VII.}

\section{ACADEMICAL VACATIONS.}

$$
\text { 1856-1890. }
$$

"To spend too much time in studies is sloth."

"Philosophy, methinks, at fancy's call, Might deign to follow him through what he does Or sees in his day's march."

$$
\text { -WORDSWORTH. }
$$

WheN Samuel Johnson visited the Scottish universities in his tour in 1773 , he found a low standard of learning among the students. "Men bred in the universities of Scotland eannot," he said, "be expected to be often decorated with the splendours of ornamental erudition; but they obtain a mediocrity of knowledge, intermediate between learning and ignorance, not inadequate to the purposes of common life. The students for the most part go thither boys, and depart before they are men; they earry with them little fundamental knowledge, and therefore the superstructure cannot be lofty." Yet 
he acknowledges that in one respect these universities excel. "Their division of the academical year into one session and one recess" seemed to him "better accommodated to the present state of life than that variegation of time by terms and vacations, derived from distant centuries, in which it was probably convenient, and still continued in the English universities. So many solid months as the Scottish system of education joins together allow and encourage a plan for each part of the year ; but with us in England, he that has settled himself to study in the college is soon tempted into the country, and he that has adjusted his life in the country is soon summoned back to his college." This vacation in Scotland also secures for professors, who have to act as tutors as well as lecturers during the session, time needed for spiritual recreation, and for fulfilling their important duty of extending the boundary of knowledge, by original research in the departments which they profess. This is overlooked by utilitarian critics, who demand a tale of visible work that can be measured arithmetically, and who regard the invisible operations of the meditative mind as a form of culpable self- 
indulgence. The summer vacation, which earned the applause of Johnson, is a seandal to secularist critics.

In the seventeenth century, when the academical session in the northern universities lasted for ten months out of twelve, the educational executive was exhausted by the drudgery of elementary teaching. Accordingly the universities then added little to the common stock of knowledge, or to the literature by which the world is educated. In the eighteenth century the long vacation, with its "solid months" in summer, was introduced in the philosophical classes, and so Scotland became the nursery of the philosophy which was adopted by Cousin. "Greatly more than half the distinguished authorship of our land is professorial," Chalmers reminded his countrymen eighty years ago, "and, till the present generation, we scarcely remember, with the exception of Hume in philosophy and Thomson in poetry, any of our eminent writers who did not achieve, or at least germinate, all their greatest works while labouring in their vocation of public instruction in one or other of our universities. They have not only taught philosophy; they have also both, rectified its 
doctrines, and added their own views and discoveries to the mass of pre-existent learning. They have been the chief agents in enlarging our country's science; and it is mainly to them that Scotland is indebted for her high estimation in the republic of letters." It was in the academical vacations that this work was done. It is also through the physical movement and spiritual recreation of the solid academical holiday that the philosophical professor is able to vitalise and humanise his science in the classroom. I am indeed far from supposing that in my own case sufficient use was made of the thirty-five summer vacations for which I am responsible. The retrospect is an occasion for self-reproach.

Locomotion amidst new scenes, and study in a select rural retreat, divided between them each of my thirty-five "solid" academical vacations.

Notwithstanding opportunities, I have seen only a small portion of the planet which I must soon leave. A few visits to France and the Low Countries, and a rapid tour in Italy and Switzerland, have formed my personal experience of Continental Europe. I have never seen Amer- 
ica. I have followed Berkeley over Mont Cenis, which he found "one of the most difficult and formidable parts of the Alps ever passed over by mortal man"; but his transatlantic home, with its "still air of delightful studies," is unvisited. Descartes and Spinoza I have traced in Holland; but Jerusalem, Athens, and Rome, the fountains of the religion, philosophy, and polities of civilised mankind, are known to me only through report. In the locomotive weeks of these thirty-five summers I have been-

"In London chiefly harboured, whence I roamed,

Tarrying at will in many a pleasant spot

Of rural England's cultivated vales, Or Cumbrian solitude."

My thoughts about things and persons are the thoughts of one who has seen little and observed less.

Occasional visits to London, the civic marvel of the modern world, helped to enlarge this narrow experience. In itself and its associations it was to me an epitome of the history of England; and its unresting activities, as the financial, commercial, and philanthropie centre of the world, represented the manifold activity of mankind. Its growth in population during my 
lifetime, and in complexity of social and international relations, is a signal historical phenomenon of the nineteenth century. In childhood, at the old manse in the land of Lorne, I had been taught by Goldsmith that its population was "nearly a million," and I was long wont so to think. When I first saw London in 1842 this number was doubled, and now it is above five millions. To share even for a little and superficially in this extraordinary social aggregation, without parallel in the past, was a spiritual education, as well as physical refreshment, after the nervous tension of the classroom. Somehow London had a pathetic side. Macaulay's New Zealander was apt to appear in the mind's eye, seated on the ruined arch of London Bridge, with desolation all round, the disintegrated issue of centuries of human labour. And then one was led on to imagine a more awful disintegration still, in a remoter future, when the planet itself shall be dissolved, and when the race of man, with all the spiritual riches accumulated by its successive generations, has disappeared, leaving no record or trace of their transitory existence, on one of the lesser orbs in the illimitable starry heaven. 
One favourite resort was the library of the British Museum, among the silent readers, through long summer days in the 'Sixties and 'Seventies, when I was collecting materials for the Berkeley and the Locke, entangled in the meshes of that cosmopolitan collection of the issues of mind in man. Things revolve upon each other. Some things in one book led one to turn to something in another, and the concatenation among the books was endless. It suggested the unprecedented literary outcome of mankind, for of making books there is no end. What is their destiny in the thirtieth century? Will any of the names even of those among our literary countrymen most illustrious in the last hundred years be remembered then? At any rate, how will it be in the thirty millionth century, in the unpeopled if not disintegrated planet, when all record of the intellectual labour of our human race through all its centuries shall have disappeared from the universe, after the foundering of the ship in which we now navigate the ocean of space? How many worlds, with their cargoes of self-conseious persons, have already disappeared, none of them able to transfer their record to occupants of other planetary orbs? 
I found in leisure hours what was apt to touch imagination, in visiting the homes or haunts of departed philosophers and other memorable persons, whose lives were more or less connected with the metropolis. Around the Museum, Bloomsbury was haunted by Dickens and Ruskin, as well as by Macaulay, Darwin, and Carlyle; and it was in Queen's Square, and afterwards in Russell Square, that I used to visit Frederick Denison Maurice in the 'Fifties and 'Sixties. The gardens of Gray's Inn, and the gravel walks on which, as Charles Lamb says, "Bacon has left the impress of his foot," were within an easy distance. Their spreading elms are said to have been planted by Bacon; and their "Mount," like the one in his Essay on "Gardens," is "of some pretty height, leaving the wall of the enclosure breast-high, to look abroad into [what were then] the fields." From this home of Bacon's middle life one crossed to his birthplace "at York House in the Strand," or travelled to the site of Lord Arundel's house in Highgate, where he died. Fetter Lane, too, was near Gray's Inn, and there Thomas Hobbes settled himself in 1651 "in a small house, for the advantage of intellectual society," removing 
later on to Salisbury House, then to Queen Street, then to Newport House, and in one of the years after the Restoration, Sydenham "met old Mr Hobbs walking one day in the Pall Mall," not long before he left London for good, to die in the Derbyshire house of his patron the Earl of Devonshire. Exeter Hall in the Strand, now a centre of missionary philanthropy, was another attraction. It was the site of Exeter House, which in the middle of the seventeenth century was the abode of the first Earl of Shaftesbury, and thus for years the home of John Locke, when he was the medical adviser and confidential agent of that mysterious politician. Then there was Thanet House in Aldersgate, to which Shaftesbury and Locke moved after the Restoration; also associated with the third Earl, famous in the history of English Ethics as author of the "Characteristics." One followed Locke to "Chamnel Row, in Westminster, where he lived for two years" on his return from exile in Holland, "in hired apartments, in the house of Mrs Smithsby"; years in which the "Essay on 'Toleration,' the 'Treatises on Civil Government,' and the famous 'Essay concerning Human 
Understanding' issued from the press; and then to Lincoln's Inn Fields, where he lodged on occasional visits to London in his old age, during the idyllic years with the Mashams at Oates on the border of Epping Forest. At another time I found myself with Berkeley, among his patrons and literary allies, when he lived in "Portugal Street" (now Piccadilly) in 1713, on his first visit to London, calling for Swift in Bury Street when Swift was writing his journal to Stella, going with him to dine at Mrs Vanhomrigh's, or to the Court at Kensington, or meeting Addison and pastoral Philips in the Mall, ready to walk with him in St James's Park; or in Albemarle Street, where some years later Berkeley lodged "at Mr Fox's, an apothecary," when he was negotiating with Sir Robert Walpole about the Bermuda Mission; or again after his return from Rhode Island, when he passed nearly two years in "Green Street, Leicester Square," not left till he went to occupy the episcopal palace at Cloyne. Addison, too, was seen in imagination, first in "apartments in the Haymarket," in 1710, and after that in the quaint recesses of St James's Place, till he moved to Holland House, after the ambitious 
marriage with Charlotte, Countess of Warwick. Pope, the philosophical poet of his time, I could see in his boyhood, "near Hyde Park Corner, at Mr Deane's academy, where he helped to get up the play founded on an adventure in Homer, when the gardener appeared as Ajax"; or afterwards "at 9 Berkeley Street," and again "at Mr Digby's, next door to $\mathrm{y}^{\mathrm{e}}$ Golden Ball and $\mathrm{y}^{\mathrm{e}}$ second terrass in St James's Street." I visited the metaphysician Samuel Clarke in his rectory at St James's Church in Piccadilly; likewise the Rolls Chapel, in which Joseph Butler, placed there through Clarke's influence, delivered himself of those "deep and sometimes dark discourses" which formed a turningpoint in the history of moral philosophy in England; and Butler could also be found in Hampstead, where he lived long after, often visited by Secker, in what was once the residence of Sir Henry Vane, with its rich gothic sculpture and painted glass, not far from the house in Highgate in which, in the following century, Coleridge discoursed about "object" and "subject" to wondering listeners. Sir Isaae Newton I could see in Jermyn Street or in St Martin Strect, and Milton in any of his many London 
houses, one of them not far from the tombs of Bunyan and Watts and Defoe in Bunhill Fields.

For many years the Athenæum Club has been my favourite London home. Like Matthew Arnold, I have found it "a place in which one could enjoy something resembling beatitude." The still recesses of the magnificent library are haunted by the shades of almost all the great Englishmen of the nineteenth century. Mark Pattison thought this "the most delightful room in the world." In the history corner Macaulay wrote his Essays and his English history; Thackeray sent his proof-sheets to the press from the table in the south-west corner, Lord Lytton composed his novels at another, and Hallam, "much renowned for Greek," consulted a schoolman, a jurist, or a moralist at a third. I picture dear old Doctor Chalmers, elected a member of the Athenæum in his later years, visiting it for the first and last time only a few days before he died, when he met Whewell of Cambridge on the ontside steps, and then sat with him "at our little table, where we talked and took our respective sodawaters"; unable to find "kale and beef" for din- 
ner, and reduced to accept as a substitute "for the kale a plateful of mock-turtle soup, and calf's foot for the beef"; then hurrying in a cab to Chelsea to the Carlyles, "she remarkably juvenile-looking still," he a "strong-featured man, of strong sense," where "we were all most cordial and coalescing; his talk not at all Carlylish, rather the plain and manly conversation of good ordinary commonsense, with a deal of hearty laughing on both sides." Of the Athenæum Club it has been said that there are few soluble problems which could not be solved at once by some one to be found between four and six o'clock within the confines of what is one of the most delightful intellectual and social centres in the world.

The "London Metaphysical Society" was an institution eminently representative of intellectual life in England in the third quarter of the nineteenth century, when physical evolution claimed to be the universal and ultimate constructive conception of the universe, as illustrated by Darwin and unfolded in the synthetie philosophy of Herbert Spencer. This Society was formed in 1869 , on the suggestion of $M_{r}$ (now Sir James) Knowles, in co-operation with Tennyson, Dean 
Stanley, and Mr Pritchard. It was an arena for discussing principles in dispute between the advocates of a finally physical, and the advocates of a finally metaphysical or religious, conception of the universe. Discussion was to be in the spirit of inquiry and intellectual integrity in which the Royal Socicty for instance considers the problems of physics. It was to be a centre for friendly exchange of ideas between scientific agnostics and religious thinkers, with a view to a better understanding of conclusions and premisses on each side. The Society lived for about twelve years. Here is a complete list of the members, in the order of their election: Dean Stanley, Prof. Seeley, Roden Noel, Dr Martineau, Dr Carpenter, James Hinton, Prof. Huxley, C. Pritchard, R. H. Hutton, W. G. Ward, W. Bagehot, J. A. Froude, Alfred Tennyson, Prof. Tyndall, Alfred Barry, Lord Arthur Russell, Right Hon. W. E. Gladstone, Cardinal Manning, J. T. Knowles, Sir J. Lubbock, Dean Alford, Sir A. Grant, Bishop Thirlwall, Fred. Harrison, Father Dalgairns, G. Grove, Shadworth Hodgson, Henry Sidgwick, Prof. Lushington, Bishop Ellicott, Mark Pattison, Duke of Argyll, John Ruskin, Robert Lowe, Grant Duff, W. R. Greg, Prof. A. 
Campbell Fraser, Sir H. Acland, Prof. F. D. Maurice, Archbishop Thomson, J. B. Mozley, Dean Church, Bishop Magee, Prof. Croom Robertson, Sir J. F. Stephen, Prof. Sylvester, Dr Bucknill, Dr A. Clark, Prof. Clifford, Prof. St George Mivart, M. Boulton, Lord Selborne, John Morley, Leslie Stephen, Sir F. Pollock, Dr Gasquet, Prof. Upton, Sir W. Gull, Prof. Clarke, A. J. Balfour, James Sully, A. Barratt. In the twelve years about 100 meetings were held and 95 papers were read, each the text for the evening's discussion. The meetings were monthly in eight months of the year. I had the honour to be elected in 1871 , and was for the most part a silent but not inattentive listener, and this only once or twice annually, as visits to London permitted. Those evenings at the Westminster Hotel or the Grosvenor Hotel, the frugal meal, and the interchange of thought, are memorable in my London retrospect.

In the Metaphysical Society the riddle of the universe was engaged with on many of its sides. Philosophy of causation in some of its numerous phases; the relativity of human knowledge; verification of beliefs and the foundation of belief; questions about matter and what is meant by its 
being "real"; the conception of a human soul and its personality; natural and supernatural agency, and the meaning of those ambiguous words; the personal immortality of man and his future after physical death; the meaning or meaninglessness of the term "God"; the universality and necessity, or the merely occasional rise, of the problems of metaphysics and theology in the history of the human race; the nature, evidence, and spiritual value of physical miracle; free agency and its implied moral responsibility as an ultimate spiritual fact in ethics; the new conception of evolution, in its application to nature and man, and in its relation to theism; what death means, and what distinguishes the soul before and after death; the various meanings of materialism; the monistic and the dualistic ultimate conception of the universe; absolute truth, and the possibility of a human knowledge of Absolute Being, - these are examples of questions that were considered in the Society.

The raison d'être of metaphysics and theology, and of a metaphysical or theological Society like this, came up in several forms. Are problems, like the origin of the universe, its moral government, the spiritual personality of the human 
animal, and the prolongation of his existence after death-questions which men have been asking from the beginning-are these destined to be for ever asked and never answered to the satisfaction of all men? Is there any essential human need for continuing to ask them? May they not be the unhealthy issue of individual or racial idiosyncrasies, or of special cireumstances, at particular times and in partieular places? If they eannot be answered, is it reasonable to persist in raising them? May we anticipate a time in the progressive evolution of human intelligence when men will cease to raise insoluble questions, and become aceustomed to their absence? Are not such questions peculiar to savage and half-educated periods in the history of mankind? It was at the Metaphysical Soeiety that Huxley gave curreney to the term "agnostic," in its popular aceeptation of religious neseience-combined, as it seemed inconsistently, with physical scienee.

It was worth a visit to London to hear Martineau in friendly debate with Huxley, and Manning or Ward arguing for supernatural faith with Tyndall or Clifford, and to follow the subtle reasoning of Gladstone in an encounter with the outspoken seepticism of some of the associates. I do not know 
that the Metaphysical Society, in the twelve years of its life, solved, with the consent of all, any of the many problems which were raised at its meetings: perhaps such social meetings are not well fitted to promote progress in disposing of questions which appeal to the contemplative mind. But I think it helped to moderate controversy between the leaders of opposite sides in contemporary thought, and promoted mutual respect instead of mutual contempt or aversion among those who desired, each in his own way, to gain a victory for truth. The collision of Agnostics with Anglican and Roman advocates of biblical or ecclesiastical authority was always interesting, and conversation, for instance with Ward and Huxley, I always found congenial. Ward was the author of the 'Ideal of the Christian Church,' notable in the old tractarian days at Oxford. Newman and Carlyle, J. S. Mill and Herbert Spencer, were conspicuous by the absence of their names in the roll of the Metaphysical Society. Spencer I used to meet occasionally at the Athenæum. I found him a grave and serious converser, who might outwardly be mistaken for a nonconformist presbyter. $\mathrm{He}$ was reserved in philosophical talk, but what he said and wrote was refreshing as the honest 
expression of the insight of a thinker who was unburdened by philosophical learning. He did not seem, however, to have so sounded the depths of metaphysies as to appreciate the rationale of religion. As to libraries, perhaps he would have said, like Hobbes, that "if he had read as many books as other philosophers, he might have been as ignorant as they." But the intellectual and moral persisteney that produced the 'Synthetic Philosophy' is hardly equalled in English philosophical literature. I last met him when he joined me at luncheon in the Athenæum some years ago. Our talk was not about " first principles," but about his own pathological symptoms, and his adventures in quest of health at Ardtornish, and in boating on the Sound of Mull.

It was in this decade that I saw both J. S. Mill and Carlyle for the last time. I dined with Mill in April 1873, when he was in Victoria Street, Westminster, and found the same luminous speech and gentle benevolence as had appeared when I was introduced to him in Leadenhall Street nearly a quarter of a century before, and afterwards when I visited him at Blackheath. On that last day he recounted interesting talk with Jeremy Bentham 
in walks in and around Westminster when the century was young; and Bentham's house, he said, was within a few yards of where we were seated. $\mathrm{He}$ spoke of the current of politics, and of the conservative reaction that was growing in the early 'Seventies, and how the natural time for a Conservative Cabinet, and when it was useful, was when great changes were not ripe for legislation. $\mathrm{He}$ spoke of France, and of finding more religion in rural France than in rural England. The Roman Church was, he thought, more successful than the Anglican in sustaining popular religious life and in its hold of the lowest class; as for Positivism, it had probably more disciples in England than in France. Next day Mill left London for Avignon, and three weeks later he was dead.

My last visit to Carlyle was some years after this. I found him in solitude in the famous upper chamber of the house in Cheyne Walk, and was regaled for a full hour, in a benign spirit, a contrast to the cataract of denunciation to which I had listened in 1850, when I first met him. He spoke tragically of early days at Kirkcaldy, partly through obstructions to daily immersion in the salt sea, all presented in vivid pictures. The monologue was easily diverted to ex- 
perience in Edinburgh University, where there was put before him "such philosophy as was then and there dispensed, not much to profit withal." Some of it was served up by "a dainty gentleman, we called him Missey Brown, who spoke about eause and effect, and neatly divided the spiritual life of man into faculties and states, and who was said to be an imposing figure at tea-parties." There was more true manhood, as it seemed, in "stalwart Ritehie, who then professed logic, was great at eurling, no ingenious contriver of neat little partitions of the divine spirit in man." "But a truer thinking man than either, you have got now," he said, "in David Masson, sincere and sure of purpose; very brave, for he has undertaken to write a history of the universe from 1608 to 1674, calling it a 'Life of John Milton.'" Masson somehow led to Mill. He had known John Mill well, he said, when they were together in London in the 'Thirties, but now he seldom saw him. Mill was "weak in body and thin in thought, satisfied with a sort of phantasmagoria universe, without going to the heart of things." There was too much of this nowadays. Some people called "scientifie" had made a great discovery, 
so they said. They had found out that God was protoplasm; and to worship this strange god, spelt with a little "g," was a great advance, forsooth, upon the God of Israel. It was truly an ugly spectacle, which recalled an event in his own young life, when there was a sudden outbreak in the Solway Moss, out of which issued loathsome creatures-toads, frogs, and lizards: a picture of this sort rose before him when he met worshippers of the god protoplasm. "The older I grow," he said at last in a solemn way, "and I am now near death, the oftener I return to a lesson I learned when I was a boy. I was told that the chief end of man was to glorify and enjoy the great God. Can you give me anything better; or better than the prayer that I make every morning- 'Thy will be done'? What more can any man's prayer ask for than this?" A cordial grasp of the hand immediately followed these words, and I saw Thomas Carlyle no more. ${ }^{1}$

In 1860 I was asked by Lord John Russell to take into my family his eldest son, afterwards

1 I mentioned some of this talk with Carlyle on the same evening, at a dinner in London, where an American journalist was of the party, and some time after I found an imperfect reproduction of it in an American newspaper. 
Lord Amberley, with the desire that his son might find in Edinburgh University a revival of his own experience there. Ill-health in after years disappointed the high promise of Lord Amberley, who studied with ardour in Edinburgh. His personal attraction, acute intelligence, and thoughtful religious spirit, as well as keen political and philanthropic interests, notwithstanding unusual constitutional reserve, presaged an influential public career, which death ended tragically in 1876. Two years before, Lady Amberley and their only daughter, my god-child, died. Lady Amberley's charm as friend and hostess, when they lived at Fife House in Whitehall, the house which Lord Liverpool lived in when he was Prime Minister, must be a sunny memory to those who shared in its brilliant reunions, in 1867-69, or afterwards at Rodborough and at Ravenscroft. Her mother, Henrietta Maria, wife of the second Lord Stanley of Alderley, in the Dover Street house, is a charming figure in my London retrospect, with her many-sided intelligence, outspoken criticism, and true kindness, connecting as she did the society of our day with the life and personalities of two preceding generations, who was able to recall meetings in 
childhood with the widow of Charles Edward at Florence, more than sixty years after Culloden. Mention of Dover Street recalls delightful visits to Alderley and to Castle Howard.

Pembroke Lodge in Richmond Park revives happy experience of many annual visits there after 1860. One sees the low rambling structure, two storeys high, the walls concealed by creeping plants, the windows opening on the noble terrace, which commands in its near view the Thames from Hampton Court to Richmond, and beyond this the great plain of Middlesex with Windsor in the distance. But the interest lay still more within. I had heard Lord John described as cold and aloof in public life, but found an unexpected contrast in the genial kindness of the host at Pembroke Lodge in his union of gentleness with firmness. His early Edinburgh life was not forgotten in after-dinner talk. He had lived for three years with John Playfair, the celebrated mathematical professor; and he had listened to the lectures of Dugald Stewart and Thomas Brown in 1809-10. It was the college session in which ill-health obliged Stewart to have recourse to Brown for help during part of the winter. When the philosophical veteran returned to work, 
he received an address from the students, which Lord John, the students' chairman, presented to him in person. He spoke with admiration of Stewart, and with warm regard of Brown, the "Missey Brown" of Carlyle. Then there were stories of Fox, and of Holland House in the days of the Regency, of Spain when he was there with Wellington, and of Elba when he met Napoleon. For one who, as a boy at the lonely manse in Lorne, had been so absorbed in details, of the great struggle for Reform that the speeches and divisions, the contested elections and riots, were all engraved on my memory as no later incidents of the sort have ever been since-the interest was great now to have the record from the chief actor. $\mathrm{He}$ often returned to the parliamentary eloquence of Plunket, the political genius of Canning, and the attractive personality of Daniel O'Connell. To be a leader of the House of Commons, Lord John said, "I found three rules indispensable." The first rule was "Patience"; the second rule was "Patience"; and the third rule was "Patience." He spoke of Sir James Mackintosh, whose philosophical articles in the 'Edinburgh Review' had been my favourite reading in former days. I asked Lord John how my intellectual hero marle 
so little way in the House of Commons and on the official ladder. "Lord Grey," he said, "thought Mackintosh too much a dreamer, and too dilatory in his ways for administrative work, - too "sicklied o'er with the pale cast of thought." It was Coleridge, I think, who used to say of Mackintosh, that he was the king of the men of talent, uncommonly powerful in his own line, but that not the line of a first-rate man.

Emerson was in England in 1873. I met him several times at Pembroke Lodge and in London, and afterwards he visited us in Edinburgh. The insinuating sweetness of his manner was a contrast to the prophetic anathemas of Carlyle, and his pervading sense of the spirituality of the universe brought one into moods not unlike those encouraged by Berkeley in 'Siris' or by Wordsworth in the 'Excursion.' Mrs Grote and "the historian," J. A. Froude, Browning, and Mr Lecky, were also interesting apparitions in those days.

Among the cherished memories of far-off summers, none are more fragrant than those left by visits to Stanford Rivers, for forty years the secluded home in Essex of Isaac Taylor, the author of the 'Natural History of Enthusiasm,' my old 
collaborateur in the 'North British,' the friend of Chalmers, and "the bête noire of Principal William Cunningham." Although Stanford Rivers is only thirty miles from London, it seemed, when I first saw it on a summer evening in 1859 , to lie as remote from the great world as an island in the Hebrides, the house among green fields in the vale of the almost motionless Rodon. Twenty years before I was familiar with a picture of the place, drawn by Sir James Stephen, in that delightful "imaginary autobiography" of the "Historian of Enthusiasm" which first appeared in the 'Edinburgh Reriew,' and was republished among Stephen's 'Essays in Ecclesiastical Biography.' I entered the quaint farm cottage with its eosy low-roofed rooms, the library and passages overflowing with books - prominent among them Augustine and Origen and St Thomas with his mediæval compeers; early folios of Bacon and Locke, in due subordination to Fathers and Schoolmen, beside works of Anglican and Nonconformist divines; first editions of Hooker and Howe, of Joseph Butler and Isaae Watts. Then came the incisive questions and pregnant aphorisms of the venerable recluse, as we occupied the arbour in the old-fashioned garden, 
its walks adapted to meditative purposes, or traversed the lanes of Essex to Navestock or Ongar. The stillness of the leafy lanes of Essex is diffused through his books, the favourites of a departed generation, as they appeared in voluminous succession in the forty years following 1822, -discursive and rhetorical, imagination sometimes superseding dry reason. His early literary ideal was a pathology of the ailments of the Christian Church, in six volumes, on "Scepticism," "Credulity," "Enthusiasm," "Fanaticism," "Spiritual Despotism," and "Ecclesiastical Morality." Only three came to birth; other themes were more attractive, - unlike the lifelong persistency of Comte and Herbert Spencer. But some of the digressive volumes, I think, formed his best work. The contemplative thought in "Saturday Evening" is full of individuality; and the "Physical Theory of Another Life,' if too "physical" for the evidence, is full of curious speculation. Those who remember with affection Bemerton and Olney, Rydal and Herstmonceaux, will not forget Stanford Rivers and the vale of Ongar.

Although Isaac Taylor inherited nonconformity, yet sentiment and imagination, combined with reason, overcame inherited influence, and in the 
end carried him to his true home in the Anglican Church. The dual personality with which Sir James Stephen credited him - nonconformist yet Anglican-had disappeared before my first visit. The splendid vision of the historical Catholic Church, which attracted Gladstone, had been realised by Taylor with increasing force. I remember his expression of regret about his book on 'Ancient Christianity' - directed against AngloCatholicism, at the height of the Oxford movement-as too unsympathetic towards the Christianity of the early centuries. But the attraction of the historic Church never abated charitable regard for the modern sects that originated in the ecclesiastical convulsion of the sixteenth century. His father, in the first quarter of last century, occupied "the modest yet not unornamented abode" provided for the good pastors of the nonconformist congregation at Ongar to whom he ministered. According to report "a mild and venerable man," no vindictive political partisan or self-assertive sectary; in temper I should think like Watts or Doddridge, in spirituality like Bunyan or Baxter. His 'Scenes of British Wealth' and other books for children were among my early favourites, at a time when the 
prolific authorship of his wife was providing favourite reading for my mother.

One incident in the early life of these admirable persons I recall, among the reminiscences with which Isaac Taylor used to enliven our evenings at Stanford Rivers. In the latter part of the eighteenth century, his father, the future pastor at Ongar, then newly married, lived at Islington exercising his vocation as an artist. One night his wife awoke, startled by a dream wonderfully like reality - a room in a quaint old house in a rural village, furniture and surroundings visible in minute detail; the near outlook from the window a lane, bounded by a wall, on the wall "May 1691," distinctly presented. The dream was repeated on successive nights, and its vividness as well as the repetition occasioned much talk at the time in the family. With the lapse of years the dreams were forgotten. Meantime the artist had become the dissenting pastor. He had been asked by the congregation at Lavenham in Suffolk, a place which neither he nor his wife had ever seen, to settle there as their minister. He accepted the "call," and the pair went to Lavenham to engage a house. They saw and entered a house advertised "to let." On entering it, the lady to 
her surprise at once felt as if at home in it. The furniture and surroundings all seemed strangely familiar, and the outlook from the window presented a lane, bounded by a wall, on which "May 1691 " was inscribed. The long-forgotten dreams at Islington were recalled. No explanation of this curious occurrence had ever been suggested. "If this was accidental coincidence," I was asked, "can we say of any coincidence that it must be the issue of design?"

The vale of Ongar is associated with a name more known to the world than that of the meditative recluse at Stanford Rivers. John Locke spent the last fourteen years of his life at Oates, five miles from the home of the Taylors, in the parish of High Laver. Oates was then the seat of Sir Francis Masham, whose wife was a daughter of Ralph Cudworth. When Locke was living in "Mrs Smithsby's apartments, in Dorset Court," after his return from Holland in 1689, "by some considerably long visits to Oates," as Lady Masham records, "he made trial of the air of this place, and he thought that none would be more suitable for him. His company could not but be very desirable for us; but to make him easy in living with us, it was necessary he should do so on 
his own terms, which Sir Francis at last assenting to, he resolved, if it pleased God, here to end his days-as he did." An excursion to Oates was one of the pleasures of my first visit to Ongar, repeated in later years. It was a Scot, Taylor told me, that he had once before conducted there, for he had made a pilgrimage to Oates in 1825, with his visitor, Edward Irving, a much interested companion.

The old manor-house, in which the last fourteen years of Locke's life were spent in a beautiful domestic life, is not now to be seen. The Masham family disappeared with the death of the last lord in 1776, when Oates was bought by the Palmers. Thirty years later the house was pulled down by a new possessor. I have an engraving in which it appears as it was when Locke lived in it, - a square mansion, in Tudor style, an ornamental lawn and open pond in front, a turret above the entrance hall, near it the window of the room in which the philosopher wrote the many volumes of his later years, next to it the window of the room in which he slept, and beneath the two, the snug parlour in which Esther Masham, the daughter of his host, a bright girl of seventeen, used to 
read aloud to the family "in the winter evenings, after supper," some of 'Astrea,' then a farourite romance, as well as books of voyages and travels of which Locke was fond. We visited the tomb of Locke beside the parish church of High Laver, a mile from Oates, and saw the spacious pew in which he often worshipped. The Father of English philosophy, and the meditative Englishman with whom I was staying, both found their tombs within the same rural expanse in Essex. The remains of the one rest in the churchyard at High Laver, and the other lies in the churchyard at Stanford Rivers. Both were nurtured in English Puritanism and Nonconformity, and both-still "in communion with the whole Church of Christ by whatever names Christ's followers please to call themselves" -in the end found the freedom which they loved in the Church of Hooker and Cudworth. ${ }^{1}$

From Stanford Rivers my wife and I went to Cambridge, for some days of happy experience in the house of my good friend Alexander

1 After Taylor's death, I retained happy intercourse with the family in annual visits to his son, the fourth Isaac, at Settrington rectory, where he kept the "family pen" busy, as the acute and accomplished author of 'Words and Places' and many other' books. 
Macmillan the publisher, then rising into fame. Another visit to Cambridge followed in 1862, to share in the academic festival on the installation of the late Duke of Devonshire as Chancellor, and in the hospitality of Whewell at Trinity, as well as Macmillan. The visit to Whewell was interesting. I had made his acquaintance through his books in controversy with Mill, and also by correspondence as a North British Reviewer. I had been attracted by his essay on 'The Plurality of Worlds,' where it is argued that our planet is probably the only world in existence that is occupied by intelligent and morally responsible persons; the stars of heaven being a material panorama existing only for the sake of the human inhabitants of one small globe. This paradox, we are to-day told, is fully fortified by "scientific proof" that the earth is mathematically placed in the centre of the limited portion of space which, according to the theorist, contains the whole material world. And all this is taken as an apology for the faith that a divine incarnation has been realised upon this apparently insignificant planet, for the sake of persons otherwise unfit occasions of the stupendous transaction. But I do not see 
how science can put a limit to the space occupied by suns and their planetary systems, or how the universe can be proved to have any boundary, within a space whose circumference must be nowhere and its centre everywhere; or even a limit within time, in its unbeginning and unending duration. It seems a poor theistic conception to suppose God incapable of incarnation in man, unless this planet were thus unique in space and time. With the infinite fund of Omnipotent and Omniscient Goodness, what need to exaggerate the place of man, in order to justify his recognition, even according to the full economy of the Christian revelation.

In hypotheses of this sort surely physical science is transgressing its own legitimate limits, and making too free with our narrow experience of the qualities of matter. Is science even entitled to take for granted that the material world must present to all sentient beings the same qualities as it does to us with our few senses? I remembered the philosophic romance of $\mathrm{Vol}$ taire, in which Micromegas, an inhabitant of the Dog Star, asks the secretary of the Academy of Science in the planet Saturn, how many senses the men on his globe have. "We have seventy- 
two senses," was the reply, "and we are every day complaining of the smallness of the number; we are also for ever complaining of the shortness of our lives, for they seldom exceed fifteen thousand earthly years." "If I did not know that you were a philosopher," Micromegas replied, "I should be afraid of vexing you when I tell you that our lives are seven hundred times longer than yours, and that we have one thousand senses." Now we have only to suppose that not one of the seventy-two senses of the Saturnian, not one even of the thousand senses of the Sirians, corresponds to any of our five senses, in order to see that their material world must for them be destitute of all the qualities which ours manifests, yet endowed with a thousand qualities which are inconceivable by us, as colours are by a man born blind. And as the planetary orbs could have no inter-communication, we are obliged to suppose that the issue of all intellectual work pursued in each, however various and prolonged, must disappear from the universe, when each founders at last in the infinite ocean of space.

Repeated Oxford visits in those years recall Pembroke College and the hospitality of the 
Jeunes, the Mansels in the High Street and A. P. Stanley in Christ Church, at a later date week-ends with Jowett at Balliol, and later still delightful visits at Corpus. Pembroke recalls a meeting with Lord Palmerston in 1862, when he was Prime Minister. He had come to Oxford to receive a D.C.L. degree, and was staying with Jeune, who was then Vice-Chancellor. Palmerston's frankness when I was introduced to him made talk easy, and one forgot that this genial English gentleman had been a colleague of Perceval and Lord Liverpool, war-secretary when Waterloo was fought, and long a chief agent in the affairs of Europe. He talked freely about Edinburgh, told stories of his life as an Edinburgh student, when he went there in the last year of the eighteenth century, to spend three years in the house of Dugald Stewart, at the foot of the Canongate. $\mathrm{He}$ spoke of walks on spring mornings to $\mathrm{St}$ Bernard's Well, then "far in the country," or round Arthur's Seat, - all with a recollection of places, and of their history in the annals of the old city, which made an Edinburgh citizen feel ashamed of his own ignorance.

In the summer of 1870, accompanied by $\mathrm{my}$ wife and eldest son, I spent several weeks in 
Ireland in imagined companionship with Berkeley, whose life I was then writing. We visited his birthplace, beside Dysert Castle in the valley of the Nore; the famous school at Kilkenny, in which he was trained; Trinity College, Dublin, in which his new conception of the universe began to germinate; and Cloyne, where his philosophic thought was consummated. We passed a night in the episcopal palace at Cloyne, his home for eighteen years, and also some days in the neighbouring country. We saw the study from which the 'Querist' and 'Siris' issued, - "the garden of four acres, full of fruits," - and "the winding walk, nearly a quarter of a mile long, adorned for a great part of its length by a hedge of myrtles six feet high," planted by his own hand, "each with a ball of tar put to its roots," the walk in which he was wont to meditate, in that "remote corner" of Ireland where, as he said, "many modern things escape me," while "ambitious projects, intrigues and quarrels of statesmen, things I had formerly been amused with, seem now to be a vain, fugitive dream." Here, musing on the distress of Ireland, he rose from the particular to the general, and anticipated principles that Hume and Adam Smith afterwards presented in a more elaborate form. Mr Balfour 
describes the 'Querist' as " the most original of all the mass of literature on the distresses of that distressful country. The gospel of industry and self-reliance is preached on every page." It breathed love for all his countrymen, in a way that unhappily was then strange in an Irish Protestant ecclesiastic. He asks, "Whether a scheme for the welfare of the Irish nation should not take in the whole inhabitants?" and "Whether it was not a vain attempt to project the flourishing of our Protestant gentry, exclusive of the bulk of the natives?" These are among his pregnant social queries. They were illustrated in his conduct; responded to by the Catholics of his diocese, during the rising in Scotland in the '45, and again when he was thanked by the Catholic elergy for his letter, asking for their co-operation in inculcating forethought and industry among the people. Mr Wyndham has legislated in the spirit of the first query, but a university acceptable to the Catholic majority of the nation still appeals to two contradietory consciences in Britain. One of the pleasant memories of our visit to Ireland is the bright summer day spent at the College of Maynooth, where we were entertained by Doctor Russell, the President, of whom Newman says that 
he "had perhaps more to do with his conversion from Anglicanism than any one else." We found him, as Newman describes him, "gentle, mild, unobtrusive, uncontroversial."

In 1879 I was again called to literary work by the Delegates of the Clarendon Press. The alternative of an edition of Bishop Butler's 'Analogy' or an edition of Locke's 'Essay' was put before me. I was attracted to the 'Analogy' by the definite moral interest of its intellectual field; but there was the early felt charm of Locke, and the remembrance that Hamilton had made it a matter of reproach to "Britain" that "the world does not possess an annotated edition of the "Essay.'" So in the end Locke was preferred; and by good fortune for the 'Analogy,' as the Oxford edition, which has since appeared, has come from one whose name is fit to be associated with that of Butler. As for the edition of Locke, increased academical work in Edinburgh led to indefinite postponement of that enterprise. But meantime I contributed the "Locke" article to the 'Encyclopædia Britannica,' and this, with the 'Berkeley' for Blackwood, in 1881, sundry articles in reviews and ency- 
clopædias, and some minor miscellaneous essays, formed my scanty tale of literary work in the 'Eighties.

As Berkeley carried me to Ireland, so Butler and Locke tempted me in those years to locomotion in England. Two sombre days in spring were spent at Stanhope, in the upper valley of the Wear, realising the rural retirement in which Butler was buried when the 'Analogy' appeared in 1736. The pathetic solitude of that moorland country, seen, as I saw it, under a clouded sky, harmonised with the grave temper in which the recluse thinker contemplated the mysteries in the moral government of the universe, and concluded that although "many persons take for granted that Christianity is not so much as a subject of inquiry, but is now at length discovered to be fictitious," we may nevertheless, as reasonable men, "be as much assured as we are of our own being, that it is not so clear a case that there is nothing in it." The question for a reasonable man was not, he thought, whether the evidence for religion was satisfactory, but whether the evidence for a religious course of action was such as, "taking in all circumstances, makes the faculty within us which is the guide 
and judge of conduct determine that course of action to be prudent." Butler asked himself at Stanhope, what the wise final venture is for man, under conditions which make conduct of life in this mysterious universe only a balance of probabilities? That Butler struggled in vain to prove by empirical evidence the conclusion that the universe in which we find ourselves is fundamentally spiritual and moral-instead of making this the necessary presupposition of all proof of anything-was a consequence of his philosophical system, which distrusted what looked like conjecture. I was not more successful than preceding visitors at Stanhope, on a like mission, in getting light upon this part of the life of Butler. Parish books with his autograph, correspondence and contracts about church repairs, levies for rates with his signature, subscriptions in lists for philanthropic enterprises, his sun-dial and its characteristic motto, "Ut hora, sic vita, 1727," 1 are scanty Stanhope relics which I saw, memorials of the great religious thinker who was there, "not dead, but buried." I found a few more in visiting afterwards Bishop Lightfoot at Auckland, a successor worthy of Butler, dignified by his

1 Butler was rector of Stanhope from 1726 till 1738. 
learning, and among the noblest examples of the Christian life I have ever known.

With Locke the case was different. The biographical material was abundant. I had already mused among the scenes in Essex in which the last fourteen years of his life were spent. In 1879 I turned to Somerset, where he was born, and where he spent his first fourteen years. A short walk from Pensford, a village six miles south-east from Bristol, brought me on a summer evening to the farmhouse of Beluton, the modest home of Locke's childhood, and the centre of the little property which he inherited from his father. The house stands on the slope of one of the orchard-clad hills which bound the fertile vale of the Chew. It was here that Locke "no sooner found himself in the world than he found himself in a storm." The fourteen years were those ending in 1646, when his father was often away from home in the service of the Parliamentary army. Wrington, a few miles from Beluton, was Locke's birthplace: his mother was visiting there when he was born. At Wrington I found the two-storied thatched cottage, a few yards from the parish church, under the shadow 
of the Mendip hills. The tomb of Hannah More and her four sisters was beside it in the churchyard, with Barley Wood in view, where she provided schools for the peasants, entertained Wilberforce, and helped to educate Lord Macaulay.

Locke's visits to Somerset, after he went to Westminster School in 1846, were occasional and short. His friend Edward Clarke of Chipley, to whom his little book on 'Education' was written in the form of letters, was the chief link to his native county in middle life. The Clarke family is extinct, and Chipley has disappeared; but the relics of Locke which it once contained have been transferred to Nynehead Court, a mile away, where the Sanfords now represent the Clarkes of Chipley. Through the kindness of Mr Sanford, I had opportunity, during a visit at Nynehead, to examine the Locke and Clarke correspondence - some three hundred unpublished letters, many of them written in Holland in the years before the Revolution, when Locke was there as an exile. At Nynehead I found a curious picture of Locke, with Betty Clarke, whom he called his "little wife," by his side. Locke loved and was lored by children, and the funniest letters and messages used to pass between the two. The picture was evidently a 
jeu d'esprit; but there was another of Locke by Kneller, taken earlier than the common ones; likewise another picture of Betty. Locke's attentions may have helped to spoil the young lady, for she gave trouble afterwards, but at last settled into a humdrum life as the wife of a Bristol merchant. I found in the Nynehead correspondence an explanation of Locke's intimacy with the Cudworth family, which led in the end to his rural life at Oates. Mrs Cudworth, Lady Masham's mother, was intimate with the Clarkes of Chipley; and her husband, the leading "Cambridge Platonist" divine, was like Locke a native of Somerset-a region fertile beyond most parts of England in men of genius. Mrs Cudworth's name, and her daughter's, occur often in the letters, as living with the Clarkes, either at Chipley or in London.

After Locke's death in 1704, half of his library and much of his copious correspondence passed to his nephew Sir Peter King, now represented by the Earl of Lovelace; and after Oates was sold by the Palmers (the successors of the Mashams) in 1805, some remaining Locke relics, then carried away, were in possession, I was told, of Miss Palmer at Holme Park near Reading. During a visit there I enjoyed two manuseript volumes, contain- 
ing over two hundred letters preserved by Esther Masham, most of them her correspondence when Locke was living at Oates. The lively details of the family life in those distant years opened the Essex manor-house as it was two centuries ago, and seemed to make the inhabitants, with Locke a chief figure, all live again. The chair in which he studied at Oates was at Holme Park. It was frail and worm-eaten, suited to an invalid, and one of short stature.

By Lord Lovelace (the son-in-law of Byron) I was invited to Horseley Towers in Sussex, and allowed to examine under his direction the treasures conveyed from Oates to his ancestor Sir Peter King, "A catalogue of my books at Oates," in Locke's writing, was an index to his library. The works of Descartes, Nicole, Malebranche, Gassendi, and Paseal, with Bacon's 'Novum Organum,' were a few among the books; also Newton's 'Principia,' "from the author," many others in philosophy, with books of voyages and travels in great number; all beautiful in dress, and Locke's autograph in most of them. A receptacle, with twelve drawers and ten pigeon-holes, which was once in his study at Oates, was in the "Locke library" at Horseley Towers. It contained many hundreds 
of letters and accounts, carefully docketed and placed as he left them in 1704, a signal example of methodical habits. His books of income and expenditure, from 1664 till his death forty years after, gave evidence of strict and even pedantic economy. A large manuscript volume-entitled "Intellechy," and "De Intellectu Humano," and "An Essay concerning the Understanding [Knowledge, Belief, Opinion, Assent]" - showed the "Essay concerning Human Understanding" in its early growth, and the author's hesitation about the title. The fascinating summer day with Locke in the library at Horseley Towers so carried one back into the old centuries that an interval was needed to restore the sense of surrounding realities.

Our summer in 1887 was interesting. It was the year of Queen Victoria's Jubilee. We spent the first part of June at Freshwater in the Isle of Wight. Our stay there recalls a day with the Tennysons at Farringford, and a walk with him on the Downs. I had visited Farringford in 1860, when I remember him mowing in his garden, witl his two boys near him at play. Now he was less ready for manual work and more silent-an abrupt 
striking sentence now and then, in all a beautiful picture on that summer day. I returned to London for the Jubilee. A few days before, I had gone to Windsor with Sir William Muir, our Principal, and Sir William Turner, as a deputation from the University. Our reception by the Queen was preceded by a luncheon, at which my immediate neighbours were Lord Granville and John Bright. I had met Bright before at the house of his brother-in-law, Mr M'Laren, in Edinburgh. The gracious smile of Queen Victoria at the presentation which followed is an abiding memory. On the Jubilee day the morning sunshine, the vast assemblage in the Abbey, contemplated from the front of the eastern gallery, the Queen, the Prince Imperial, and the Royal family immediately beneath, with the amenity of the great crowd outside, were features in the historic scene.

Either in the vale of Grasmere or in the vale of Yarrow we found our rural home in most of the thirty-five academical vacations, during those months that were claimed for studious retirement. Rydal Lodge, and Dale End on the hillside above the lake of Grasmere, with "its green island, and 
its winding shores," were in turn our centres of life in the country of Wordsworth and Arnold. Matthew Arnold at Fox How, the attractions of Fox How and its society, including IV. E. Forster and Lord Coleridge, Doctor Cradock, Principal of Brasenose, and our old friend Bonamy Price, then an occasional resident in Westmoreland, are among those now departed to the silent land who are associated with our summers at Rydal and Grasmere. The poct's garden at Rydal Mount, in which we were allowed to walk, the long descending valley from Dummail Raise to Ambleside seen from Dale End, the walks on Loughrigg, or beyond to "the little lowly lake uplifted high among the mountains" of Langdale, more distant rambles to Keswick and Buttermere, Ulleswater and Wastwater, are among the abiding memories of that north-western corner of England.

Our connection with Yarrow was more prolonged. For some months in most of the thirtyfive summer vacations we lived there among the green rounded hills of the Scottish Border. I was first introduced to them during a visit to Mossfennan, in the moorland pastoral country of the upper Tweed, the romantic home of $\mathrm{my}$ old 
college friend William Welsh, the laird of Mossfennan and pastor of the church at Broughtona farourite resort for half a century of my life. It was in 1849 that with Welsh I crossed the hills that separate the Yarrow from the Tweed, and first felt the pensive charm of the Border vale in which a few ycars later we found a summer home - the most restful region I have known in the journey of life. Its grey shadows are associated with Berkeley and Locke, with both of whom I lived there in thought; but the silent vale between Selkirk and Moffat is connected still more with the friends whose visits added so much to the natural charm, and with neighbours in manse and farmhouse-that manse among the mountains, the centre of the social system in the happy valley. The book of 'Reminiscences' of Doctor Russell, who was for forty years the loved pastor of Yarrow, carries one back into daily life in a past generation, in a region that fed the historic imagination of Scott and the meditative muse of Wordsworth. The author, who fitly personified the romantic vale in which his life was passed, attracted his flock to goodness by the power of example. His gracious manner, gentle and refined, with 
his treasure of local legends, made companionship charming. While other parishes in Scotland were disturbed by ecclesiastical strife, there was peace in Yarrow, and Doctor Russell found in my old friend Thomas MacCrindle, the Free Church minister, the congenial temper which united them in labour for the common good.

Sir David and Lady Brewster visited us in Yarrow, I think in 1862, when we took them to the famous hostelry of "Tibbie Shicl," which he had not seen for forty years, - a visit then well remembered by the venerable hostess. I remember how Sir David that day eagerly discussed the circumstantial evidence of murder, given at one of the three famous murder trials (one of them then going on) which made a name for Glasgow in the middle of last century. Grant, Brewster's successor, Lord Napier and Ettriek, Blackie, Alexander MacMillan, and Alexander Russel of the 'Scotsman,' Sellar, Jowett, and the Amberleys, also Mrs Ferrier, daughter of "Christopher North, whose humorous sallies and brilliant talk kept us all in unbroken hilarity for a week,are among the departed whose figures now pass before me in connection with our life in Yarrow. My lifelong friend, John Veitch, Glasgow pro- 
fessor of philosophy and Border poet, had his summer home near Peebles, and was often with us. Our last parting was at the Gordon Arms inn in Yarrow, where we were staying in 1894, a fortnight before he died. While life lasts a tender pathos invests the pastoral vale.

"I see-but not by sight alone, Loved Yarrow, have I won thee;

A ray of fancy still survives,-

Her sunshine plays upon thee." 


\section{CHAPTER VIII.}

\section{IN TENEBRIS LUX.}

1891-1904.

"Who knows not Melville's beechy grove,

And Roslin's rocky glen;

Dalkeith which all the virtues love,

And classic Hawthornden?"

-Scotr.

"The eye by long use comes to see even in the darkest cavern; and there is no subject so obscure, but we may discern some glimpse of truth by long poring on it. Truth is the cry of all, but the game of a few. Certainly where it is the chief passion, it doth not give way to vulgar cares and views, nor is it content with a little ardour in the early time of life; active perhaps to pursue, but not so fit to weigh and revise. He that would make a real progress in knowledge must dedicate his age as well as youth, the later growth as well as first-fruits, at the altar of truth."-BERKELKY in 'Siris.'

"A man's religion, if it is genuine, contains the summed up and concentrated meaning of his whole life; and indeed it can have no value except so far as it does so. And it is even more obvious that the theology of a plilosopher is the ultimate outcome of his whole view of the Universe, and particularly of his conception of the nature of man,"-Dr EDWhind CAIRD.

IN the spring of 1891 I resigned the Chair of Hamilton, in the hope that it might be occupied by one fitted to inspire academic youth at a point of view better suited to the new generation. I had also a desire to "weigh and revise" my own philosophical position, mndisturbed by the 
cares of the classroom and of academical administration. So I bade farewell to the university, with which, as student, graduate, and professor, I had been connected for almost sixty years, and to the romantic city which I had enjoyed during two generations.

My hope for the Chair of Hamilton, and through it for the university as well as for philosophy in Scotland, was happily realised in the appointment of my distinguished successor, who fitly represents philosophy in the city of David Hume, Adam Smith, and Dugald Stewart, Sir William Hamilton and James Frederick Ferrier.

A short time before I withdrew from the Chair, I had found a rural retreat at Gorton, ${ }^{1}$ in the valley of the Esk, on the charming woodland of "classic Hawthornden," not less favourable to study than the Land of Lome in which I began to think, nor for opportunity of communion with Nature in the evening as in the morning of life. According to Sir Walter Scott, "no stream in Scotland can boast of such a varied succession of the most interesting ob-

${ }^{1}$ More than sixty years ago Gorton was the summer home of "Christopher North." 
jects, as well as the most romantic and beautiful scenery, as the Esk can." The surrounding historical and personal associations are not less attractive than the natural charm. Carberry, Rullion Green, and Prestonpans awaken memories of what was characteristic of Scotland in each of three successive centuries; Arniston and Melville recall historic names; also Dalkeith, Newbattle, and Dalhousie; Lord Woodhouselee made his beautiful home the Holland House of MidLothian before Craigcrook was opened; the cottage in which Scott lived in his youth, and the cottage to which De Quincey retired in age, are in the valley of the Esk; William Drummond, the cultured poet in a rude and stormy time, and Robert Leighton, his contemporary, its derout and tolerant religious mystic, lived, the one at Hawthornden and the other at Newbattle; Finlayson, afterwards the Edinburgh Professor of Logic, dark and silent Church leader, was minister of Borthwick in the later years of the eightcenth century; Robertson, the historian of Queen Mary and Principal of the university, was born in Borthwick manse, in the early part of the same century ; and Borthwick Castle was a residence of Mary, from which she fled in disguise to Dunbar. 
In this situation it was natural and easy to resume thought, and in a modest way attempt to reduce arrears of that contribution to the philosophical library which, I suppose, is the duty of a Professor of Philosophy, as much as communication of inspiration in the classroom.

The first work in which I engaged in this new home was a biography of Locke for Blackwood's Philosophical series. It provided an exit for some of the personal incidents and critical thought connected with Locke that were consequent upon the pilgrimages already described, and might, I hoped, be an atonement for indefinite delay of the projected Oxford edition of Locke's 'Essay.' This little 'Locke' was my chief employment in 1890. It took its place beside 'Berkeley' in the same series, and it was followed some years later by a similar biography of Thomas Reid. Berkeley, Locke, and Reid are characteristic representatives in the modern world severally of Irish, English, and Scottish philosophy.

The 'Locke' for Blackwood, as it turned out, was no escape from the more formidable under- 
taking to which I had been invited years before by the Clarendon Press. Soon after the little volume had made its appearanee I was asked by the Oxford authorities to proceed with the 'Essay.' I had some doubt whether a reproduction of Locke's 'Essay' in the proposed form would be responded to in the way the colleeted edition of Berkeley's Works had been. For Locke had already fulfilled his mission of awakening philosophical eriticism of human knowledge and of its limits, and of diffusing the spirit of free inquiry which has since pervaded the eivilised world. If he had not gone deep enough in his eriticism of experience to meet the wants of sceptical thinkers, and if the ambiguity of his own philosophical position made a eoherent interpretation of the 'Essay' difficult, he had at least indueed Hume destruetively, and Kant construetively, to continue what he had begun.

In the end my early interest in Locke's personality, and desire to promote an edition of the 'Essay' under the auspices of Locke's own university, involved me, in 1891 and the two following years, in what proved to be the most laborious literary undertaking of my life. But Locke's philosophical ambiguity - not un- 
natural in a work of the kind, when "written by snatches after many long intervals of interruption," by one engrossed in public affairs during a troubled period-could not conceal the noble love for truth and intellectual liberty which breathed through his work, nor its wise commonsense, congenial to the Anglo-Saxon temperament. But aversion to mysticism, and dread of intellectual bondage under "innate principles," as he interpreted that term, made Locke habitually pause and hesitate, when he approached ultimate questions about the universe and human life.

Editorial study of the 'Essay' led me to reconsider my own philosophical position, in the light of Locke's discussion of the chief problem of his 'Essay,' which he was the first among philosophers deliberately to propose in the form in which he presented it. I had become accustomed to conceive the universe of things and persons as united in their successive evolutions in and through Divine Active Reason; creation, as constant and continuous, without known begimning or end; and external nature as essentially and actively "supernatural," in the dialect of theologians, or "metaphysical," in the language of philosophers. Renewed study of the 'Essay' 
made me ask anew, whether this position was consistent with the narrow limits of my individual knowledge, or even of human knowledge. Should our final conception of things be a merely cosmological or a teleological conception? Is the unity which makes the universe a universe, a blindly physical unity, or is it intelligent and moral? Above all, is man able in any reasonable way to determine this unique and transcendental question? The seeming contradictions which underlie or pervade the physical and the moral world, make this a strange sort of universe to be claimed as divine. The darkness was not much illuminated by Locke's own final pronouncement, on one of the last days of his life, that the Whole depends on "what, for want of a right and distinet conception, is by us called Mind-Eterual Mind."

The 'Essay' proposed to test the legitimaey of my philosophical position. Can man diseover whether the universe ought to be conceived as a spiritual unity? Locke told me that his great enterprise originated in the eonviction that " the first step towards satisfying several inquiries that the mind of man was apt to run into was, to take a survey of our own understanding, examine our 
own powers, and see to what things they were adapted." Till this was done, he "suspected we began at the wrong end, and in vain sought for satisfaction, whilst we set loose our thoughts into the vast ocean of Being." This did not at first sight at all encourage human conclusions or inquiries about the supreme Power in the universe of reality, as to whether it is ultimately and essentially unknowable or intelligible. In trying to settle this, may we not be only "letting loose our thoughts in the vast ocean of Being"? Locke himself was far from saying so; although his war against "innate principles" has been interpreted in a way that leads to this.

That variety of appearances in which the universe of reality successively presents itself to us, through our five senses and in our self-consciousness, forms, according to the 'Essay,' the entire material of human knowledge. In observing those two sorts of appearances-the outward and the inward-we get all that a human understanding can in any way concern itself with, or can at all elaborate in the shape of science. "The innate principles," that were dogmatically assumed by Descartes and others, were for Locke illusions due to prejudice or to pride of reason. Homo 
mensura, aut nulla mensura, was Locke's final test. Human experience of phenomena, in the five senses and in self-consciousness, forms man's ultimate measure of what is real. Yet in many parts of his 'Essay' Locke tacitly proceeds upon assumptions for which the isolated phenomena, called by him "simple ideas of sensation and reflection," afford no warrant. He thinks he can "demonstrate" the existence and the attributes of God; thus making the aforesaid finite experience yield an infinite conclusion. He finds rational necessity in apparently contingent premisses; - unless something has been added by him, without acknowledgment, to the empirical data of external and interual sense. Thus tacitly retaining some elements of constructive reason and spiritual philosophy, he engaged British and foreign philosophical thinkers of the eighteenth century in a more profound criticism of the inevitable implicates of experience. The watchword of Locke's 'Essay' was "experience." I found in David Hume his sceptical successor. For Locke's “experience" was interpreted by Hume as unmixed contingency; without credit given for the rational assumptions which distinguished Locke's attitude. 
As for Hume, I found the essence of his teaching in a few sentences of his 'Enquiry Concerning Human Understanding.' In one of them he puts his main question, and in the others he answers it. For he asks, as a subject worthy of curiosity, "What is the nature of that evidence which assures us of any real existence and matter of fact beyond the present testimony of our senses or the records of our memory?" In other words, is there anything in reason that explains our inductive inferences regarding what is neither felt sensation nor remembered sensation? For this, according to the empirical interpretation of Locke's 'Essay' (now become the current philosophy), was the measure of the extent of human knowledge. Hume's own answer to his question was, that "reason" does not enter at all into that "enlargement of experience" in which we are wont to go beyond felt sensation and memory. "Whenever the repetition of any particular act produces a propensity to renew the same act, without being impelled by any reasoning, we always say that this propensity is the effect of Custom. By applying that word we pretend not to have given the ultimate reason. Perhaps we can push our inquiries no further, or 
pretend to give the cause of this cause, but must rest content with it as the ultimate principle which we can assign for all our conclusions from experience. It is sufficient satisfaction that we can go so far, without repining at the narrow limits of our faculties, because they can carry us no further."

But could they, under these conditions, carry us even so far? I asked. Could we have even sense-perception or memory, in any intelligible manner, to advance from? And as the "advance" was described as a physical effect, not our rational act, nor one that presupposed Active Reason at work among the data of "experience," I had no guarantee for the trustworthiness of the supposed sequence; nor could I find satisfactory meaning in the "causality" attributed to "custom." Does not reason presuppose the immanence of Divine Reason in the universe, to let human experience work? In a possibly insane experience all who share in it may be insane too; for human sanity presupposes the sanity of the universe. Blind naturalism acknowledges no security for the trustworthiness of nature, and the constancy of its uniformities; yet it (unconsciously) abounds in dogmatic assumptions 
THE ENGLISH PHILOSOPHICAL SUCCESSION. 289

which it disclaims. I found that I could have no cosmology without teleological postulates.

Thus I saw in Hume-not in Berkeley, as was commonly supposed-the immediate successor of Locke. It is common in histories of philosophy to present Bacon, Hobbes, Locke, Berkeley, and Hume as, in chronological and logical succession, the leaders of English philosophical thought. But Bacon and Locke seemed unfitly classed. Both find more in "experience" than phenomena, connected mentally by the physical influence of "custom." And Berkeley, the Plato of AngloSaxon philosophy, after more than a century of explicable misinterpretation, was found earnestly engaged with the fundamental problem of modern religious thought, - the most tremendous that can engage the mind of man. 'Siris,' his latest expression, is much more akin to Plotinus or Hegel than to Hume; and his philosophy has explained itself sympathetically in a generation saturated with Kantian and Hegelian conceptions. Blind Custom, Hume's ultimate constructive "influence," found its later English advocates in Hartley, the Mills, and Spencer, and its scientific application in physical psychology: they have added little that is philosophical to the 
negative criticism of Hume. Nor are they the only later English representatives of philosophy. Coleridge, Richard Price, and Carlyle have more in common with Kant and Berkeley than with Hobbes, or Hartley, or Priestley.

In Scotland and in Germany I found deeper and more reasonable answers than his own to Hume's question, with full acknowledgment of what Locke had ambiguously assumed. Reid's "common sense" was common practical reason: the criticism of Kant was an attempt to exhibit articulately the rational implicates of experience. Experience was the watchword of Kant as well as of Locke, but it was looked at on opposite sides by each. What is contingent in experience chiefly occupied Locke: Kant was more engaged with the universalities and necessities of pure reason, which give meaning and cohesion to experience. The mind of the eighteenth century was dominated by Locke, but the spirit of Kant has ruled science and theology in the nineteenth; and the 'Kritik' of Kant is complementary rather than contradictory to the 'Essay' of Locke. Each died at the beginning of the century of which he became the intellectual monarch; and curiously the same year is the centenary year of the 
death of Kant, and also the bi-centenary of the death of Locke. ${ }^{1}$

A few days after I had sent the last sheets of 'Locke' to the Clarendon Press, in April 1894, I was surprised one morning by an announcement that I had been chosen by my own university as their Gifford lecturer on Natural Theology, in succession to Professor Pfleiderer of Berlin, who had just then completed his two annual courses. Whilst I was grateful for the unexpected honour, I was at first indisposed to undertake an office which, if interpreted by the example of preceding Gifford lecturers in Edinburgh and the other Scottish universities, was concerned with historical Science of religions more than with the Philosophy of religion or of theism. Besides, the short interval of six months between this announcement and the delivery of lectures, instead of the eighteen months commonly given for preparation, seemed insufficient for recruiting my resources.

But after examining carefully the Deed under

1 Kant died in 1804, on the 12th of February, and Locke in 1704, on the 28th of October. The British Academy has in 1904 commemorated the centenary of the death of Kant, and has resolved to commemorate the bi-centenary of the death of Locke. 
which those remarkable lectureships were lately founded in the Scottish universities, and also a pamphlet in which Lord Gifford suggested his own religious thought, I found that a Gifford lecturer was expressly invited to discuss fundamental questions about the constitution of the universe, and man's relations to its Supreme Power, which had haunted me in youth, and during my tenure of the Chair of Hamilton. "Natural theology," in "the widest sense" of the term natural, was the subject proposed; and Lord Gifford's writings implied that the pantheism of Spinoza was in his view, as one example of what he meant by "natural theology." He asked whether the Unica Substantia of the Amsterdam Jew contains the final rationale of existence. Is human life, and all that exists, ultimately rooted in Unica Substantia? Does philosophy resolve itself into a monism; and is this monism mechanical? is it moral and therefore superior to material conditions? or does it centre in Something different from either blindly necessitated mechanism or active spirit?

These, I thought, were questions about which I might have something to say. As the foregoing story shows, my thought had been lead- 
ing up to them for the greater part of my life. There was, indeed, little time for more thinking, or for penetrating more deeply into the enormous literature of the subject, which would be more likely to confuse than to concentrate. But something, it seemed, might emerge from a sincere attempt to present the philosophical faith to which I had made my way, and the foundation in reason on which it was rested. So I resolved, with this in view, honestly to make the attempt. Consciously or unconsciously, we are all metaphysicians, if not theologians; for we all act upon, although we do not actually think out, an ultimate theory of things. Our ultimate conceptions may differ theoretically, but not to an equal extent practically. "A distinct universe," as Thackeray says, "walks about under your hat and under mine." "What a different pair of universes," Carlyle suggests, "presented themselves to Newton and to Newton's dog Diamond, while the painting on the optical retina of both was most likely the same." So, I said to myself, let me present the universe under my own final conception of it, for what in reason that may be worth.

I found a starting-point in the spiritual 
conception of ultimate reality to which reason had seemed to lead me, and which had been my sheet-anchor. MENS semper sustinet, et in ordine agitat, Molem had been its formula. I remembered a query of my acute and vivacious friend, Bonamy Price, proposed years before, and intended to evoke argument, at a time when the law of natural evolution was intoxicating the scientific world by its magnificent promise, and apparently all-comprehensive ability to perform. What, he asked, is to be the fate of religion and theology in the future, under the prospective victories of evolutionary science, which seem to be gradually withdrawing all events from God, and transferring them to "natural causes"? Much of what happens around us and in us has been naturally explained. May not the universe and all its changes be naturally explicable? But if science continues to discover natural explanations of things, and thus gradually expels the religious explanation, what room can remain in the end for any divine action? Must not God be superseded, as a superfluous abstraction, an illusion dissolved by natural interpretations of all things?

Price's question proceeded upon a common view 
of divine action in the physical universe. God was of old invoked to explain only what seemed to be inexplicable by natural causes. But the universal agency of Active Moral Reason, which I had been led, as I thought by reason, to believe in, reversed this popular conception. The more fully "natural" causes were revealed by science, the less was seen of God, according to the old idea. That every new discovery of a natural cause was a fresh revelation of God, had become my habitual conception. If all active causation or Power, as seen at our point of view, must be spiritual-if natural law is only the grammar of the divine language of nature-then positive science, instead of extinguishing metaphysics and religion, must deepen and enlighten both. Cosmical change is then the immediate issue of omnipresent and omnipotent Will: the unbeginning and unending evolution of the universe of finite things and persons is the continuous miracle, or constant supernatural activity, which constitutes nature: the whole natural order is an orderly aggregate of divinely established signs, which enable us, by their regularity, to forecast the consequences of events, as well as to refund events into their constant and 
continuous antecedents. Constancy of sequence converts into intelligible symbols the passive phenomena that are included in sequences.

Practically speaking, the physical and moral Order of the universe was accordingly another name for God; for it was in and through presupposed Order that God was revealed to us. The ultimate conception of the universe, which I had been gradually forming, inverted the answer that was supposed in Price's question. Increased knowledge of natural causes was really increased knowledge of the Divine Active Reason that was immanent in them all. Nature was always actively supernatural. And the cosmological conception of the universe postulated the teleological as underlying it in reason. So I thought my Gifford lectures might present $(a)$ an exposition of this answer to Price's question; (b) the rationale of the answer; and $(c)$ its justification, in the face of one obtrusive fact which seemed to contradict theistic faith.

I had found the old idea, that nature excludes God, here with a negative religious conclusion, in Herbert Speneer's 'First Principles.' Spencer, as is known, ascended from phenomena to two ultimate categories, a positive one and 
a negative one-the Knowable and the Unknowable. He retained the former exclusively for "science," and left the other exclusively for "religion." Religion was agnostic sentiment that naturally arises in presence of the Unknowable. This sentiment includes what is common to all the religions of the world. It is "undenominational religion," when undenominational religion is treated logically. Spencer called God "Unknowable Power," but without explaining how he came to know enough about Unknowableness to be able to bring it under "Power" or any other category. And he failed to explain how, consistently with this amount of knowledge, he was otherwise ignorant of all about it; this too although he referred to the "Power behind appearances" as "manifested" in the appearances which his synthetic philosophy articulated. Instead of the articles of a synthetic philosophy superseding all knowledge of their ultimate Principle, it seemed to me that (so far as they were true) they all contributed to this linowledge. Without presuppositions of universal or divine reason I could find no sufficient foundation for any synthetic philosophy. This divine synthesis must be its uniting rational principle, uncon- 
sciously assumed, or practically presupposed, by Spencer himself.

I had in like manner come to see in the wellknown three stages which, according to Comte, represent the intellectual progress of mankind, an inversion, instead of an exposition, of historical fact and philosophical reality. According to Comte, it follows from the constitution of mind that man's ultimate conception of the universe must pass through three stages, in its gradual course of evolution towards perfection. At first it must exist in the theological or childish stage, when men refer all phenomena to arbitrary agency, and at this stage all that happens is finally explained either polytheistically or monotheistically; in the next or metaphysical stage, abstract causes supersede arbitrary agency of gods, and the course of nature is explained by referring all events to metaphysical categories or "forces" - mechanical, chemical, and biological-in which Comte sees only empty phrases or formulas:-at last, in the positive or scientific stage, metaphysical abstractions as well as capricious personal agents are ejected, and all that appears or happens in the universe is conceived as exemplifying natural law. Now I 
THEISM, METAPHYSIC, "POSITIVE SCIENCE." 299

asked myself whether this last stage does not necessarily presuppose, and (it may be unwittingly) proceed upon metaphysical categories; and also whether, on the homo mensura, aut nulla mensura principle, those categories must not be vitalised or humanised theistically. Is it not the true office of positive science, not to supersede metaphysical abstractions and their theological correlatives, but on the contrary to strengthen and illuminate both metaphysics and theology? Is not advance in positive knowledge of natural laws truly advance in knowledge of God, the Active Intelligence immanent in nature; who must be presupposed as the uniting Principle or Power, in and through whom positive science becomes credible and intelligible; and who is immediately operative throughout the universal and constant natural evolution? By accepting the homo mensura criterion, the teleological conception becomes man's ultimate conception, to which the cosmological conception must be subordinate, and which it needs.

But is not all this, I might be asked, to assume without proof the teleological or theistic conception, as at the root of experience and science? Is 
not this presupposed theism a transgression of the conditions of legitimate hypothesis, and hospitality offered to an arbitrary, if not absolutely unintelligible, conjecture? Instead of accumulating fresh specimens of apparent design in organised beings, as formerly natural theologians like Paley were wont to do, I was charged with taking for granted the omnipresence and omnipotence of Divine Active Intelligence without this or any proof. Where were the facts on which the stupendous conclusion of theism might be rested? How, without experience to rest upon, could one go behind all experience of the universe, and then pretend to explain the universe?

The fact was that I did not think of Omnipotent and Ommiscient Mind as "a cause," in the way so-called "natural causes" are treated as causes. To think of God as one natural cause among many, would be to think of God as one of many finite persons in nature-the greatest of them, perhajs, but, like the others, Himself needing a natural cause, and this cause needing a predecessor, by which it too had to be conditioned in turn. The infinite ground of the Whole must, I thought, be presupposed; not being provable by induction, yet implied in all induc- 
tion. Moreover, the opposite, or virtually polytheistic conception seemed by implication to be atheistic, as all polytheism is; for a plurality of gods needs final explanation as much as any other plurality of finite persons. A finite god is not God, but is only an individual, in a universe which still requires the presupposition of the Infinite God.

In the narrow meaning of "cause," the causal judgment cannot be applied beyond the limits of physical experience. It does not enable us to penetrate beyond the finite data, empirically presented, of which it is a uniting principle. But causation in the highest sense must be originative, not transmissive only, even if continuously transmissive. When isolated examples of special design, like those collected by Paley, were traced by science, in its progressive interpretation of nature, to natural causes, their theistic meaning disappeared - unless there was sufficicnt reason for postulating design in all that is naturally presented to us in the endless evolution of things and persons; and for postulating the universe as throughout the expression of Active Intelligence. Finite and contingent facts, however numerous, could not, per se, by their merely 
finite evidence, conduct to the infinite and absolute conclusion which theism requires. The incomplete cannot, by itself alone, prove the Absolute.

So it did not seem that the theistic presupposition was necessarily an irrational presupposition. It might even be an assumption imposed by a rational necessity. To take for granted the omnipresence of Active Intelligence in nature, or that omniscient and omnipotent Mind perpetually and universally animates the universe, was an assumption required by reason-if it could be shown that without making this assumption, unconsciously if not consciously, man could not have any science or intelligible experience.

Infer God empirically, from the phenomena presented in sense, and you reason in a circle: presuppose God, and the universe at once becomes interpretable. Unless the universe in which I find myself is a divine cosmos, I camnot treat it, either in my thought or in my conduct, as absolutely trustworthy. I camnot trust in the practical permanence of natural law, upon which all science proceeds. The seeming cosmos, trusted in ordinary human life, may become finally chaotic instead of cosmic-if all must at last be 
RATIONALE OF THEISTIC FAITH AND HOPE. 303

resolved into Unknowableness; and our intelligence and science may dissolve at last in irretrievable confusion. In continuing to live and act, and to interpret any portion of the universe, I must proceed upon the Final Venture-that nature in experience is really the language of God, and that Divine Order is supreme and universal. I must accept this as a Venture, unless I can comprehend the concrete universe in its infinity. But although it is a Venture, yet to refuse this final Venture is unreasonable, if the refusal is (unwittingly) suicide of reason. And the intellectual and moral suicide which this refusal involved formed the reductio ad absurdum by which my presupposition of ultimate Divine Order was vindicated. The universe might become an insane wholly incalculable universe, unless it was the issue of Divine Reason. So theistic faith was the ultimate implicate of all finite experiencean experience finite even when it includes the collective experience of mankind; infinitesimal, when it means only the interpretations of an individual person.

But a presupposition of Active Intelligence, merely as intelligence, was not enough to secure 
escape from universal nescience, or from the possibility of this being an absurd irrational universe, which, in truth, would not be a universe at all. The Supreme Intelligence, merely as such, might be non-moral, or even immoral, in action. So I must postulate Moral Reason, or perfect Goodness-with all that is implied in perfect Goodness - operative at the centre of the universe. Otherwise the Universal Mind revealed in and through my experience, and through collective human experience, may deceive me. I cannot treat experience with the confidence which daily life and science of nature demand. Supreme Intelligence may be diabolic instead of perfectly Good; or may at least operate without purpose, either good or evil, and in the end chaotically. Such a final conception of the Mind universally at work leads to paralysis, intellectual and moral, unless it is arrested by faith in moral Mind. I can no more maintain intercourse with a nonmoral or immoral, and therefore untrustworthy, universe, than I can with a man who is untrustworthy. The universe of fiucts, always under the theistic postulate, must be taken as revelation of ommipotent Goodness. It is true that any individual experience of it is minute 
in degree and extent, and that the collective experience of mankind is only "in part." Let it also be granted that human conceptions, intellectual and moral, are in a process of progressive evolution and improvement. But, on pain of not thinking or acting at all, I must proceed on the moral Venture, that no future "scientific progress" will demonstrate the falsehood of geometry; nor, so far as they go, of the law of gravitation, or the still more comprehensive law of physical evolution. We must also assume that "moral progress" will never demonstrate the duty of lying, or the duty of cruelty. And a knowledge "in part" would be impossible if Perfect Goodness in the infinite Nind was not absolutely presupposed, although particular applications are Ventures. This was not, I thought, movement in the dark, if it was reasonable movement in divine light. The reductio ad absurdum to mental paralysis was the reasoned vindication of a theistic faith that can thus see real knowledge in a progressive knowledge that is always "in part."

So, on the whole, I concluded that the theistic presupposition of omnipotent and omniscient Goodness in the heart of the universe was im- 
plied in the practical reliability of human experience. Trust in the constancy of natural order was ultimately trust in a morally trustworthy, or essentially divine, unirerse; in which man could not at last be inevitably put to intellectual and moral confusion. All inductive faith was essentially and at last ethical and spiritual faith, progressively expanding with human intelligencerationalised more and more articulately in the progressive philosophical development of mankind; but never transcending the final Venture which is our indispensable substitute for Omniscience.

Still, even our narrow experience of the universe presented one obtrusive fact, which seemed to contradict the theistic presupposition of Omnipotent Goodness. The contingently presented universe of experience, which philosophy tries to reduce to rational unity, consists of uneonscious things and self-conscious persons. Things are believed to evolve in natural order, which is thus virtually divine language; and this divine language of things is (so far) scientifically interpretable by persons. But persons themselves - at least on this planet - seem to be naturally evolved in moral disorder, and to live in a chaos of suffering. 
Pain, the supposed consequence of moral disorder, seems to be unfairly distributed. The constant order of insentient things is in striking contrast to the moral disorder that appears among living persons. What ought not to be, is commonly found in them. Analogous irregularity is not seen among things; which are all found punctually obeying their natural, yet supernatural, laws-and they are not expected to involve us at last in intellectual disorder. The material world of things does not put us to final confusion, although most of its phenomena remain uninterpreted, or inadequately interpreted. But the world of persons seems to be continually putting us to moral confusion, by its strangely chaotic appearances. Can this be reconciled with the postulated theistic trust, on which our natural science of things ultimately rests? Can manifested Evil be consistent with the presupposition that Omnipotent Goodness is at the heart of the Whole?

But one hears that persons, indeed all sentient beings collectively, are too insignificant in number and in magnitude to be made any account of, in a universe that is infinite in magnitude and duration. This thought is apt to rise. The seeming contradiction between the theistic pre- 
supposition of omnipotent and omniscient Goodness at the heart of the universe, and the suffering and moral disorder of sentient beings and self-conscious persons on this globe, led me to reflect anew upon the office of persons, in a universe composed of things and persons, and on the mutual relations of Nature and Spirit in the whole economy.

Their office seemed to be important out of all proportion to their visible and tangible magnitude. "Man," as Pascal says, " is indeed only a reed, weakest in nature; but he is a reed that is conscious. It needs not that the whole material universe should arm to crush him. A vapour, a drop of water, is enough for the purpose. Yet even if the whole material universe united to crush him, man would still be more noble than that by which he was destroyed; and this because he knows that he is about to die, while the material universe knows nothing." If physical magnitude were taken as the supreme test, the infinite magnitude of space, and perhaps of its material contents, would no doubt reduce to insignificance the human family upon this little planet, and their moral disorder too. Nevertheless, in a universe which embodies omnipotent 
Goodness, it seemed that even one wicked person reflected as much upon the goodness of the Supreme Mind as innumerable examples; because God is presupposed to be omnipotent, and therefore, if morally perfect, both able and willing to preserve moral order universally; or at least to restore moral order, for the sake of moral order, if disorder should anyhow enter. Each person on the planet is indeed insignificant in respect of the amount of space occupied by his organism, and so too is mankind collectively. Some fifteen hundred millions of human persons are here simultaneously in life. And when all past and all coming generations of men are added, even these may be an infinitesimal minority of the self-conscious agents who have their homes in the innumerable worlds in the starry heaven; perhaps spirits too who are conscious but unbodied. Hence the world of persons, even in magnitude and number and duration, is not so wholly out of proportion to the world of things which science is gradually interpreting.

But the quantity of space they occupy is not the appropriate test of the importance of conscious persons in the universe. The material world, 
with its appallingly incomprehensible magnitudes in space and time, was itself, I reflected, dependent for its actual reality upon the pereipient or conscious persons, and other sentient beings, who are spoken of as its inhabitants. What, I asked, would become of all the things in the universe, if all conscious and pereipient persons were suddenly annihilated? I tried to conceive a wholly material universe, totally emptied of sentient intelligenee and volition, and I found myself face to face with what is inconceivable and unintelligible. The colours, sounds, tastes, smells, solidity, and extent of things disappeared, in this supposed absence of all percipience or living experience. The whole material world at once in consequence dissolved. Although persons emerge from things, men at birth from nature, yet the nature by which they are conditioned, and the natural order according to which they make their appearance, become themselves positively real only in and through the percipient, sentient, and moral experience of living persons, with its implied intellectual and moral presuppositions. Accordingly, under this deeper conception of the unity of the universe, the things of which it consists are all dependent for actuality 
upon the persons that it contains. And it appeared that not on earth only but in the universe there was nothing great but Mind. Was it not also true, I further asked, that the things in the universe exist for the sake of the persons in the universe, not persons for the sake of the things; and that in the whole universe, as far as man is concerned with it, there is nothing independently real except sentient, percipient, and morally endowed beings? If persons in their individualities are of no concern in the abstractions of physical science, they are of supreme concern in all ultimate philosophy. They are real agents: things are only aggregates of significant appearances. The merely natural world consists of passive signs that are made real and interpretable through persons. The moral world presents the wonder of free agents who are able to choose what ought not to be chosen, as well as what ought, and who are therefore morally responsible for their choices.

So I asked whether the existence of persons, able to introduce moral disorder into themselves, was a fact that demonstrably contradicted the idea of a divinely ordered universe, which I had accepted as the necessary postulate of human experience? Was it not possible that 
a universe totally empty of free agents - and therefore of their moral as well as immoral acts, and thus of their disturbing abnormal influencemight be a less divine universe than the mixed universe in which we find ourselves; which contains persons able to do what they ought not to do, and who can introduce suffering as the natural consequence of their sin? If "freedom" to become what one ought not to be, is implied in an individual personality, and in responsible agency; and if a universe that contains moral agents is more worthy of existence than a wholly non-moral one-the temporary existence of sinners and sufferers on our planet, or elsewhere, would even be a consequence of the divinity of the Whole. Omnipotence itself camnot overcome the visible contradiction that is involved in persons being at once free agents and not free agents. Moral agents must be able to originate the acts for which they are responsible, notwithstanding the risks implied in this freedom of their acts from divine natural law;-unless it ean be demonstrated that the universe in which such risk is run must be an undivine universe, simply because it contaius moral ayents upon trial. The presence in it of persons who may 
NATURAL ORDER AND PERSONAL FREEDOM. 313

become what they ought not is otherwise no disproof of theistic optimism. It does not demonstrate that the theistic presupposition, on which life and experience depend, must be untrustworthy. A universe which has room for the probation and education of independent agents may be a better universe than one that consists only of impersonal things, - one containing no agents on trial, or in progressive education of character, through the mixture of joy and sorrow that is found in human experience.

We cannot, in short, at our finite point of view, know enough about the infinite universe of reality to be able to show, that the natural world of significant and scientifically interpretable signs divinely directed, and the world of spiritual agents free (so far) to direct themselves, are conceptions which must be seen by finite intelligence to be absolutely inconsistent. For physical nature, and the mixed moral world must both at last merge in what is incomprehensible or mysterious - at our side-point of view. Mysteries of faith are issues of necessarily incompletable knowledge; they do not necessarily involve contradiction. Omnia exeunt in mysteria is only the consequence of human 
knowledge being incapable of rising into $\mathrm{Om}$ niscience. Omnia exeunt in contradictoria, on the other hand, would be intellectual suicide. The mysteries involved in the boundlessness of space and time, and in natural causation-when space, time, and cause are refunded into infinity, occasion no perplexity either in thought or action, as soon as we recognise that they become contradictions only when we unphilosophically take for granted that Infinity-which transeends quantity and all relations of whole and partscan be dealt with as a Whole. At our side riew-point, time, for instance, seems divisible into a past eternity and a future eternity, cach unlimited; yet the past apparently always increasing in magnitude, and the future always diminishing. This increase and diminution would be true if past and future were finite quantities, instead of being infinite and unquantifiable. Yet notwithstanding this inevitable ultimate mystery, we can regulate our lives by chronological tables and by the clock. Ultimate mysteries in space do not interfere with locomotion. And the final mystery of the cosmological conception does not arrest our scientific interpretation of nature. So too our own crea- 
tive agency, implied in moral freedom, is not necessarily inconsistent with the Omnipotence and Goodness of God. Infinity, which is another name for mysterious reality, remains (for us) at the root of all.

So it seemed that a scientific resolution of the contingent in experience into divine necessity of reason, and resolution of the mixed cosmos of moral experience into perfect divine teleology, were both impossible for man. But this did not satisfy me of their absolute inconsistency, or produce sceptical paralysis, any more than the mysteries into which space and time retire need to lay an arrest upon thought and action in daily life.

The chief human interest of theistic faith, and in its philosophical reasonableness, lies in its relation to the meaning and issues of physical death. Notwithstanding physical death, and notwithstanding the (supposed) fact that all individual persons begin to be, is it true that individual persons can never cease to be? Are persons spiritually non-mortal, although they are physically mortal, and although all merely physical things are subject to dissolution? May 
we reasonably believe in the non-mortality of persons, in spite of the constant disintegration of things, including the bodily organisms of persons themselves?

This is of course a less comprehensive question than the theistic one, which concerns the ultimate guarantce man has in his experience of the universe. Perhaps on this planet the question comcerns only man; but it relates to all self-conscious persons in the universe.

If we could not reasonably believe in the reality eren of this secular life without taking in the theistic presupposition, I suppose that a fortioni we cannot beliere in a posthumous life except in and through the same presupposition. But the practical importance to persons of their theistic faith diminishes infinitely, if their individual personality and consciousness is limited to this evanescent secular life. Man's hold of cxistence on this globe is usually confined within a century, from its beginning at physical birth to its ending in physical death; ennobled as even life on earth may be by conscious moral relation to God during the eranescent interval between birth and death.

So I was ready to ask whether the inevitable 
postulates involved in theistic faith necessarily require that, although individual things are in constant flux, individual persons can never cease to live. Would their death and final unconsciousness contradict the moral character of God, or necessarily imply imperfection in the divine ideal of the universe of reality? Must moral beings, who have once entered into selfconscious existence, retain their self-conscious individuality for ever? Because we each share in the Universal Reason in this embodied state, must we continue individually to participate in it without end? If so, why? We seem to have been sharing it only for a few years at most in the past?

Necessity in reason, which even God could not overcome, did not here appear. Yet I found in books of ecclesiastical theology what seemed to imply, that persons are too important ethically to be permitted finally to disappear, if they have once individually come into morally responsible existence. I could not find that this needed to be presupposed, in the way the theistic presupposition needed to be presupposed-i.e., as the indispensable foundation of the universal order on which the sanity of life depends-nor 
could I see now it was in virtue of this that man was "an image" of God. Faith in immortality seemed to need proof, through facts in the divinely constituted universe. It could not be taken as a universal presupposition, indispensable if we are to have any, even secular, experience. But physical facts, or spiritual facts, or both, might be signs of our continued personality. Were there such signs? I asked; and were they so significant of human immortality that one could say that the universe was putting us to irretrievable intellectual and moral confusion unless we accepted this as their meaning? I could not answer this question affirmatively when I turned to the supposed signs.

In our physically scientific generation I found a disposition to determine the question by ordinary experimental methods of proof, through what is called psychical research. There is evidence, so some say, of social intercourse, maintained through natural signs, between embodied persons now on earth and persons physically dead-just as there is intercourse, through natural signs, among persons all now living embodied on this planet. Some who have died physically, we are told, sometimes signify to persons still living that 
they are alive. I could find no sufficient evidence of this intercommunion, unless the historical record of Christ was an exception; but curiously the leaders of psychical research do not seem to be attracted to investigation of this record, the most remarkable in its historic consequences of all reported instances in the history of the world of intercourse of the living with those who were believed to have died.

But what shall we say of signs in the spirit of man, as these are disclosed when we reflect? What shall we say of our thought that wanders into immensities and eternities, and that concerns itself with the infinite riddle of the universe? Can an individual spirit that is actually, or at least potentially, able for all this live only during the evanescent flash of conscious life that lasts between physical birth and physical death? Is intellectual congruity and sanity in the final working of the universe consistent with an arrangement like this? - It no doubt seemed mysterious, but I was not able to conclude that the arrangement was necessarily undivine. I did not know enough about the universal economy to conclude thus.

Then what of the seeming moral chaos on this 
planet, on which so many persons live wicked lives, and on which so many sentient beings seem to suffer unjustly, or to be inequitably rewarded? Moral distinctions do not appear to be equitably measured during this terrestrial period of existence - yet may it not be true, if God is Omnipotent, perfectly Good, and therefore necessarily bent upon making all persons in the universe perfectly good too-may it not be true that this moral chaos is only a brief interval in the history of persons? And may not the "capricious" distribution of pain and pleasure be a part of their moral and spiritual education? Instead of the appalling gospel attributed to Calvin, of a capricious selection of a few persons to be made goorl, leaving others (or even one person in the universe) to go on increasing in wickedness for ever-may it not be that, after due suffering in another life, proportioned to the history of the life here, all are in the end made spiritually good; or, if not thus, that the free agency and probation in which they lived here may be continued, under increasingly favourable conditions, after physical death,-edueation by future as well as by present suffering-remedial, not revengeful-through all which, under the divine economy, all persons 
are, as their endless lives advance, sooner or later gradually raised out of the life of sense into the divine life of the spirit and moral likeness to God?

I do not know that ecclesiastical authority can produce sufficient reason for extinguishing this hope; or that it can show that the perfect Goodness of God is consistent with any persons who are kept in existence being endlessly and increasingly wicked; or that final elevation of each into goodness is too arduous an achievement for Omnipotent Power. And as to the posthumous life, may we not leave our terrestrial embodiment in theistic faith and hope, departing like the patriarch, when he went out, "not knowing whither he went"; assured at least that we live and die in a universe that must be fundamentally divine, and in which therefore all events, death included, must co-operate for the realisation of divine ideal good to those who seek the good?

Philosophy developed out of theistic faith was thus taken as the true via media between atheism and pantheism. It excluded atheism by the reductio ad absurdum of total Nescience, or intellectual and moral paralysis, which atheism 
involves. It excluded pantheism because the human Omniscience which pantheistic rationalism implies, in like manner, forms its reductio ad absurdum. Atheistic and Pantheistic philosophies were irrational, because the one landed us in the absurdity of human Nescience in a finally irrational universe, and the other in the absurdity of a possible human Omniscience of the infinite universe of reality. Theistic faith gave the reasonable conviction that is found under a knowledge that must be ultimately incomplete. In tenebris semper might be the formula of Atheism; In Luce Divina that of Pantheism: In tenebris Lux was the intermediate formula of Theistic Philosophy.

Among other objections to this via media, I am told that it involves unreasoning dogmatism; that it lays an arbitrary arrest upon reason; that only the rational is real, and that no limit can be imposed on reason.-But surely the arrest is not arbitrary, if it is imposed because reason itself finds something in the final reality which refuses to be interpreted by intelligence in terms of human science. Does not practical reason present facts which, in the name of reason, 
refuse to submit to our theoretical solutions? Also what we call contingency, at our side-point of view, may be seen in perfect rationality, at the divine or central point of view; yet it must in reason remain contingent and empirical to finite intelligence with its narrow'experience. It was thus that a reasonable absolute trust, instead of omniscient intelligence, appeared to be the final philosophical attitude for man. The universe presented to us to be rationalised was a universe in which (for us) "contingencies" intermingle with rational necessities. While our theistic faith implies the divine rationality of what to us appears contingent or mysterious, the faith that all is absolutely the revelation of Divine Active Reason may mean, that the contingencies and mysteries are due to our modest share of this Reason.

It is also alleged that a universe in which persons, who must have power to make themselves good or bad, are superior to things, which have no power at all - a universe in which things exist for the sake of persons, not persons for the sake of things-must be a universe that carries in it the seeds of total incoherence or self-contradictoriness. The will of God is taken 
as the immediate agent in nature, and, accordingly, things only appear to act: God makes moral agents, on the contrary, themselves able to act, righteously or wickedly,-desiring indeed that they should be good, but not forcing them mechanically, and thus depriving them of moral agency. The natural world presents intelligible divine order: the moral world is supposed able to express undivine anarchy. The two are irreconcilables: if free ageney is let in, seientific unity is dissolved.-But does not this objection proceed upon the dogma that the visible order of nature is the final and absolute order; and also that "natural causation" is finally comprehensible in human science, instead of at last resolring into a tissue of ineomprehensibles;-none of them, howerer, necessarily involving visible contradiction? In like manner, in the moral world, the present freedom of persons to make themselves wicked can be comprehended only " in part." The moral world, like the natural, lands us in ultimate incomprehensibilities, which are the bar reason puts against further explanation. With the world of things and the world of persons each incompletely comprehensible, in themselves, and also in their relations 
to each other-is it not presumptuous to assert that their coexistence and ultimate harmony in Divine Reason is an impossibility?

I find it likewise objected that our Theistic Philosophy-with its universe fundamentally a universe of persons in their moral relations, not merely a universe of things in physical relations; in which physical science rests on the moral and religious conception, not the moral and religious on the physical or "scientific"; and this with an implied theistic optimism-is at best only a covert version of the Christian faith. - The implication here seems to be, that conformity of a philosophy with Christianity is its reduction to absurdity, and it is dismissed as only a less articulate expression of the offices of triune and incarnate Deity that has been elaborated in the ecclesiastical theology of Christendom. The objection seems to proceed upon an already mentioned postulate common in Butler's time"That Christianity is not so much as a subject of inquiry; but that it is now at length discovered to be fictitious." However this may be, one cannot resist conclusions to which reason seems to lead; and it is to reason, not to authoritative Christianity, that philosophical appeal 
is made. Indeed if Philosophy and Christianity unite in taking Moral Personality as the supreme human category for interpreting the universe, this goes to vindicate Christianity rather than to refute Theistic Philosophy. It suggests that Coleridge may be right when he speaks of the Christian faith as " reason in its highest form of self-aftirmation," and of Christianity as "the perfection of human intelligence."

An opposite complaint to the last is that the "gospel" of theistic philosophy implies a presumptuous claim for reason; as if it were able to discover that divine love for man is necessarily implied in the omnipotent goodness of God. Divine love - that is to say, divine determination to make persons good who have made themselves bad, because their final wickedness would be inconsistent with divine goodness-is assumed to be a proposition that transcends divine revelation given through reason and experience: it can come to us only through a miraculous historical revelation. When philosophy presupposes the perfect goodness of God, and that divine goodness means power and will to make bad persons now in existence good in the end, through education of suffering, and 
under a gradual evolution - this is condemned as furtive adoption, and even exaggeration, of miraculously revealed truth. It is philosophy stealing without acknowledgment from the gospel of Christ. "As in Adam all die, so in Christ shall all be made alive." As persons in "travailing creation" are able to make themselves bad, so all must in the end be either annihilated or made good, and creation be delivered from the bondage of corruption into the glorious liberty of the sons of God. "Then cometh the end, when $\mathrm{He}$ shall have put down all rule and all authority and power." Natural theology or theistic philosophy, it is assumed, can only see the evil : it cannot even suggest this "gospel," which comes from the arbitrary determination of God, not from necessity of reason divine. Theistic philosophy is alleged to be only a new edition of "Christianity as old as the Creation." - But may not reason and Christianity respond to one another? May not Christianity, in its wonderful historical evolution, with its claim to be the universal religion, and Philosophic Theism with its deductions from its rational implicate of God's perfect love of good, and of divine desire to make all persons good, as the indispensable 
ground of even ordinary trust in the natural and the moral world, harmonise with one another? The more vague gospel of Theistic Philosophy and the articulate gospel of essential Christianity may here respond to one another, each practically confirmed by the response.

My Gifford lectures ended in 1896, and they were published in that year as the 'Philosophy of Theism.'

Events and the course of thought since are too near to be easily seen in true perspective.

A delightful family visit to Holland was a recreation in which we indulged in 1895. I had been attracted by the outlook on Holland as I saw it from the summit of that church-tower in the city of Erasmus in 1842, but for more than half a century I had no opportunity for nearer inspection. In 1895 we made The Hague our headquarters for a time, and explored the country, nearer intimacy adding to the interest. During our stay we had the advantage of the society and direction of Professor 'Tiele of Leyden, my eminent successor in the Gifford lectureship at Edinburgh, of whom Holland was justly 
proud, and who, during his residence in Scotland afterwards, endeared himself to many who now mourn his unexpected death. In visiting him we became at home in Leyden and its famous university, that favourite resort of Scottish students of law and theology in the seventeenth and eighteenth centuries. In Holland I had opportunities for visiting the haunts of Descartes during his seclusion there, in that prolonged meditation which opened a new era in science and philosophy. The humble homes in which Spinoza passed his short self-sacrificing life formed another attraction, as well as the grave in which his ashes lie in the Neue Kirche at The Hague, beneath the pulpit, and beside the tombs of the De Wetts. And I was able to carry further my companionship with Locke, by tracing him in his wanderings, at Amsterdam and elsewhere, during his voluntary exile in Holland, in the five years before the English Revolution. My friend Professor Van der Wyck attracted us to Utrecht; in his absence in Italy, Doctor Beets provided a delightful day in that quaint city and its university. After leaving Holland we ascended the Rhine; but the Rhine after Holland was a disappoint- 
ment. We returned home through Belgium. A long summer day spent on the field of Waterloo, in trying to form a mental picture of the order of the battle and the movements of the armies, was my latest experience of continental Europe.

The 'Philosophy of Theism' was hardly out of the press when I was asked for a biography of Thomas Reid, to form one of the volumes in the "Famous Scots" series. I was glad to be invited to a fresh retrospect of Reid, to whom I had been referred for direction by Cousin forty years before, and whom I was now able to look at in the light of intervening thought. I found him home-bred and self-contained, a sagacious Scot, whose office was, in eighteenthcentury spirit, to encounter philosophical scepticism with dogmatically assumed practical reason. In following his life I examined Reid's appeal to divinely inspired data in what he called the "common sense" of mankind: now seen in the wider light of theistic philosophy, and not merely as inductive philosophy of mind in man. The theistic postulate on which human experience rests could be compared with Reid's 
dogmatic assumption of uncriticised "necessities to believe." A pilgrimage to his birthplace at Strachan, in the secluded valley through which the Feugh finds its way from the Grampians to the Dee at Banchory; a visit to the parish of New Machar, where he found his weapon for war against Hume, not unlike the securus judicat orbis terrarum, which in another interest was the watchword of Newman; a visit to his academic home in King's College at Aberdeen, that miniature Oxford almost under the shadow of the Grampians - collecting biographical material by the way - all formed a pleasant episode in the summer of 1897.

Other days in that summer recall the Isle of Skye, where a week in a family tour was spent in following the footsteps of Charles Edward, from his landing at Mugstock to his departure from Portree, and afterwards on his return from Raasay: I had traced his movements around Loch-na-nuagh and Loch Morar, years before, guided by Sir John and Lady Skelton. I also followed Johnson and Boswell, in Raasay and then in Skye, as they moved from place to place in that October of rain and storm in 1773. Two romantic adventures - that of the Prince and 
that of the London philosopher, - contrasts, yet both apt to touch imagination,-enlivening Scottish annals in the eighteenth centurywere thus brought home by abounding local associations.

The attempt of Charles Edward to upset the House of Hanover by an army of hastily collected Highland tribes, is among the most romantic events in modern history. It is oftener looked at under the light of sentiment and imagination than under the colder light of practical politics and philosophy. Its transitory suceesses are explained by the startling rapidity with which the Adventurer was wafted south on a cloud of Celtic enthusiasm, combined with prevailing indifference to the Hanoverian dynasty in a nation that had not experienced the benignant rule of Queen Victoria and King Edward. Success depended upon uninterrupted rapidity of movement, supported by immediate co-operation in England, and immediate powerful co-operation of France. Uncalculating enthusiasm found itself wanting in these conditions. It was only indulgence in curious speculation to try to forecast the remoter issues, if the conditions had all been favourable, and if the Stuarts had in consequence 
found their way back to the throne. Even as it was, the rising in the ' 45 , commemorated in song, opened a new era in the Scottish Highlands and in Scotland.

A recast of the 'Philosophy of 'Theism' in a new edition was my chief literary employment in 1898. This was followed by the more formidable task of re-editing in an amended form the Collected Works and Life of Berkeley, to take the place of the 1871 edition, now exhausted. Later thought and research had in the interval modified some former opinions, and later opportunities had added to my store of biographical matter. Berkeley's correspondence with Lord Percival, for which I was indebted to the kindness of Lord Egmont, and his correspondence with Samuel Johnson of New England, to which I was assisted by Dr Beardsley, had cast some fresh light upon his personality and his philosophy.

Some weeks in most of those years of retirement at Hawthornden have been spent in the Land of Lorne, the home of my youth. I returned in old age to scenes, familiar in the morning of life, when inquiry was beginning to 
more uneducated common-sense; but I returned unknown and a stranger, after the lapse of two generations. The railway, the motor-car, and the voice of the tourist now disturb the silence of the unchanged hills. The perplexing doubts about the universe, in which I newly found myself in youth, have led to deeper faith in the immanent Divine Spirit, transforming death from a movement in the dark into a movement in Omnipotent Goodness; trusted when it withdraws us from this embodied life, still unable to picture what lies in the future. "It is not yet made manifest what we shall be." And a philosophical pilgrimage in this life seemed to return upon itself, but to an old world presented in a new light. "You see, Hylas, the water in yonder fountain, how it is foreed upwards, in a round column, to a certain height; at which it breaks, and falls back into the basin from which it arose, its ascent as well as descent proceeding from the same uniform law of gravitation. Just so the same principles which, at first riew, lead to Scepticism, pursued to a certain point, bring men back to Common Sense." The world of sense seen in childhood was transformed in old age for one about to leave it. It was 
connection rather than contrast. It was connection that resembles " the subtle progress by which, both in the natural and moral world, qualities pass insensibly into their contraries, and things revolve upon each other. As in sailing upon the orb of this planet, a voyage towards the regions where the sun sets conducts us gradually to the quarter where we have been accustomed to behold it come forth at its rising; and in like manner, a voyage towards the east, the birthplace in our imagination of the morning, leads finally to the quarter where the sun is last seen when he departs from our eyes;--so the contemplative soul, travelling in the direction of mortality, advances to the country of Everlasting Life; and in like manner may continue to explore those cheerful tracts, at intervals brought back, for her advantage and benefit, to the land of transitory things, of sorrow and tears." 
PRINTED BY WILLIAM BLACKWOOD AND SOAS. 


\section{Cataĺogue}

of

Messrs Blackwood \& Sons

Publications 


\section{PERIODS OF EUROPEAN LITERATURE: A Complete and}

Continuous Histoky of thr SUBJBCt. Edited by Progrsoor SAINTS. BURY, In 12 crown 8 vo vols., each 5s, net.

I. THE DARK AGES. By Professor W. P. KkR.

II. THE FLOURISHING OF ROMANCE AND THE RISE OF ALLEGORY. (12TH AND 13TH CENTURIES.) BY QEORGE SAINTS. BURY, M.A., Hon. LL.D., Aberdeen, Professor of Rhetorio and English Litersture in Edinburgh University.

III. THE FOURTEENTH CENTURY. By F. J. SNBLI.

IV. THE TRANSITION PERIOD. By Prof. G. Gregory SMITh.

V. THE EARLIER RENAISSANC'E. By Thr EDITOR.

VI. THE LATER RENAISSANCE. BY DAVID HANNAY.

VII. 'THE FIRST HALF OF THE SEVENTEENTH CEN'TURY. By Prof. H. J. C. Griersos.

VIII. THE AUGUSTAN AGES. By OLIVRR Elton.

IX. THE MID-EIGHTEENTH CENTURY. By J, H. Millar.

X. THE ROMANTIC REVOL'T. By Prof. C. E. Talghas.

XI. THE ROMANTIC TRIUMPE. BY T. S. OMOND

XII. THE LATER NINETEENTH CENTURY. By The Editor.

\section{PHILOSOPHICAL CLASSICS FOR ENGLISH READERS.}

Edited by WILLIAM KNIGHT, LL.D., Professor of Ioral Philosophy in the University of St Andrews. Re-issue in Shilling Volumes net.

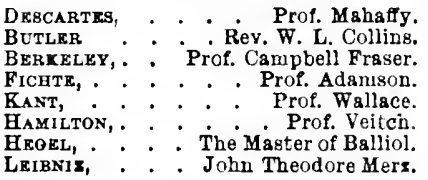

Vico, . . . . . . prot. Flint. HoвBEs, . . Prof. Croom Robertson, HEME, . . . . . . Prot. Enight. Spinora $:$. $_{*} \cdot$ Principal Caird. BaCON: Part I.,. . . . Prof. Nichol. Bacon: Part II., . . . Prof. Nichol LockE, . . . Prố. Campbell Fraser.

FOREIGN CLASSICS FOR ENGLISH READERS. Edited by Mrs OLIPHANT. Chrap RE-ISSUE, In limp cloth, feap, 8vo, price is. each net.

Dante, by the Editor. - Voltairk, by General Sir E. B. Hamley, B.C.B. - Pascal, by Principal Tulloch. - PE. TRARCE, by Henry Reeve, C.B.-GOETHE, by A. Hayward, Q.C.-Molteke, by the Editor and F. Tarver, M.A.-MontaloNF, by Rev. W. L. Collins. - RABELAis, by Sir Walter Besant. - CALDERON, by E. J. Hasell.-8AINT Bimon, by C. W. Collins.
Cervantz8, by the Editor. - Corneille AND Racine, by Henry M. Trollope.MAdaMe DE SÉvigné, by Migs Thackeray. - La Fontaixe, ani other Prench FabUlists, by Rer. W. Lucaz Collins, M.A. - Schiller, by James Sime, M.A. - TAsso, by E. J. Hasell. - Rotsseat, by Henry Grey Graham. - AlFRED Dr: Messet, by C. F. Oliphant.

\section{ANCIENT CLASSICS FOR ENGLISH READERS. Edited by} the Rev. W. LUCAS COLLINS, M.A. Chrag Re-issuk. In limp elotb, fcap. 8vo, price 1s. each net.

Contents of the Series.-HOMEK: ILIAD, by the Editor.-HoMer: ODYssey, by the Editor- - Herodotus, by G. C. Bwinge.Cesar, by Anthony Trollope. - Tikald, by the Editor. - HoRAce, by Sir Theodore Martin.-Aschylus, by Bishop Copleston. -Xenorhon, by Sir Alex. Grent - Cikno, by the Editor. - SOPHOCL as, by C. W. Col. lins.-PLINY, by Rov. A. Chureh and W.J. Brodribb.-Euripides, hy W. B. Donne.J JveNaL, by E. Walford. - ARIBTOPIANRs, by the Editor.-Hesiod aND THEOONis, by
J. Davies. - Platigur and Terence. by the Editor - Tucirus, by W. B. Donne.Leciax, hy the Editur.-Plato, by C. W. Collins, - Greek Axthologr, by Lord Nesves.-Livy, ly the Eritor.-Ovid, by Rev. A. Church. - Catelitg, Tibelle's, AND PropkRTIU, hy J Dsvies -Demos. THeAes, by W. J. Brodribb.-ARistotLE, by Sir Alex. Grsit. - Thucydids, by the Filitor.-Lucretius, by W. H. Mallock.PINDAR, by RA. F. D. Morler. 


\section{OA T A L O G U E}

or

\section{MESSBS BLACKWOOD \& SONS}

\section{$P U B L I C A T I O N S$}

ACTA SANCTORUM HIBERNIE; Ex Codice Salmanticensi. Nunc primum integre edita opera Caroli DE SMEDT et Josephi DE BaCrer, $\theta$ Soc. Jesu, Hagiographoram Bollandianoram; Auctore et Sumptas Largiente Joanna Patricio Marchionk Bothak. In One handsome 4 to Volnme, bound in half rorburghe, $£ 2,28$; in paper cover, 318 . 6 d.

ADAMSON.

The Development of Modern Philosophy. With other Lectures and Essays. By RoBERT ADAMsos, LL.D., late Professor of Iogje in the University of Glasgow. Edited by Professor W. R. SoRLEY, University of Cambridge. In 2 vols. demy 8 vo, 18s. net.

The Development of Greek Philosophy. Eaited by Professor Sorley and R. P. Hardie, M.A. Demy svo, 10s. 6d. net.

AIKMAN.

Manures and the Principles of Manuring. By C. M. Alkmax, D.Sc., F.R.8.E., \&c., formerly Professor of Ohemistry, Glssgon Veterinsry Oollege, and Exsminer in Chemistry, University of Glssgow, dc. Second Impression. Crown 8vo, 68 6d.

Farmyard Manure: Its Nature, Composition, and Treatment. Orown 8vo, 18. 6d.

\section{ALISON.}

History of Enrope. By Sir Archibald Alison, Bart., D.C.L.

1. From the Commencement of the French Revolution to the Battle of Waterloo.

LiBRARY EDDition, 14 vols., with Portralts. Demy 870, £10, 106.

ANOTHER EDITION, in 20 vols. crown $8 \mathrm{vo}$ \&6.

Phople's EDItion. 13 vols, crown 880, £2, 118

2. Continuation to the Accession of Louis Napoleon.

LIBRART EDITION, 8 rols. 8v0, £6, 78. 6 d.

Prople's EDITION, 8 vols, crown 8 vo 348 .

Epitome of Alizon's History of Europe. Thirtieth Thousand, 78. 6d.

Atlas to Aligon's History of Europe. By A. Keith Johnston. LiBRARY EDITION, demy 4 to, £3, 38 .

PROPLR's EDITION, 318. 6d.

ANCIENT CLASSICS FOR ENGLISH READERS. Edited by Rev. W. LUCA8 Colning, M.A. Price 18. esch net. For List of Vols. see p. 2. ARMYTAGE. Maids of Honour. By A. J. Greer-Arnytage. Crown Svo, 10s. 6d. net.

ATKINSON. Local Government in Scotland. By MaBeL ATKINSON, M.A. In 1 vol. demy 8vo, 5s. net. 


\section{AYTOUN.}

Lays of the Scottish Cavaliers, and other Poems. By W. Hidmondstouna A rtoun, D.C.L., Professor of Rhetoric snd Belles-Lettres in the Universitg of Edinbargh. New Hedition. Pcap. 8vo, 8a. od. ChaA EDition. 1s. Cloth, 18. 3d.

An Illustrated Edition of the Lays of the Scottish Cavaliers From designs by Bir Norl Patow. Chesper Edition. Bmall 4to, 10s. 6d.

BADEN - POWELL. Ballooning as a Sport. By Major B. BADEN-Powell. With lllustrations. Crown 8vo, 3s. 6d. net.

BARBOUR. Thoughts from the Writings of R. W. BarBour. Pott 8vo, limp lesther, 28. 6d. net.

"BARFLEUR" Naval Policy. A Plea for the Study of War. By "Barfleur." Demy 8vo, 2s. 6d. net.

\section{BARRINGTON.}

The King's Fool. By Michael Barringtow. Crown 8vo, 6s.

The Reminiscences of Sir Barrington Beaumont, Bart. A Novel. Crown 8vo, 6s.

\section{BARTLETT.}

The Siege and Capitulation of Port Arthur. Second Impression. By E. AshMiead Bartlett. Demy 8vo, 21s, net.

Richard Langhorne: The Story of a Socialist. Crown 8vo, 6s.

BELLESHEIM. History of the Catholic Church of Scotland. From the Introduction of Christianity to tha Present Day. By AIPHONs BEL. Lesheim, D.D., Canon of Alr-la-Chspelle. Trsnslsted, with Notes and Addltions, by D. Ogwald Hunter Blair, O.S.B., Monk of Fort Angratus. Oheap Edition. Complate in 4 vols. damy 8vo, with Mspr. Prico 218. net.

BLACK. The Scots Churches in England. By Kexwetr HaCleod Black. Crown 8 vo, 5s. net.

\section{BLACKBURN.}

A Burgher Quixote. By Douglas BlackBdrN, Author of 'Priusioo of Prinsloosdorp.' Second Impression. With Frontispiece. Crown $8 v 0,6 s$.

Richard Hartley : Prospector. Crown 8vo, 6s.

\section{BLACKWOOD.}

Annals of a Pablishing House. William Blackwood and his Sons; Their Magazine and Friends. By Mrs Oliphant. With Four Portraits. Third Edition. Demy 8vo. Vols. I. and II. E2, 28.

Annals of a Publishing House. Vol. III. John Blackwood. By his Daughter Mrs Blackwood Porter. With 2 Portraits sndView of Strath. tyrum. Demy 8vo, 218.

Blackwood's Magazine, from Commencement in 1817 to June 190s. Nos. 1 to 1112 , forming 153 Volumes.

Tales from Blackwond. First Series. Price One Shilling each in Paper Cover. Eold separstely at all Railway Bookstalls.

They may also be had bound in 12 vols., cloth, 188. Half ealf, richly gilt, 306. Or the 12 vols. in R. rnehnruha. 21a. half red morncen, 288.

Tales from Blackwood. Second Series. Complete in Twenty. four Bhilling Parts. Handsomely bound in 12 volr, cloth, 30s. in lesther back. roxburghe style, 378. 6d. Half caif, gilt, $528.6 \mathrm{~d}$. Half morseo, 558. 


\section{BLACKWOOD.}

Tales from Blackwood. Third Series. Complete in Twelve Shilling Parts. Handsomely bound in 6 vols., cloth, 158.; snd in 12 vols. cloth, 183. The 6 vols. in roxburghe 218. Half cali, 258. Hsilf morocco, 288.

Travel, Adventare, and Sport. From 'Black wood's Magazine. Unlform with 'Tales from Blackwoad.' In Twelve Parts, eseh price 18. Hand80 mely bound in 6 vols., cloth, 158 . And in half cale, 25a.

New Educational Series. See senarate Educational Catalogue.

New Uniform Series of Novels (Copyright).

Crown 8ro, cloth. Price 3s. 6d. esch. Now reads:-

WENDRRHoLMe. By P. G. Hamerton. MARMORne. By P. G. Hamerton.

The Stort of Margrépl. By D. Storrar Reata. By E. D. Gerard.

Meldrum.

Miss Marjorizanza. By Mrs Ollphang.

The Perpetual OURatz, and Thr Rzctog By the Same.

galem Chapel, and Thz Doctor's Family. By the Same.

a Sensitive Playt. Bg E. D. Getara.

LADY Lez's WIDOFHOOD. By Geners] Sir E. B. Hamley.

Batie STEWAHT, and other Storlez. By Mrs Oiiphsint.

VALENTINR AND GIB BROTHRE. By the Same. JONg AND DAUGHTRR. By the Same.

Blgaar my Neiahbour. By the Ssmo.

Thr Wa TER OF Harcules. By the Same.

FAIR TO BEE. By L. W. M. Lockhart.

Mine 18 Thine. By the Bame.

DOUBLES AND QUITS. By the Same.

Altiora Peto. By Laurence Oliphant.

Piccadility. By the Same. With Illuatra. tions.

LADY BABY. By D. Gersrd.

THz BlacksMith OF Vor. By Paal Cashing. My TRIVIAL Life aND Migmortune. By A Plain Woman.

Poor Nellir. By the Bame.

\section{Standard Novels. Uniform in gize and binding. Each compiete in one Polume.}

PLORIN SERIES, Illastrated Bosrds. Bound In Cloth, 29. 6d.

TOM ORINGLE's Loo. By bilcharl Scctt.

The Cruise of the Midor. By the Same.

Cyril Thornton. By Captain tamilton.

ANNALa OF THE PARISH. By John Galt.

IH Provost, \&c By the Sare.

Sir ANDrew Wrila. By the Bame

The Exwail. By the Bame.

Miss Moliy. By Beatrlce May Buty.

izmainald Dalton. By J. G. Lockhare
PrN OKKN, By Desn Hook.

ADAM BLAiR. By J. G. Lockhart.

LADY LRK'Y WIDOWHOOD. By General Blr R. B. Hamley.

8alem Chapel. By Mrg Oíplisnt.

Thr Prrpeteal Curate. By the Ssmo.

Miss Maruoribanes. By the Game.

Jorn: A Love Story. By the Bame.

SHILLING SERIES, Illustrated Cover. Bound in Cloth, 18. 6d.

The Rector, and The Doctor's Family, Sir Prizele Pempin, Niahts at Mess, By Mrs Oliphant. ic.

The Life of Mangir Wadcz. By D. M. The 8ubalteri. Moir

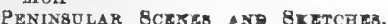
P. Hardman.

LiFE 1.N THR FAR Frgt. By G. F. Rurton. Lockhart.

BON GAULTIER'S BOOK OF BALLADS. A new Edition, with Autobiographical Introduction by Sir THEODORE MARTIx, K.C.B. With Illnstrations by Doyle, Leoch, snd Crowqull.. Small quarto, $5 \mathrm{~s}$. net.

BOWHILL. Questions and Answers in the Theory and Practice of Milltary Topography. By Major J. H. Bowhill. Crown 8vo, 4a. 6d. net. Portiolio containing 34 working plans and disgrams, 38. $6 \mathrm{~d}$. net.

BREADALBANE. The High Tops of Black Mount. By ThE MARChioness of BreadalbaNe, Second Injuression. With Illustrations from Photographs by Olive Mackenzie. Short demy, 6s. net. 
BRUCE. In the Footsteps of Marco Polo. Being the Account of a Journey Overland from Simla to Pekin. By Major Clarexce DalarMple BRUCE. With Illustrations. Demy 8vo, 2Is. net.

\section{BUCHAN.}

The Watcher by the Threshold, and other Tales. By JoHs Buchas. Second Impression. Crown 8vo, 68 .

A Lodge in the Wilderness. Second Impression. Short demy 8 ro, 6s.

\section{BURBIDGE.}

Domestic Floricultare, Window Gardening, and Floral Decoratione. Being Practical Directions for the Propagation, Culture, and Arrangement of Plants and Flowers as Domestic Ornamenta. By F. W. Burbidgr. Becond Edition. Crown 8vo, with numerous Illastrations, 7s. 6d.

\section{BURTON.}

The History of Scotiand: From Agricola's Invasion to the Extinction of the last Jacobite Inanrrectlon. By JOHN HiLL BURTON, D.C.L., Hlatoriographer-Royal for Scotland Chesper Edition. In 8 vols. Crown 8vo, 2s. 5d. net each. Being issued in Monthly volumes.

The Book-Hunter. A New Edition, with specially designed Title-page and Cover by Joseph Brows. Printed on sntique laid paper. Post $8 v 0,38.6 \mathrm{~d}$.

The Scot Abroad. Uniform with 'The Book-Hunter.' Post 8vo, 3s. 6 d.

\section{BUTE.}

The Roman Breviary: Reforned by Order of the Holy Ecumenical Council of Trent; Published by Order of Pope St Pins V.; and Revised by Clement VIII. and Urban VIII.; together with the Offices since granted. Translated out of Latin into English by JoHs, MARqLess of BCTE, K.T. New Edition, Revised and Enlarged. In 4 vols. crown Svo, and in I vol. crown 4to.

[In the press.

The Altus of St Columba. With a Prose Paraphrase and Notes By JohN, MARQUess or BUTE, K.T. In paper cover, 28. 6d.

Sermones, Fratris Adæ, Ordinis Præmonstratensis, \&c. Twenty-eight Diseonrses of Adam Scotus of Whithorn, hitherto unpublished; to which is added a Collection of Notes by the same, illustrative of the rule of St Augustine. Edited, st the desire of the late.Marqurss of BUTE, K.T., LL.D., \&c., hy WALTER DE GRAY BiRCI, LL.D., F.S.A., of the British Museum, \&c. Royal 8vo, 25a. net.

Catalogue of a Collection of Original MSS. formerly belonging to the Holy Office of the Inquisition in the Canary Islands. Prepared under the direction of the late Marquess of Bute, K.T., LL.D., by Walter De Grat BiRCi, LI.D., F.S.A. 2 vols, royal Svo, £3, 3s. net.

BUTE, MACPHAIL, AND LONSDALE. The Arms of the Royal and Parliamentary Burghs of Scotland. By JoHN, Marquess op BuTz, K.T., J. R. N. MaCPHAIL, and H. W. Lonsdale. With 131 Engravinga on wood, and il other Illngtrations. Crown 4to. £2, 28. net. 
BUTE, STEVENSON, AND LONSDALE. The Arms of the Baronial and Police Burghs of Scotland. By JoHs, MARquess or Butr, K.T., J. H. Strvenson, and H. W. Lonsdalev. With numerous Illustrations. Crown 4 to, £2, 2s. net.

CAIRD. Sermons. By SoHN CAIrd, D.D., Principal of the University of Glasgow. Beventeenth Thonsand. Fcap. 8vo, 5s.

CALDWELL. Schopenhauer's System in its Philosophical Significance (the Shaw Fellowship Lectures, 1893). By Professor William CaLd. WELL, D.Sc., $\mathbf{I}^{\circ}$ Gill University, Montreal. Demy 8vo, 10s. 6d. net.

\section{CALLWELL.}

The Effect of Maritime Command on Land Campaigns since Waterloo. By Col. C. E. Callwell, C.B. With Plans. Post 8vo, 68. net.

Tactics of To-day. Sixth Impression. Crown 8vo, 2s. 6d. net.

Military Operations and Maritime Preponderance: Their Relations and Interdependence. Deniny $8 \mathrm{vo}$, 15s. net.

The Tactics of Home Defence. Crown 8vo, 3s. 6d. net.

\section{CAREY.}

Monsieur Martin: A Romance of the Great Northern War. By WyMGNu Carev. Crown 8vo, 68.

"No. 101." Third Impression. Crown 8vo, 6s. Cheap Edition, royal svo, laper covers, $6 \mathrm{~d}$.

CARLYLE. A History of Mediæval Political Theory in the West. By R. W. Carlyle, C.I.E., Balliol College, Oxford; and A. J. Carlyle, M.A., Chaplain and Lecturer (late Fellow) of University College, Oxford. In 3 vols. deniy svo. Vol. I.-A History of Political Theory from the Roman Lawyers of the Second Century to the Political Writers of the Ninth. By A. J. CarlyLE. 15s. net.

CHESNEY. The Dilemma. By General Sir George Chesney, K.C.B. A New Edition. Crown 8vo, 2s.

CHRISTIE. The Influence of Letters on the Scottish Reformation. By Rev. Georaf Cilristis, L.D. Crown svo, 6s. net.

\section{CHURCH SERVICE SOCIETY.}

A Book of Common Order: being Forms of Worship issued by the Church Bervice Society. Seventh Sdition, caretnlly revised. In 1 vol. crown 8vo, cloth, 38. 6d.; French moroceo, bs. Also in 2 vols. crown 8vo, cloth, 48. ; French moroceo, 6s. 6d.

Daily Oftices for Morning and Evening Prayer throughout the Week. Crown svo, 3s. $8 \mathrm{~d}$.

Order of Divine Service for Children. Issued by the Church bervice society. With Scottigh Hymal. Cloth, sd. 


\section{CLIFFORD.}

Sally : A Study ; and other Tales of the Outskirts. By HoGH CLIFroRd, O.M.G. Crown 8vo, 6s.

Bush-Whacking, and other Sketches. Second Impression. Crown 8 vo, 68 .

CLODD. Thomas Henry Huxley. "Modern English Writers." By Kdward Glodd. Crown 8vo, 2s. 6 d.

\section{CLOUSTON.}

The Lunatic at Large. By J. Storer Clouston. Ninth Impression. Crown 8vo, 6s. Cheap Edition, royal 8vo, paper cover, 6d.

Count Bunker: Being a Sequel to 'The Lunatic at Large.' Third Impression. Crown 8vo, 6s. Cheap Editios, royal svo, papers covers, $6 \mathrm{~d}$.

The Adventures of M. D'Haricot. Third Impression. Crown 8vo, 68. Cheap Edition, royal 8vo, paper cover, $6 \mathrm{~d}$.

Our Lady's Inn. Crown 8vo, 6s.

Garmiscath. Crown 8vo, 6s.

CONRAD.

Lord Jim. A Tale. By Joseph Conrad, Author of 'The Nigger of the Narcissus,' 'An Outcast of the Islands,' 'Tales of Unrest,' \&c. Becond Impression. Crown 8vo, 68 .

Youth: A Narrative; and Two other Stories. Second Impression. Crown 8 vo, 68 .

COOPER. Liturgy of 1637, commonly called Laud's Liturgy. Edited by the Rev. Professor Cooper, D.D., Glasgow. Crown 8vo, 7s. 6d. net.

CORNFORD. R. L. Stevenson. "Mlodern English Writers." By L. Cope Cornford. Second Edition. Crown 8vo, 28. 6 d.

COUNTY HISTORIES OF SCOTLAND. In demy 8vo volnmes of about 350 pp. esch. With Maps. Price 7s. 6d. net.

Fife and Kinross. By Enkas J. G. MACKAy, LL.D., Sheriff of these Counties.

Dumfries and Galloway. By Sir Herbert Maxwell, Bart., M.P. Second Edition.

Moray and Nairn. By Charleg Rampini, LL.D., Sheriff of Dumfries and Aalloway.

Inverness. By J. Cameron LeFs, D.D.

Roxbargh, Selkirk, and Peebles. By Sir Georgr Douglas,

Aberdeen and Banff. By WrumaM WaTt, Editor of Aberdeen 'Daily Free Press.'

Perth and Clackmannan. By John Chisholm, M.A., Advocate.

CRAIK. A Century of Scottish History. From the Days before the ' 45 to those within living Memory. By Sir HeNry Craik, K.C.B., M.A. (Oxon.), Hon. LL.D. (Glasgow). 2 vols. demy 8vo, 30s, net. 
CRAWFORD. Saracinesca. By F. Marion Crawford, Aathor of 'Mr Isases,' \&c., \&c. Crown 8vo, 3s. 6d. Also at 6d.

CROSS.

Impressions of Dante and of the New World. By J. W. Cross.

The Rake's Progress in Finance. Crown 8vo, 2s. net.

CUMMING. Memories. By C. F. Gordon Comming. Demy 8vo. Mlus-

At Home in Fiji. Post 8vo. Illustrated. Cheap Edition, 6s.

A Lady's Cruise in a French Man-of-War. Post 8vo. Illustrated. Cheap Edition. Bs.

Fire-Fountains. 2 vols. post 8 vo. Illustrated, $25 \mathrm{~s}$.

Granite Crags. Post 8vo. Illustrated. Cheap Edition. 6s.

Wanderings in China. Small post 8vo. Cheap Edition. 6s.

DAVIS. "When Half-Gods Go." By Jessie Ainsworth Davis. Second Inpression. Crown 8vo, 6s.

DE HAVEN. The Scarlet Cloak. By Addrey de Haven. Crown svo, 6 s.

DESCARTES. The Method, Meditations, and Principles of Philosoyny of Deseartes. Transiated from the original French and Latin. With a new Introduetory Essay, Historical and Critical, on the Cartesian Pliiosophy, By Professor Veitce, LL.D. Fourteenth Edition. Crown 8ro, 6s. 6d.

DIVER. Captain Desmond, V.C. By Madd Diver. Sixth Impression.
Crown 8vo, 6s.

The Great Amulet. Second Impression. Crown 8vo, 6s.

DODDS AND MACPHERSON. The Licensing Acts (Scotland) Consolidation and Amendment Aet, 1903. Annotated by Mr J. M. DodDs, C. B., of the Seottish Office; Joint-Editor of the 'Parish Couneil Guide for Scotland,' and Ifr Ewan Macpherson, Advoeate, Legal Secretary to the Lord Advocate. In 1 vol. erown $8 v 0,58$. net.

DOUGLAS.

The Ethics of John Stuart Mill. By Charles Dodglas, M.A., D.Sc., late Lecturer in Moral Philosophy, and Asststant to the Pro. fessor of Moral Philosophy in the University of Edinburgh. Post 8vo, 68. net.

John Stuart Mill : A Study of his Philosophy. Crown 8vo, 48. 6d. not.

\section{ECCOTT.}

Fortune's Castaway. By W. J. Eccotr. Crown 8vo, 6s.

His Indolence of Arras. Crown 8vo, 6s.

Hearth of Hutton. Crown 8vo, 6s.

The Red Neighbour. Crown 8vo, 6s. 
ELIOT.

The New Popular Edition of George Eliot's Works, with Photogravure Frontispiece to eaeh Volume, from Drawings by William Hatherell, R.I., Edgar Bundy, R.I., Byam Shaw, R.I., A. A. Van Anrooy, Mauriee Greitfenhasen, Claucle A. Shepperson, R.I., E. J. Sullivan, and Max Cowper. Each Work complete in One Volume. Handsomely bound, gilt top. $3 \mathrm{~s}, 6$ d. net. Ten Volumes in all.

ADAM BEDE.

Scenes of Clerical life.

THE Mill oX the Floss.

Felix Holt, the Radical.

Middlejarch.

Essiys; Theophrastus Scch. LIFTED VEIL.

ROMOLA.

DANIEL DERONDA.

Silas Marxer; Brother Jacob; The

The Spayeh Gypsy; Jubal.

George Eliot's Life. With Portrait and other Illastrations. New Edition, in one volume. Crown 8vo, 78. 6d.

Life and Works of George Eliot (Warwick Edition). 14 volumes, cloth, limp, gilt top, 2 s. net per volume; leather, limp, gilt top, $2 \mathrm{~s}$. $6 \mathrm{~d}$. net per volume: leather gilt top, with book-marker. 3 s. net per yolume.

ADAM BEDE. 826 pp.

THE MILL ON THE Floss. $828 \mathrm{pp.}$

Fris Holt, the Radical. 718 pp.

ROMOLA. 900 pp.

Scenes of Clerical Life. 624 pp.

Silas Marner; Brother Jacor; The

LIFTED VEIL. 560 pp.

Works of George Eliot (Standard Edition). 21 volames, crown 8vo. In buckrsm cioth, gilt top, 28. 6d. per vol.; or in roxburghe hinding, 38. $6 \mathrm{~d}$. per vol.

ADAM BeDE. 2 vols, The IILL ON THE Floss. 2 volg. -FeLix HoLt, THE Radical. 2 vols. - Romoi.a. 2 vols. - SCEnes of Clerical Lifk. 2 vols. Middemarch. 3 pols.-Danizl Deronda. 3 volg. Silas Makner. I vol. -J Jbal. I vol. -'Ter Spanish Gypgy, I vol. Essays. I vol.-Throparas. TUB SCCE. 1 vol.

Life and Works of Uteorge Eliot (Cabinet Edition). 24 volumes, crown svo, price $\mathbf{E} 6$. Also to be hsd hsudsomely bonnd in hal? and tal. eslf. The Voinmes sre sold separstely, boand in cloth, price 5s. esch.

Novels by George Eliot. Popular Copyright Edition. In new uniform linding, price $3 \mathrm{~s}$. bd. each. ADAM BEDE.

THE MILL ON THE Floss.

Scenes of Clerical Like.

Rosiola.

Feitix Holt, the Radical.

Silas Marier; The lifted Veil; BROTHER JACOB.

Middiemarch.

DANiEL Deronda.

Essays. New Edition. Crown ơvo, b́.

Jmpressions of Theophrastue Such. New Edition. Crows $8 \mathrm{vo}, 5 \mathrm{~s}$.

The Spanish Gypsy. New Edition. Crown 8vo, 58.

The Legerd of Jalal, and other Poems, Old and New. New Euition. Crewu 8vo, ss.

Silas Marner. New Edition, with lllustrations by Reginald Bireh. Crown 8vo, 1s. bid. net. Cheap' Edition, 2s. 6d. Cheap Edition, royal svo, paper cover, price bid.

Scenme of Clerical Life. Cheap Enlition, 3s. Illustrated Edition, with ze mllustrations by H. R. Millar, erown 8ro, 2s.; paper covers, 28. Cheial, Edition, royal $x$ vo, in pusper cover, price bd

Felix Holt. Cheap Edition. Royal 8vo, in paper cover, 6d. 
ELIOT.

Adam Bede. Cheap Edition, royal 8vo, in paper cover, price 6d. New Edition, crown 8vo, paper cover, 18.; crown 8vo, with Illnstrations, cloth. 2a

The Mill on the Floss. Cheap Edition, royal 8vo, in paper cover, price $6 \mathrm{~d}$. New Edition, paper covers, 1s.; eloth, $2 \mathrm{~s}$.

Wise, Witty, and Tender Sayings, in Prose and Verse. Selected from the Works of GkORGE ELIOT. New Editlon. Fcap. 8vo, 3s. 6d.

ELLIS.

Barbara Winslow, Rebel. By Beth Eulis. Crown 8vo, 6s. Madame, Will You Walk? Crown 8vo, 6s.

Blind Mouths. Crown 8vo, 6s.

The Moon of Bath. Fourth Impression. Crown 8vo, 6s.

ELTON. The Augustan Ages. "Periods of European Litera. tare." By Otiver Elton, M.A., Professor of English Literature, University College, Liverpool. Crown 8vo, 5s. net.

EVERARD. History of the Royal and Ancient Golf Club, St Andrews. By H. S. C. Everard. With Eight Coloured Portraits, and many other Unique Illustrations. Crown 4to, 21s. net.

FAHIE. A History of Wireless Telegraphy. Including some Bare-wire Proposals for Subaqueous Telegrapns. By J. J. FA Institution of Electrical Engineers, London, and of the Société Internationale des Electriciens, Paris; Author of 'A History of Electric Telegraphy to the Year 1837,' \&c. With Illustrations. Third Edition, Revised. Crown 8vo, 88.

FERGUSSON. Scots Poems. By Robert Fergusson. With Photogravure Portrait. Pott 8 vo, gilt top, bound in cloth, 18. net; leather, 1s. 6 d. net.

FERRIER. Philosophical Remains. Crown 8vo, 14s.

FLINT.

Philosophy as Scientia Scientiarum. A History of Classifications of the Sciences. By RoBkRT FliNt, D.D., LL.D., Corresponding Member of the Institute of France, Hon. Member of the Royal Soclety of Palermo, Professor in thin University of Edinburgh, \&c. 12s. 6d. net.

Studies on Theological, Biblical, and other Subjects. 7s. 6d. net. Historical Philosophy in France and French Belgium and Switzerland. 8v0, 218.

Theism. Being the Baird Lectare for 1878. Tenth Edition, Revised. Crown 8vo, 7s. 6d.

Anti-Theistic Theories. Being the Baird Lectare for 1877. Fifth Edition. Crown 8vo, 108. 6d.

Sermons and Addresses. Demy 8vo, 7s. 6d

FOREIGN CLASSICS FOR ENGLISH READERS. Edited by Mrs Olipeant. Price 18. each net. For List of Volumes, see page 2.

FORREST.

History of the Indian Mutiny. By G. W. Forresr, C.I.E. Ex-Director of Records, Government of India. 2 vols. demy 8vo, 38s. net.

Sepoy Generals: Wellington to Roberts. With Portraits. Crown 8vo, 6s. 


\section{FORSTER.}

Where Angels Fear to Tread. By E. M. Forster. Crown Svo, 6 s.

The Longest Journey. Second Impression. Crown 8vo, 6s.

FOULIS.

Erchie: My Droll Friend. By HoGH Fodlis. Paper covers, 6d.; cloth, 1s. 6d. net.

The Vital Spark. Illustrated. 1s. net.

\section{FRASER.}

Philosophy of Theism. Being the Gifford Lectures delivered before the Unlversity of Edinburgh in 1894.96. By AlrXanden CAMpBel Fraser, D.C.L. Oxford; Emeritas Professor of Logle and Metaphysics in the Unlversity of Edinbargh. Second Editlon, Revised. Post 8vo, 6s. 6d. net.

Biographia Philosophica. In 1 vol. demy 8vo, 6s. net.

FRASER. The Marches of Hindustan : The Record of a Journey in Thibet, Trans-Himalayan India, Chinese Turkestan, Russian Turkestan, and Persia. By David Fraser. With Illustrations, Iaps, and Sketches. Demy svo, \&1, 1s. net.

FRENCH COOKERY FOR ENGLISH HOMES. Third Impression. Crown 8vo, limp cloth, 2s. 6d. Also in limp leather, 38.

FULTON. The Sovereignty of the Sea. An Historical Account of the Claims to the exclusive Dominion of the British Seas and of the Evolu. tion of the Territorial Waters, with special reference to the Rights of Fishing. By T. Wesyss Futton, M.D., F.R.S.E. Witl numerous Illustratious and Maps. Demy 8vo.

In the press.

\section{GENERAL ASSEMBLY OF THE CHURCH OF SCOTLAND.}

Scottish Hymnal, With Appendix Incorporated. Pablished for ase in Charches by Anthority of the General Assembly. 1. Large type, cloth, red edges, 28. 6d.; French moroceo, 48. 2. Bourgeols type, limp cloth, 18.: French morocco, 28. 3. Nonparell type, cloth, red edges, 6d.; French morocco, 18. 4d. 4. Paper covers, 3d. 5. Sunday-Bchool Edition, paper covers, 1d., cloth, 2d. No. 1, bound with the Psalms and Paraphrases, French morocco, 88 . Nc. 2, bond with the Psalms and Parap rases, cloth, 28.; French morocco, 38.

Prayers for Social and Family Worship. Prepared by a Special Cominittee of the General Assembly of the Church of Bcotland. Entirely Now Edition, Revised and Fnlarged. Fcap. 8vo, red edges, 1s. 6d. net.

Prayers for Family Worship. A Selection of Four Weeks' Prsyers. New Edition. Authortsed by the General Assembly of the Charch of Scotland. Fcap. 8vo, red edges 18. net.

One Hundred Prayers. Prepared by the Committee on Aids to Devotion. $16 \mathrm{mo}$, cloth limp, 6d.

Morning and Evening Prayers for Affixing to Bibles. Prepared by the Commlttee on Alds to Devotion. 1d. for 6, or 18. per 100.

Prayers for Soldiers. Prepared by the Committee on Aids to Devotion. Seventieth Thonsand. 16mo, eloth $11 \mathrm{mp}$. 2d. net.

Prayers for Sailors and Fisher-Folk. Prepared and Published by Instruction of the General Assembly of the Church of Scotland. Fcap. 8vo, 1s. net. 
GERARD.

Reata: What's in a Name. By E. D. Grrard. Cheap Edition. Orown 8vo, 8s. 6d.

Beggar my Neighbour. Cheap Edition. Crown 8vo, 38. 6d. The Waters of Hercules. Cheap Edition. Crown 8vo, 38. 6d. A Sensitive Plant. Crown 8vo, 3s. 6d.

GERARD.

'Honour's Glassy Bubble. By E. Gerard. Crown 8vo, 6s.

A Foreigner. An Anglo-German Study. Crown 8vo, 6s.

\section{GERARD.}

One Year. By Dorothea Grrard (Madame Longard de Longgarde). Crown 8vo, 6s.

The Impediment. Crown 8vo, 68.

A Spotless Reputation. Third Edition. Crown 8vo, 68.

The Wrong Man. Second Edition. Crown 8vo, 6s.

Lady Baby. Cheap Edition. Crown 8vo, 3s. 6d.

Recha. Crown 8vo, 6s.

A Forgotten Sin. Crown 8vo, 6s.

GIBBON.

Souls in Bondage. By Perceval Gibbon. Crown 8vo, 6s. Cheap Edition, royal $8 v 0$, paper cover, $6 \mathrm{~d}$.

The Vrouw Grobelaar's Leading Cases. Crown 8vo, 6s.

GILL. The $\mathrm{CHCl}_{3}$-Problem. By RichaRd Gill. 2 vols. crown $8 v 0,5 s$. net each.

GILLANDERS. Forest Entomology. By A. T. Gillanders, F.E.S. With Illustrations. Crown 8vo, 15s. net.

GLASGOW BALLAD CLUB. Ballads and Poems. By MemBERS OF the GLASGow BalLad Club. Third Series. Crown 8vo., 7s. 6d. net.

GLEIG. The Subaltern. By Rev. G. R. Gleig. Fcap. 8vo, 1s. net.

GRAHAM.

Manual of the Elections (Scot.) (Corrupt and Illegal Practices) Act, 1890. With Analysis, Relative Act of Sederunt, Appendix containing the Corrapt Practices Acts of 1883 and 1885, and Coplong Index. By J. EDWARD GRAGAM, Advoeste. 8vo, 48. 6d.

A Manual of the Acts relating to Education in Scotland. (Founded on that of the late Mr Craig Sellar.) Demy 8vo, 18s.

GRAHAM AND PATERSON. True Romances of Scotland. By E. Maxtone Gramam and E. Paterson. Illustrations. Crown Svo, 5s. net.

GRAND.

A Domestic Experiment. By SaraH Grand, Anthor of 'The Hesvenly Twing, 'Ideslai $\Delta$ Strudy from Iilfe.' Crown 8vo, 68.

Singularly Deleded Crovru 8vo, 6r.

GREY. Poems. By Dulcibella Ethel Grey. With a Prefatory Note by H. Cholmondeloy Pennell. Demy 8vo. Vellum, 12s. 6d. net; half vellum, $7 \mathrm{~s}$. $6 \mathrm{~d}$. net. 
GRIER.

In Farthest Ind. The Narrative of Mr-Edward Carlyon of Ellswether, in the County of Northsmpton, snd late of the Honourable Esst India Compsny's Service, Gentlemsn. Wrote by his own band in the year of grace 1697. Edited, with rew Explanstory Notes. By Sydney C. Grier. Post 8vo, 68.

His Excellency's English Governess. Third Impression. Cr. $8 \mathrm{vo}, 68$.

An Urcrowned King: A Romance of High Politics. Third Impression. Crown 8v0, 6s.

Peace with Honour. Third Impression. Crown 8vo, 6s.

A Crowned Qneen: The Romance of a Minister of State. Third Impression. Orown 8vo, 68.

Like Another Helen. Second Impression Crown 8vo, 6s.

The Kings of the East: A Romance of the near Future. Second Impression. Crown 8vo, 6s.

The Warden of the Marches. Third Impression. Crown 8vo, 68. Cheap Edition, paper cover, 6d.

The Prince of the Captivity. Second Impression. Crown $8 \mathbf{v} 0,6 \mathrm{~s}$.

The Advanced-Guard. Third Impression. Crown 8vo, 6s.

The Great Proconsul: The Memoirs of Mrs Hester Ward, formerly in the family of the Eon. Warren Hastings, Esquire, late Governor. General of Indis. Orown 8vo, 6s.

The Heir. Crown 8vo, 6s.

The Power of the Keys. With Illustrations by A. Pearce. Third Impression. Crown svo, 6s.

The Letters of Warren Hastings to his Wife. Demy 8vo, 6s, net.

GRIERSON. The First Half of the Seventeenth Century. (Periorls of European Literature.) By Professor H. J. C. Griersox. Crown 8 vo, $5 \mathrm{~s}$. net.

GRIFFIN.

Lady Sarah's Deed of Gift. By E. Aceituna Griffix. Crown $8 \mathrm{vo}, 6 \mathrm{~s}$.

A Servant of the King. Crown 8vo, 6s.

\section{HAMLEY.}

The Operations of War Explained and Illastrated. By General Sir EDWARd Bruck HAMLEY, K.C.B., K.C.M.G. Second Edition of Fifth Edition. With Maps and Plans. 4to, 30s. Also in 2 parts: Part 1., 108. 6d.; Psrt II., 218.

A New Edition, brought up to the latest requirements. By Colonel L. E. KIGGrel. 4to, with Mlaps and Plans, 30 s.

Thomas Carlyle: An Essay. Second Edition. Crown 8vo, 28. $6 \mathrm{~d}$.

On Outposts. Second Edition. 8vo, 28.

Lady Lee's Widowhood. New Edition. Crown 8vo, 28.

Our Poor Relations. A Philozoic Essay. With Illustrations, chiefly by Ernest Griset. Crown 8vo, cloth gilt, 38. 6d.

HANNAY. The Later Renaissance. "Periods of European Literature." By David Bannay. Crown 8vo, 58. net. 
HARRADEN.

Ships that Pass in the Night. By Beatrice Harraden. Illustrated Edition. Crown 8vo, 3s. 6d.

The Fowler. Illustrated Edition. Crown 8vo, 3s. 6d. Cheap Edition, paper cover, $6 \mathrm{~d}$.

In Varying Moods: Short Stories. Illustrated Edition. Crown 8vo, 38. 6d.

Untold Tales of the Past. With 40 Illustrations by H. R. Millar. Square crown 8vo, gilt top, 5s. net.

Katharine Frensham. Crown 8vo, 6s. Cheap Edition, paper cover, $6 \mathrm{~d}$.

HARTLEY. Wild Sport with Gun, Rifle, and Salmon-Rod. By GILFRID W. HARTLEY. With numerous Illustrations in photogravure and half. tone from drawings by $G$. E. LODGE and others. Demy 8 ro, 6 s. net.

HAY. "Pip." By Iax Hay. Third Impression. Crown 8vo, 6s. HAYLlaR. Nepenthes. By Florence Hayluar. Second Impression. Crown $8 v 0,6$.

HEMANS.

Select Poems of Mrs Hemenz. Fcap., cloth, gilt edges, 3s.

HENDERSON. The Young Estate Manager's Guide. By Richard Henderson, Member (by Examination) of the Royal Agricultural Society of England, the Highland and Agricultural Society of Scotland, and the Surveyors' Institution. With an Introduetion by R. Patrick Wright, F.R.S.E., Professor of Agriculture, Glasgow and West of Scotland Technicai College. With Plans and Diagrams. Crown 8 vo, $5 \mathrm{~s}$.

HENDERSON. The Minstrelsy of the Scottish Border. By Sir WaLTER Scotr. A New Edition. Edited by T. F. Henderson, Author of 'A History of Scottish Vernacular Literature.' With a New Portrait of Sir Walter Scott. In 4 vols., demy 8 vo, $£ 2,2$ s, net.

HERFORD. Browning (Modern English Writers). By Professor HERFord. Crown 8vo, 28, 6d.

HERKLESS AND HANNAY.

The College of St Leonard's. By Professor Herkless and RoBERT KERR HaNNaY. Post 8vo, 7s. 6d. net.

The Archbishops of St Andrews. Vol. I. Demy 8vo, 7s. 6d. net.

HINTS ON HOCKEY. With I'lans and liules. New Edition. Fcap. 8vo, 1s.

HOME PRAYERS. By Ministers of the Charct of Scotland and Members of the Caureh Service Society. Second Edition. Fcap. 8vo, 38.

HOPE. A History of the 1900 Parliament. By. James F. Hope. In two volumes. Vol. I. realy. Crowis brin, is. bid, net.

HUME. The Globular Jottings of Griselda. By E. Douglas Huse. With Illustrations. Demly $8 v 0,10 \%$. net. 
HUME. Dialogues concerning Natural Religion. By DAvid Home. Reprinted, with an Introduction by BrUCE $\mathrm{I}^{\prime} \mathrm{EWEN}$, D.Phil. Crown 8vo, 3s. 6d. net.

HUTCHINSON. Hints on the Game of Golf. By Horace G. Hutchinson. Twelfth Edition, Revised. Fcap. 8vo, cloth, 1s.

HUTTON. Italy and the Italians. By Edward Hutron. With Illustrations. Second Edition. Large crown 8vo, 68.

IDDESLEIGH. Life, Letters, and Diaries of Sir Stafford North . cote, First Earl of Iddeslelgh. By ANDREw Lang. With Three Portrsits and a Vlew of Pynes. Third Edition. 2 vols. post 8vo, 31s. 6d.

Popular Edition. With Portrsit and View of Pynes. Post 8vo, 38. 6d.

INNES.

Free Church Union Case. Judgment of the House of Lords. With Introduction by A. TAYLOR INNEs, LL. D. Demy Svo, 1s, net.

The Law of Creeds in Scotland. A Treatise on the Relations of Churehes in Scotlsnd, Established and not Established, to the Civil Law. Demy 8vo, 10s. net.

INTELLIGENCE OFFICER.

On the Heels of De Wet. By The Inteluigence Officer. Sixth Impression. Crown 8vo, 6s. Cheap Edition royal 8vo, psper cover, 6d.

The Boy Galloper. With Illustrations. In 1 vol. cr. 8vo, 6s.

The Yellow War. Crown 8vo, 6s. Cheap Edition, paper cover, $6 \mathrm{~d}$.

A Subaltern of Horse. Second Impression. Crown 8vo, $6 \mathrm{~s}$.

IRONS. The Psychology of Ethics. By David Iroxs, M.A., Ph.D. Professor of Philosophy in Bryn Mawr College, Penn. Crown 8vo, ss, net.

JAMES. William Wetmore Story and his Friends. From Letters, Diaries, and Recollections. By HeNRY JAyes. With 2 Portraits. In two vols. post 8 vo, 248 . net.

JAMES.

Modern Strategy. By Lieut.-Col. Walter H. James, P.S.C., late R.E. With 6 Maps. Second Edition, thorouglly revised and brought np to date. Roysl 8vo, $16 \mathrm{~s}$. net.

The Campaign of 1815, chiefly in Flanders. With Maps and Plans. Demy Sro, 16s. net.

The Development of Tactics from 1740 to the Present Day. Demy 8vo.

In the press.

JOHNSTON.

Elements of Agricultaral Chemistry. An entirely New Edition from the Edition by 8ir Charleg A. Camzron, M.D. F.13.C.S.I. \&c. Revised and bronght down to date by C. M. A'xMAN, M.A., B.Sc., F.R.S.K.. Professor of Chemictrv. Glasgow Veterinarv College. 17th Edition. Crom 8 vo, 68. กd.

Catochism of Agricultural Chemistry. An entirely New Edition from the Edition by Sír Charleg A. Cameron. Revised and Enlarged by C. M. AIxMAN M.A \&c. 95th Thunsand. With unmerong Illustrations. Crown 8vo, 18. 
JOHNSTON. Agricultural Holdings (Scotland) Acts, 1883 to 1900 ; and the Ground Game Act, 1880. With Notes, and Summsry of Procedure, \&c. By Christopher N. Jofiston, M.A., Adrocsto, Fifth Edition. Demy Svo, 6s. net.

JOKAI. Timar's Two Worlds. By Mauros JokaI. Aathorised Translation by Mrg Hrgan Krinard. Chesp Edition. Crown 880, 68.

KENNEDY. Hurrah for the Life of a Sailor ! Fifty Years in the Royal Navy. By Admiral Sir William Kensedy, K.C.B. With Illustrations from Sketches by the Author. Fifth Impression. Demy 8vo, 12s. 6d.

Cheaper Edition, small demy Svo, $6 \mathrm{~s}$.

KER. The Dark Ages. "Periods of European Literature." By Professor W. P. KER. In l vol, crown svo 5s. net.

KERR.

Memories: Grave and Gay. By JoHn Kerr, LL.D. With Portrait and other Illustrations. Cheajer Edition, Enlar'sed. Crown 8vo, 2s. $6 r$. net.

Other Nemories: Old and New. Crown 8vo. 3s. 6d. net.

\section{KINGLAKE}

History of the Invasion of the Crimea. By A. W. Kinalake. Complete in 9 vols., crown $8 v 0$. Ciean reissue at 3 s. 6 d. each.

- Abridged Edition for Military Students. Revised by Lient.-Col. Sir George 8ydeneam Clakke, K.C.M.G., R.E. Demy 8vo, 15s. net. - Atlas to accompany above. Folio, 9s. net.

History of the Invasion of the Crimea. Demy 8vo. Vol. VI. Winter Tronbles. With a Map, 16s. Vols. VII. and VIII. From the Morrow of Inkermsn to the Desth of Lord Baglan. With an Index to the Whole Work. With Maps and Plans. 28s

Eothen. A New Edition, aniform with the Cabinet Edition of the 'History of the Invasion of the Crimea' $c$.

Cheaper Edition. With Portrsit and Blographical Sketch of the Author. Crown 8v0, 28. 6d. net.

KNEIPP. My Water-Care. As Tested through more than Thirty Yesrs, and Described for the Healing of Disesses and the Preservation of Heslth. By SUBASTIAN KNEIPP. With a Portrait and other lllustrations. Authoriged English Translation trom the Thirtieth German Ldition, by A. de F. With an Appendix, coutainin the Latest Deviopments of Plarrer Kneipp's System, and a Prefsce by E. Gerard. Crown 8vo, 3s. 6d.

LANG.

A History of Scotland from the Roman Occupation. By Andrew Lano. Comlete in Fonl Vulumes. Demy 8vo, t3, 3s. net.

Vol. I. With a Photogravire frontisniece. 15s, net.

Vol. II. With a Plotogravure Frontisniece. 15s, net.

Vol. III. With a Photogravure Eroutispiece. 15s. net.

Vol. IV. With a Plotorravire Frombisulece. 20s. net.

Temnyson. "Nlodern English Writers." 2nd Ed. Cr. 8vo, 2s. 6d. Life, Letters, and Diaries of Sar. Stafiord Northcote, First Esrl of Iddesleigh. With Three Portrsits and a Vlew of Pynes. Third Edition. 2 vols, post $8 \mathrm{vo}, 31 \mathrm{~s}$. "ä.

Popular EDition. With Portrait snd View of Pynes. Post 8vo, 3s. Bd.

The Highlands of Scotland in 1750. From Manuscript 104 in the King's Library, British Musenm. With an Introduction by ANdrew Lavo. Orown 8vo, 58. net. 


\section{LANG.}

The Expansion of the Christian Life. The Duff Lecture for 1897. By the Rev. J. Marshall Lang, D.D., Principal of the Uuiversily of Aberdeen. Crown $8 \mathrm{vo}, 5 \mathrm{~s}$.

The Church and its Social Mission. Being the Baird Lecture lor 1901. Crown $8 \mathrm{vo}, 6 \mathrm{~s}$, net.

\section{LAWSON.}

British Economics. By W. R. Lawsox. Crown 8vo, fis. net.

American Finance. Part First-Domestic. Crown 8ro, 6s. net.

John Bull and His Sichools. C'rown sio, fis. net.

LEHMANN. Crumbs of Pity, and other Verses; to which are added Six Lives of Great Men. By R. C. LEHMAN, author of 'Anni Furares, \&c. Crown svo, 5s. net.

LEIGHTON. The Life History of British Serpents, and their

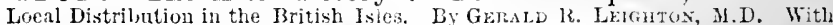
50 Illustratious. Crown 8vo, 5s, net.

LEISHMAN. The Westminster Directory. Faited, with an Introduction and Notes, by the Very Rev. T. Lershax D. D. Crrinn sro 4 s. net.

\section{LINDSAY.}

Recent Advances in Theistic Philosophy of Religion. By Rev. Jamrs Lindsay, M.A., D.D., B.Sc., F.R.S.E. F.G.S., Minister of the Purish of St Andrew's, Kilmarnock. Deny 8vo, 12s. lid. net.

The Progressiveness of Modern Christian Thnught. Crown $8 \nabla 0,68$.

Essays, Literary and Philosophical. Crown 8vo, 3s, 6d.

The Significance of the Oid Testament for Modern Theology. Orown $8 \mathrm{ro}$, 18. net.

The Teaching Function of the Modern Pulpit. Crown 8vo, 18. net

"LINESMAN." Words by an Eyewitness: The Strugrele in Natal. By "I.risssas." Eleventh Impression, with Three Aduitimul Chaliters. Crown 8vo, 6s.

\section{LITURGIES AND ORDERS OF MIVINE SERTLC} (CIIURCII SELVICH SOCLET).

The Second Prayer Book of King Flward the Sixth (15.2).

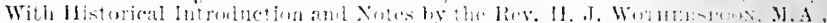

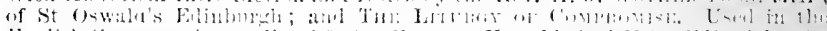

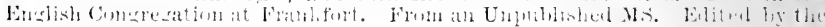

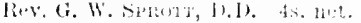

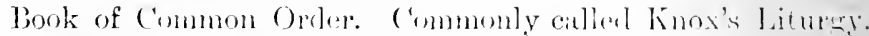

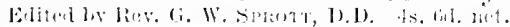

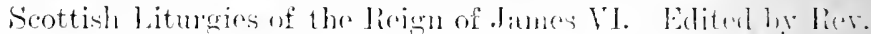

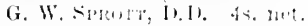

Liturey of 16:37. Commonly callerl Laud's litures. bilited

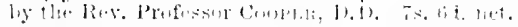

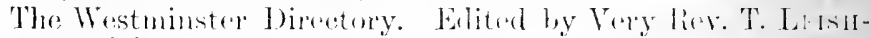

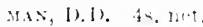

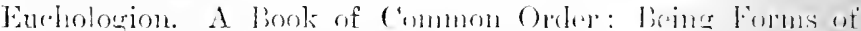

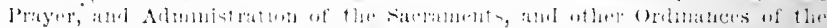

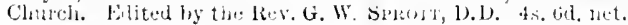


LOBBAN. An Anthology of English Verse from Chaucer to the Present bay. ByJ. H Lubhax, M.A. Crowa 8vo, gilt top, 5s.

LOCKHART.

Doubles and Quits. By Lacriace W. M. Lochmart. Cheap Edition. Royal sio, petper covers, 6d.

Mine is Thine. New Edition. Crown 8vo, 38. 6a.

LORIMER. The Author's Irogress: or, The Literary Book of the Road. By Abas Lurmer. Crom sro, ss. net.

LYNDFN - BELL. A Primer of Tactics, Fortitication, Topography, aud Military Law. By Lieut.-Coloncl C. P. Ly NDEx-BeLz. With Diagrams Crown svo, 3s. net.

\section{MABIE.}

Essays on Nature and Cultare. By Bamilton Wright Mabif. Witk Portrsit. keak. $8 \mathrm{vo}, 3 \mathrm{n}, \mathrm{nd}$.

Books and Culture. Fenp. 8vo, 3s. 6d.

M'AUlaY. The Safety of the Honours. By Allax M'Aulay. Crown sio, es.

MACDUNALD. A Manual of the Criminal Law (Scotland) Pro. cedure Act, 1857. By Noryan Doran Macponatd. Reviged by the Lord JUSTIC T-CLERK. 8yo 10s. 6d

MACKAY. The Return of the Emigrant. By Lyda MrLen

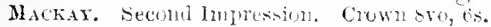

MACKENZIE. Studies in homan Law, With Comparative Views of the Laws of France. Engiand, and Sentland. By Lord Mackrinit, one of the Judges of the Court of Sissiun in Scotlind. Seventh Fdjtion, Editer by Jön KIRKPatrick, M.A., LL.J., Adrocate, Protessor of History in the Unversity of Edinburgh. 8vo, 2l.

MACLEOD. The I)octrine and Valielity of the Ministry and

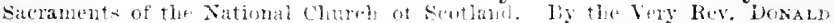

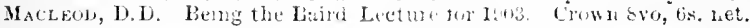

\section{MACPHELSON.}

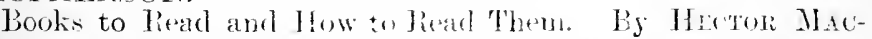

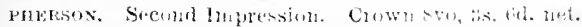

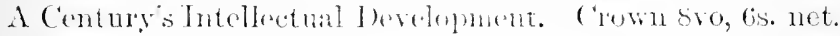

A Century of l'olitical lorelopment. fine nut.

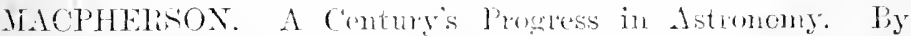

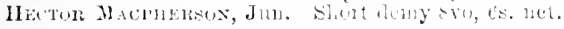

MLIII:

A Digest of Laws and Deciciors Ecclestastical and Civil, relating to the Constitutinn, Fractiate and Affairs of the Chmols of scotland. With Sotes und Forins of Finedure. By the Rev. Wuldas Malp. D.D., latery Minister of the Parish of Larlston. New Edition, Revised. In I vol. crown svo, 12s. 6d. net. 
MAIR.

Speaking; or, From Voice Production to the Platform and Pulpit. Third Edition, Revised. Crown 8 vo, $3 \mathrm{~s}$.

MARSHMAN. History of India. From the Earliest Period to tho present time. By John Crark Marshane, C.S.I. Third and Cheaper Edition. Post 8vo, with Msp, 6s.

\section{MARTIN.}

Poems of Giacomo Leopardi. Translated by Sir Turodore Martis, K.C.B. Cruwn sro, 5s. net.

The Aneid of Virgil. Books I. VI. Translated by Sir TheoDORE MARTis, K.C.B. Post 8vo, 78. 6d.

Goethe's Faust. Part I. Translated into English Verse. Second Edition, crown 8ro, 8s. Ninth Elition, fcap. 8vo, 3s. 6 d.

Goethe's Faust. Part II. Translated into English Verse. Second Edition, Revised. Fcap. 8vo, 6s.

The Works of Horace. Translated into English Verse: with Life and Notes. 2 vols. Few Edition. Orown svo, 21 .

Poems and Ballads of Heinrich Heine. Done into English Verse. Third E tition. Snall crown 8 vo, 5 s.

The Song of the Bell, and other Translations from Schiller, Goethe, Uhland, and Others. Crown $3 \mathrm{vo}, 7 \mathrm{~s} .6 \mathrm{~d}$.

Madonna Pia: A Tragedy ; and Three Other Dramas. Crown 8vo. 78. 6d.

Catallus. With Life and Notes. Second Edition, Revised and Corrected. Post 8vo, 78.6d.

The 'Vita Nuova' of Dante. Translated with an Introduction and Notes. Fourth Edition. Small crown ovi, $5 \mathrm{~s}$.

Aladdin: A Dramatic Poem. By A.dam Okhlexschlakger. Fcap. 8vo, 5s.

Correggio: A Tragedy. By Oehlenschuakexers. With Notes. Fap. 8vo, 3s.

Helena Faucit (Lady Martin). By Sir Thfonorf MARTw,

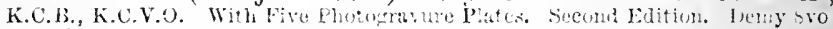
10s. Gl. wit.

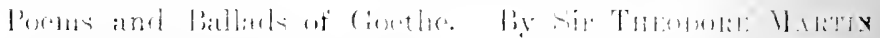

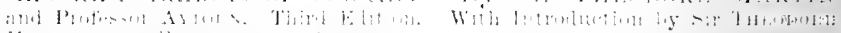

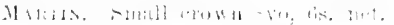

MARTIN. On some of Shakespene's Fenale Characters. By

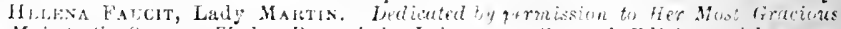
Mugesty the Queen. Writh a Pertrait by Lehmann. Serinth Edition, with a new Pretace. Demy 8vo, 7s. 6d. 


\section{MATHESON.}

Can the Old Faith Live with the New ? or, The Problem of Evointion and Revelation. By the Rev. Giongr Mathrgon, D.D. Third Edition. Crown 8vo, 7s. $8 \mathrm{~d}$.

The Psalmist and the Scientist ; or, Modern. Value of the Reli. gions Sentiment. Third Edition. Crown 8 vo, 58 .

Spiritual Development of St Paul. Fourth Edition. Cr. 8vo, 58.

The Distinctive Messages of the Old Peligions. Second Edition. Crowe $8 \mathrm{vo}, 58$.

Sacred Songs. Third Edition. Crown 8vo, 24. ต̉d.

MAUGHAM. Richard Hawkwood. By H. N. MaUghaM. A Romance. Crown 8 vo, 6 s.

\section{MAXWELL.}

Dumfries and Galloway. By Right Hon. Sir Herbert Maxweld, Bart. Being one of the Volnmes of the Connty Histories of scotland. With Four Maps. Seeond Edition. Đemy ovo,7s. 6d. net.

Scottish Land-Names: Their Origin and Meaning. Being the Rhind Lectures in Arrheolory for 1893. Post 3vo, 68.

Holyrood, Abbey Church, Palace,"and Environs." Crown sro. Paper cover, bid. het; cleth, 2s. ficl. net.

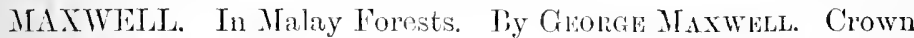
Svo, tis. net.

\section{MELDRUM.}

The Conquest of Charlotte. By David S. Mefdrom. Third Impression. Crewn svo, bs.

Holland and the Hollanders. With numerous Illustrations and a Map. Second Edition. Square Svo, 6s.

The Story of Margrédel : Peing a Fireside History of a Fife. shire Family. Cheap Edition Crown 8vo, 3s. 6d.

Grey Mantle and Gold Fringe. Crown 8vo, 68.

\section{MELLONE.}

Studies in Philosophical Criticism and Construction. By Sydney Hermert Melzonx. M.A. Lond., D. Sc. Edin. Post 8vo, 10s. 6d. not.

Leaders of Religious Thought in the Nineteenth Century. Crown Svo, Bs. net.

An Introductory Text-Book of Logic. Śecond Edition, Reviserl. Crown sro, $5 \mathrm{~s}$.

Elements of Psychology. Crown svo, as.

MERZ. A History of European Thought in the Nineteenth Century. By Johs Theodore Merz. Vol. I., post 8vo, 10s. 6d. net. Vol. II., 15s. net.

MEYNELL. John Riuskin. "Modern English Writers." By Mrs MeYNell. Third Impression. Crown 8vo, 2s. bd.

MICHIE. The Englishman in China during the Victorian Era. As Illustrated in the Life of Sir Rutherfo'd Alcosk, K.C.B., I).C.L. By ALEX. ANDer Mrchre. With Illustrations, Portraits, and Maps. 2 vols. demy 8vo, 38s. net.

MICKLETHWAIT. The Licensing Aet, 1904. By St J. G. Mickletrwait, M.A., B.C.L., Barrister-at-Law. Crown 8vo, 2s. 6d. net. 
MILL.

The Colonel Sahib. A Novel. By Garretr Mrlu. Second inpussion. Crown bro, 6 s.

Ottavia. Second Impression. Crown 8vo, 6s.

Mr liontgomery : Fool. Crown 8vo, 6s.

In the Hands of the Czar. Crown 8ro, $6 \mathrm{~s}$.

The Cardinal's Secret. Crown 8ro, 6s.

MILLAR. The Mid-Eighteenth Century. "Periods of European Literature." By J. H. Millar. Crown 8vo, 5s. net.

IIITCHELL. The Scottish Reformation. Being the Baird Lecture for 1899. By the late Alexasokr F. MiTenkil, D.D., LL.D. Edited by ?. HaY Flemixi, LI.D. With s Biographical Sketch of the Aluthor, by James Christie, D,D Crown svo. B4.

MITCHELT. Signifient Ftymolngy. By Rer. Turms MrTritet, , 1). D. Slurt inmy sro.

[1, the juise.

MODERN ENGLISH WRITERS. In handy crown 8vo volumes, tastefully bound, price 2s. Bit. esch.

Watthew Arnold. By Professor SAintsbury. Second Impression.

R. L. Stevenson. Pv L. Cope Corxaron. Second Impression. John Ruskin. By Mrs Mfryxule. Third Impression.

Tennyson. By Axprew Laxa. Second Edition.

Huxley. By Enward Cronn.

Thackeray. By Cmarles Whibley.

Prowning. By Prof. C. H. Herforen.

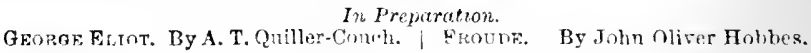

MOLR. Life of Mansie Wauch, Tailor in Dalkeith. By D. M. Molr. With Croiksimak's Illustrabions. Cheaper Fdition. Crown 3vo, 2a, fid.

\section{KOMERLE.}

I) Alfred Momerie. His Life and Work. By Mrs Momerus. Demy swo, 12s. Pit. net.

The Orien of Evil, and other Sermone. By liev. Alfied

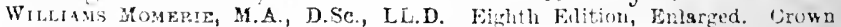
$8 \mathrm{vo}, \mathrm{i}, \mathrm{s}$

Personality. The Beginning and Fnd of Metaphysics, and a Ne. cessary Assumption in s!l Positive Plilosuphy. Fitth Ed., Nevised. Cr. 8vo, as.

Agnostrcism. Fourth Edition, Revised. Crown 8vo, 58.

Preaching and Hearing; and other Sermons. Fourth Edition, Enlarged. Urowa 8vos, 5s.

Belief in God. Fourth Edition. Crown \&ivo, 3s.

The Futare of Religion, and other Essibys. Second Fdition. Crown evo, 3\%. 6d.

The English Church and the Romigh Schism. Second Fdition. 1.rown \&vo, 2s. rit

liseitys on tho liible. ( pownsiro.

I J the pors. 
MONTAGUE. Military Topography. Illustrated by Practical Examples of a Practical Subject. By Major-General w. E. Montague, C.B., P.S.C., late Garrison Iustructor Inteligence Department, Author of 'Campaign. ing in Bonth Afries.' With Forty-one Disgrams Crown svi, ss.

MUNRO. The Daft Days. Third Tmpression. By Neil Monno. Crown svo, os.

\section{Uniform Edition Novels.}

John Splendid. The Tisle of a Foor Genteman and the Little Wars of Lorn. Sixth Impression Crown 8vo. 3s 6d.

Children of Tempest: A Tale of the Outer Isles. Crown $8 \mathrm{vo}, 3 \mathrm{~s}$. fid.

Shoes of Fortune. Crown 8vo, 3s. $6 \mathrm{~d}$.

The Lost Pibroch, and other Sheiling Stories. Fourth Impression. Crown 8 vn, 3s. 6 d

Doom Castle: A Romance. Second Impression. Crown Svo, 3s. kel

Gilian the Dreamer. Crown 8vo, 3s. 6d.

MUNRO.

Rambies and Studies in Bosni:-Herzogovina and Dalmatia. By Ronrrt Munfo, M.A., M.D. LL.I,, F.R.S.E. Second Edition, Revised and Enlarged. With numerous illustrstions. Demy 8vo, 12s. 6d. net.

Prehistoric Problems. With numerous Illustrations. Demy \&vo, 10s. net.

MUNRO. On Valuation of Property. By William Munro, M.A. Her Majesty's Assescor of Rnilways and Canals for Seotland. Second Edition, Ruvised avd Enlarred. 840, 3r. bd,

MIYRES. A Manual of Classical Geography. By John L. Mrres. Crown sro.

[In the press.

NEWCOXIBE. Village, Town, and Jungle Life in India By

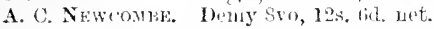

NICHOLSON AND LIJEKKER.

A Manual of Palæostology, for the Use of Students. With a General Introduetion on the Principles of Paltontology. By Professor H. A Lleynk Nicholson and Rehard hydekier, B.A. Third Edition, endirely Rewritten and greatly Fnlargeit. 22 rols. 8 wo, E3, 38.

NICOL. Recent Archrology and the Bible. Being the Croall Lectures for 189s. By the Rev. Thomas Nicor. D.D., Protessor of Divinity snd Biblical Critiefsm in the University of Aberdeen; Author of 'Recent Ex. plorations in Bible Lands.' Deny 8vo, 9s. net.

NISBET. The Forester : A Practical Treatise on British Forestry and Arboricenture for Landowners, Latnd Afents, and Foresters. By Jous NisBet, D.(E). In 2 volumes, royal Sro, with 283 fllustrations, $42 s$. net.

NOPLE.

The Edge of Circumstance. By Enward Norle. Crown 8vo, 6s. Chetap Ertition, royit svo, laler cover, bi.

Waves of Fate. Crown 8ro, 6s.

Fisherman's Gat: A Story of the Thames Estuary. Crown svo, 6s. 
NOYES.

Poems by Alfred Noyes. 7s. 6d. net.

The Forest of Wild Thyme: A Tale for Children under Ninety. Crown sro, 5s, net.

Drake: An English Epic. Books I.-III. Crown 8ro, 5s. net. Forty Singing Seamen. Crown sro, 5s. net.

O. The Yellow War. By O. Crown 8vo, 6s. Cheap Erlition. Royal sro, 6 .

\section{OLIPHAN'T.}

Piccadilly. With Illustrations by Richard Doyle. New Edition, 3s. 6d. Chesp Edition, boards, 2s. 6d. Episodes in a Life of Adventure; or, Moss from a Rolling
Stone. Cheaper Edition. Post Bvo, 3s. 6d.

\section{OLIPHANT.}

Annals of a Publishing House. William Blackwood and bis Sons; Their Magazine and Friends. By Mrs OLIPANT. With Fotr Portraits. Third Edition. Demy svo. Vols. I. and II. $£ 2,2 \mathrm{~s}$.

A Widow's Tale, and other Stories. With an Iritroductory sote by J. K. Barrix. Second Edition. Gown 8vo, 8s.

Katie Stewart, and other Stories. New Edition. Crown 8vo, cloth, 38. 6d.

Katie Stewart, Illustrated boards, 28. 6d.

Valentine and his Brother. New Edition. Crown 8vo, 3s. 6d.

Sons and Daughters. Crown 8vo, 3\%. 6d.

OMOND. The Romantic Triumph. "Periods of European Literature." By T. S. Omosd. Crown svo, 5s. net.

()'NEML. Songs of the Giens of Antrim. By Morra O'N EILL. Twelfth Impression. Crown svo, 3s. fid. 
PAGE.

Intermediate Text-Book of Geology. By Professor Lapwortm. Foundel on Dr Page's 'Introluctory Text-Brok of Geology.' Crown 8vo, $5 \mathrm{~s}$.

Advanced Text-Book of Geology. New Edition. Revised and enlarged by Professor Lapworth. Crown sro.

Introductory Text-Book of Physical Geography. Crown Sro, 2s. $6 \mathrm{~d}$.

Advanced Text-Book of Physical Geography. Crown 8vo, 5s. Physical Geography Examinator. Crown 8ro, sewed, 9d.

PARKFR. Miss Lomax: Millionaire. By Bessie Parker. Crown Sro, 6s.

PATERsox. Peggotts; or, The Indian Contingent. By MarGaiet Paterson. Crown sro, os.

PAUL. History of the Royal Company of Archers the Queen's Body-Guard for Scotiand. By Sir JAMEs BALFour PAUL, Advoeste of the Scottisb Bar. Crown 4to, with Portraits and other lllustratious, $\underset{\varepsilon 2}{2} 2$.

PEARSE The Hearseys: Five Genmations of an Anglo-Indian Family. By Colonel liegn Peans, 11.5.0. Demy sro, 15s, net."

PERIODS OF EUROPEAN LITERATURE. Edited hy Professor SAINTSBCRY. For List of Volumes, see prge 2.

PHILOSOPHICAL CLASSICS FOR ENGLISH READERS. Elited by William KNight, LL.D.. Profesagr of Moral Philosophy, University of St Andrews. Cleap Re-issue in Shilling Volunes nct.

[For List of Volumes, see page 2.

POLLOK. The Course of Time: A Poem. By Robert Polloz, A.M. New Edition. With Portrait. Fcap. 3vo, zilt top, 2s. 6d.

POLLOK. Studies in Practical Theology. By Altax Pollok, D.D., LL.D. Crown Sio, 5s, net.

\section{PRINGLE-PATTISON.}

Scottish Prilosophy. A Comparison of the Scottish and Germsn Auswers to Hume. Balfour Philosophical Lectures, University of Edinhnrgh. By A. Setri Ppingle-P.itrison, LL.D., O.C.L., Fellow of the British A alteny, Prolessur of Log e an Metaphysics in Edinblirgh University. lourth Edition. Crown 8vo, 5s.

Hegelianism and Personality. Balfour Philosophical Lectures. Second Series. Second Edition. Crown 8vo, 5s.

Man's Place in the Cosmos, and other Essays. Second Edition, Enlaroed. Post 5ro, 6s, net

Two Lectures on Theism. Delivered on the occasion of the Sesquicentennial Celebration of Princeton University. Crowu 8vo, 2s 6d.

The Philosophical Tadicals and Other Essays, including

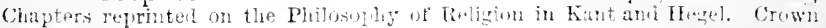
Svo, 6s. net. 
PUBLIC GENERAL STATUTES AFFECTING SCOTLAND from 1707 to 1847 , with Chronologiesl T'sble snd Index. 3 vols. large 8 vo, £3, 38 . Also Published Annually with General Index.

QUESTION OF COLOUR, A. A Study of South Africa. Crown svo, 6s, net.

RANJITSINHJI. The Jubilee Boors of Cricket. By Prince Ranjtatinut.

Popular Enition. With 107 full-page Illnstrations. Sixth Edition. Large crown $8 \mathrm{vo}, 8 \mathrm{~s}$.

Sixpenxy EDrtios. With a selection of the Illustrations.

\section{ROBERTSON.}

The Poetry and the Religion of the Psalms. The Croall Lectures, 1593-94. By Ja3ies Robfrtsos, D. D., Proifssor of Oriental Languages in the University of Giasgow. Demy 5 ro, $12 \mathrm{~s}$.

\section{ROBERTSON.}

A History of Gemman Literature. By Jomx G. liobretsox, 1'h.1)., Professor of German, University of London. Deny swo, 10. bil. net.

Schiller after a Century. Crown $8 \mathrm{ro}$, 2s. 6d. net.

\section{RONALDSHAY.}

On the Outskirts of Empire in Asia. By the FArL of Rosaldshay, Mll'. With mumerons lllustrations ami Mais. Royal Sw, 21s. net

Sport and Politics undor an Eastern Sky. With numerous Illustrations aurl Mlays. Rougl Swo, $21 \mathrm{~s}$. net.

\section{RUTLAND.}

Notes of an Irish Tour in i816. By the Duke of Rutuaxd,

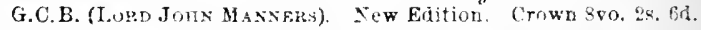

Correspondence between the Right Honble. William Pitt and Charies Dnke of Rutland. Lord-Lifutenant of Ireland, 1781-1787. Witk

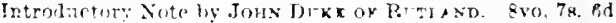

The Collected Writings of Janotta, Duchess of Rutland. With Portrast and Inustrations. 2 vols. post $8 \mathrm{rn}, 15 \mathrm{~s}$. net.

Impressions of Pad-Homburg. Comprising a Short Acconnt

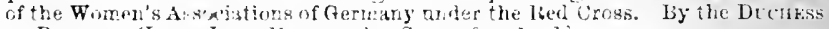

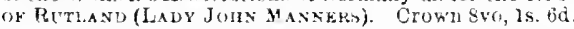

Sone Personal Pimollections of the Later Years of the Eari of Beacousficld, R.G. Siath Edition. 6d.

Enployment of Womeri in the l'ublic Services. Gd.

Some of the Advantages of Farily Accessible Readine and kerestion Roorny and Fres Librarieg. Witis Lemarks on Starting and Main. taining thent. Secoud Edition. Crown 8 vo, 18 . 


\section{RUTLAND.}

A Sequel to Rich Men's Dwellings, and other Occasiona) Papers. Crown 8vo, 2s. 6d.

Encouraging Experiences of Reading and Recreation Rooms, Aims of Guilds, Nottingham Social Gride, Existing Institutions, \&c., \&c. Crown 8vo, 18 .

\section{SAINTSBURT.}

A History of Criticism and Literary Taste in Europe. From the Earliest Texts to the Present l)ay. By George SalnTsgury. M.A. (Oxon.) Hon. LI.D. (Aberd.), Professor of Rhetoric and English Literature in the Univer sity of Edinburgh. In 3 vols. demy 8vo. Vol. 1.-Classical and Medieval Criti. eism. 16s. net.

Vol. II.-From the Rensissance to the Decline of Eighteenth Century Ortho. doxy. 20s. net.

Vol. III.-Nineteenth Century. 20s. net.

Matthew Arnold. "Modern English Writers." Second Edition. Crown 8vo, 2s. 6d

The Flourishing of Romance and the Rise of Allegory (12th and 13th Centuries). "Periods of Eurnpean Literature." Crown Svo, 5s. net.

The Farlier Renaissance. "Periods of European Literature." crown svo, 5s, net.

The Later Nineteenth Century. "Periors of European 1.iterature" "Crown smo, 5s. nut.

"SCOLOPAX." A Book of the Snipe. By Scolopax. Inhstrated. Crown $8 \mathrm{rn}, 5 \mathrm{~s}$. net.

SCOTT. Tom Cringle's Lng. Py Michazl Scotr. New Edition. With 19 Full-page Ilmstrations. Crown $8 v 0,38.6 \mathrm{~d}$.

SCUDAMORE. Belgium and the Pe!gians. By Crril ScudaMORE. With Illnstrations. Square reosn sin, tis.

SELLAR. Teeollections and Tmpressions. By R. M. SELLAR. Witl Eiglit Portraits. Fourth lmpursion. bemy swo, ios. til. net.

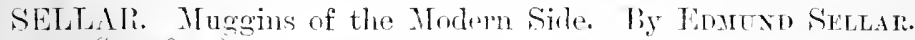
(rown $8 \mathrm{w}$, tis.

SETH. A Study of Fthical Principles. By .Taves Seth, M.A., Professor of Horai Philosoliny in the University of Edinburgh. Eighth Edition, Revised. Post 8vo, 7s. Bd.

SHARPLEY. Aristoplanes-Pax. Erlited, with Introduction and Notes, by H. Sirnisex. Demy 8vo, 12s. 6l. net.

SHAW. Securities over Moveahles. Four Lectures delivered at the Request of the Society of Accountants in Eilininurch, the institute of Accountauts and Actuaries in Glasgow, and the Institute of Dankers in scotlancl, in 1902-3. Deny swo, is. that. net.

SLMPSON. Side-Lights on Siberia. Some account of the Great Siberian ficn Foad: Tho Prisons and Exile System. By Professor J. X. Simpson, D.Sc. With unmerous Illustrationz aud a Map. Demy xvo, 168.

SINCLAIP. The Thistle and Fleur de Lys: $\Lambda$ Vocabulary of Franco-Scottinh Worls. By tsabet G. Sin'tarr. Crown Evo, 3s. net. 
SKELTON. The Handbook of Public Health. A Yew Edition, Revised by James Patrex Macuoggall, Adrocate, Secretary to the Lumal Government Board for Scotland, Joint-Author of 'The Parish C'mancl Gnisle for

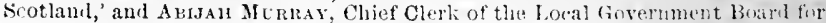
Scotland. In Two Parts. Crown Svo. Part 1.-The P'allic Itealth (Seutlani) Act, 1897, with Notes. 3s. 6d. net.

SKRINE. Fontenoy, and Great Britain's share in the War of the Austrian Suceession. By F. H. SKrne. With Map, Plans, and Illustriltions Demy 8vo, 21s. net.

\section{SMITH.}

The Transition Period. "Periods of European Literature." By G. Gregory Syith. Crown Svo, 5s. net.

Specimens of Middle Scots. Post 8vo, 7s. 6d. net.

SMITH. Retrievers, and how to Break them. By LieutenantColcnel Sir HeNRY SMith, K.C.B. With an Introduction by Mr S. E. SHinters, President of the Kennel Club. Dedicated by special permissiun to H.R.F. the Duke of Cornwall and York. Crown Svo, 5s.

SNELL. The Fourteenth Century. "Periods of European Literature." By F. J. SseLt. Crown 8vo, 58. net

"SON OF THE MARSHES, A."

From Spring to Fall; or, When Life Stirs. BY "A SoN (1F the Marshes." Cheap Uniform Edition. Cruwn 8vo, 3s. jd.

Within an Hour of Lordor Town: Among Wild Birds and

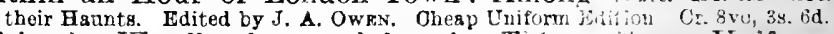

With the Woodlanders and by the Tide inesp Uniforn? Edition. Crown 8vo, 3s. 8 d.

On Surrey Hills. Cheap Uniform Edition. Cown 8vo, 38. 6d.

Annals of a Fishing Village. Cheap Uniform Vidion. Crown 8vo, 3s. 6d.

\section{SORLEY.}

The Fthics of Naturalism. By W. R. Soruey, fitt.])., Г..І.|)., Fellow of the British Acarkmy, Fellow of Trinity (Nollege, Camberidge, Profeeser of Moral Philosophy, University of Cambridte. Serom Ealition. Cruwn sio Bs.

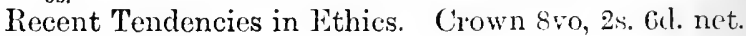

\section{SPROTT.}

The Worship and Offices of the Church of Scotland. liy George W. SProtT, D.D. Crown Svo, tos.

The Book of Common Order of the Church of Seotland, commonly known as John Knox's Liturgy. With historical Intrerlactiun and Mllustrative Notes. Crown $8 \mathrm{ro}, 4 \mathrm{~s}$, bid. net.

Scottish Liturgies of the lieign of James VI. Edited, with an introduction and Notes. Crown svo, 4s. net.

Eucluslogion: A Jook of Common Order. Crown 8ro, 4s. 6ill. net.

\section{STEEVENS}

Things Seen: Impressions of Men, Citres, and Books. By the

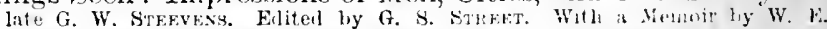
Hextek, and a Photogravure reprowluction of collier's Portrait. Memorial bili tim. Crown svo, 6s. 
STEEVENS.

From Capetown to Ladysmith, and Egypt in 1898. Memorial Edition. Crown 8vo, 6s.

In'India. With Map. Memorial Edition. Crown 8vo, 68.

Witb Kitchener to Khartum. With 8 Maps and Plans. Ifemorial Edition. Crown 8vo, 68.

The Land of the Dollar. Memorial Edition. Crown 8vo, 6s.

Glimpses of Three Nations. Memorial Edition. Cr. 8vo, $6 \mathrm{~s}$.

Monologues of the Dead. Memorial Edition. Crown 8vo, 3s. 6d.

With the Conquering Turk. With 4 Maps. Ch. Ed. Cr. 8vo, 6s.

STEPHENS.

The Book of the Farm; detailing the Labours of the Farmer, Farm-Steriard, Ploughman, Shepherd, Hedger, Farm-Labourer, Field-Worker, and Cattle-war. Illistrsted with numerous Portraits of Animals and Engravings of Inplenents, anc? Pians of Farm Buildings. Fourth Edition. Revised, and in great part Re-written, by JAMEg MACDONALD, F.R.S.E., Secrotary Highland snd Agriculturai Society of Scotland. Compiete in Six Divisional Volumes, bound ir cloth, esch 108 . Bid, or handsomsly bond, in 3 volnmes with leather back and gilt top, $£ 3, \mathrm{~s}$.

stephlas. The Eidy. By Riccurno Strmexs. Crown $\sin (1,6 \mathrm{~s}$.

STEWART. Heud Immemor. Reminiscences of Legal and Social Life in Edinburgh and London, 1550-1900. By Charles Stewart. With 10 Photogravure Plates. Royal 8ro, 7s. $6 \mathrm{~d}$

STEWART aND CUFE. Practical Nursing. By Isla Stewart, Matron of St Esrtholorrew's Fospital, London; and Herpert E. CUFF, M.D. F.R.C.S., Nedical Silierintendent North-Eastern Fever Hospital, Tottenham, Lenden. Wirh Jjiritrams. In a vols, crown 8vo. Vol. I. Second Edition. 3s. vid. net. Fol. I1., 3s. bu. net. Also in l Volume, 5s. net.

STIRLING.

Our Regiments in South Africa, 1899-1902. Their Record, based on the bespatches. By Jour Strinciag. In 1 vol. demy Svo, 12s. 6d. net.

The Colonials in Surth Africa, 1899-1902. Their Record, based on the lespatches beny oro, 10s. net.

STODDART. John Stuart Plackie: A Biography. By ANnA M. Studdart. POFutAr. EDition, with Portrait. Crown 8vo, 3. 6d.

STORMONTH.

Dictionary the English Language, Pronouncing, Etymoiogicsl, and E Prianatory. By the Rev. JAMEs STORMONTE. Revised by the Rev. P. H. Ynér. Librsry Edition. New snd Chesper Edition, with Surplement. Imperial Sro, haudsomely bound in kaif morocco, 188. net.

Etymologica! and Pronouncing Dictionary of the English Language. Tncluding a very Copious Selection of Sclentiflc Terms. For use in Schools and Colleges, and as \& Book of General Reference. The Pronnnciation carefully reviset by the Rev. H. H. Phelp, M.A. Cantab Sixteenth Editicn, Revised. Crown Sro, pp. 1000. 5s. net.

Handy Dictionary. New Edition, thoroughly Revised. By William Baynk. 16mo, 18. 
STORY. William Wetmore Story and his Friends. From Letters, Diaries, and Recollections. By Hesey Jasles. With 2 Purtraits. In 2 vols. post svo, 24s. net.

SYNGE. The Story of the World. By M. B. Srxes. With Coloured Frontispieres and numerous lllutrations hy F. H. Sravis, A.R.E., and Mals. 2 vols, 2 s. bd. each net.

THEOBALD, A Text-Book of Agricultural Koology. By Fred.

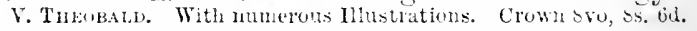

THOMSON. Handy Book of the Flower-Garden. By Darud THOMSON. Crown bvo, 58 .

THOMSON. A Practical Treatise or the Cultivation of the Grape Vine. By Wrlias Thomson, Tweed Vineyards, Ienth Kdition. 8vo, 5s.

THOMSOX. History of the Fife Light Horse. By Colonel

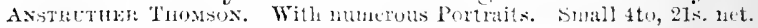

THORPUlix. The Punjab in Peate and War. By S.S. ThurBURs. Demy svo, 12n. bd. liet.

\section{THURSTON.}

The Cirele. By Katmelise Ceal Tiutristox. Fifth Impression. Crown svo, bs.

John Chilcote, M.P. Fourteenth Inpression, crown 8ro, 6s. Cheap Edition, paper corer, eil.

The Mysties. With Mllustrations. C'rown sro, 3s. Gid.

TIELE. Elentents of the Science of Religion. Part I.-Morpholoniral. Part II.-Ontulogiral. Being the Giflord Lintures delivered hefore the

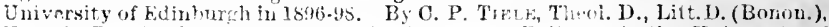
Hon. II.R.A.S., \&c., Professor of the Science of lieligun, in the University of Letich. In 2 pols. pust svo, $7 \mathrm{~s}$. bi. net. egeh.

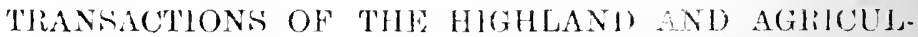
TULAL SOCHETY OF S'OTLAND. PUhlished anmisig, prines.

\section{TIAVERS.}

The Wray of kscalw. A Novel. By Granam Traters (Mar.

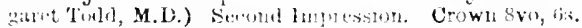

Mon:s Mackesn, Medical Student. A Novel. C'heral Edution,

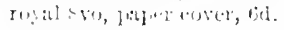

Windyhaugh. Fourih Edition. Crown 8 ro, bs.

Fellow Travellers. Fourth Edition. Crown $8 v 0,6 s$. 


\section{TROTTER.}

A Leader of Light Horse. Life of Hodson of Hodson's Horse. By Captain L. J. TrRotTER, Anthor of 'Life of John Nicholsun, Soldier and Statesman.' With a Portrait and 2 Maps. Demy 8vo, 16s.

TRUSCOTT. The Marriage of Aminta. By L. Parry Truscott. Crown 5 vo, $6 \mathrm{~s}$.

\section{TULLOCH.}

Modern Theories in Philosophy and Religion. By JonN Tulloch, D.D., Prineipal of St Mary's Colle:e in the University of st Andrews, and one of her Majesty's Chaplains in Ordinsry in Scotland. Svo. $15 \mathrm{~s}$.

TWEEDIE. The Arabian Horse: His Country and People. By Major-General W. Twkedik, C.S.I., Bengal Staft Corps; for many years H.B. M.'s Consul.Genersl, Bughdad, and Political Resident for the Government of India in Turkish Arsbia. In one vol. royai 4to, with Seven Coloured Plates and other Illustrations, and a Map of the Country. Price $£ 3,3$ s. net.

VAUGHAN. The Romantic lierolt. By l'rofessor C. E. VAUGHaN. Crown swo, 5s. net.

VOYAGE OF THE "SCOTLA" THE. Being the Record of

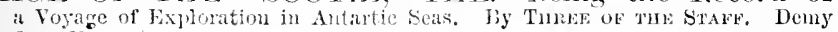
Sro, 21 s. net.

\section{WADDELL.}

Christianity as an Ideal. By Rev. P. Hntely IVAddell, B.D. Crown 8vo, 3s. 6id.

Essays on Faith. Crown 8vo, 3s. 6d.

\section{WARREN'S (SAMUEL) WORKS:--}

Diary of a Late Physician. Cloth, :s. 60. ; hoards, 28.

Ten Thousand A-Year. Cloth, 3a. id.; boards, 2s. $6 \mathrm{~d}$.

Now and Then. The I.ily and tine Bee. Intellectnal and Moral Development of the Prescnt Age, 43, tid.

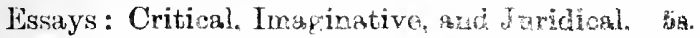

WATSON. The Skipler. Ty Gubate Watsox. C'rown svo, ds.

WATT. By Still Waters. By Macteas WaTt. 1s. 6d. net. Leather, 2s. net.

WENLEY. Aspects of Jessinism. By li. M. Wentey, M.A., D.Sc., D.Phil., Professor of Philosenty in the University of Michigan, U.S.A. Crowa svo, 6s,

\section{WHIBLEY.}

Thackeray. "Modrrn English Writers." By Cinarles

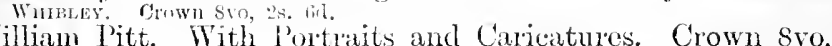
6s. net. 
WHITE.

The Young Gerande. By Edmund White. In 1 vol. crown 8vo, 6s.

Bray of Buckholt. Crown 8vo, 6s.

WILLIAMSSON. Ideals of Ministry. By A. Wallace Williamson, D.D., St Cuth bert's, Edinburgh. Crown svo, 3s. 6d.

WILSON. The Prophets and Prophecy to the Close of the Eighth Century B.C. By the Rev. Alexasier Whisos, M.A., Minister of Y than Wells, Aberdeenshire. Witl lntroductory Pretace by the Rev. Allax Mexzres, D.D., Professor of Biblical Criticism in the University of St Andrews. Fcap. Svo, 1s. net.

WILSON.

Works of Professor Wilson. Edited by his Son-in-Law, Professor FERRIKR. 12 vols. crown $8 \mathrm{vo}, £ 2,8$.

Christopher in his Sporting-Jacket. 2 vols., 88.

Isle of Palms, City of the Plague, and other Poems. 4s.

Lights and Shadows of Scottish Life, and other Tales. $4 \mathrm{~s}$.

Essays, Critical and Imaginative. 4 vols., $18 \mathrm{~s}$.

The Noctes Ambrosianæ. 4 vols., 168.

Homer and his Translators, and the Greek Drama. Crown 3vo, 48.

WORSLEY.

Homer's Odyssey. Translated into English Verse in the Spenserian Stanza. By PHILIP STANHOPE WorsLex, M.A. New and Cheaper Edition. Post 8vo, 78. 6d. net.

Homer's Iliad. Translated by P. S. Worsley and Prof. Conington. 2 vols. erown 8 vo, 218.

\section{WOTHERSPOON.}

Kyrie Eleison ("Lord, have Mercy"). A Manual of Private Prayers. With Notes and Additional Matter. By H. J. Wotherspoon, M.A., of St Oswaid's, Edinburgh. Cloth, red edges, 1s. net; limp leather, 1s. bd. net.

Before and After. Being Part I. of 'Kyrie Eleison.' Cloth, limp, bi. net.

The Second Prayer Book of King Edward the Sixth (1552) along with the Liturgy of Compromise, edited by Rev. G. W. Sputr, D.D. Crown svo, 4 s. net.

YATE. Khurasan and Sistan. By Lieut.-Col. C. E. YATF, C.S.I., C.M.G., F.R.G.S., Indian Staff Corls, Agent te tho Governor-General and Chief Commissioner for Baluchistan, late Agent to the Governor-General of Imlia, and Her Britanic Majesiy's Consul-General for Khurasan and Sistan. With Map and 25 Illustrations, and Portraits. Demy 8vo, 21 .

ZACK.

On Trial. Py Zack. Second Edition. Crown 8vo, $6 \mathrm{~s}$.

Life is Life, and other Tales and Episodes. Second lidition. Crown bvo, Bs. 

UNIVERSITY OF CALIFORNIA AT LOS ANGELES

THE UNIVERSITY LIBRARY

This book is DUE on the last date stamped below

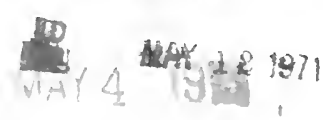


1585 Eraser Foz7 Biogra dia 
